Danielli Cristina Granado

\title{
VARIAÇÕES NICTEMERAIS E SAZONAIS NA ESTRUTURA DA COMUNIDADE FITOPLANCTÔNICA NUM SISTEMA DE LAGOAS DE ESTABILIZAÇÃO (NOVO HORIZONTE, SP)
}

Dissertação apresentada à Escola de Engenharia de São Carlos da Universidade de São Paulo, como parte dos requisitos para obtenção do Título de Mestre em Hidráulica e Saneamento.

Orientadora: Prof ${ }^{a}$ Titular Dra Maria do Carmo Calijuri

São Carlos

2004 


\section{AGRADECIMENTOS}

À Prof ${ }^{a}$ Titular Dra Maria do Carmo Calijuri, exemplo de dedicação, pela valiosa orientação, amizade e por ter contribuído imensamente para o meu amadurecimento como pesquisadora.

À Prof ${ }^{\text {a }}$ Dra Jandira L. B. Talamoni, da UNESP de Bauru, que me apresentou ao incrível mundinho do plâncton, pelo carinho, incentivo, sugestões e por estar sempre presente.

À Prof ${ }^{a}$ Dra Bernadete Varesche, pelas pertinentes contribuições como banca examinadora deste trabalho.

À Prof ${ }^{a}$ Dra Ruth de Gouvêa Duarte, pela amizade, sugestões e pelo auxílio prestado na correção da presente dissertação.

Ao meu pai, Luciano (in memorian) e em especial à minha mãe, Ema, pelo apoio e dedicação incondicional.

Ao meu noivo, Rogério, pela compreensão, companheirismo e pelo auxílio na digitação e formatação deste trabalho.

Aos companheiros do Laboratório BIOTACE: Murilo, André, Ana Luisa, Anna Paola, Patrícia e em especial à Adriana, pelas contribuições relativas à estatística utilizada nest pesquisa.

À doutoranda Patrícia, pelos valiosos ensinamentos com relação às análises químicas e biológicas.

Ao CNPq, pelo auxílio concedido .

Ao Departamento de Hidráulica e Saneamento, pela estrutura fornecida para desenvolvimento deste trabalho; em especial, às secretárias da pós-graduação Pavi e Sá e à recepcionista Rose. 
Aos funcionários do Laboratório de Saneamento da Escola de Engenharia de São Carlos: Paulo, Júlio, Cidinha e à estagiária Juliana, pelo auxílio prestado na realização das análises químicas.

Às pessoas maravilhosas que conheci em São Carlos e que se tornaram mais que amigos: Luciana, Ana Rosa, Denise, Kelly, Wesley, Patrícia, Madalena, Achilles, Sandra, Leonardo e Orlando, pelo carinho e apoio constantes. 
GRANADO, D. C. (2004). Variações nictemerais e sazonais na estrutura da comunidade fitoplanctônica num sistema de lagoas de estabilização (Novo Horizonte, SP). 130 p. Dissertação (Mestrado) - Escola de Engenharia de São Carlos, Universidade de São Paulo, São Carlos, 2004.

\section{RESUMO}

O presente estudo visou caracterizar as variações nictemerais e sazonais na estrutura da comunidade fitoplanctônica do sistema australiano de lagoas de estabilização, localizado no município de Novo Horizonte, SP, por meio de análises de abundância, biomassa, densidade, riqueza e de índices de diversidade, dominância e equidade. Para a realização desse objetivo, as amostras foram coletadas nas lagoas facultativa 1 e facultativa 2 e no efluente final, em quatro épocas: maio/2002 - outono, agosto/2002 - inverno, novembro/2002 - primavera e fevereiro/2003 - verão, a cada seis horas, durante vinte e quatro horas, no total de cinco amostragens (t0, t1, t2, t3 e t4), com início aproximadamente às 9:30 horas; com exceção do efluente final, que foi coletado apenas em t0 e t4. Nestes dois horários também foram coletadas amostras na entrada e na saída da lagoa anaeróbia, para avaliação da eficiência do sistema. Além das variáveis biológicas foram realizadas análises de material em suspensão, nutrientes (nitrogênio total e amoniacal, nitrito, nitrato, fósforo e ortofosfato), oxigênio dissolvido, $\mathrm{pH}$, condutividade elétrica da água, DBO e transparência da água. Foram encontrados organismos pertencentes às classes Chlorophyceae, Cyanophyceae, Euglenophyceae e Bacillariophyceae. Chlorophyceae foi a que mais contribuiu para a riqueza, densidade e biomassa em quase todos os períodos de estudo; mais de $40 \%$ da riqueza foi representada por ela e sua maior densidade foi registrada a $0,7 \mathrm{~m}$ de profundidade na lagoa facultativa 1, em t3, no inverno (875.834,7 org/ml). Entre as espécies dessa classe, a predominante, em todas as épocas de coleta, foi Chlorella vulgaris, considerada dominante no inverno e abundante nas demais estações. Os outros organismos, no entanto, foram somente comuns, ocasionais ou raros. Apesar de ter sido observada estratificação térmica em alguns horários de coleta, principalmente em t1 (por volta das 15:00h), esta não foi duradoura, talvez por se tratar de um sistema raso. Portanto, pode- 
se considerar que o ambiente manteve-se homogêneo em relação à comunidade algal ao longo da coluna de água.

Palavras - Chave: fitoplâncton, lagoas de estabilização, distribuição temporal 
GRANADO, D. C. (2004). Seasonal and diary cycle variations in phytoplankton structure in waste stabilization ponds (Novo Horizonte, SP). 130 p. Dissertation Escola de Engenharia de São Carlos, Universidade de São Paulo, São Carlos, 2004.

\section{ABSTRACT}

The aim of this study were to characterize the seasonal and diary cycle variations of the phytoplankton in waste stabilization ponds from Novo Horizonte, SP. The sample were collected in 1 and 2 facultative ponds and effluent in four times: may/2002 autumn, august/2002 - winter, november/2002 - spring, february/2002- Summer, each six hours in cycle diary. Were analysed abundance, biomass, densith, wealth and diversity index of phytoplankton, chlorophyll $a$, pheopigments, suspended solids, nutrients, dissolvid oxygen, $\mathrm{pH}$, biochimical oxygen demand, electric conductivity and water's transparence. The groups meet were: Chlorophyceae, Cyanophyceae, Euglenophyceae and Bacillariophyceae. Chlorophyceae contribute with bigger wealth, density and biomass; of the kinds this group, Chlorella vulgaris, were prevalent, recognized since dominant in the winter and abundant in others seasons. The other organisms, however, were commons, occasionalls or rares. The environment of ponds remain homogeneous in relation to the algal community.

Keywords: phytoplankton, waste stabilization ponds, temporal variation 


\section{LISTA DE FIGURAS}

Figura 1 - Sistema australiano de lagoas de estabilização de Novo Horizonte, SP.

Figura 2 - Representação do campo do microscópio invertido mostrando como as lâminas foram contadas, a partir da terceira coleta.

Figura 3 - Precipitação mensal $\left(\mathrm{mm}^{3}\right)$ registrada no município de Novo Horizonte, SP entre janeiro de 2002 e fevereiro de 2003.

Figura 4 - Perfis de temperatura $\left({ }^{\circ} \mathrm{C}\right)$ obtidos na lagoa facultativa 1, da ETE de Novo Horizonte, SP, no outono (maio/2002).

Figura 5 - Perfis de temperatura $\left({ }^{\circ} \mathrm{C}\right)$ obtidos na lagoa facultativa 2, da ETE de Novo Horizonte, SP, no outono (maio/2002).

Figura 6 - Perfis de temperatura $\left({ }^{\circ} \mathrm{C}\right)$ obtidos na lagoa facultativa 1 , da ETE de Novo Horizonte, SP, no inverno (agosto/2002).

Figura 7 - Perfis de temperatura $\left({ }^{\circ} \mathrm{C}\right)$ obtidos na lagoa facultativa 2, da ETE de Novo Horizonte, SP, no inverno (agosto/2002).

Figura 8 - Perfis de temperatura $\left({ }^{\circ} \mathrm{C}\right)$ obtidos na lagoa facultativa 1, da ETE de Novo Horizonte, na primavera (novembro/2002).

Figura 9 - Perfis de temperatura $\left({ }^{\circ} \mathrm{C}\right)$ obtidos na lagoa facultativa 2, da ETE de Novo Horizonte, SP, na primavera (novembro/2002).

Figura 10 - Perfis de temperatura $\left({ }^{\circ} \mathrm{C}\right)$ obtidos na lagoa facultativa 1, da ETE de Novo Horizonte, SP, no verão (fevereiro/2003).

Figura 11 - Perfis de temperatura $\left({ }^{\circ} \mathrm{C}\right)$ obtidos na lagoa facultativa 2, da ETE de Novo Horizonte, SP, no verão (fevereiro/2003).

Figura 12 - Temperatura $\left({ }^{\circ} \mathrm{C}\right)$ obtida no efluente final da ETE de Novo Horizonte, SP, nos períodos estudados.

Figura 13 - Perfis de condutividade elétrica da água $(\mathrm{ms} / \mathrm{cm})$ obtidos na lagoa facultativa 1, da ETE de Novo Horizonte, SP, no outono (maio/2002).

Figura 14 - Perfis de condutividade elétrica da água $(\mathrm{ms} / \mathrm{cm})$ obtidos na lagoa facultativa 2, da ETE de Novo Horizonte, SP, no outono (maio/2002).

Figura 15 - Perfis de condutividade elétrica da água $(\mathrm{ms} / \mathrm{cm})$ obtidos na lagoa facultativa 1, da ETE de Novo Horizonte, SP, no inverno (agosto/2002).

Figura 16 - Perfis de condutividade elétrica da água $(\mu \mathrm{s} / \mathrm{cm})$ obtidos na lagoa facultativa 2, da ETE de Novo Horizonte, SP, no inverno (agosto/2002).

Figura 17 - Perfis de condutividade elétrica da água $(\mathrm{ms} / \mathrm{cm})$ obtidos na lagoa facultativa 1, da ETE de Novo Horizonte, SP, na primavera (novembro/2002). 
Figura 18 - Perfis de condutividade elétrica da água $(\mathrm{ms} / \mathrm{cm})$ obtidos na lagoa facultativa 2, da ETE de Novo Horizonte, SP, na primavera (novembro/2002).

Figura 19 - Perfis de condutividade elétrica da água $(\mathrm{ms} / \mathrm{cm})$ obtidos na lagoa facultativa 1, da ETE de Novo Horizonte, SP, no verão (fevereiro/2003).

Figura 20 - Perfis de condutividade elétrica da água $(\mathrm{ms} / \mathrm{cm})$ obtidos na lagoa facultativa 2, da ETE de Novo Horizonte, SP, no verão (fevereiro/2003).

Figura 21 - Condutividade elétrica $(\mathrm{ms} / \mathrm{cm})$ obtida no efluente final da ETE de Novo Horizonte, SP, nos períodos estudados.

Figura 22 - Remoção de sólidos suspensos totais ao longo do tratamento, na ETE de Novo Horizonte, SP, em t0 e t4, nos períodos de estudo.

Figura 23 - Concentrações de DBO (mg/L) ao longo do tratamento na ETE de Novo Horizonte, SP, nas épocas de estudo, em t0 e t4.

Figura 24 - Perfis de oxigênio dissolvido (mg/L) obtidos na lagoa facultativa 1, da ETE de Novo Horizonte, SP, no outono (maio/2002).

Figura 25 - Perfis de oxigênio dissolvido (mg/L) obtidos na lagoa facultativa 2, da ETE de Novo Horizonte, SP, no outono (maio/2002).

Figura 26 - Perfis de oxigênio dissolvido (mg/L) obtidos na lagoa facultativa 1, da ETE de Novo Horizonte, SP, no inverno (agosto/2002).

Figura 27 - Perfis de oxigênio dissolvido (mg/L) obtidos na lagoa facultativa 2, da ETE de Novo Horizonte, SP, no inverno (agosto/2002).

Figura 28 - Perfis de oxigênio dissolvido (mg/L) obtidos na lagoa facultativa 1, da ETE de Novo Horizonte, SP, na primavera (novembro/2002).

Figura 29 - Perfis de oxigênio dissolvido (mg/L) obtidos na lagoa facultativa 2, da ETE de Novo Horizonte, SP, na primavera (novembro/2002).

Figura 30 - Perfis de oxigênio dissolvido (mg/L) obtidos na lagoa facultativa 1, da ETE de Novo Horizonte, SP, no verão (fevereiro/2003).

Figura 31 - Perfis de oxigênio dissolvido (mg/L) obtidos na lagoa facultativa 2, da ETE de Novo Horizonte, SP, no verão (fevereiro/2003).

Figura 32 - Concentrações de oxigênio dissolvido (mg/L) obtidas no efluente final da ETE de Novo Horizonte, SP, nos períodos estudados.

Figura 33 - Perfis de pH obtidos na lagoa facultativa 1, da ETE de Novo Horizonte, SP, no outono (maio/2002).

Figura 34 - Perfis de $\mathrm{pH}$ obtidos na lagoa facultativa 2, da ETE de Novo Horizonte, SP, no outono (maio/2002).

Figura 35 - Perfis de pH obtidos na lagoa facultativa 1, da ETE de Novo Horizonte, SP, no inverno (agosto/2002).

Figura 36 - Perfis de $\mathrm{pH}$ obtidos na lagoa facultativa 2, da ETE de Novo Horizonte, SP, no inverno (agosto/2002). 
Figura 37 - Perfis de $\mathrm{pH}$ obtidos na lagoa facultativa 1, da ETE de Novo Horizonte, SP, na primavera (novembro/2002).

Figura 38 - Perfis de $\mathrm{pH}$ obtidos na lagoa facultativa 2, da ETE de Novo Horizonte, SP, na primavera (novembro/2002).

Figura 39 - Perfis de pH obtidos na lagoa facultativa 1, da ETE de Novo Horizonte, SP, no verão (fevereiro/2003).

Figura 40 - Perfis de pH obtidos na lagoa facultativa 2, da ETE de Novo Horizonte, SP, no verão (fevereiro/2003).

Figura 41 - Valores de pH obtidos no efluente final da ETE de Novo Horizonte, $\mathrm{SP}$, nos períodos estudados.

Figura 42 - Densidade das classes fitoplanctônicas encontradas nas lagoas facultativa 1 e facultativa 2 da ETE de Novo Horizonte, SP, no outono (maio/2002).

Figura 43 - Densidade das classes fitoplanctônicas encontradas nas lagoas facultativa 1 e facultativa 2 da ETE de Novo Horizonte, SP, no inverno (agosto/2002).

Figura 44 - Densidade das classes fitoplanctônicas encontradas nas lagoas facultativa 1 e facultativa 2 da ETE de Novo Horizonte, SP, na primavera (novembro/2002).

Figura 45 - Densidade das classes fitoplanctônicas encontradas nas lagoas facultativa 1 e facultativa 2 da ETE de Novo Horizonte, SP, no verão (fevereiro/2003).

Figura 46 - Densidade das classes fitoplanctônicas encontradas no efluente final da ETE de Novo Horizonte, SP, nos períodos de estudo.

Figura 47 - Índices de diversidade encontrados nos períodos de estudo, nas lagoas facultativa 1 e facultativa 2 da ETE de Novo Horizonte, SP.

Figura 48 - Índices de dominância obtidos nos períodos amostrados, nas lagoas facultativa 1 e facultativa 2 da ETE de Novo Horizonte, SP.

Figura 49 - Valores de equidade encontrados nos períodos estudados nas lagoas facultativa 1 e facultativa 2 da ETE de Novo Horizonte, SP.

Figura 50 - Índices de riqueza obtidos nas épocas amostradas nas lagoas facultativa 1 e facultativa 2 da ETE de Novo Horizonte, SP.

Figura 51 - Biovolume das espécies mais representativas das lagoas facultativa 1 e facultativa 2 da ETE de Novo Horizonte, SP, no outono (maio/2002).

Figura 52 - Biovolume das espécies mais representativas das lagoas facultativa 1 e facultativa 2 da ETE de Novo Horizonte, SP, no inverno (agosto/2002).

Figura 53 - Biovolume das espécies mais representativas, das lagoas facultativa 1 e facultativa 2 da ETE de Novo Horizonte, SP, na primavera (novembro/2002). 
Figura 54 - Biovolume das espécies mais representativas, das lagoas facultativa 1 e facultativa 2 da ETE de Novo Horizonte, SP, no verão (fevereiro, 2003).

Figura 55 - Variação na concentração de clorofila a ( $\mu \mathrm{g} / \mathrm{L})$, ao longo de 24h, nas lagoas facultativa 1 e facultativa 2 da ETE de Novo Horizonte, SP, no outono (maio/2002).

Figura 56 - Variação na concentração de clorofila a ( $\mu \mathrm{g} / \mathrm{L})$, ao longo de 24h, nas lagoas facultativa 1 e facultativa 2 da ETE de Novo Horizonte, SP, no inverno (agosto/2002).

Figura 57 - Variação na concentração de clorofila a ( $\mu \mathrm{g} / \mathrm{L})$, ao longo de 24h, nas lagoas facultativa 1 e facultativa 2 da ETE de Novo Horizonte, SP, na primavera (novembro/2002).

Figura 58 - Variação na concentração de clorofila a ( $\mu \mathrm{g} / \mathrm{L})$, ao longo de 24h, nas lagoas facultativa 1 e facultativa 2 da ETE de Novo Horizonte, SP, no verão (fevereiro/2003).

Figura 59 - Variação na concentração de feofitina ( $\mu \mathrm{g} / \mathrm{L})$, ao longo de 24h, nas lagoas facultativa 1 e facultativa 2 da ETE de Novo Horizonte, SP, no outono (maio/2002).

Figura 60 - Variação na concentração de feofitina ( $\mu \mathrm{g} / \mathrm{L})$, ao longo de 24h, nas lagoas facultativa 1 e facultativa 2 da ETE de Novo Horizonte, SP, no inverno (agosto/2002).

Figura 61 - Variação na concentração de feofitina ( $\mu \mathrm{g} / \mathrm{L})$, ao longo de 24h, nas lagoas facultativa 1 e facultativa 2 da ETE de Novo Horizonte, SP, na primavera (novembro/2002).

Figura 62- Variação na concentração de feofitina ( $\mu \mathrm{g} / \mathrm{L})$, ao longo de $24 \mathrm{~h}$, nas lagoas facultativa 1 e facultativa 2 da ETE de Novo Horizonte, SP, no verão (fevereiro/2003). 


\section{LISTA DE QUADROS E TABELAS}

Quadro 1 - Características das lagoas de estabilização do sistema australiano de Novo Horizonte, SP, em agosto de 2002.

Tabela 1 - Profundidades de desaparecimento do disco de Secchi (Zds) e da zona eufótica (Zeu) e coeficiente de atenuação do contraste vertical (K), nos períodos e estações amostrados, na ETE de Novo Horizonte, SP.

Tabela 2 - Concentrações (mg/L) de sólidos suspensos, totais (SST), inorgânicos (SSI) e orgânicos (SSO), nas estações de coleta da ETE de Novo Horizonte, SP, no outono (maio/2002) e no inverno (agosto/2002).

Tabela 3 - Concentrações (mg/L) de sólidos suspensos, totais (SST), inorgânicos (SSI) e orgânicos (SSO), nas estações de coleta da ETE de Novo Horizonte, SP, na primavera (novembro/2002) e no verão (fevereiro/2003).

Tabela 4 - Concentrações (mg/L) dos nutrientes totais, fósforo (PT) e nitrogênio (NT) e dos nutrientes dissolvidos, nitrito $\left(\mathrm{NO}_{2}\right)$, nitrato $\left(\mathrm{NO}_{3}\right)$, nitrogênio amoniacal (N-amon.) e ortofosfato $\left(\mathrm{PO}_{4}\right)$, nas estações de coleta da ETE de Novo Horizonte, SP, no outono (maio/2002).

Tabela 5 - Concentrações (mg/L) dos nutrientes totais, fósforo (PT) e nitrogênio (NT) e dos nutrientes dissolvidos, nitrito $\left(\mathrm{NO}_{2}\right)$, nitrato $\left(\mathrm{NO}_{3}\right)$, nitrogênio amoniacal (N-amon.) e ortofosfato $\left(\mathrm{PO}_{4}\right)$, nas estações de coleta da ETE de Novo Horizonte, SP, no inverno (agosto/2002).

Tabela 6 - Concentrações (mg/L) dos nutrientes totais, fósforo (PT) e nitrogênio (NT) e dos nutrientes dissolvidos, nitrito $\left(\mathrm{NO}_{2}\right)$, nitrato $\left(\mathrm{NO}_{3}\right)$, nitrogênio amoniacal (N-amon.) e ortofosfato $\left(\mathrm{PO}_{4}\right)$, nas estações de coleta da ETE de Novo Horizonte, SP, na primavera (novembro/2002).

Tabela 7 - Concentrações (mg/L) dos nutrientes totais, fósforo (PT) e nitrogênio (NT) e dos nutrientes dissolvidos, nitrito $\left(\mathrm{NO}_{2}\right)$, nitrato $\left(\mathrm{NO}_{3}\right)$, nitrogênio amoniacal ( $\mathrm{N}$-amon.) e ortofosfato $\left(\mathrm{PO}_{4}\right)$, nas estações de coleta da ETE de Novo Horizonte, SP, no verão (fevereiro/2003).

Tabela 8 - Porcentagem de contribuição média das classes fitoplanctônicas na ETE de Novo Horizonte, SP, por período de estudo.

Tabela 9 - Abundância relativa média dos organismos fitoplanctônicos encontrados nas lagoas facultativa 1 e facultativa 2 da ETE de Novo Horizonte, SP, no outono (maio/2002). 
Tabela 10 - Abundância relativa média dos organismos fitoplanctônicos encontrados nas lagoas facultativa 1 e facultativa 2 da ETE de Novo Horizonte, SP, no inverno (agosto/2002).

Tabela 11 - Abundância relativa média dos organismos fitoplanctônicos encontrados nas lagoas facultativa 1 e facultativa 2 da ETE de Novo Horizonte, SP, na primavera (novembro/2002).

Tabela 12 - Abundância relativa média dos organismos fitoplanctônicos encontrados nas lagoas facultativa 1 e facultativa 2 da ETE de Novo Horizonte, SP, no verão (fevereiro/2003).

Tabela 13 - Dimensões médias, formas geométricas e volume celular médio dos organismos dominantes, abundantes e comuns presentes nas lagoas facultativa 1 e facultativa 2 da ETE de Novo Horizonte, SP, no período de estudo. 


\section{LISTA DE ABREVIATURAS E SIGLAS}

Cond.: condutividade

CV: coeficiente de variação

DBO: demanda bioquímica de oxigênio

Dens.: densidade fitoplanctônica

Dv P: desvio padrão

ETE: estação de tratamento de esgoto

E1: ponto de coleta referente à entrada da lagoa anaeróbia

E2: ponto de coleta referente à saída da lagoa anaeróbia

E3: referente à lagoa facultativa 1

E3S: ponto de coleta referente à superfície da lagoa facultativa 1

E3M: ponto de coleta referente à $0,7 \mathrm{~m}$ de profundidade da lagoa facultativa 1

E3F: ponto de coleta referente à 1,5 m de profundidade da lagoa facultativa 1

E4: referente à lagoa facultativa 2

E4S: ponto de coleta referente à superfície da lagoa facultativa 2

E4M: ponto de coleta referente à 0,7 m de profundidade da lagoa facultativa 2

E4F: ponto de coleta referente à 1,5 m de profundidade da lagoa facultativa 2

E5: referente ao efluente que sai da lagoa facultativa 2 em direção ao córrego Três Pontos 
Inv.: inverno

LF1: lagoa facultativa 1

LF2: lagoa facultativa 2

NT: nitrogênio total

Out.: outono

Prim.: primavera

Prof.: profundidade

PT: fósforo total

SS: sólidos suspensos

$\mathbf{T}\left({ }^{\circ} \mathbf{C}\right)$ : temperatura

t0: referente ao primeiro horário de coleta, aproximadamente às 9:30h

t1: referente ao segundo horário de coleta, aproximadamente às 15:30h

t2: referente ao terceiro horário de coleta, aproximadamente às 21:30h

t3: referente ao quarto horário de coleta, aproximadamente às 03:30h

t4: referente ao último horário de coleta, aproximadamente às 9:30h do dia seguinte

Ver.: verão 


\section{SUMÁRIO}

1 INTRODUÇÃO

2 OBJETIVOS

3 REVISÃO BIBLIOGRÁFICA

3.1 Sistema de Lagoas de Estabilização

3.2 Algas em Lagoas de Estabilização

3.3 Mudanças na Comunidade Fitoplanctônica

4 CARACTERIZAÇÃO DA ÁREA DE ESTUDO

5 MATERIAIS E MÉTODOS

5.1 Metodologia de amostragem

5.2 Variável Climatológica

5.2.1 Pluviosidade

5.3 Variáveis Físicas

5.3.1 Temperatura e Condutividade Elétrica

5.3.2 Transparência da Água, Extensão da Zona Eufótica e Coeficiente de Atenuação do Contraste Vertical

5.3.3 Material em Suspensão

5.4 Variáveis Químicas

5.4.1 DBO

5.4.2 Oxigênio Dissolvido e Potencial Hidrogeniônico

5.4.3 Nutrientes Inorgânicos Dissolvidos

5.4.3.1 Nitrogênio Amoniacal

5.4.3.2 Nitrito e Nitrato

5.4.3.3 Ortofosfato

5.4.4 Nutrientes Totais

5.4.4.1 Nitrogênio Total

5.4.4.2 Fósforo Total

5.5 Variáveis Biológicas 
5.5.1.3 Porcentagem de Contribuição das Classes 26

5.5.1.4 Abundância Relativa

5.5.1.5 Índices de Diversidade de Espécies, Dominância, Equidade e Riqueza $\quad 27$

5.5.1.6 Biovolume 28

5.5.1.7 Estrutura de Tamanho dos Organismos Pertencentes a Comunidade 28

$\begin{array}{ll}\text { 5.5.2 Clorofila a e feofitina } & 29\end{array}$

6 RESULTADOS 30

6.1 Variável Climatológica 30

6.1.1 Pluviosidade 30

6.2 Variáveis Físicas da Água 30

6.2.1 Temperatura 30

6.2.2 Condutividade Elétrica 35

6.2.3 Transparência da Água, Extensão da Zona Eufótica e Coeficiente de Atenuação do Contraste Vertical

6.2.4 Material em Suspensão $\quad 42$

6.3 Variáveis Químicas da Água 45

6.3.1 DBO 45

6.3.2 Oxigênio Dissolvido 46

6.3.3 Potencial Hidrogeniônico 52

6.3.4 Nutrientes Totais e Nutrientes Inorgânicos Dissolvidos 57

6.4 Variáveis Biológicas $\quad 64$

6.4.1 Comunidade Fitoplanctônica 64

6.4.1.1 Riqueza $\quad 64$

6.4.1.2 Densidade Fitoplanctônica 65

6.4.1.3 Porcentagem de Contribuição das Classes $\quad 70$

6.4.1.4 Abundância Relativa 71

6.4.1.5 Índices de Diversidade de Espécies, Dominância, Equidade e Riqueza 75

6.4.1.6 Biovolume 78

6.4.1.7 Estrutura de Tamanho dos Organismos Pertencentes a Comunidade 82

6.4.2 Clorofila a e Feofitina 83

$\begin{array}{ll}7 \text { DISCUSSÃO } & 89\end{array}$ 
7.1 Variáveis Físico - Químicas

7.2 Variáveis Biológicas

8 CONCLUSÕES

9 REFERÊNCIAS BIBLIOGRÁFICAS

APÊNDICES 


\section{INTRODUÇÃO}

A crescente preocupação da sociedade com relação à água reflete a séria escassez desta em âmbito mundial. Embora abundante, esse recurso apresenta-se desigualmente distribuído no planeta e associado ao acelerado crescimento demográfico e ao conseqüente aumento de produção - que demandam grandes quantidades de água para abastecimento doméstico e industrial, além das utilizações para lazer e agricultura - tornam essenciais a utilização racional e a proteção dos recursos hídricos.

Somadas ao elevado consumo, as ações antrópicas causam ainda drásticas modificações nos ambientes aquáticos, especialmente devido às diferentes formas de poluição, oriundas de efluentes domésticos e industriais. Neste âmbito, fica evidente a necessidade de eliminar ou diminuir os prejuízos decorrentes dessa poluição, o que pode ser alcançado através do tratamento de águas residuais, considerado como reprodução da autodepuração que ocorre na natureza, na qual a estabilização da matéria orgânica é realizada, principalmente, pela ação de microrganismos. Desta forma, o conhecimento da identidade desses organismos e de seus papéis, em cada etapa do tratamento, são indispensáveis ao estudo do funcionamento desses sistemas.

As algas estão relacionadas à poluição dos sistemas aquáticos de diversas maneiras. Certas espécies são capazes de florescer em águas poluídas com altas cargas orgânicas, desenvolvendo importante função na autopurificação do corpo de água. Além disso, podem também ser usadas como indicadoras de poluição (PALMER, 1980).

De acordo com Mendonça (2000), quase a totalidade dos projetos de estações de tratamento de esgoto doméstico são baseados em processos biológicos. Entre esses métodos, destacam-se as lagoas de estabilização, que se beneficiam de fatores abióticos e bióticos como radiação solar, ação dos ventos, temperatura e fotossíntese para produzir efluentes líquidos com qualidade que alcança os padrões de emissão estabelecidos na legislação de grande número de países.

Mas é principalmente na relação mutualística entre a comunidade fitoplanctônica e a bacteriana que repousa o princípio do tratamento biológico nas lagoas facultativa e de maturação (PEARSON, 1996). As algas se apresentam como um dos grupos mais diversificados entre os microrganismos presentes nessas lagoas e, devido à produção de oxigênio, são responsáveis pela continuidade dos processos aeróbios; além disso, ainda removem nutrientes como nitrogênio, fósforo e carbono para suprir suas necessidades nutricionais (SENNA, 1979; PALMER, 1980; VOLTOLINA, 1998; MASSERET et al., 
2000). Mas, embora vitais ao processo de tratamento, as algas também podem causar problemas devido ao seu crescimento excessivo, ocasionando aumento da DBO e, conseqüentemente, elevação da demanda de oxigênio no corpo de água receptor (KONIG, 1984; MASSERET et al, 2000.).

Contudo, trabalhos realizados por diversos autores, entre eles Konig (op cit.), mostram a grande variação na qualidade dos efluentes em um ciclo de 24 horas, o que evidencia a necessidade de estudos nictemerais, pois amostras pontuais podem não representar o valor médio do período. Além disso, as oscilações periódicas, devidas especialmente, aos ciclos de claro/escuro, afetam significativamente as atividades dos microrganismos e a organização da comunidade algal na coluna de água.

Portanto, o presente estudo se propôs a identificar os organismos fitoplanctônicos que participam do processo de autodepuração de águas residuais no sistema de lagoas de estabilização situado no município de Novo Horizonte, SP; analisar as variações desta comunidade e dos fatores abióticos ao longo de 24h; e também conhecer a substituição de espécies que ocorre sazonalmente naquele ambiente. 


\section{OBJETIVOS}

\subsection{Geral}

O objetivo deste estudo foi caracterizar a comunidade fitoplanctônica do sistema australiano de lagoas de estabilização, localizado no município de Novo Horizonte, SP, por meio de análises de variações nictemerais e sazonais.

\subsection{Específicos}

Os objetivos específicos foram:

- Identificar as espécies fitoplanctônicas que compõem a flora das lagoas facultativas;

Analisar as mudanças temporais (nictemerais e sazonais) na estrutura desta comunidade, por meio do reconhecimento de espécies dominantes, abundantes, comuns e raras; da riqueza; da equidade e da diversidade de espécies;

* Verificar as mudanças espaciais (verticais), que ocorrem ao longo de vinte e quatro horas, através de dados de densidade fitoplanctônica;

* Determinar a contribuição da biomassa algal pelo biovolume. 


\section{REVISÃO BIBLIOGRÁFICA}

\subsection{Sistema de Lagoas de Estabilização}

Há muito são conhecidos os prejuízos que as águas residuárias acarretam ao meio ambiente, especialmente aos recursos hídricos. Descritos por vários pesquisadores como a mais antiga e relevante forma de poluição antrópica, os esgotos podem ser definidos como resultado de despejos provenientes dos diversos usos da água; o doméstico é composto por 99,9\% de água e apenas 0,1\% de sólidos suspensos, coloidais e dissolvidos (MENDONÇA, 1990; VON SPERLING, 1996a).

Atualmente, são utilizados inúmeros sistemas para tratamento de águas residuais, com vistas a diminuir os impactos que esses despejos provocam nas coleções hídricas. Entre os métodos freqüentemente utilizados em países tropicais estão as lagoas aeradas, os reatores anaeróbios e as lagoas de estabilização, que são considerados um dos mais simples sistemas para tratamento de esgoto doméstico (MENDONÇA, 2000).

Muitos autores discutem as vantagens e desvantagens para adoção de lagoas de estabilização como método de recuperação de águas residuárias. Entre os benefícios estão a simplicidade na construção, operação e manutenção do sistema; seu baixo custo operacional; elevada qualidade microbiológica do efluente final e a grande eficiência na transformação de matéria orgânica em biomassa algal (WRIGLEY e TOERIEN, 1990; KELLNER e PIRES, 1998; MASSERET et al., 2000). Os inconvenientes são, principalmente, a dependência de fatores climáticos e a necessidade de grandes áreas, que são fatores de baixa relevância em países como o Brasil, onde o clima é tropical e a disponibilidade de terrenos a baixo custo nas periferias das cidades é grande (KELLNER e PIRES, op cit.).

Segundo Kellner e Pires (op cit.), as lagoas de estabilização foram introduzidas no Brasil há 36 anos, pelo engenheiro Victoretti, que construiu um sistema em São José dos Campos. No entanto, há relatos do uso desse tipo de sistema desde 1901, em San Antonio, Texas nos Estados Unidos, onde foi construída uma lagoa para armazenar esgotos com a finalidade de reuso da água para irrigação. Em 1924, também nos Estados Unidos, em Santa Rosa - Califórnia, os esgotos foram lançados sobre um leito natural de pedras; em pouco tempo formou-se uma lagoa de $90 \mathrm{~cm}$ de profundidade que não apresentava odores desagradáveis. Na Austrália, na década de 40, iniciaram-se pesquisas relacionadas à depuração de despejos em lagoas de estabilização. Foi somente 
em 1948, em Maddok, Dakota do Norte, Estados Unidos, que foi construída a primeira instalação americana oficial, projetada para a estabilização de águas residuárias.

As lagoas de estabilização podem ser classificadas em: sistema americano, nas quais, depois de ser clarificado, o esgoto é lançado em lagoas rasas, de condições aeróbias; e sistema australiano, no qual o esgoto bruto é diretamente despejado em uma lagoa de condições anaeróbias.

Segundo Von Sperling (1996b), há diversas variantes desse tipo de sistema, com diferentes níveis de simplicidade operacional e requisitos de área. Entre os mais comumente usados estão as lagoas facultativas, os sistemas de lagoas anaeróbias seguidas por lagoas facultativas e as lagoas aeradas, de mistura parcial ou completa, seguidas por lagoas de decantação.

A escolha do tipo de sistema, além de levar em conta a disponibilidade de área, deve ter em vista o nível de tratamento que deve ser alcançado, em função do uso ao qual se destina. Geralmente, os processos de tratamento são classificados através dos seguintes níveis: tratamento preliminar, que visa a remoção de sólidos grosseiros; tratamento primário, que tem como objetivo remover sólidos sedimentáveis e parte da matéria orgânica; tratamento secundário, que tem como principal função a remoção da matéria orgânica e nutrientes (nitrogênio e fósforo); e tratamento terciário, que visa remover poluentes específicos, como compostos não-biodegradáveis, patógenos, metais pesados, entre outros (VON SPERLING, 1996a).

O sistema descrito a seguir é análogo ao ecossistema universo desta pesquisa e compreende todas as fases de tratamento, da etapa preliminar à terciária.

Usualmente, o esgoto que chega à estação de tratamento passa por um gradeamento (tratamento preliminar) e segue para uma lagoa anaeróbia (tratamento primário), onde bactérias acidogênicas e metanogênicas promovem a biodegradação. As bactérias acidogênicas convertem compostos orgânicos complexos em moléculas mais simples, principalmente ácido acético, que servem de substrato para a ação das arqueas metanogênicas que o transformam em metano e dióxido de carbono. A eficiência de remoção de DBO nessas lagoas alcança em torno de 50\% a 60\%.

A seguir, a água residual é transferida para uma lagoa facultativa (tratamento secundário), local em que a DBO remanescente é removida entre 60\% a 99\%. Esta lagoa apresenta uma zona aeróbia, uma facultativa e uma anaeróbia. A parte aeróbia encontra-se na camada superficial, na faixa de maior intensidade luminosa, onde as bactérias aeróbias convertem a matéria orgânica em dióxido de carbono, amônia e 
fosfatos utilizados pelas algas na fotossíntese que, por sua vez, têm a importante função de fornecer oxigênio ao ecossistema. Durante as horas do dia, as algas também respiram e oxidam parte da matéria orgânica produzida, liberando assim energia para seu crescimento, reprodução e locomoção. No entanto, o balanço entre produção e consumo (respiração) de oxigênio favorece amplamente o primeiro, pois há evidências que as algas produzem cerca de quinze vezes mais oxigênio do que consomem, com saldo positivo para o sistema. Abaixo da camada superficial, está a zona facultativa e sob ela a zona anaeróbia, constituída pelo lodo de fundo, o qual é lentamente convertido em dióxido de carbono, água, metano e outros. A profundidade das zonas aeróbia e anaeróbia varia durante as vinte e quatro horas do dia, em função da variabilidade de ocorrência da fotossíntese durante esse período. Esta variação também ocorre de acordo com as condições de carga da lagoa.

A lagoa de maturação recebe um afluente com DBO praticamente estabilizada e com oxigênio dissolvido em toda a massa liquida; sua principal função é remover nitrogênio, fósforo e organismos patogênicos, devido aos seus altos valores de $\mathrm{pH}$ (acima de 8,5) e à extensa zona eufótica, que permite a penetração de raios ultravioletas até o fundo da lagoa, permitindo elevada eficiência na remoção de coliformes (cerca de 99\%), além da eliminação de cistos e ovos de helmintos (VON SPERLING,0 1996b; KELLNER e PIRES, 1998; MENDONÇA, 2000). 


\subsection{Algas em Lagoas de Estabilização}

Apesar da função das algas no processo de tratamento de águas residuais em lagoas de estabilização ser considerado fundamental, poucos são os estudos de levantamento taxonômico do fitoplâncton nesses ambientes e menos freqüentes, ainda, são os que abordam a estrutura dessa comunidade.

Palmer (1969, 1980), com dados de muitos autores, listou gêneros e espécies fitoplanctônicas tolerantes à poluição, freqüentemente encontrados em ambientes com altas cargas orgânicas, incluídas as lagoas de estabilização; e concluiu que os resíduos orgânicos podem ter maior influência na composição desses organismos do que fatores ambientais como temperatura, intensidade luminosa, $\mathrm{pH}$, oxigênio dissolvido e tamanho do corpo de água.

Branco (1975) e também Silva e Mara (1979) descreveram os principais gêneros de algas encontradas em lagoas de estabilização; os últimos autores estudaram lagoas no nordeste do Brasil.

Em 1979, Senna analisou as cianobactérias de uma lagoa de estabilização da cidade de São Carlos e desenvolveu uma chave para identificação dos organismos encontrados nesses ambientes. O autor comentou a nítida importância do conhecimento desses microrganismos para compreensão do desempenho desses sistemas e salientou a necessidade de estudos sazonais aliados a alguns parâmetros físico-químicos, com o propósito de relacionar o nível de poluição à composição de espécies.

Konig (1984), em estudo realizado em lagoas de estabilização no nordeste do Brasil, analisou a estrutura da comunidade fitoplanctônica por meio de variações diurnas. Seus resultados mostraram que algumas variáveis medidas, como sólidos suspensos, DBO e níveis de oxigênio dissolvido, apresentavam flutuações consideráveis durante vinte e quatro horas, evidenciando que amostras pontuais coletadas em horas pré-estabelecidas podem não representar as variações diárias da qualidade do efluente. O estudo constatou segregação espacial máxima das algas entre às doze e às quatorze horas e homogeneização completa da coluna de água às dezoito horas; mas, não foi observada estratificação na lagoa de maturação. Segundo a autora, baixas intensidades luminosas induzem a fototaxia das algas (pelo menos das flageladas), o que explicaria a distribuição uniforme na coluna de água ao amanhecer; enquanto que altas intensidades resultam em resposta negativa, com movimento decrescente para longe da superfície. 
Algumas espécies de Euglenophyceae são capazes de sobreviver e crescer em total escuridão, alimentando-se de compostos orgânicos. Há também evidências de que baixas taxas de carbono orgânico sejam assimilados no escuro por Chlorella. Isto seria uma vantagem para essas algas, especialmente em ambientes como as lagoas de estabilização, nas quais a profundidade da zona eufótica é muito pequena (restrita à superfície) (KONIG, 1984).

Em 1988, Ferreira analisou a distribuição espaço-temporal da comunidade fitoplanctônica de um sistema de lagoas de estabilização localizado em Brasília, DF e encontrou vinte e sete gêneros e quarenta e sete espécies. Seus resultados mostraram que as populações algais distribuíam-se homogeneamente por toda a lagoa, bem como pela coluna de água. $\mathrm{O}$ autor relacionou esse fato à turbulência gerada pela ação dos ventos e à constante entrada do afluente.

Wrigley e Toerien (1990) estudaram alguns aspectos limnológicos, entre eles a dominância algal, de pequenas lagoas de estabilização de Bloemfontein, na Austrália e encontraram quatorze gêneros dominantes que se alternaram durante o período de estudo. Entre os principais estavam os flagelados Euglena, Chlamydomonas e Lepocinclis, além de Micractinium, também abundante.

Reynolds (1998) relacionou os principais gêneros fitoplanctônicos ao grau de trofia dos ambientes, a partir de sistemas oligotróficos até hipereutróficos; nesses últimos se enquadraram Euglena, Phacus e Lepocinclis.

Os organismos comumente encontrados em lagoas de estabilização, além das euglenofíceas, são: as cianofíceas, Oscillatoria e Spirulina; as clorofíceas, Chlamydomonas, Chlorella, Chlorogonion, Micractinium, Pyrobotrys e Scenedesmus; e as diatomáceas, Navícula e Nitzchia (BRANCO, 1975 e 1986; SILVA e MARA, 1979; KONIG, op cit.; WRIGLEY e TOERIEN, op cit.; PEARSON, 1996). Kellner e Pires (1998) citam ainda os gêneros Ankistrodesmus, Crucigenia, Dictyosphaerium, Golenkinia, Oocystis, Sphaerocystis e Tetraedron (clorofíceas); Anabaena, Microcystis, Synechococcus e Synechocystis (cianofíceas); Trachelomonas (euglenofícea); e Cyclotella e Synedra (diatomáceas). 


\subsection{Mudanças na Comunidade Fitoplanctônica}

O fluxo de energia em sistemas aquáticos é determinado principalmente pelas comunidades fitoplanctônica e de macrófitas aquáticas; sendo o fitoplâncton responsável pela continuidade dos processos vitais nos demais níveis tróficos das cadeias de herbívoria e detritívora das regiões limnéticas (HUSZAR, SILVA e ESTEVES, 1990).

A comunidade fitoplanctônica é constituída por grande número de espécies que possuem formas e estratégias de sobrevivência distintas, as quais são capazes de adaptar suas funções metabólicas às diferentes mudanças ambientais (CALIJURI, 1988; GIANI e LEONARDO, 1988). Assim, a dinâmica do fitoplâncton pode ser entendida como controlada por uma combinação de processos hidrodinâmicos que atuam nas mais variadas escalas espaciais e temporais (CALIJURI, op cit).

De acordo com Harris (1986), o comportamento dos organismos fitoplanctônicos na coluna de água é influenciado por fatores endógenos, como capacidade de flutuabilidade, velocidade de afundamento e migração vertical e por interferências exógenas, como estratificações térmica e química da água e mistura pelo vento.

Segundo Reynolds (1984), as algas fitoplanctônicas podem ser divididas em três grupos, de acordo com sua distribuição vertical: no primeiro, estariam as células mais pesadas e desprovidas de movimentos, cuja tendência é sedimentar, como Melosira e Asterionella; o segundo grupo incluiria organismos com capacidade de regulagem da flutuação, através de organelas como vacúolos gasosos, como Microcystis e Anabaena; e ao terceiro grupo pertenceriam as algas com densidade similar à da água, como Ankyra, além daquelas capazes de migrar na coluna de água pela ação de flagelos, como as euglenofíceas.

A distribuição vertical do fitoplâncton sofre variações ao longo do dia (ciclo de 24 horas) e das estações do ano. Essas variações são associadas, principalmente, a padrões de circulação da massa de água, intensidade luminosa, disponibilidade de nutrientes e efeitos de predação (GIANI e LEONARDO, op cit.).

A composição de espécies e a abundância relativa das populações fitoplanctônicas também sofrem alterações que acompanham os ciclos diário e sazonal. Muitos autores destacam que essas variáveis são dependentes da qualidade da água, mais especificamente da concentração de nutrientes e da instabilidade física da coluna 
de água (REYNOLDS, 1984; HARRIS, 1986; CANOVAS et al., 1996; CALIJURI, 1999).

As mudanças que acompanham o ciclo sazonal recebem a denominação de sucessão ecológica, cuja definição é amplamente discutida por diversos autores (HUSZAR e REYNOLDS, 1997).

Segundo Garcia de Emiliani (1993), a característica marcante da sucessão ecológica é a mudança na dominância de pequenos para grandes indivíduos. Organismos menores apresentam altas taxas de produção/biomassa (P/B) e processam mais rapidamente energia e nutrientes, são denominadas $r$ - estrategistas, as quais dominam os estágios iniciais do processo. Indivíduos maiores, por sua vez, apresentam baixas taxas de P/B e necessitam de menos energia para manutenção de biomassa semelhante, são as espécies chamadas de k - estrategistas, que dominam ecossistemas mais maduros, nos quais a ciclagem de nutrientes é eficiente e a diversidade e estabilidade de espécies é alta (REYNOLDS, 1984).

A sucessão de espécies tem sido muito bem estudada em lagos do hemisfério norte, de clima temperado, tendo início no período de mistura que ocorre na primavera, com aumento da densidade de organismos, a qual atinge o pico na metade do verão e diminui no inverno até alcançar seu valor mínimo.

Para Sommer (1989), nas comunidades fitoplanctônicas a sucessão é iniciada principalmente por eventos físicos, como temperatura da água, profundidade de mistura, média diária de luz, fotoperíodo e coeficiente de extinção. Essas alterações também podem ser consideradas como perturbações ou distúrbios, e chegam a estacionar o progresso sussecional ou retrocedê-lo a um estágio anterior; e podem, ainda, destruir a estrutura existente e iniciar nova mudança.

Reynolds (1988a) salienta que o período e a seqüência dessas sucessões são freqüentes e extensivamente repetidas ano a ano ou algumas vezes, em curtos ciclos ao longo do ano. $\mathrm{O}$ autor considera que essas mudanças podem ser reconhecidas por serem conseqüências acumulativas de diferentes respostas individuais das espécies para os eventos ambientais sazonais periódicos, como os fatores físicos já considerados aqui e as variações na concentração de nutrientes e nas atividades de grazing planctônico.

As variáveis mencionadas também são reconhecidas por Trifonova $(1986,1988)$ como os fatores mais importantes para a sucessão sazonal das comunidades fitoplanctônicas. No entanto, o autor faz distinção entre dois tipos de sucessão na ecologia do fitoplâncton de lago. Uma delas, seria a sucessão sazonal, causada por 
periódicas mudanças na dominância de espécies ao longo do ciclo anual, bastante discutida no presente texto; o outro tipo, denominado sucessão geral ou principal, estaria associado à evolução do lago, ou seja, ao processo natural de eutrofização.

Entretanto, muitos autores (Alves, Cavalcanti e Mattos, 1988; Toledo, Freitas e Ferreira, 1988; Diaz, 1990; Ramirez, 1996) consideram que, para sistemas aquáticos de regiões tropicais e subtropicais, as variações diurnas apresentam maior relevância do que as estacionais.

As flutuações diárias de temperatura são capazes de estabelecer padrões de heterogeneidade espacial que interferem nas taxas de sedimentação do fitoplâncton e na distribuição de nutrientes na coluna de água que afetam, ainda, o metabolismo dos organismos planctônicos e suas taxas de crescimento populacional (CALIJURI, 1999).

Segundo Diaz (op cit.), as variações nictemerais são importantes pulsos nos sistemas aquáticos, pois produzem inúmeras alterações em seu funcionamento e influenciam padrões de distribuição vertical dos organismos, modificações nos ciclos biogeoquímicos e na distribuição de biomassa. Em águas continentais, essas variações são produzidas através de interações que ocorrem entre o aquecimento térmico e o efeito da energia ocasionada pelo vento, que geram diferenças de densidade e oscilações verticais no sistema e modificam a estrutura das comunidades planctônicas. 


\section{CARACTERIZAÇÃO DA ÁREA DE ESTUDO}

O sistema de lagoas de estabilização selecionado como universo desta pesquisa, encontra-se localizado no município de Novo Horizonte, na bacia hidrográfica do Tiête/Batalha situada na região centro-oeste do Estado de São Paulo, entre as coordenadas geográficas: $21^{\circ} 28^{\prime} 28^{\prime \prime}$ de latitude e 49¹3’17’’ de longitude.

O município está localizado a 453m de altitude, possui clima quente, inverno seco, com temperatura média anual de $25^{\circ} \mathrm{C}$ e precipitação média de $1.330 \mathrm{~mm}$ por ano; os ventos dominantes são os de sudoeste.

De acordo com o censo demográfico realizado pelo Instituto Brasileiro de Geografia e Estatística (IBGE) em 2000, a população de Novo Horizonte era de 32.432 habitantes; a ETE trata 100\% do esgoto gerado no município. As lagoas de estabilização desse município (Figura 1), construídas e operadas pela SABESP, entraram em funcionamento em fevereiro de 1999. O sistema é do tipo australiano, constituído por três lagoas em série (anaeróbia, facultativa 1 e facultativa 2). O efluente das lagoas é despejado a alguns metros de distância no córrego Três Pontos. As característica das lagoas são apresentadas no quadro 1:

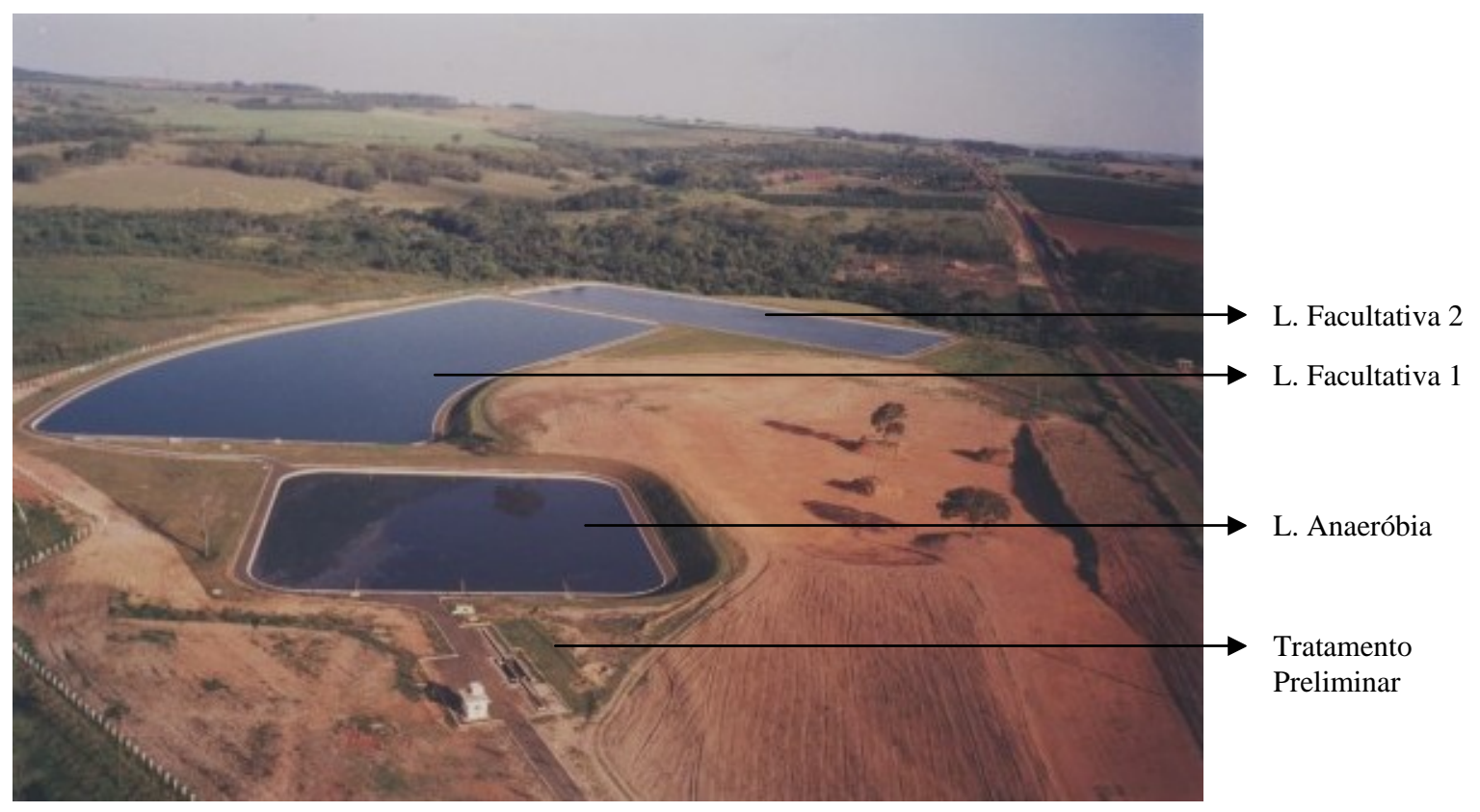

Figura 1: Sistema australiano de lagoas de estabilização de Novo Horizonte, SP (Sabesp, 2002). 
Quadro 1: Características das lagoas de estabilização do sistema australiano de Novo Horizonte, SP, em agosto de 2002.

\begin{tabular}{|c|c|c|c|}
\hline " Variáveis & Lagoa Anaeróbia & $\begin{array}{c}\text { Lagoa Facultativa } \\
1\end{array}$ & $\begin{array}{c}\text { Lagoa Facultativa } \\
2\end{array}$ \\
\hline Área Média (ha) & 0,5700 & 2,2952 & 1,8287 \\
\hline Profundidade (m) & 3,5 & 1,7 & 1,8 \\
\hline Vol. Útil $\left(\mathrm{m}^{3}\right)$ & 19.951 & 39.018 & 32.916 \\
\hline $\begin{array}{l}\text { Vol. Esgoto Médio } \\
\left(\mathrm{m}^{3} / \mathrm{dia}\right)\end{array}$ & 4.015 & 4.015 & 4.015 \\
\hline $\begin{array}{c}\text { Carga Org. Total } \\
\text { (kgDBO/dia) }\end{array}$ & $1.616,000$ & 565,600 & 260,176 \\
\hline DBO afl. (mg/L) & 420 & 147 & 67 \\
\hline DBO efl. (mg/L) & 147 & 67 & 80 \\
\hline $\begin{array}{c}\text { Remoção da DBO } \\
\text { (\%) }\end{array}$ & 65 & 54 & 0 \\
\hline $\begin{array}{c}\text { Tempo de detenção } \\
\text { hidráulico (dias) }\end{array}$ & 5 & 10 & 8 \\
\hline
\end{tabular}

Fonte: SABESP - Novo Horizonte (agosto/2002)

O tempo total de detenção hidráulico do sistema é de 23 dias. 


\section{MATERIAL E MÉTODOS}

\subsection{Metodologia de Amostragem}

As amostras foram coletadas nas lagoas facultativa 1 (E3) e facultativa 2 (E4) e no efluente final (E5) do sistema australiano de lagoas de estabilização do município de Novo Horizonte, SP.

As campanhas foram realizadas em quatro épocas: maio/2002 - outono, agosto/2002 - inverno, novembro/2002 - primavera e fevereiro/2003 - verão, a cada seis horas, durante vinte e quatro horas, no total de cinco amostragens (t0, t1, t2, t3 e t4), com início aproximadamente às 9:30 horas, com exceção do efluente final coletado apenas em t0 e t4.

Com auxílio da garrafa de Van Dorn, as amostras foram coletadas em três profundidades das lagoas: na superfície $(0 \mathrm{~m})$, no meio da coluna de água (aproximadamente 0,7 m) e no fundo (1,5 m); E3S, E3M e E3F, correspondem às três profundidades, respectivamente, na lagoa facultativa 1 e E4S, E4M e E4F na facultativa 2.

Para as análises de DBO e sólidos suspensos, além das lagoas, também foram coletadas amostras no afluente (E1) e no efluente (E2) da lagoa anaeróbia, nos horários t0 e t4.

\subsection{Variável Climatológica}

\subsubsection{Pluviosidade}

Os dados de pluviosidade foram fornecidos pela Cooperativa Coopercitrus, que possui um pluviômetro instalado no município de Novo Horizonte.

\subsection{Variáveis Físicas}

\subsubsection{Temperatura e Condutividade Elétrica}

As medidas de temperatura e condutividade elétrica foram obtidas a partir de perfis da superfície até o fundo, a cada $0.10 \mathrm{~m}$ com a multisonda da marca Yellow Springer, modelo 556 MPS. 


\subsubsection{Transparência da Água, Extensão da Zona Eufótica e Coeficiente de} Atenuação do Contraste Vertical

A transparência da água foi determinada através do disco de Secchi, de $30 \mathrm{~cm}$ de diâmetro, pintado de branco e com cabo graduado de $0.10 \mathrm{~m}$.

A multiplicação dos valores de transparência da água pelo fator 3 resultou na extensão da zona eufótica, de acordo com Cole (1975).

O coeficiente de atenuação do contraste vertical foi calculado de acordo Kirk (1986), segundo a equação:

$$
K=\frac{9}{Z d s}
$$

Onde:

$\mathrm{K}$ = coeficiente de atenuação do contraste vertical

Zds = profundidade em que o disco de Secchi desapareceu (m)

\subsubsection{Material em Suspensão}

O material em suspensão foi determinado pelo método gravimétrico (2.540D e 2.540E) descrito em APHA (1995), em que amostras de volume conhecido foram filtradas em filtros GF/C Sartorius, de fibra de vidro, de 0,45 $\mu \mathrm{m}$ de porosidade e 47 mm de diâmetro, previamente calcinados e pesados $\left(\mathrm{P}_{0}\right)$. A seguir, no Laboratório de Saneamento da Escola de Engenharia de São Carlos, os filtros foram levados à estufa a $130^{\circ} \mathrm{C}$, por 24 horas, para serem então novamente pesados $\left(\mathrm{P}_{1}\right)$ e depois à mufla, a $500^{\circ}$ C, por 15 minutos, tendo sido pesados novamente $\left(\mathrm{P}_{2}\right)$ para a determinação da concentração das frações de sólidos suspensos, através das equações:

$$
\begin{gathered}
\operatorname{SST}(\mathrm{mg} / L)=\frac{\left(P_{1}-P_{0}\right) \times 1000}{V_{a}} \quad \mathrm{SSO}(\mathrm{mg} / \mathrm{L})=\frac{\left(\mathrm{P}_{2}-\mathrm{P}_{0}\right) \times 1000}{\mathrm{~V}_{\mathrm{a}}} \\
\mathrm{SSI}(\mathrm{mg} / \mathrm{L})=\mathrm{SST}-\mathrm{SSO}
\end{gathered}
$$

Onde:

SST = sólidos suspensos totais $(\mathrm{mg} / \mathrm{L})$;

SSO = sólidos suspensos orgânicos (mg/L);

SSI = sólidos suspensos inorgânicos (mg/L);

$\mathrm{V}_{\mathrm{a}}=$ volume da amostra $(\mathrm{mL})$; 
$\mathrm{P}_{\mathrm{o}}=$ peso dos filtros previamente calcinados (g);

$\mathrm{P}_{1}=$ peso dos filtros secos na estufa a $105^{\circ} \mathrm{C}$ por 24 horas, após filtração (g);

$\mathrm{P}_{2}=$ peso dos filtros calcinados na mufla a $500^{\circ} \mathrm{C}$ durante 15 minutos (g).

\subsection{Variáveis Químicas}

\subsubsection{DBO}

Para a determinação dessa variável, utilizou-se o teste de DBO padrão, em que a concentração de oxigênio dissolvido foi determinada no dia da coleta. A seguir, a amostra, mantida em frasco fechado, foi incubada a $20^{\circ} \mathrm{C}$ por cinco dias, quando a concentração de oxigênio dissolvido foi determinada novamente; a diferença entre esta medida e a anterior é o valor da $\mathrm{DBO}_{5}{ }^{20}$ (APHA, 1995).

\subsubsection{Oxigênio Dissolvido e Potencial Hidrogeniônico}

Os perfis de oxigênio dissolvido e pH foram obtidos com a multisonda Yellow Springer - 556 MPS a cada 0,10 m, partindo da superfície até o fundo da lagoa.

\subsubsection{Nutrientes Inorgânicos Dissolvidos}

Os nutrientes inorgânicos analisados foram: nitrogênio amoniacal, nitrito, nitrato e ortofosfato. As amostras de água residual usadas para determinação das concentrações desses nutrientes, com exceção do nitrogênio amoniacal, foram previamente filtradas (filtros de fibra de vidro GF/C Sartorius de 0,45 $\mu \mathrm{m}$ de porosidade e $47 \mathrm{~mm}$ de diâmetro). As análises de nutrientes foram realizadas no Laboratório de Saneamento da Escola de Engenharia de São Carlos.

\subsubsection{Nitrogênio Amoniacal}

O nitrogênio amoniacal foi determinado através do aparelho Büchi 339, em que as amostras passaram por destilação prévia, seguida de titulação colorimétrica (método 4500B), descrito em APHA (1995). 


\subsubsection{Nitrito e Nitrato}

Para as análises das concentrações de nitrito e nitrato, as amostras foram floculadas com hidróxido de alumínio, antes da filtração.

O nitrito foi determinado pelo método colorimétrico (4500B) descrito em APHA (1995), com leitura no comprimento de onda de 543 nm, em espectrofotômetro Shimadzu UV - 160A.

As concentrações do nitrato foram determinadas diretamente após a filtração, pelo método 4500D, descrito em APHA (1995), em espectrofotômetro Shimadzu UV 160A, no comprimento de onda de $220 \mathrm{~nm}$.

\subsubsection{Ortofosfato}

As amostras de ortofosfato foram diluídas, sempre que necessário, segundo a relação DQO: N: P (100: 5: 1) e analisadas pelo método colorimétrico do ácido ascórbico (4500B), descrito em APHA (1995), com leitura a $880 \mathrm{~nm}$, em espectrofotômetro Hach DR/4000 V.

\subsubsection{Nutrientes Totais}

\subsubsection{Nitrogênio Total}

A concentração de nitrogênio foi determinada pelo método macro-Kjedahal, seguido de titulação colorimétrica (método 4500B), descrito em APHA (1995), através do aparelho Büchi 339.

\subsubsection{Fósforo Total}

As amostras de fósforo total foram diluídas com base na relação DQO: N: P, citada anteriormente e analisadas pelo método de digestão com persulfato de potássio (item 5 do método 4500B), seguido pela determinação colorimétrica (método do ácido ascórbico 4500C), segundo APHA (1995), com leitura a $880 \mathrm{~nm}$ em espectrofotômetro Hach DR/4000 V. 


\subsection{Variáveis Biológicas}

\subsubsection{Comunidade Fitoplanctônica}

O fitoplâncton foi coletado nas três profundidades $(0 \mathrm{~m}, 0,7 \mathrm{~m}$ e $1,5 \mathrm{~m})$ das lagoas facultativa 1 e 2 e no efluente final, fixado com solução de formalina 4\% e identificado através do microscópio óptico de epifluorescência Olympus BX 51, com auxílio das seguintes chaves de identificação: Parra, Gonzalez e Dellarossa (1982a, 1982b e 1983); Huber-Pestalozzi (1983); Anagnostidis e Komarek (1988); Menezes (1990); Vyverman (1991); De-Lamonica-Freire, Bicudo e Castro (1992), no Laboratório de Biotoxicologia de Águas Continentais e Efluentes da Escola de Engenharia de São Carlos (BIOTACE).

Os organismos foram quantificados de acordo com o método proposto por Uthermohl (1958), em câmaras de sedimentação de $2 \mathrm{~mL}$, com tempo médio de sedimentação de três horas, em microscópio invertido Olympus CK 2.

Foram considerados como um indivíduo: organismos unicelulares, filamentos (de cianobactérias, clorofíceas e diatomáceas) e colônias (de cianofíceas e diatomáceas).

Para as amostras coletadas no período de maio de 2002, foram estabelecidos cem campos de contagem ou cem indivíduos da espécie mais freqüente. Na maioria das contagens, os cem indivíduos predominantes eram obtidos antes do qüinquagésimo campo.

A maioria das amostras dos períodos seguintes (agosto/2002, novembro/2002 e fevereiro/2003) precisaram de diluições (1:1 e 1:3) para serem contadas em câmaras de $2 \mathrm{~mL}$, devido à grande quantidade de pequenas células de Chlorella. Alguns testes de contagem foram feitos com essas amostras, utilizando-se a curva de estabilização e foi observado que todas as espécies presentes na câmara apareciam logo nos primeiros campos, não surgindo mais espécies diferentes depois do sexto campo. Além disso, os cem indivíduos mais freqüentes de uma mesma espécie eram contados por volta do terceiro campo. Portanto, ficou estabelecida a contagem de 10 a 15 campos de cada amostra, distribuídos pela câmara, como mostra a Figura 2 (tomando o devido cuidado para não contar campos próximos à borda): 


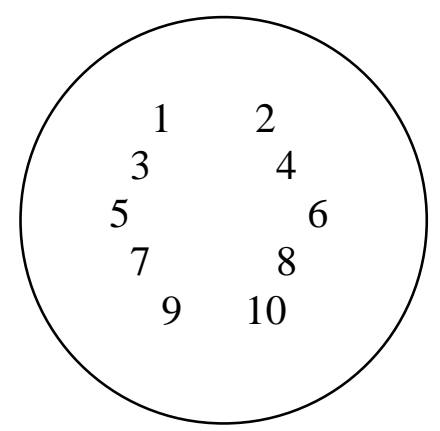

Figura 2: Representação do campo do microscópio invertido mostrando como as lâminas foram contadas, a partir da terceira coleta.

Nas amostras de fitoplâncton foram estimadas a densidade, a diversidade, a dominância, a eqüidade e a riqueza de espécies, além da porcentagem de contribuição das classes e o biovolume.

\subsubsection{Riqueza}

A riqueza foi avaliada segundo o número de espécies encontradas nos quatro períodos de estudo.

\subsubsection{Densidade Específica}

A densidade dos organismos fitoplanctônicos foi calculada segundo critérios descritos em APHA (1995):

$$
\mathrm{D}(\mathrm{org} / \mathrm{mL})=\frac{C \cdot A t}{A f \cdot F \cdot V}
$$

Onde:

$\mathrm{D}=$ densidade (organismos $/ \mathrm{mL}$ )

$\mathrm{C}=$ número de organismos contados

$\operatorname{At}\left(\mathrm{mm}^{2}\right)=$ área total do fundo da câmara de sedimentação

$\operatorname{Af}\left(\mathrm{mm}^{3}\right)=$ área do campo de contagem

$\mathrm{F}=$ número de campos contados

$\mathrm{V}(\mathrm{mL})=$ volume da amostra sedimentada

\subsubsection{Porcentagem de Contribuição das Classes}

A porcentagem de contribuição das classes (PCC) foi calculada em relação à densidade total encontrada em cada amostra, pela equação: 


$$
P C C=\left(D_{c} / D_{t}\right) \times 100
$$

Onde:

PCC $=$ porcentagem de contribuição das classes;

$\mathrm{D}_{\mathrm{c}}=$ densidade de cada classe;

$\mathrm{D}_{\mathrm{t}}=$ densidade total.

\subsubsection{Abundância Relativa}

A abundância relativa foi estimada a partir do número de indivíduos de cada espécie em relação ao número total de indivíduos de cada amostra. As espécies foram classificadas, de acordo com McCllough e Jackson (1985) em: dominantes, para os que obtiveram de 50 a 100\% de abundância relativa; abundantes, para os que apresentaram de 30 a 49\%; comuns, para os que tiveram de 10 a 29\%; ocasionais, para aquelas com 1 a $9 \%$; e raros, para os que apresentaram menos de $1 \%$.

\subsubsection{5 Índices de Diversidade de Espécies, Dominância, Equidade e Riqueza}

Para cálculo da diversidade de espécies foi usado o índice de Shannon-Weaver (SHANNON e WEAVER, 1963):

$$
\mathrm{H}^{\prime}=-\sum p i \cdot \log p i
$$

Onde:

H’= índice de Shannon-Weaver

$\mathrm{pi}=\mathrm{ni} / \mathrm{N}$

ni = número de indivíduos da espécie i

$\mathrm{N}$ = número total de indivíduos

O índice de equidade foi baseado nos valores de H'de Shannon:

$$
\mathrm{E}=\frac{H^{\prime}}{\log S}
$$

Onde:

$\mathrm{E}=$ equidade

H'= índice de Shannon-Weaver 
S = número total de espécies

Os índices de dominância e riqueza foram calculados de acordo com Simpson (1949):

$$
c=\sum\left(\frac{n i}{N}\right)^{2} \quad d=\frac{S-1}{\log _{2} N}
$$

Onde:

c = índice de dominância

$\mathrm{d}$ = índice de riqueza

ni = número de importância de cada espécie

$\mathrm{N}$ = número total de indivíduos

$\mathrm{S}=$ número de espécies encontradas na amostra

\subsubsection{Biovolume}

Os cálculos de biovolume foram realizados para os táxons dominantes, abundantes e comuns presentes nas amostras.

De cada táxon, foram mensurados, em média, cerca de trinta organismos de cada espécie distribuídos aleatoriamente entre todas amostras analisadas, para obtenção do volume celular médio. Esse volume foi calculado a partir da semelhança da célula algal às formas geométricas, como sugerido por Wetzel e Likens (1991):

$$
\text { VCmédio }=\sum V i \cdot n
$$

Onde:

$\mathrm{VC}=$ volume celular médio $\left(\mu \mathrm{m}^{3}\right)$

$\mathrm{Vi}=$ volume celular individual $\left(\mu \mathrm{m}^{3}\right)$

$\mathrm{n}$ = número de indivíduos medidos

Biovolume $\left(\mu \mathrm{m}^{3}\right)=$ VC médio. $\mathrm{n}^{0}$ médio de organismos encontrados

\subsubsection{Estrutura de Tamanho dos Organismos Pertencentes à Comunidade}

Os organismos foram agrupados por tamanho, de acordo com suas dimensões axiais máximas (GALD), segundo Garcia de Emiliani (1993). Essas dimensões referem- 
se à média obtida com a mensuração de alguns organismos distribuídos aleatoriamente entre todas as amostras, como realizado para o biovolume. Foram considerados três grupos de tamanho: picoplâncton $(0,2-2,0 \mu \mathrm{m})$, nanoplâncton $(2,0-20,0 \mu \mathrm{m})$ e microplâncton $(20,0-200,0 \mu \mathrm{m})$.

\subsubsection{Clorofila a e feofitina}

Para a determinação da concentração de clorofila a, volumes conhecidos de amostra foram filtrados (filtros de fibra de vidro GF/C Sartorius de 0,45 $\mu$ m de porosidade e $47 \mathrm{~mm}$ de diâmetro). Posteriormente, estes filtros foram macerados com acetona $90 \%$ a frio e centrifugados em centrífuga Eppendorf a $4.000 \mathrm{rpm}$, por duas vezes; na primeira delas por 10 minutos e na segunda, por 15 minutos para então ser feita a leitura em espectrofotômetro Hach DR/4000 V; a seguir as amostras foram acidificadas com ácido clorídrico $0,1 \mathrm{~N}$ realizando-se nova leitura para determinação da concentração de feofitina. As metodologias utilizadas estão descritas em APHA (1995).

As equações de Lorenzen (1967) foram utilizadas para cálculo da concentração de clorofila a e feofitina:

$$
\text { [Clorofila a (ug/L)] = 26,7 } \cdot\left(\text { Abs.664 } b-A b s .665_{a}\right)
$$

Onde:

26,7 = fator de correção para acetona.

Abs.b = absorbância no comprimento de onda de $664 \mathrm{~nm}$.

Abs.a $_{\mathrm{a}}=$ absorbância no comprimento de onda de $665 \mathrm{~nm}$.

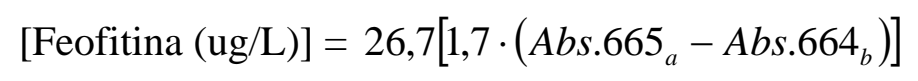

Onde:

26,7 = fator de correção para acetona.

1,7 = fator de correção para o ácido clorídrico 0,1 N.

Abs.b = absorbância no comprimento de onda de $664 \mathrm{~nm}$.

Abs.a $_{\text {a }}$ absorbância no comprimento de onda de 665 nm. 


\section{RESULTADOS}

\subsection{Variável Climatológica}

\subsubsection{Pluviosidade}

Nos meses que antecederam a primeira coleta, em 2002 (outono), a precipitação foi muito baixa, esteve ausente no mês de abril e atingiu $60 \mathrm{~mm}^{3}$ em maio (mês em que ocorreu a coleta). Os meses seguintes também apresentaram baixos valores de pluviosidade: zero em junho, $17 \mathrm{~mm}^{3}$ em julho e $35 \mathrm{~mm}^{3}$ em agosto (novamente mês de coleta), valores característicos desse período considerado seco. A precipitação voltou a aumentar em outubro e novembro (124 $\mathrm{mm}^{3}$ para ambos) e no mês de janeiro de 2003, foi registrada a maior precipitação $\left(534 \mathrm{~mm}^{3}\right)$. Em fevereiro, mês de coleta, a pluviosidade acumulada foi de 220,5 $\mathrm{mm}^{3}$ (Figura 3).

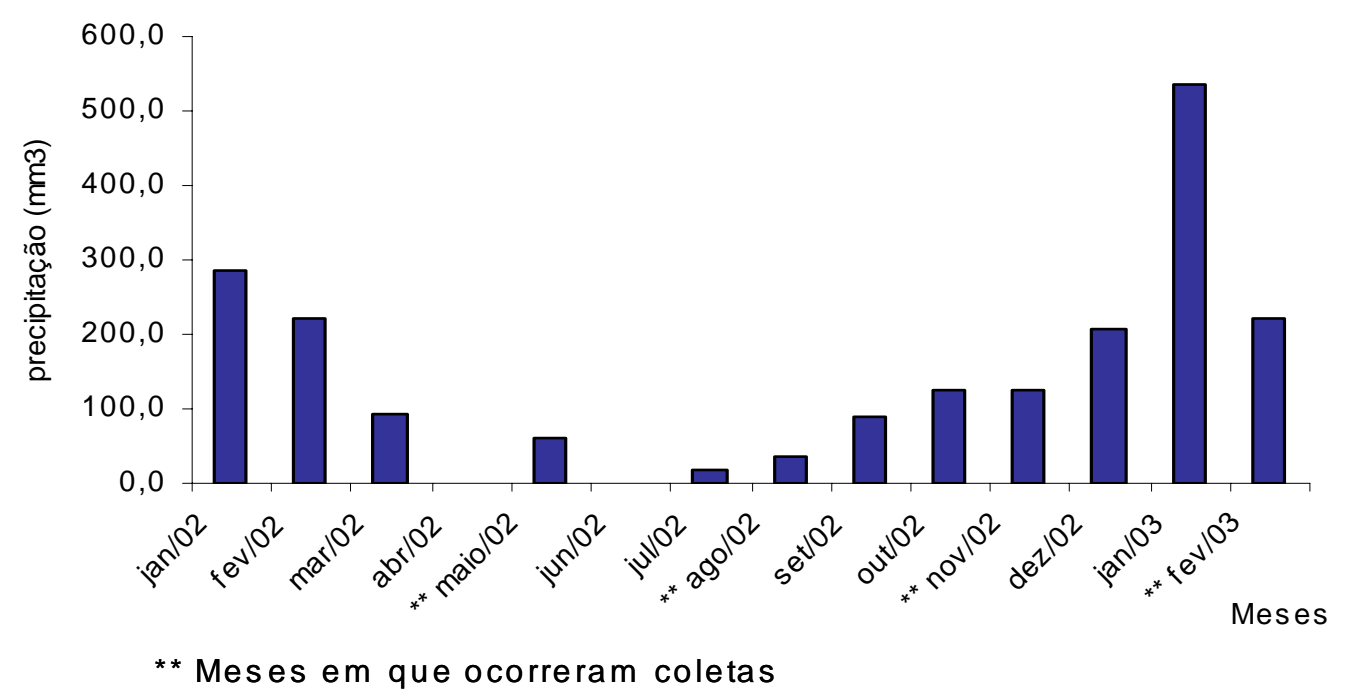

Figura 3: Precipitação mensal $\left(\mathrm{mm}^{3}\right)$ registrada no município de Novo Horizonte, SP, entre janeiro de 2002 e fevereiro de 2003.

\subsection{Variáveis Físicas da Água}

\subsubsection{Temperatura}

Os perfis de temperatura obtidos não apresentaram variação significativa entre horários, profundidades e períodos de estudo e foram semelhantes em ambas as lagoas. As oscilações não foram significativas nem mesmo entre inverno e verão. Os coeficientes de variação são apresentados no Apêndice A.

No outono, a variável foi constante em torno de $25^{\circ} \mathrm{C}$ a $25,5^{\circ} \mathrm{C}$, em toda a 
coluna de água, nos horários da manhã (t0 e t4) e da madrugada (t3). Os maiores valores foram registrados à tarde $(\mathrm{t} 1), 28,9^{\circ} \mathrm{C}$ em $\mathrm{E} 3$ e $31,1^{\circ} \mathrm{C}$ em $\mathrm{E} 4$; em t2 a temperatura da superfície também esteve alta, $27^{\circ} \mathrm{C}$ nas duas lagoas. No entanto, o fundo de ambas lagoas, tanto em t1 quanto em t2, permaneceu em torno de $25^{\circ} \mathrm{C}$ (Figuras 4 e 5 ).

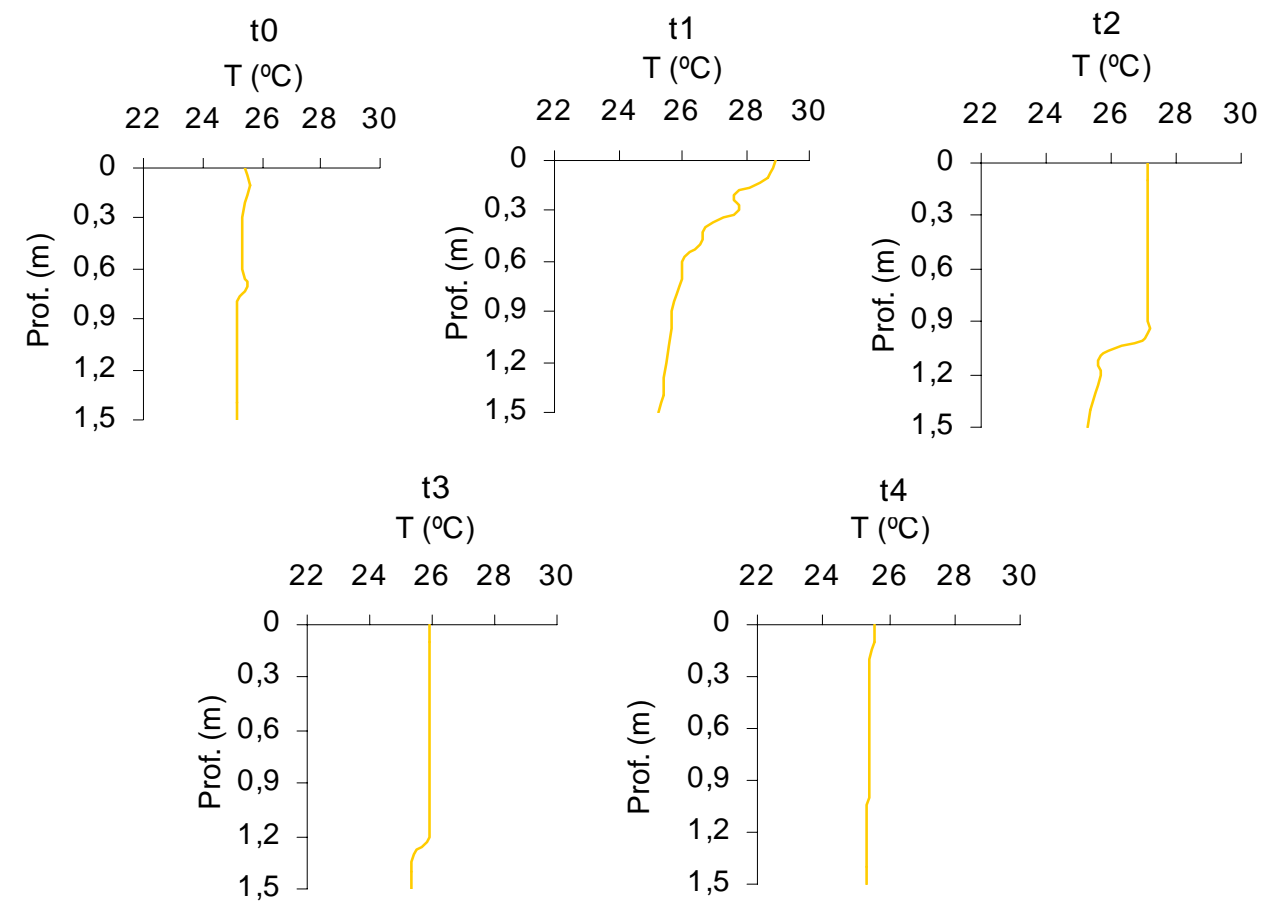

Figura 4: Perfis de temperatura $\left({ }^{\circ} \mathrm{C}\right)$ obtidos na lagoa facultativa 1, da ETE de Novo Horizonte, SP, no outono (maio/2002).

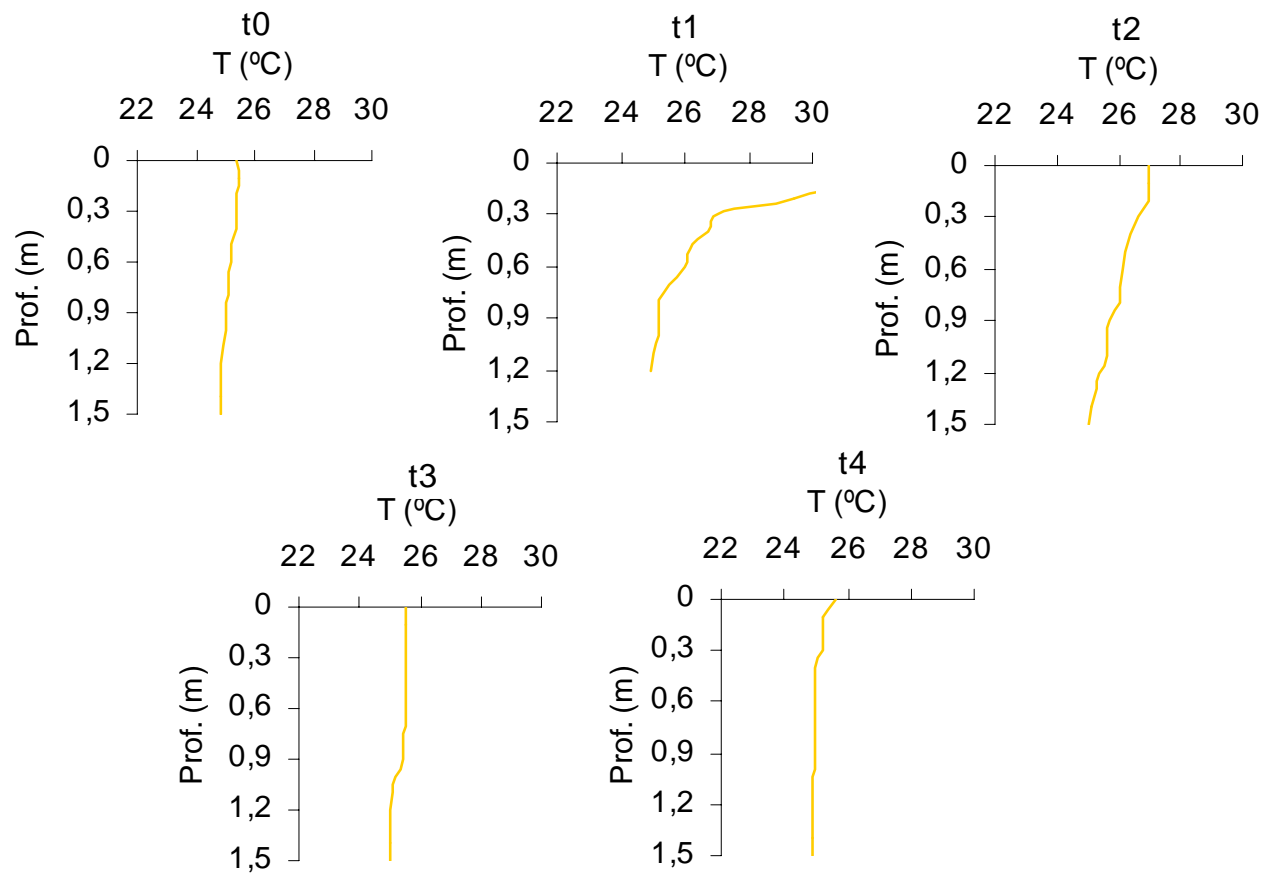

Figura 5: Perfis de temperatura $\left({ }^{\circ} \mathrm{C}\right)$ obtidos na lagoa facultativa 2, da ETE de Novo Horizonte, SP, no outono (maio/2002). 
No inverno, a variação de temperatura foi menor que no outono. Em t0, t3 e t4, a variável apresentou-se constante $\left(23^{\circ} \mathrm{C}\right)$ em toda a coluna de água. Em t1 e t2, em toda a massa de água, as temperaturas estiveram um pouco mais altas na superfície, por volta de $25,4^{\circ} \mathrm{C}$ e $24^{\circ} \mathrm{C}$, respectivamente (Figuras 6 e 7 ).

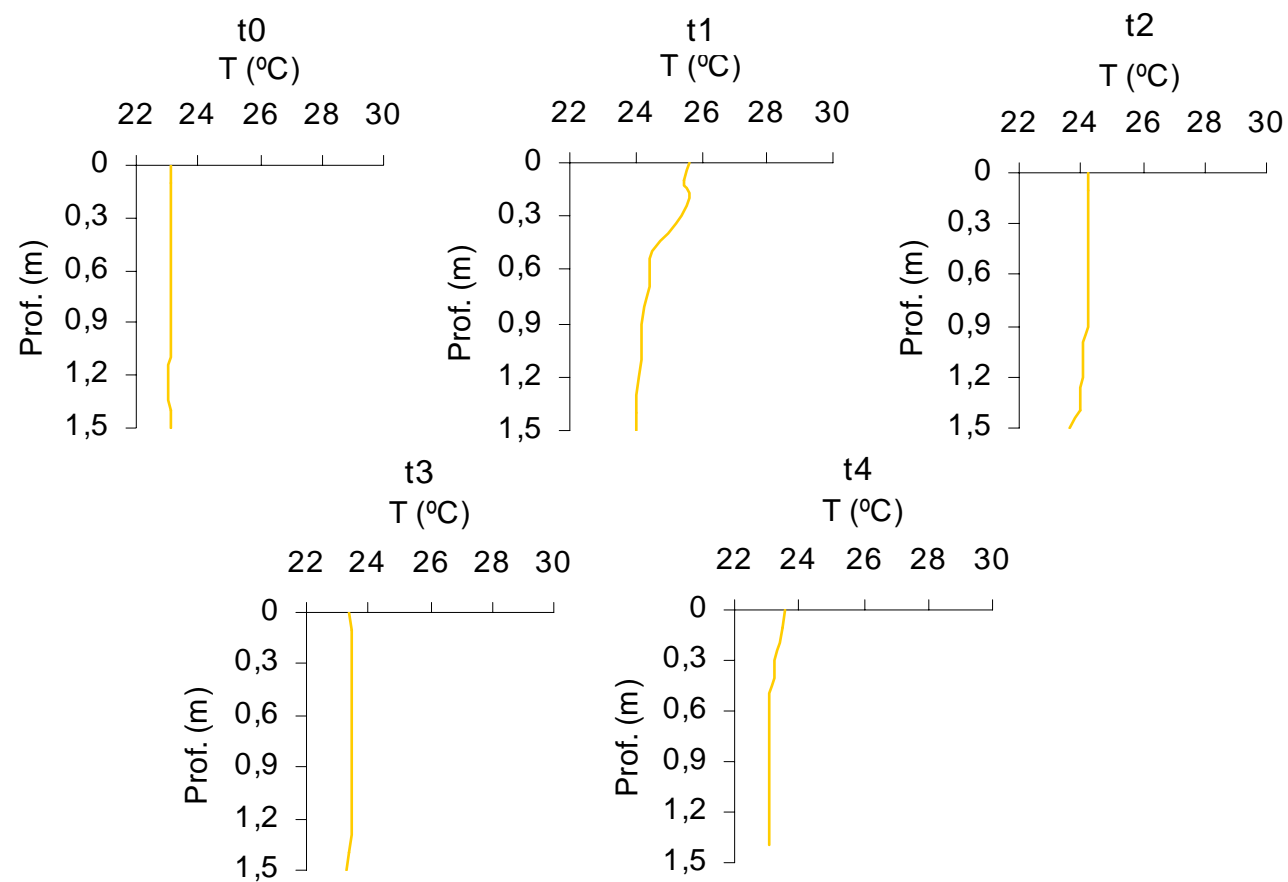

Figura 6: Perfis de temperatura $\left({ }^{\circ} \mathrm{C}\right)$ obtidos na lagoa facultativa 1, da ETE de Novo Horizonte, SP, no inverno (agosto/2002).

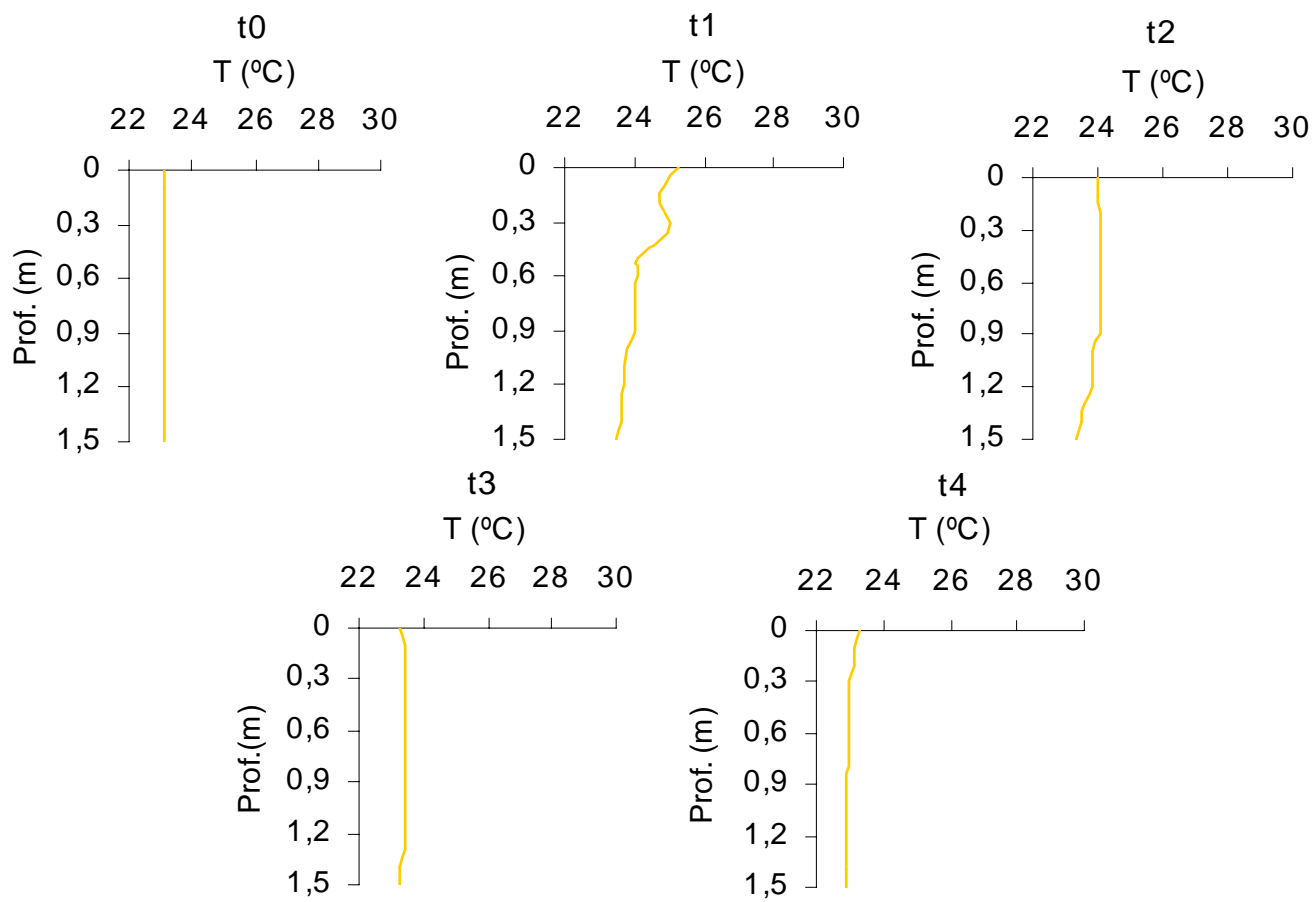

Figura 7: Perfis de temperatura $\left({ }^{\circ} \mathrm{C}\right)$ obtidos na lagoa facultativa 2, da ETE de Novo Horizonte, SP, no inverno (agosto/2002). 
Na primavera, a temperatura mostrou-se constante na coluna de água em todos os horários; em t0, t2 e t3, registrou-se valores em torno de $25^{\circ} \mathrm{C}$; em t1, obteve-se o maior valor do período, na faixa dos $26^{\circ} \mathrm{C}$; e em t4, por volta de $24^{\circ} \mathrm{C}$ (Figuras 8 e 9).

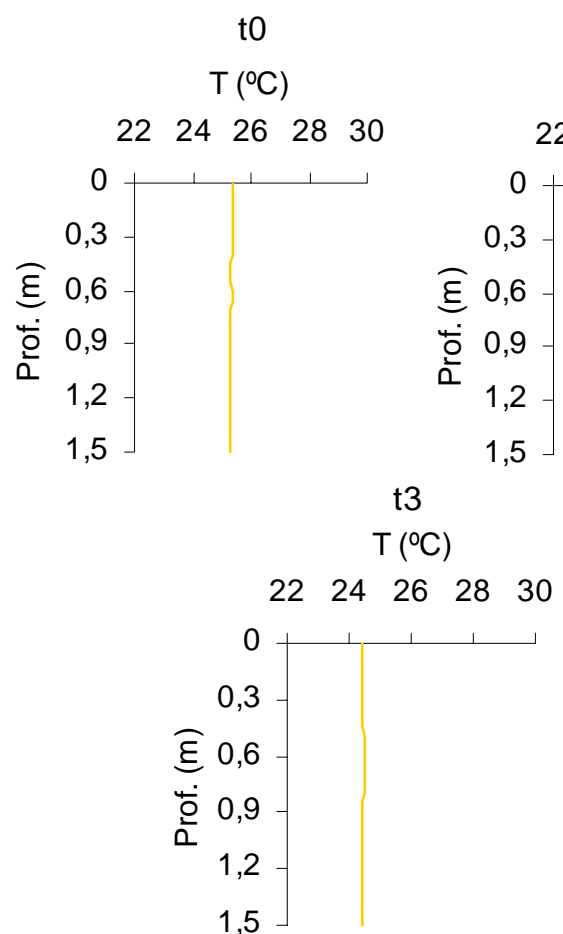

$\mathrm{t1}$

$\mathrm{T}\left({ }^{\circ} \mathrm{C}\right)$

$\begin{array}{lllll}22 & 24 & 26 & 28 & 30\end{array}$

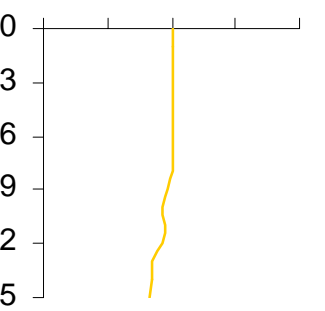

t2

$\mathrm{T}\left({ }^{\circ} \mathrm{C}\right)$

$\begin{array}{lllll}22 & 24 & 26 & 28 & 30\end{array}$

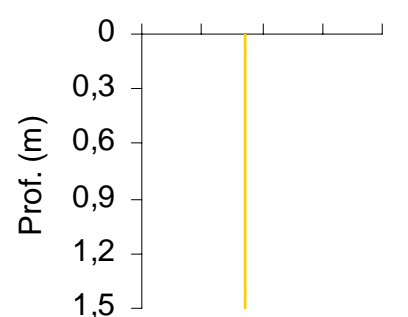

t4

$\mathrm{T}\left({ }^{\circ} \mathrm{C}\right)$

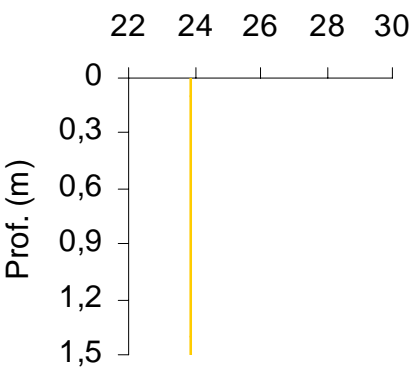

Figura 8: Perfis de temperatura $\left({ }^{\circ} \mathrm{C}\right)$ obtidos na lagoa facultativa 1, da ETE de Novo Horizonte, na primavera (novembro/2002).

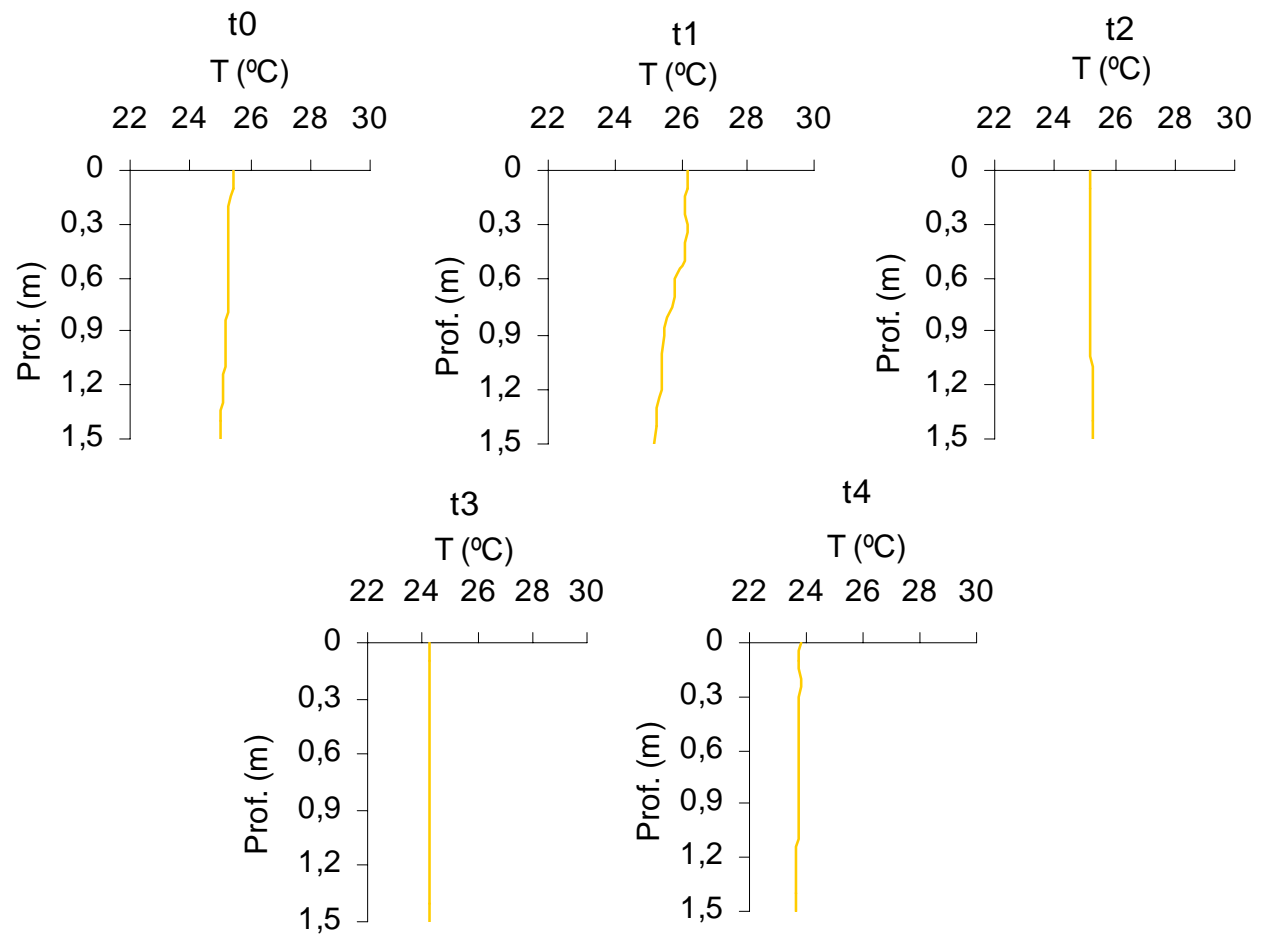

Figura 9: Perfis de temperatura $\left({ }^{\circ} \mathrm{C}\right)$ obtidos na lagoa facultativa 2, da ETE de Novo Horizonte, SP, na primavera (novembro/2002). 
No verão, as oscilações foram mais pronunciadas, com diferenças de 7 e $8^{\circ} \mathrm{C}$, entre a superfície e o fundo, como aconteceu em $\mathrm{t} 1$ nas lagoas facultativa 1 e facultativa 2, respectivamente. Neste horário foram registradas as mais altas temperaturas: $36,2^{\circ} \mathrm{C}$ na primeira lagoa facultativa e $38,8^{\circ} \mathrm{C}$ na outra. Em t0, t3 e t4 essa variável mostrou-se constante por toda a coluna de água, em torno de $30^{\circ} \mathrm{C}$. A temperatura do fundo permaneceu por volta de $29^{\circ} \mathrm{C}$ em todos os horários (Figuras 10 e 11).

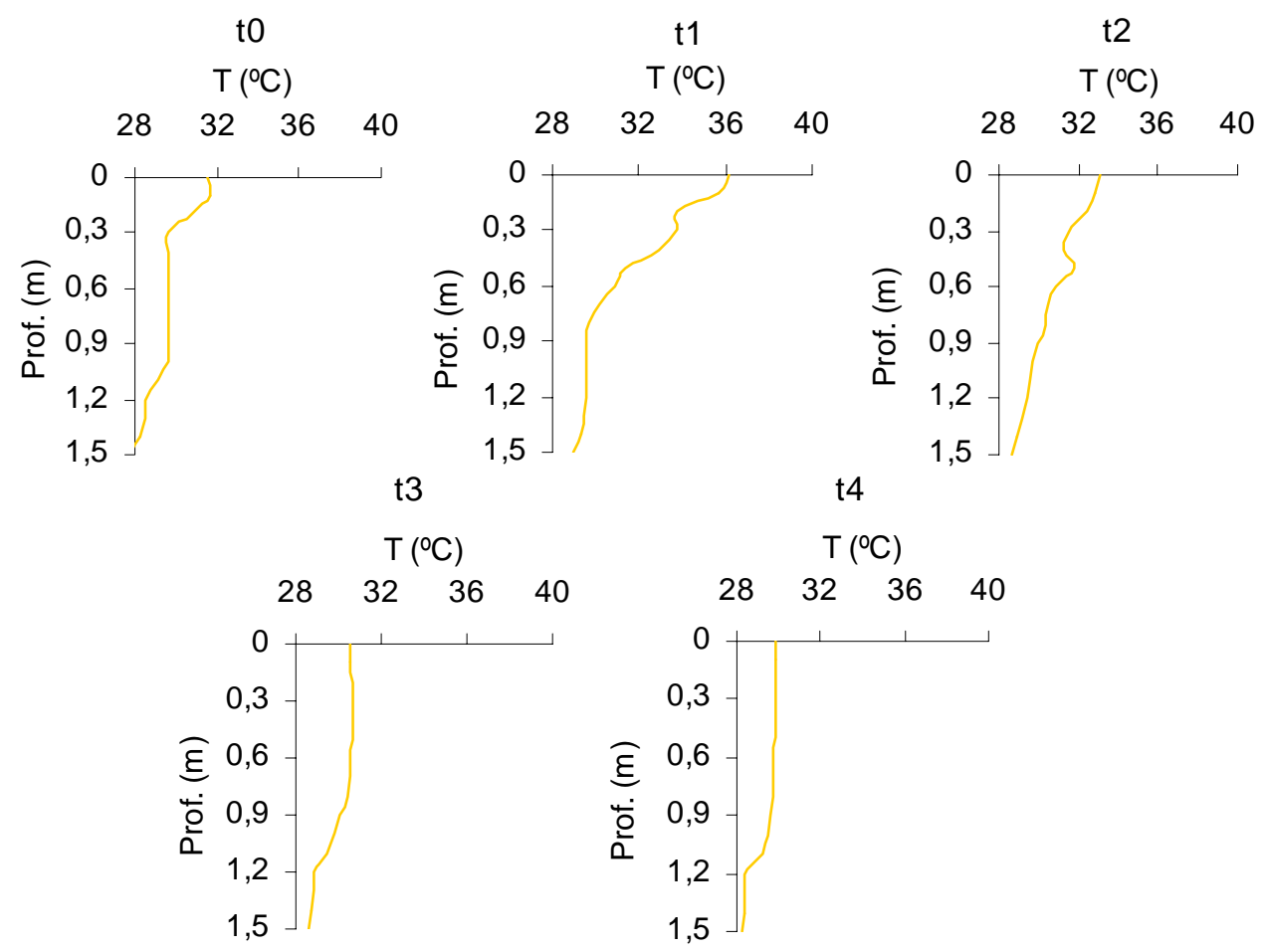

Figura 10: Perfis de temperatura $\left({ }^{\circ} \mathrm{C}\right)$ obtidos na lagoa facultativa 1 da ETE de Novo Horizonte, SP, no verão (fevereiro/2003). 


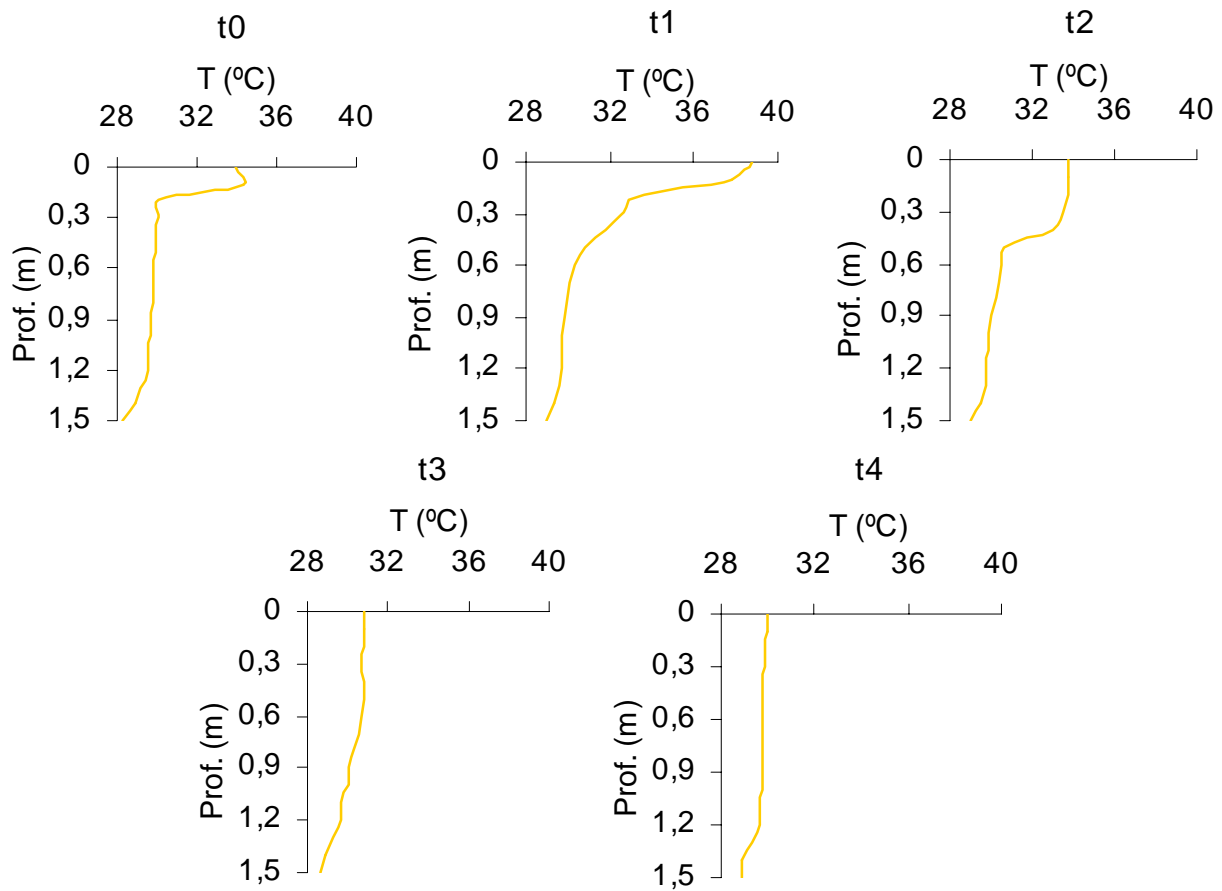

Figura 11: Perfis de temperatura $\left({ }^{\circ} \mathrm{C}\right)$ obtidos na lagoa facultativa 2, da ETE de Novo Horizonte, SP, no verão (fevereiro/2003).

No efluente final, as temperaturas foram idênticas em t0 e t4, no inverno e no verão, $23^{\circ} \mathrm{C}$ e $30^{\circ} \mathrm{C}$, respectivamente. No outono, $26,3^{\circ} \mathrm{C}$ em t0 e $25,5^{\circ} \mathrm{C}$ em t4; e na primavera, $25,6^{\circ} \mathrm{C}$ e $24,2^{\circ} \mathrm{C}$, para os mesmos horários, respectivamente (Figura 12).

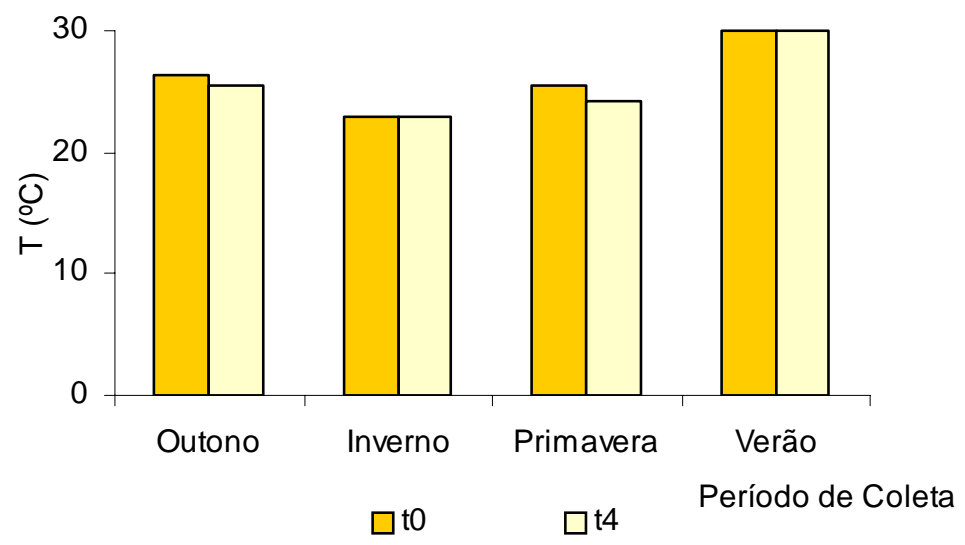

Figura 32: Temperatura $\left({ }^{\circ} \mathrm{C}\right)$ obtida no efluente final da ETE de Novo Horizonte, SP, nos períodos estudados.

\subsubsection{Condutividade Elétrica}

A condutividade elétrica da água, assim como ocorreu com a temperatura, apresentou poucas oscilações entre os períodos de estudo. 
No outono, as variações entre os horários, as profundidades e as lagoas foi pequena, entre $0,82 \mathrm{mS} / \mathrm{cm}$ e $0,83 \mathrm{mS} / \mathrm{cm}$, com exceção de $\mathrm{t} 1$, em que foram registrados os maiores valores da estação, 0,87 mS/cm, nas duas lagoas (Figuras 13 e 14).

t0

Cond. $(\mathrm{mS} / \mathrm{cm})$

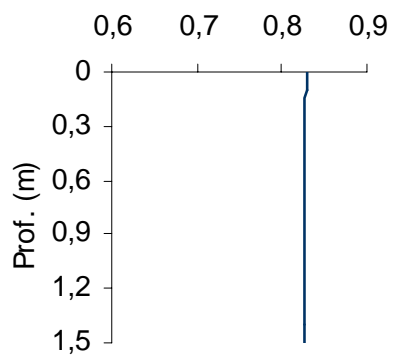

t1

Cond. $(\mathrm{mS} / \mathrm{cm})$ $\mathrm{t} 2$

Cond. $(\mathrm{mS} / \mathrm{cm})$
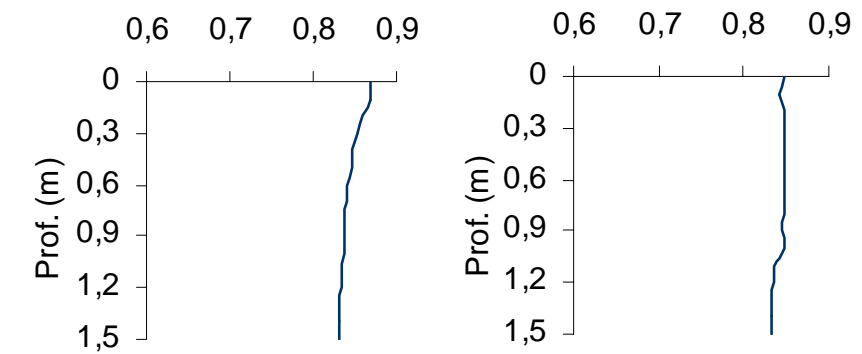

t3

Cond. (mS/cm)

t4

Cond. $(\mathrm{mS} / \mathrm{cm})$
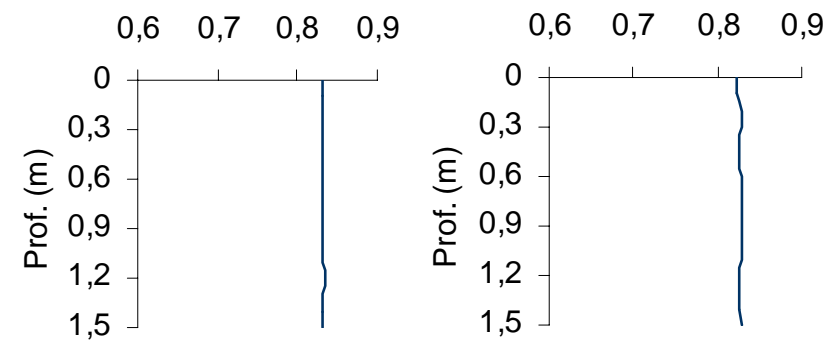

Figura 13: Perfis de condutividade elétrica da água $(\mathrm{mS} / \mathrm{cm})$ obtidos na lagoa facultativa 1, da ETE de Novo Horizonte, SP, no outono (maio/2002).

t0

Cond. $(\mathrm{mS} / \mathrm{cm})$ t1

Cond. $(\mathrm{mS} / \mathrm{cm})$ t2

Cond. $(\mathrm{mS} / \mathrm{cm})$
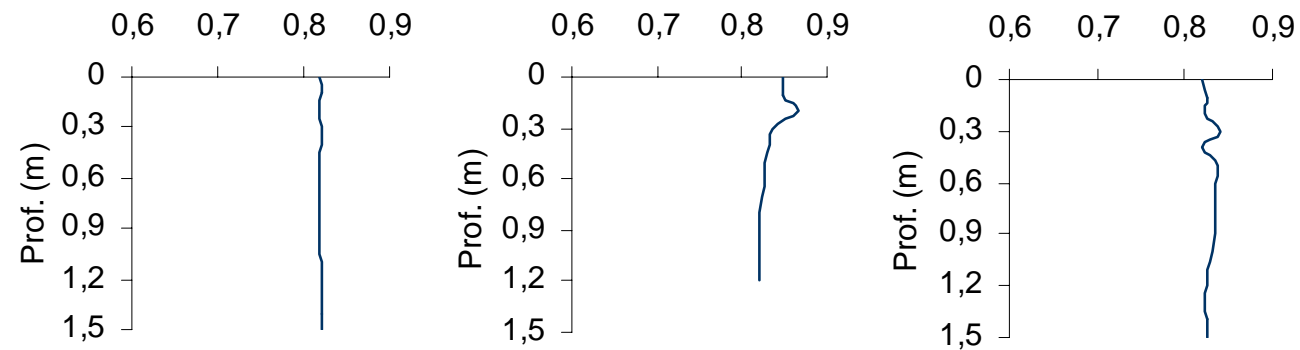

t3

Cond. $(\mathrm{mS} / \mathrm{cm})$

t4

Cond. $(\mathrm{mS} / \mathrm{cm})$
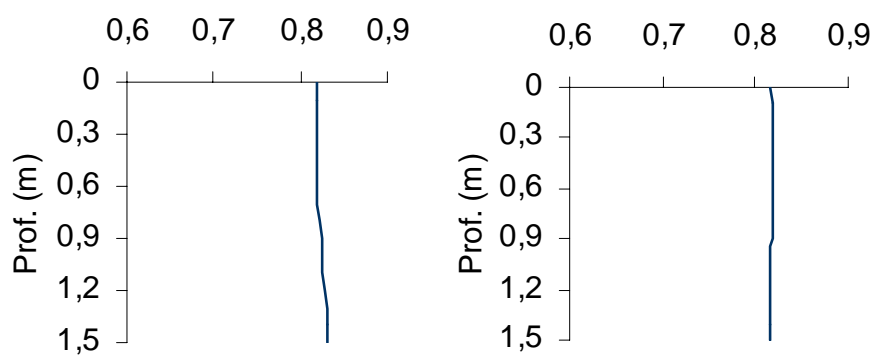

Figura 14: Perfis de condutividade elétrica da água $(\mathrm{mS} / \mathrm{cm})$ obtidos na lagoa facultativa 2, da ETE de novo Horizonte, SP, no outono (maio/2002). 
No inverno, em t1, t2 e t3 na lagoa facultativa 1 e em t3 na facultativa 2, a condutividade elétrica foi constante por toda a coluna de água, em torno de $0,74 \mathrm{mS} / \mathrm{cm}$. Nos horários da manhã (t0 e t4), ficou na faixa de $0,73 \mathrm{mS} / \mathrm{cm}$, nas duas lagoas (Figuras 15 e 16).

t0

Cond. $(\mathrm{mS} / \mathrm{cm})$

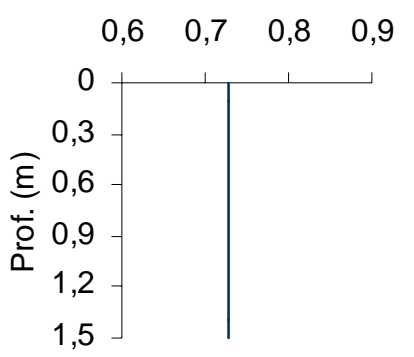

t1

Cond. $(\mathrm{mS} / \mathrm{cm})$ t2

Cond. $(\mathrm{mS} / \mathrm{cm})$

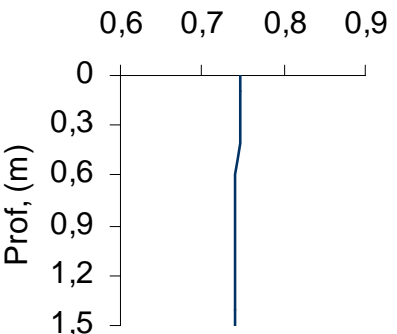

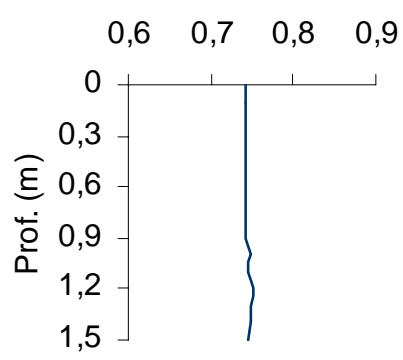

t4

Cond. $(\mathrm{mS} / \mathrm{cm})$

Cond. $(\mathrm{mS} / \mathrm{cm})$
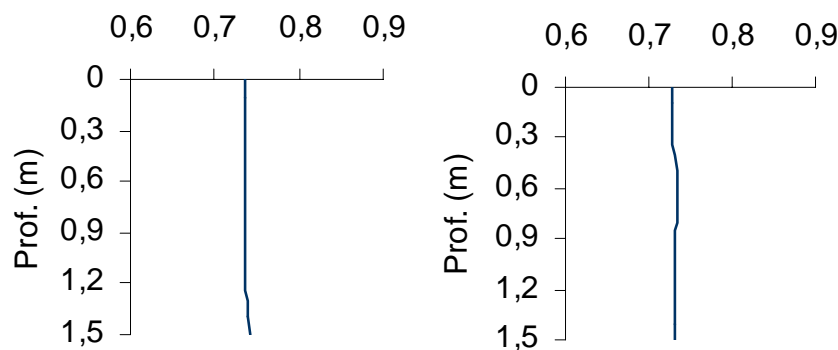

Figura 15: Perfis de condutividade elétrica da água $(\mathrm{mS} / \mathrm{cm})$ obtidos na lagoa facultativa 1 , da ETE de Novo Horizonte, SP, no inverno (agosto/2002).

to

Cond. $(\mathrm{mS} / \mathrm{cm})$

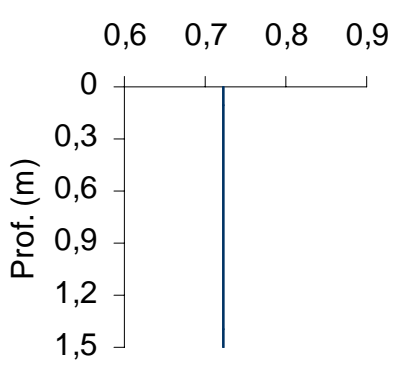

$\mathrm{t} 1$

Cond. $(\mathrm{mS} / \mathrm{cm})$ t2

Cond. $(\mathrm{mS} / \mathrm{cm})$
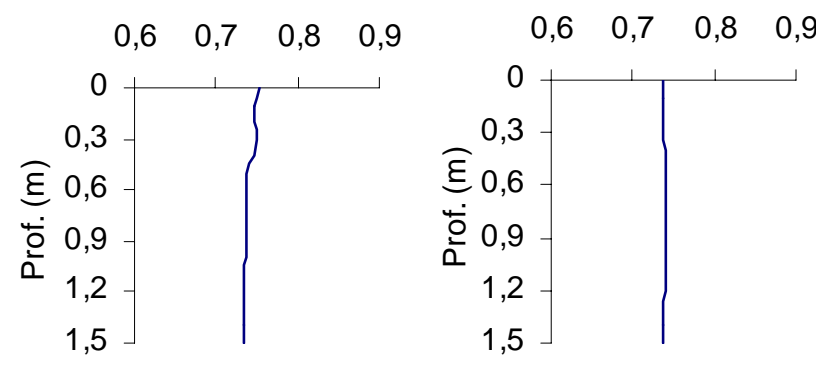

t4

Cond. $(\mathrm{mS} / \mathrm{cm})$

Cond. $(\mathrm{mS} / \mathrm{cm})$
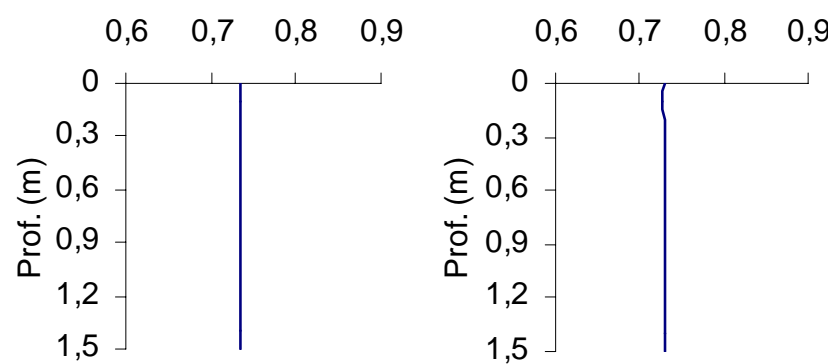

Figura 16: Perfis de condutividade elétrica da água $(\mathrm{mS} / \mathrm{cm})$ obtidos na lagoa facultativa 2, da ETE de Novo Horizonte, SP, no inverno (agosto/2002). 
Em novembro (primavera), além de pequena variação, a condutividade mostrouse constante ao longo das profundidades e semelhantes entre as lagoas. Em t0 e t2, o valor foi de $0,82 \mathrm{mS} / \mathrm{cm}$; em $\mathrm{t} 1$, foram observados os maiores valores, em torno de 0,83 $\mathrm{mS} / \mathrm{cm}$; e em t3 e t4, os menores, $0,81 \mathrm{mS} / \mathrm{cm}$ e 0,80 mS/cm, para E3 e E4, respectivamente. (Figuras 17 e 18).

t0

Cond. $(\mathrm{mS} / \mathrm{cm})$

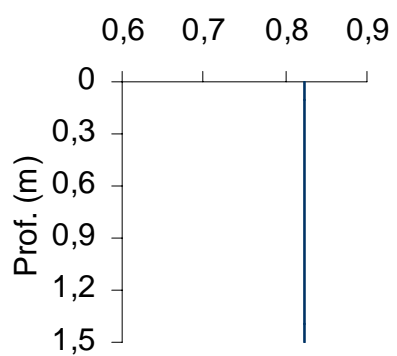

t1

Cond. $(\mathrm{mS} / \mathrm{cm})$ $\mathrm{t} 2$

Cond. $(\mathrm{mS} / \mathrm{cm})$

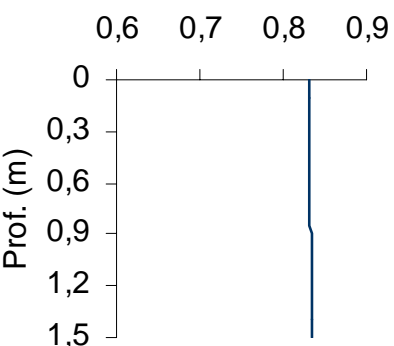

t3

Cond. $(\mathrm{mS} / \mathrm{cm})$

t4

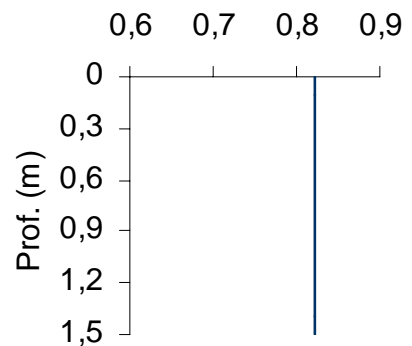

4

Cond. $(\mathrm{mS} / \mathrm{cm})$
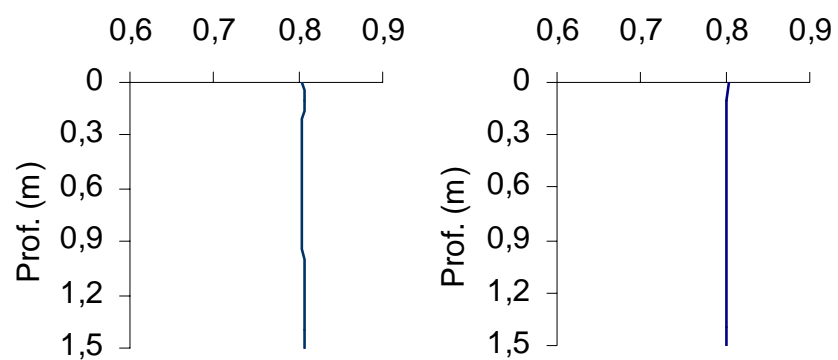

Figura 17: Perfis de condutividade elétrica da água $(\mathrm{mS} / \mathrm{cm})$ obtidos na lagoa facultativa 1 , da ETE de Novo Horizonte, SP, na primavera (novembro/2002). 
t0

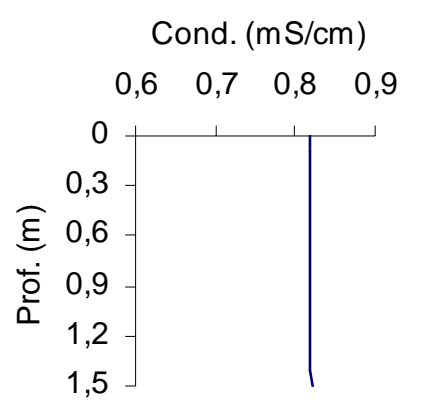

$\mathrm{t} 1$

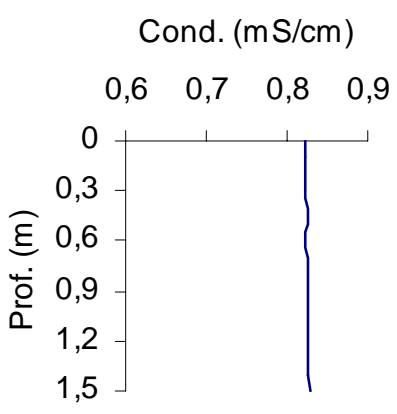

t2

Cond. (mS/cm)

t3
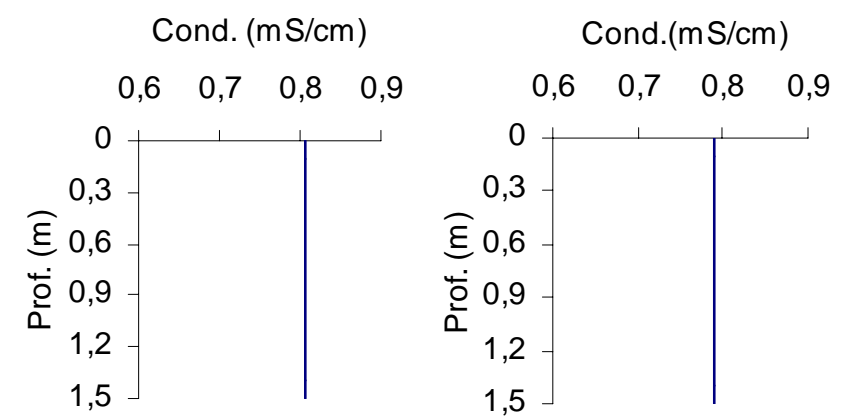

Figura 18: Perfis de condutividade elétrica da água $(\mathrm{mS} / \mathrm{cm})$ obtidos na lagoa facultativa 2, da ETE de Novo Horizonte, SP, na primavera (novembro/2002).

No período quente ocorreram as maiores flutuações dessa variável. O valor mais alto, $1,03 \mathrm{mS} / \mathrm{cm}$, registrado na superfície, assim como as maiores variações (fundo com $0,94 \mathrm{mS} / \mathrm{cm}$ ), aconteceram em t1, na primeira lagoa facultativa; em t4, na mesma lagoa e em t1, na facultativa 2, foram registrados valores constantes na coluna de água (0,95 $\mathrm{mS} / \mathrm{cm}$ e 0,93 mS/cm, respectivamente). O primeiro horário de coleta nas duas lagoas e t3 e t4 na última lagoa, mostraram condutividades crescentes da superfície $(0,9 \mathrm{mS} / \mathrm{cm})$ até o fundo (0,97 mS/cm) (Figuras 19 e 20). 
t0

Cond. $(\mathrm{mS} / \mathrm{cm})$

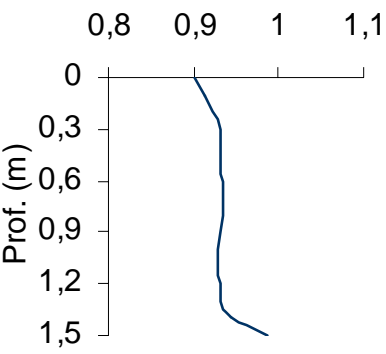

t1

Cond. $(\mathrm{mS} / \mathrm{cm})$ t2

Cond. (m $/ \mathrm{cm}$ )

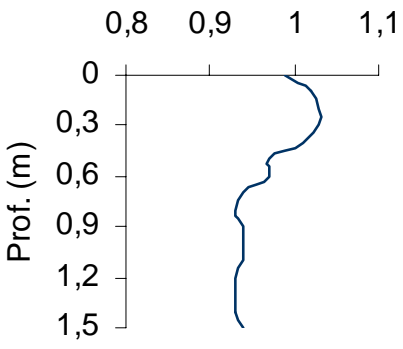

t3

Cond. $(\mathrm{mS} / \mathrm{cm})$

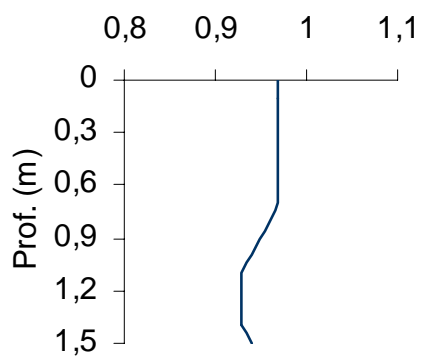

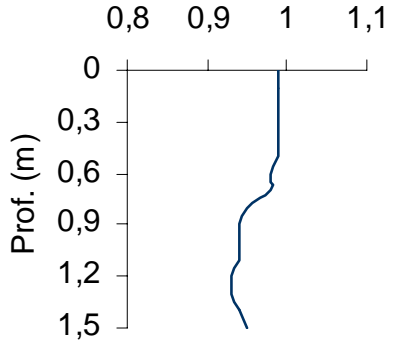

$\mathrm{t} 4$

Cond. (mS/cm)

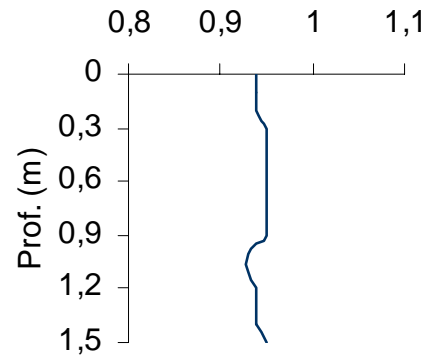

Figura 19: Perfis de condutividade elétrica da água $(\mathrm{mS} / \mathrm{cm})$ obtidos na lagoa facultativa 1 , da ETE de Novo Horizonte, SP, no verão (fevereiro/2003).

to

Cond. $(\mathrm{mS} / \mathrm{cm})$

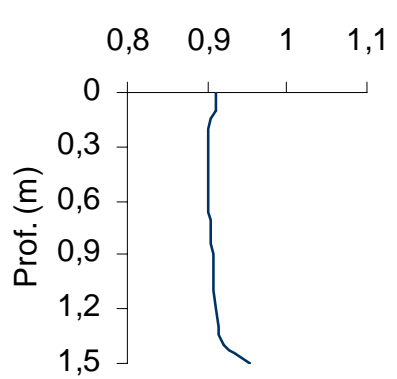

t1

Cona. $(\mathrm{mS} / \mathrm{cm})$ t2

Cond. $(\mathrm{m} \mathrm{S} / \mathrm{cm})$
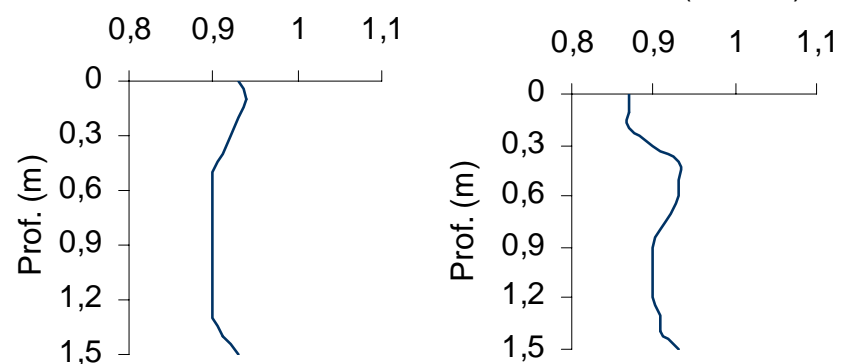

t4

t3

Cond. $(\mathrm{mS} / \mathrm{cm})$

Cond. $(\mathrm{mS} / \mathrm{cm})$
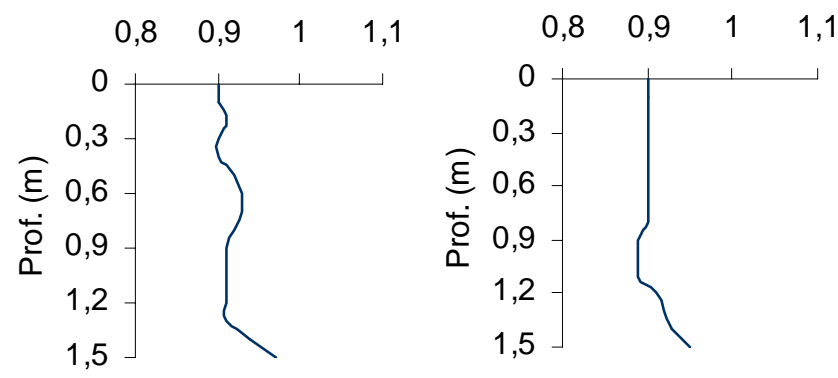

Figura 20: Perfis de condutividade elétrica da água $(\mathrm{mS} / \mathrm{cm})$ obtidos na lagoa facultativa 2, da ETE de Novo Horizonte, no verão (fevereiro/2003).

O efluente final apresentou os seguintes valores, em t0 e t4, para essa variável: no outono, $0,83 \mathrm{mS} / \mathrm{cm}$ e $0,82 \mathrm{mS} / \mathrm{cm}$, respectivamente; e na primavera $0,82 \mathrm{mS} / \mathrm{cm}$ e $0,79 \mathrm{mS} / \mathrm{cm}$, respectivamente; no inverno, $0,72 \mathrm{mS} / \mathrm{cm}$ e no verão, $0,90 \mathrm{mS} / \mathrm{cm}$, para ambos horários (Figura 21). 


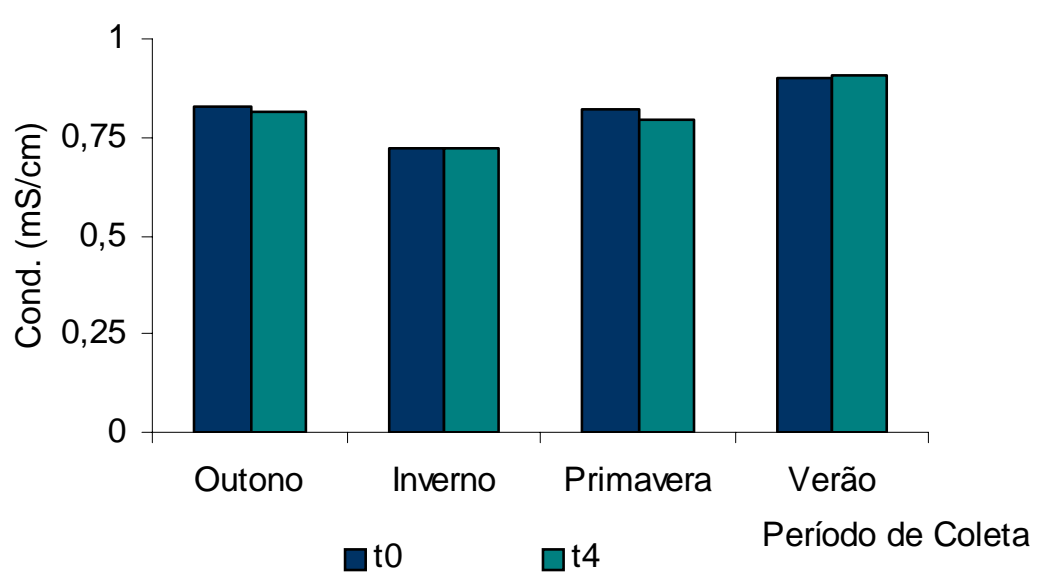

Figura 21: Condutividade elétrica $(\mathrm{mS} / \mathrm{cm})$ obtida no efluente final da ETE de Novo Horizonte, nos períodos estudados.

\subsubsection{Transparência da Água, Extensão da Zona Eufótica e Coeficiente de Atenuação do Contraste Vertical}

As maiores profundidades de desaparecimento do disco de Secchi foram registradas na lagoa facultativa 2, no verão: $0,27 \mathrm{~m}$ e $0,20 \mathrm{~m}$ em t1 e t4, respectivamente. Em todos os outros horários e períodos de coleta, a profundidade de Secchi não ultrapassou $0,11 \mathrm{~m}$, com extensão máxima da zona eufótica de 0,33 $\mathrm{m}$. Os menores valores foram registrados no inverno, o menor deles, de 0,04 m, foi encontrado na lagoa facultativa 1 em t4; conseqüentemente, neste período, foram obtidos os maiores valores de coeficiente de atenuação do contraste vertical (225) (Tabela 1).

Tabela 1: Profundidades (m) de desaparecimento do disco de Secchi (Zds) e da zona eufótica (Zeu) e coeficiente de atenuação do contraste vertical (K), nos períodos e estações amostrados, na ETE de Novo Horizonte, SP.

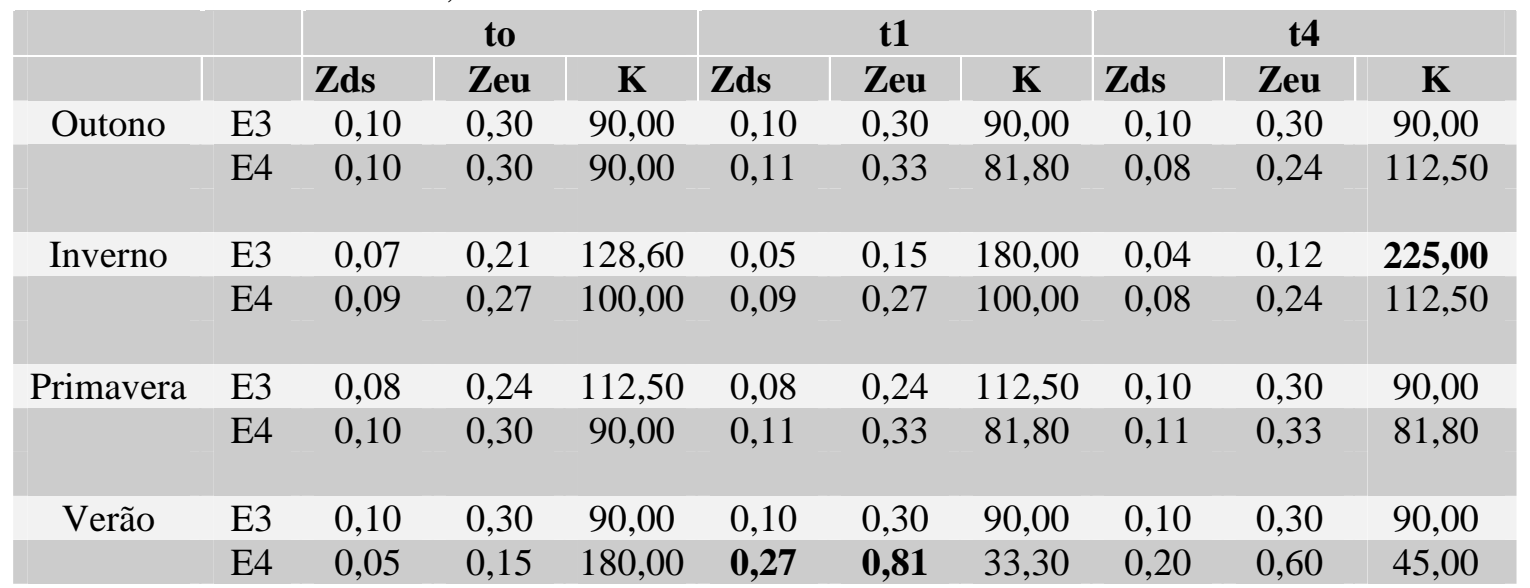




\subsubsection{Material em Suspensão}

Comparando-se os resultados encontrados para a concentração de sólidos suspensos totais entre os horários e os períodos de coleta, observou-se que o maior valor, em E1, ocorreu em t4, no inverno (406 mg/L); conseqüentemente, nas outras estações os valores também foram altos; no entanto, a superfície da primeira lagoa facultativa, em t0, apresentou valor muito superior que o da entrada (E1), $632 \mathrm{mg} / \mathrm{L}$; Em t4 também foram encontradas elevadas concentrações no outono (394 mg/L), na primavera (360 mg/L) e no verão (318 mg/L) para as entradas (E1). Os resultados para cada profundidade e horário são apresentados nas Tabelas 2 e 3.

As concentrações de sólidos suspensos orgânicos foram maiores que as de inorgânicos e representaram mais de $80 \%$ dos sólidos totais em todas as estações, horários e períodos de coleta, o que também pode ser observado nas tabelas a seguir. 
Tabela 2: Concentrações (mg/L) de sólidos suspensos, totais (SST), inorgânicos (SSI) e orgânicos (SSO), nas estações de coleta da ETE de Novo Horizonte, no outono (maio/2002) e no inverno (agosto/2002).

\begin{tabular}{|c|c|c|c|c|c|c|c|}
\hline \multirow[b]{2}{*}{$\begin{array}{c}\text { Horário } \\
\text { De Coleta }\end{array}$} & \multirow[b]{2}{*}{ Estação } & \multicolumn{3}{|c|}{ Outono } & \multicolumn{3}{|c|}{ Inverno } \\
\hline & & SST & SSI & SSO & SST & SSI & SSO \\
\hline \multirow[t]{9}{*}{ T0 } & E1 & 141 & 24 & 117 & 324 & 54 & 270 \\
\hline & E2 & 46 & 4 & 42 & 43 & 3 & 40 \\
\hline & E3S & 108 & 25 & 83 & 632 & 216 & 416 \\
\hline & E3M & 119 & 23 & 96 & 280 & 20 & 260 \\
\hline & E3F & 115 & 17 & 98 & 404 & 72 & 332 \\
\hline & E4S & 97 & 20 & 77 & 268 & 24 & 244 \\
\hline & E4M & 117 & 19 & 98 & 520 & 200 & 320 \\
\hline & $\mathrm{E} 4 \mathrm{~F}$ & 100 & 20 & 80 & 404 & 44 & 360 \\
\hline & E5 & 58 & 6 & 52 & 53 & 4 & 49 \\
\hline \multirow[t]{6}{*}{ T1 } & E3S & 104 & 16 & 88 & 314 & 16 & 298 \\
\hline & E3M & 98 & 12 & 86 & 310 & 30 & 280 \\
\hline & E3F & 95 & 20 & 75 & 262 & 26 & 236 \\
\hline & E4S & 119 & 21 & 98 & 180 & 22 & 158 \\
\hline & E4M & 116 & 22 & 94 & 186 & 34 & 152 \\
\hline & $\mathrm{E} 4 \mathrm{~F}$ & 105 & 12 & 93 & 184 & 32 & 152 \\
\hline \multirow[t]{6}{*}{$\mathrm{T} 2$} & E3S & 87 & 20 & 67 & 200 & 20 & 180 \\
\hline & E3M & 102 & 20 & 82 & 216 & 24 & 192 \\
\hline & E3F & 97 & 14 & 83 & 170 & 16 & 154 \\
\hline & E4S & 82 & 14 & 68 & 202 & 30 & 172 \\
\hline & E4M & 88 & 18 & 70 & 196 & 30 & 166 \\
\hline & $\mathrm{E} 4 \mathrm{~F}$ & 98 & 12 & 86 & 178 & 26 & 152 \\
\hline \multirow[t]{6}{*}{ T3 } & E3S & 81 & 5 & 76 & 192 & 24 & 168 \\
\hline & E3M & 83 & 8 & 75 & 186 & 22 & 164 \\
\hline & E3F & 84 & 10 & 74 & 194 & 20 & 174 \\
\hline & E4S & 89 & 4 & 85 & 180 & 10 & 170 \\
\hline & E4M & 71 & 19 & 52 & 178 & 34 & 144 \\
\hline & $\mathrm{E} 4 \mathrm{~F}$ & 91 & 21 & 70 & 166 & 22 & 144 \\
\hline \multirow[t]{9}{*}{$\mathrm{t} 4$} & E1 & 394 & 70 & 324 & 406 & 50 & 356 \\
\hline & E2 & 47 & 4 & 43 & 56 & 8 & 48 \\
\hline & E3S & 106 & 21 & 85 & 328 & 32 & 296 \\
\hline & E3M & 93 & 8 & 85 & 262 & 38 & 224 \\
\hline & E3F & 98 & 18 & 80 & 214 & 28 & 186 \\
\hline & E4S & 91 & 19 & 72 & 220 & 34 & 186 \\
\hline & E4M & 97 & 20 & 77 & 188 & 26 & 162 \\
\hline & $\mathrm{E} 4 \mathrm{~F}$ & 94 & 13 & 81 & 192 & 34 & 158 \\
\hline & E5 & 107 & 19 & 88 & 210 & 32 & 178 \\
\hline
\end{tabular}


Tabela 3: Concentrações (mg/L) de sólidos suspensos, totais (SST), inorgânicos (SSI) e orgânicos (SSO), nas estações de coleta da ETE de Novo Horizonte, na primavera (novembro/2002) e no verão (fevereiro/2003).

\begin{tabular}{|c|c|c|c|c|c|c|c|}
\hline \multirow[b]{2}{*}{$\begin{array}{l}\text { Horário } \\
\text { De Coleta }\end{array}$} & \multirow[b]{2}{*}{ Estação } & \multicolumn{3}{|c|}{ Primavera } & \multicolumn{3}{|c|}{ Verão } \\
\hline & & SST & SSI & SSO & SST & SSI & SSO \\
\hline \multirow[t]{9}{*}{ T0 } & E1 & 292 & 16 & 276 & 262 & 28 & 234 \\
\hline & E2 & 61 & 14 & 47 & 41 & 5 & 36 \\
\hline & E3S & 147 & 32 & 115 & 116 & 12 & 104 \\
\hline & E3M & 143 & 31 & 112 & 93 & 7 & 86 \\
\hline & E3F & 140 & 26 & 114 & 89 & 5 & 84 \\
\hline & E4S & 124 & 33 & 91 & 45 & 1 & 44 \\
\hline & E4M & 89 & 8 & 81 & 26 & 2 & 24 \\
\hline & E4F & 116 & 35,1 & 80,9 & 69 & 7 & 62 \\
\hline & E5 & 122 & 23 & 99 & 42 & 8 & 34 \\
\hline \multirow[t]{6}{*}{$\mathrm{t} 1$} & E3S & 118 & 25 & 93 & 151 & 10 & 141 \\
\hline & E3M & 133 & 20 & 113 & 102 & 3 & 99 \\
\hline & E3F & 98 & 14 & 84 & 103 & 8 & 95 \\
\hline & E4S & 114 & 23 & 91 & 105 & 7 & 98 \\
\hline & E4M & 105 & 20 & 85 & 37 & 2 & 35 \\
\hline & E4F & 103 & 20 & 83 & 40 & -7 & 47 \\
\hline \multirow[t]{6}{*}{ t2 } & E3S & 117 & 21 & 96 & 123 & 3 & 120 \\
\hline & E3M & 118 & 16 & 102 & 113 & 3 & 110 \\
\hline & E3F & 120 & 15 & 105 & 87 & 3 & 84 \\
\hline & E4S & 105 & 24 & 81 & 41 & -11 & 52 \\
\hline & E4M & 106 & 24 & 82 & 38 & 3 & 35 \\
\hline & E4F & 99 & 16 & 83 & 56 & 7 & 49 \\
\hline \multirow[t]{6}{*}{ t3 } & E3S & 113 & 113 & 0 & 138 & 11 & 127 \\
\hline & E3M & 115 & 15 & 100 & 234 & 21 & 213 \\
\hline & E3F & 119 & 11 & 108 & 76 & -3 & 79 \\
\hline & E4S & 93 & 14 & 79 & 92 & 8 & 84 \\
\hline & E4M & 98 & 19 & 79 & 44 & 10 & 34 \\
\hline & $\mathrm{E} 4 \mathrm{~F}$ & 87 & 11 & 76 & 51 & 7 & 44 \\
\hline \multirow[t]{9}{*}{ t4 } & E1 & 360 & 56 & 304 & 318 & 50 & 268 \\
\hline & E2 & 42 & 2 & 40 & 43 & 7 & 36 \\
\hline & E3S & 124 & 17 & 107 & 156 & 12 & 144 \\
\hline & E3M & 110 & 12 & 98 & 99 & 6 & 93 \\
\hline & E3F & 125 & 17 & 108 & 89 & -2 & 91 \\
\hline & E4S & 107 & 20 & 87 & 50 & 3 & 47 \\
\hline & E4M & 112 & 20 & 92 & 41 & 3 & 38 \\
\hline & E4F & 110 & 22 & 88 & 48 & 5 & 43 \\
\hline & E5 & 103 & 20 & 83 & 52 & 6 & 46 \\
\hline
\end{tabular}

A eficiência deste sistema de lagoas de estabilização na remoção de sólidos suspensos pode ser observada na Figura 22. Em todos os períodos houve diminuição significativa (como pode ser observado nos coeficientes de variação no Apêndice A) nas concentrações de sólidos de E1 para E5: de $141 \mathrm{mg} / \mathrm{L}$ para $58 \mathrm{mg} / \mathrm{L}$ em t0 e de 394 mg/L para 107 mg/L em t4, no outono; de 324 mg/L para 53 mg/L em t0 e de 406 mg/L 
para 210 mg/L em t4, no inverno; de 292 mg/L para 122 mg/L em t0 e de 360 para 103 mg/L, na primavera; e de $262 \mathrm{mg} / \mathrm{L}$ para $42 \mathrm{mg} / \mathrm{L}$ em t0 e de $318 \mathrm{mg} / \mathrm{L}$ para $52 \mathrm{mg} / \mathrm{L}$, no verão. As concentrações mais altas foram encontradas no inverno; além disso, em t0, as lagoas apresentaram maiores concentrações de sólidos suspensos do que o afluente (E1), $632 \mathrm{mg} / \mathrm{L}$ na superfície e $404 \mathrm{mg} / \mathrm{L}$ no fundo e $520 \mathrm{mg} / \mathrm{L}$ no meio da lagoa de maturação.
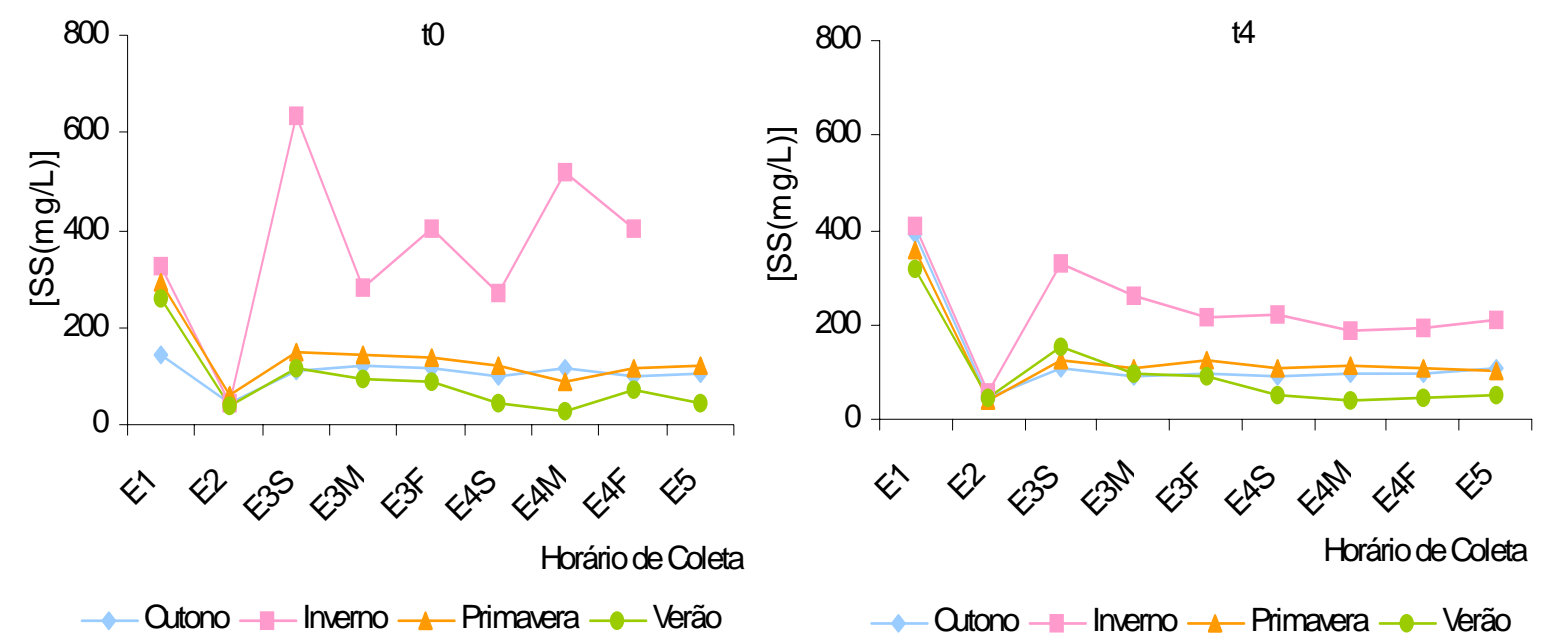

Figura 42: Remoção de sólidos suspensos totais ao longo do tratamento na ETE de Novo Horizonte, SP, nos períodos de estudo, em t0 e 4 .

\subsection{Variáveis Químicas da Água}

\subsubsection{DBO}

As maiores concentrações de DBO foram obtidas no outono $(726 \mathrm{mg} / \mathrm{L}$ em t0 e $1273 \mathrm{mg} / \mathrm{L}$ em t4), ambas no afluente. Em todos os períodos foram observadas diminuições significativas do afluente para o efluente (Apêndice A); a maior delas ocorreu no verão, com remoção de $85 \%$ da DBO no efluente final do sistema. No outono e no inverno a remoção esteve em torno de 70\%; e na primavera foi verificada a menor entre todos os períodos, somente $47 \%$ de remoção. As concentrações de DBO ao longo do sistema são apresentadas na figura 23. 

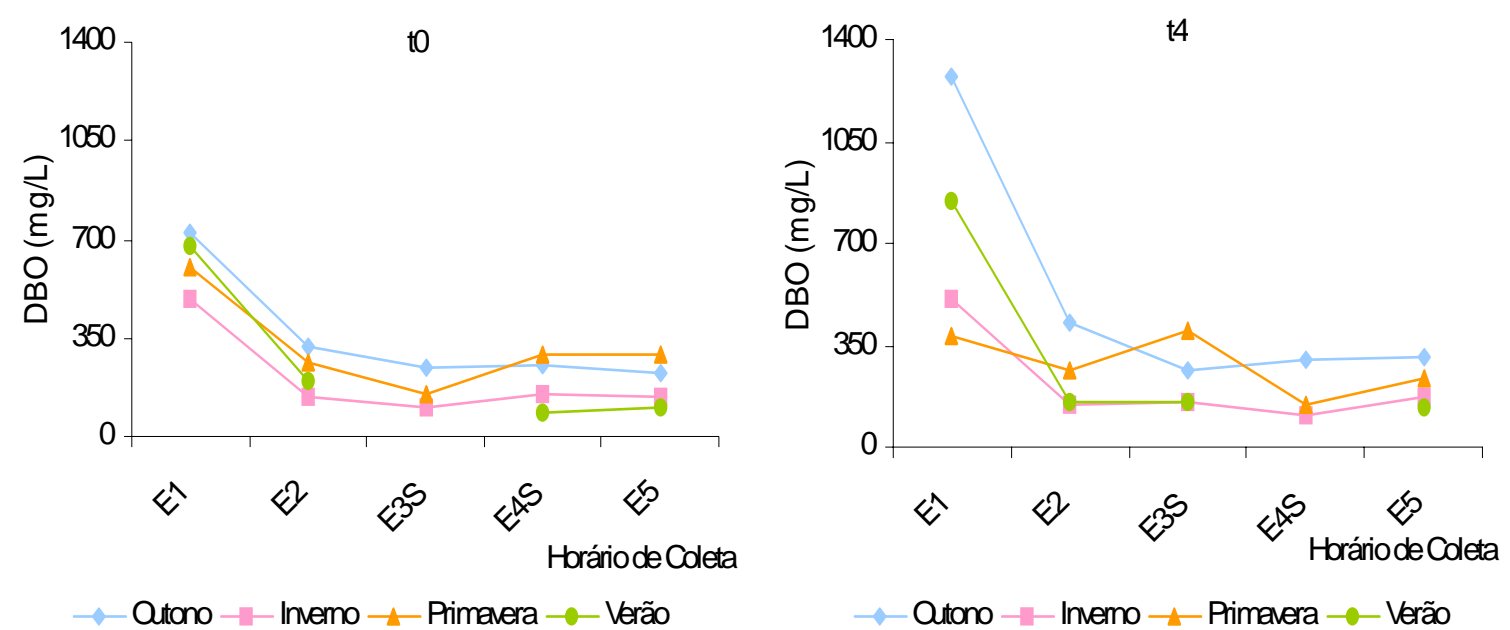

Figura 23: Concentrações de DBO (mg/L) ao longo do tratamento na ETE de Novo Horizonte, SP, nas épocas de estudo, em t0 e t4.

\subsubsection{Oxigênio Dissolvido}

Em geral, as maiores concentrações de oxigênio dissolvido foram encontradas na superfície das lagoas, nos horários da tarde (t1), em todos os períodos de estudo, exceto na primavera, quando os valores se mostraram bem diferentes dos demais; estes valores são citados a seguir, na ordem das lagoas, ou seja, primeiro a facultativa 1 depois a facultativa 2: no outono, as concentrações foram 3,1 mg/L e 19,2 mg/L, sendo este último valor o maior registrado entre todos os períodos; no inverno, foram encontradas concentrações de 10,8 mg/L e 5,5 mg/L; e no verão, de 9 mg/L e 13,3 mg/L.

No outono, na superfície da lagoa facultativa 1 , concentrações de $0,3 \mathrm{mg} / \mathrm{L}$ foram encontradas em t0, t2 e t3; em t4 foi de 2 mg/L. Em todos os horários, nas duas lagoas, abaixo de 0,6 $\mathrm{m}$ foi registrada anoxia. Na superfície da lagoa facultativa 2 foram encontradas concentrações de oxigênio dissolvido de $1 \mathrm{mg} / \mathrm{L} ; 1,2 \mathrm{mg} / \mathrm{L} ; 0,2 \mathrm{mg} / \mathrm{L}$ e 5,8 mg/L para t0, t2, t3 e t4, respectivamente (Figuras 24 e 25). 


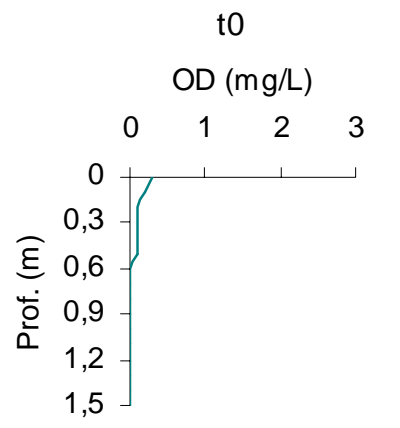

t1

t2
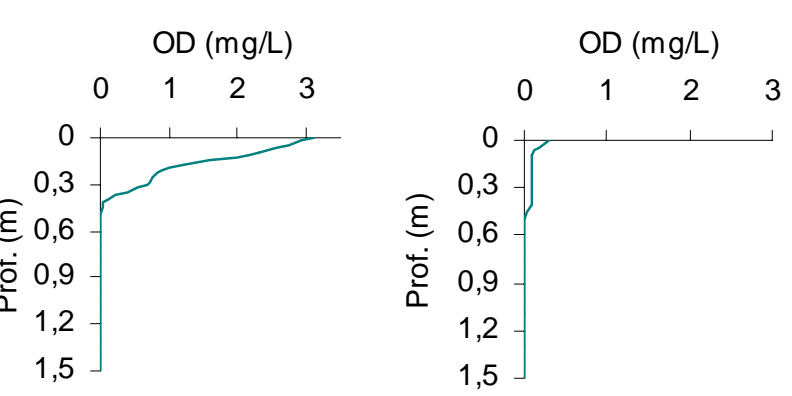

t3

t4

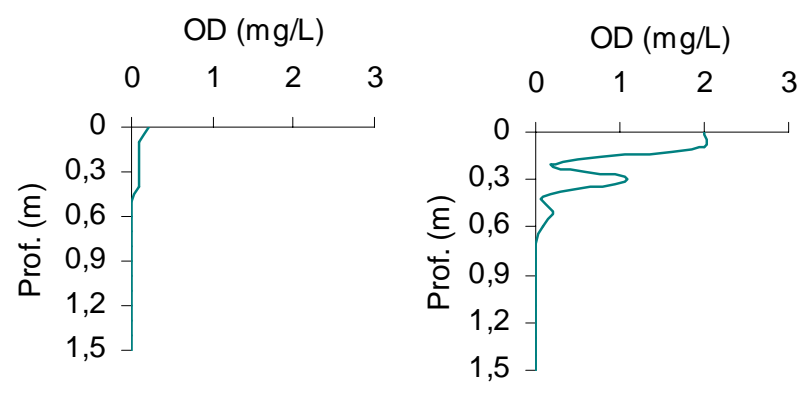

Figura 24: Perfis de oxigênio dissolvido (mg/L) obtidos na lagoa facultativa 1, da ETE de Novo Horizonte, SP no outono (maio/2002).

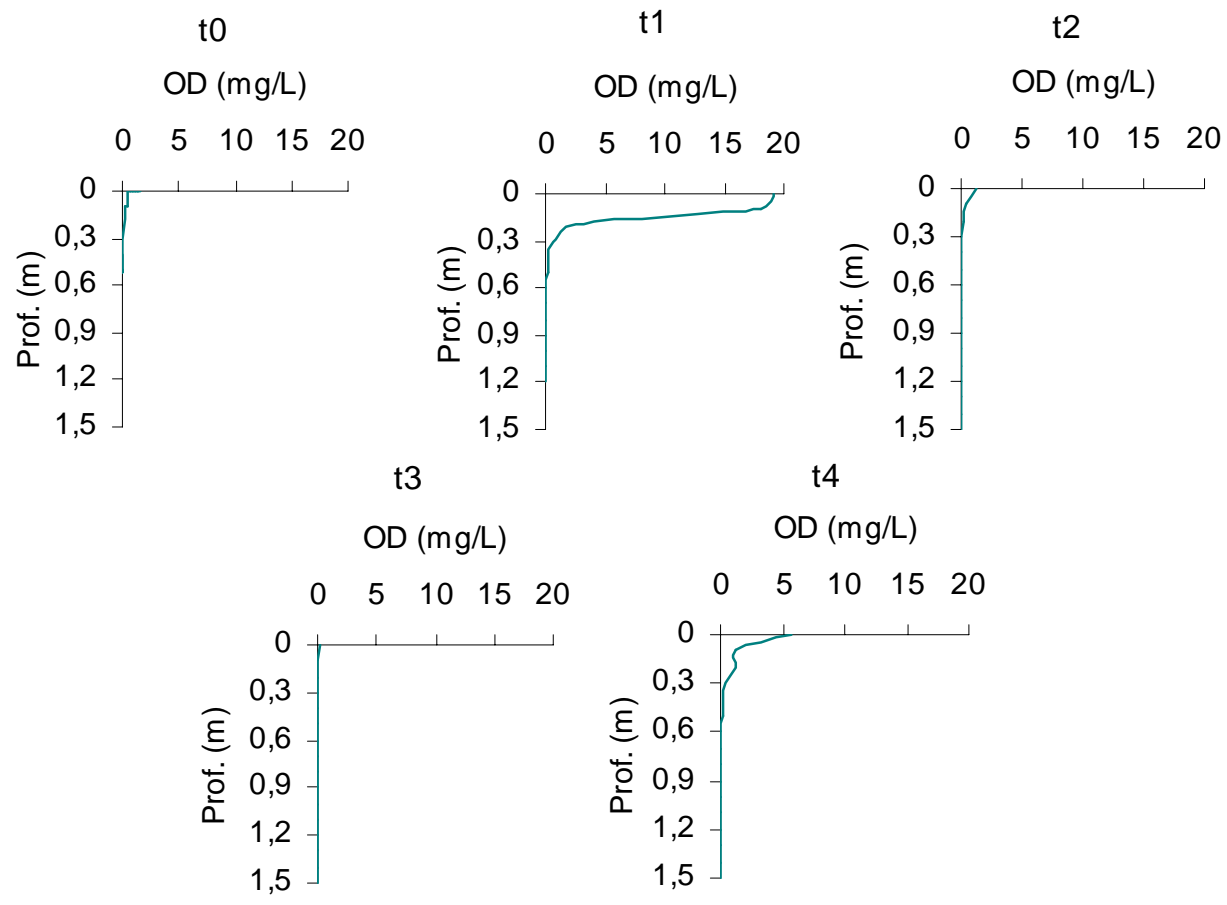

Figura 25: Perfis de oxigênio dissolvido (mg/L) obtidos na lagoa facultativa 2, da ETE de Novo Horizonte, SP, no outono (maio/2002).

No inverno, em ambas as lagoas, as concentrações de oxigênio dissolvido nos períodos noturnos (t2 e t3) e também em t0 mostraram-se muito baixas (entre 0,1 mg/L e 0,4 mg/L), mesmo na superfície. Em t4, nesta profundidade, foram registradas 9,4 mg/L em E3 e 3,2 mg/L em E4. Como ocorreu no período anterior, concentrações 
insignificantes $(0,1 \mathrm{mg} / \mathrm{L})$ ou anóxia foram encontradas abaixo de 0,6 m nas lagoas (Figuras 26 e 27).

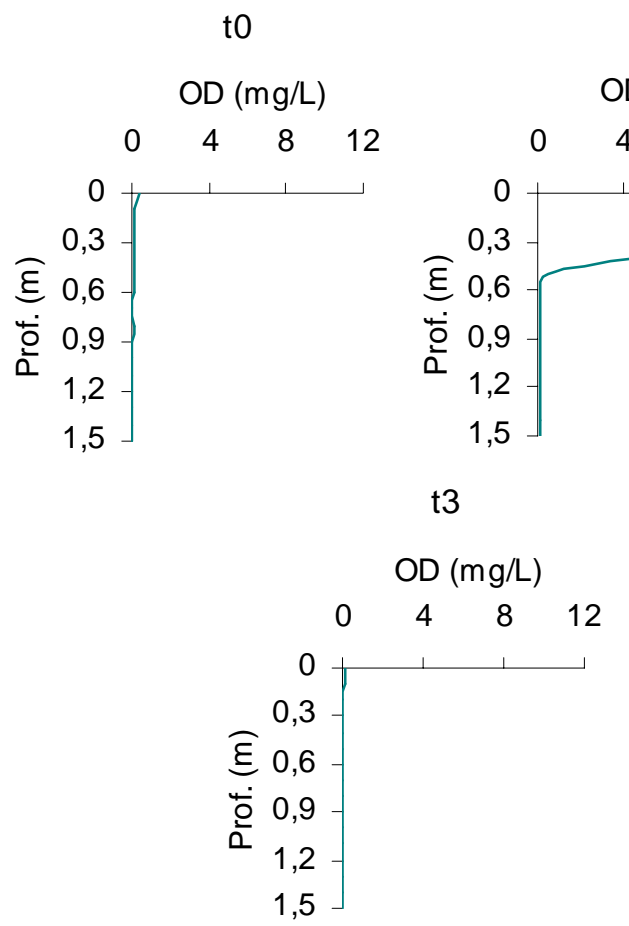

$\mathrm{t} 1$ t2 $\mathrm{D}(\mathrm{mg} / \mathrm{L})$

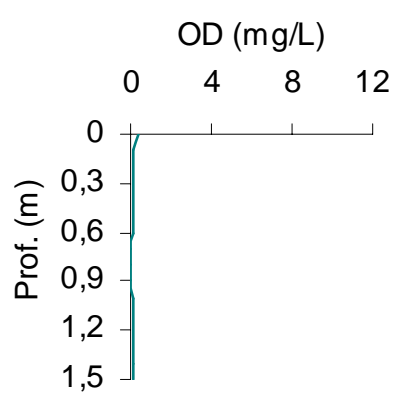

t4

Figura 26: Perfis de oxigênio dissolvido (mg/L) obtidos na lagoa facultativa 1, da ETE de Novo Horizonte, SP, no inverno (agosto/2002).

t0

t1 $\mathrm{t} 2$
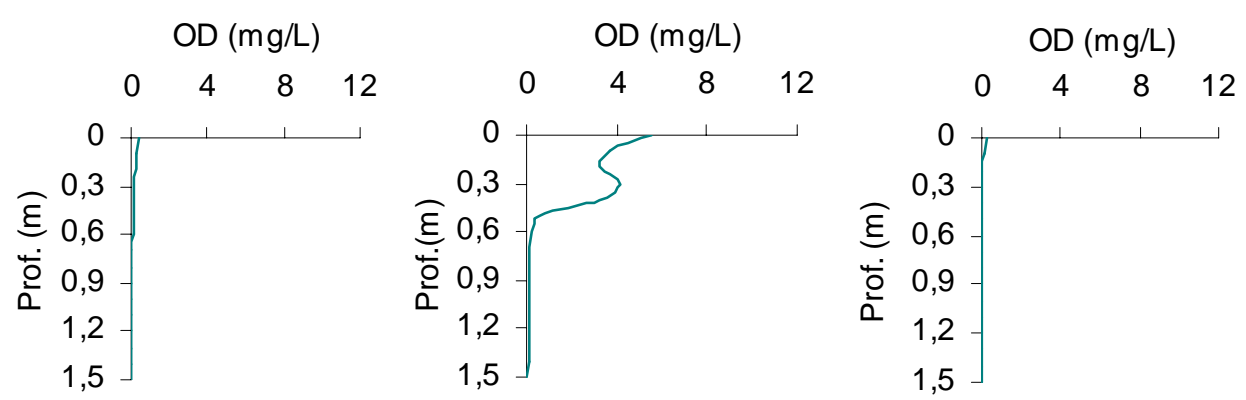

t3

t4
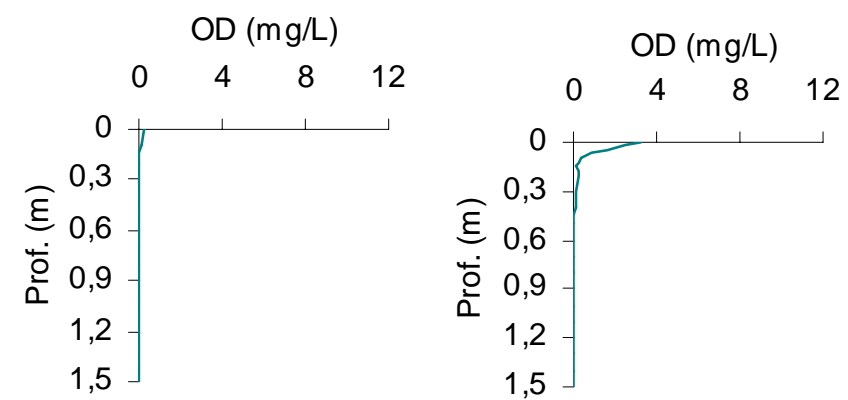

Figura 27: Perfis de oxigênio dissolvido (mg/L) obtidos na lagoa facultativa 2, da ETE de Novo Horizonte, SP, no inverno (agosto/2002) 
Um padrão muito diferente foi observado na primavera, com concentrações muito baixas na superfície das lagoas em todos os horários (de $0,1 \mathrm{mg} / \mathrm{L}$ à 0,8 mg/L) e de $0,1 \mathrm{mg} / \mathrm{L}$ até o fundo (Figuras 28 e 29).
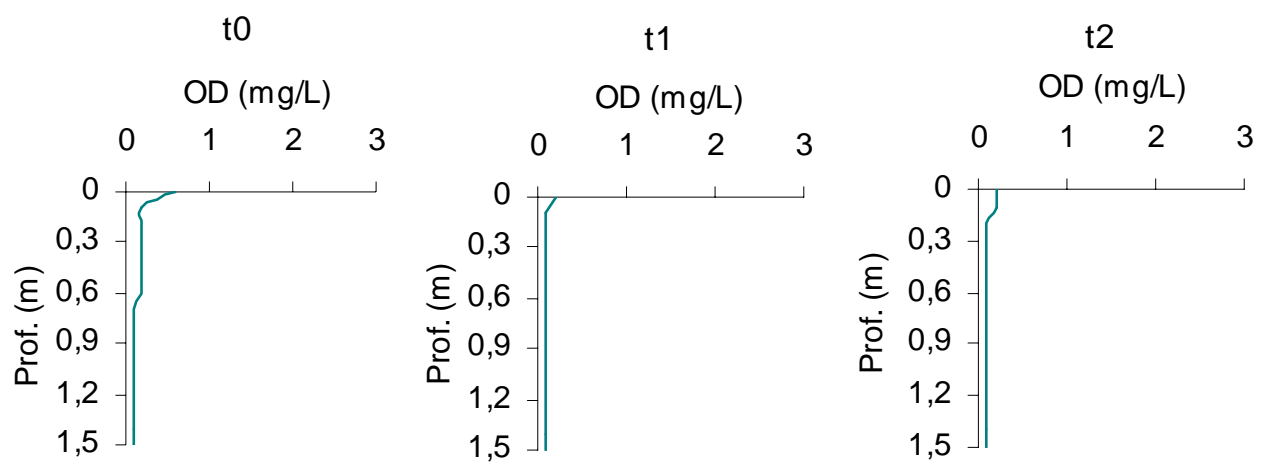

t3

t4

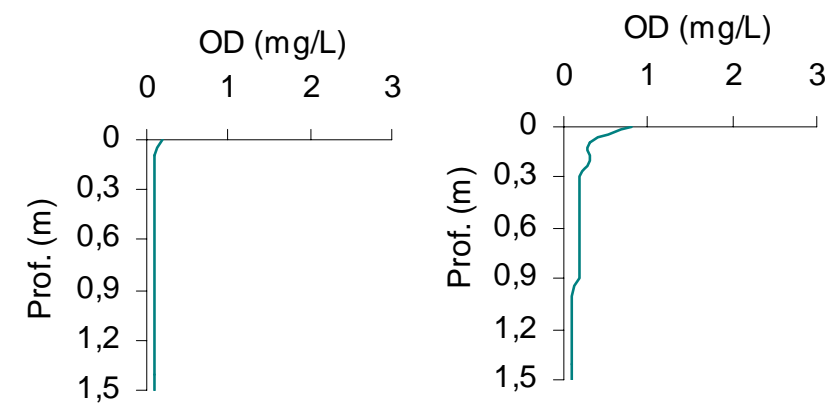

Figura 28: Perfis de oxigênio dissolvido (mg/L) obtidos na lagoa facultativa 1, da ETE de Novo Horizonte, SP, na primavera (novembro/2002).

t0

t1

t2
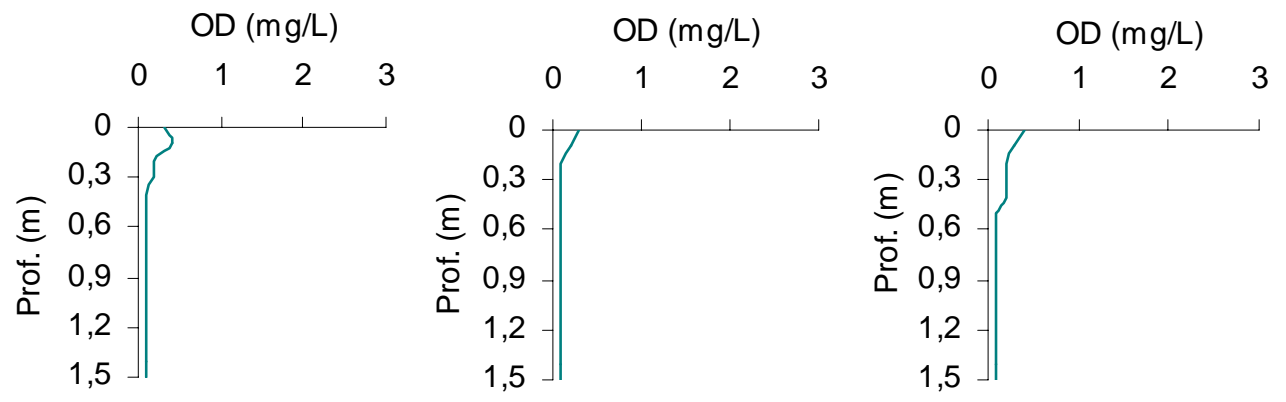

t3

t4
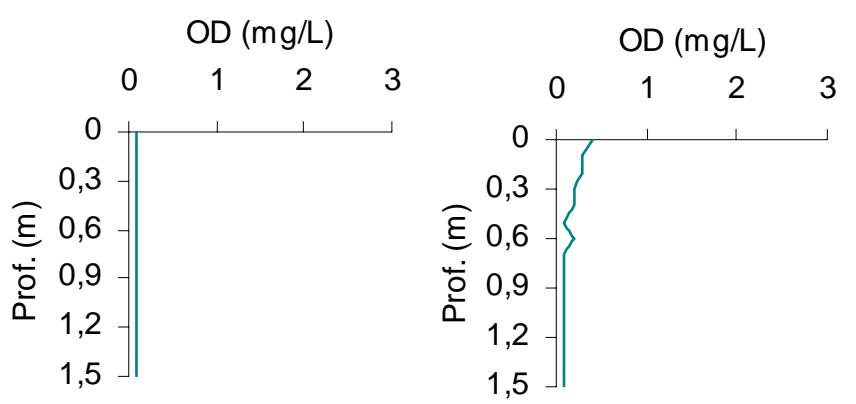

Figura 29: Perfis de oxigênio dissolvido (mg/L) obtidos na lagoa facultativa 2, da ETE de Novo Horizonte, SP, na primavera (novembro/2002). 
No verão, em t0, concentrações de 9,2 mg/L e 11,3 mg/L foram encontradas na superfície das lagoas facultativa 1 e 2, respectivamente. Baixas concentrações foram observadas na mesma profundidade da primeira lagoa estudada, em t2 e t3 (0,1 mg/L) e t4 $(0,6 \mathrm{mg} / \mathrm{L})$ e em t4, na facultativa $2(0,5 \mathrm{mg} / \mathrm{L})$. Em t3, nesta última lagoa ocorreu anoxia em toda a coluna de água (Figuras 30 e 31).

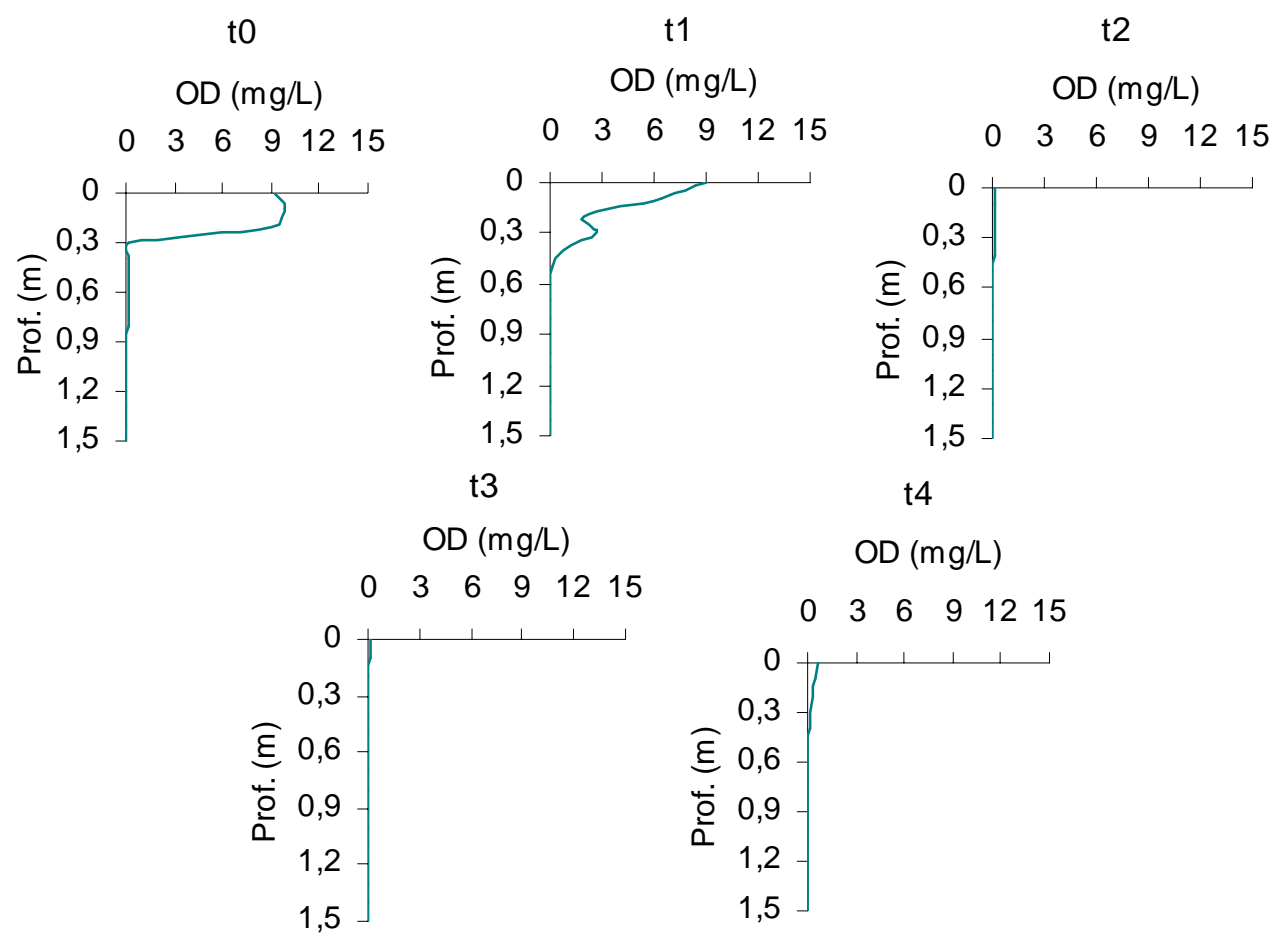

Figura 30: Perfis de oxigênio dissolvido (mg/L) obtidos na lagoa facultativa 1, da ETE de Novo Horizonte, SP, no verão (fevereiro/2003). 
t0

$\mathrm{OD}(\mathrm{mg} / \mathrm{L})$

$\begin{array}{llllll}0 & 3 & 6 & 9 & 12 & 15\end{array}$ $\mathrm{t} 1$

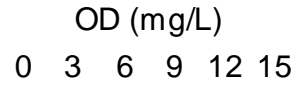

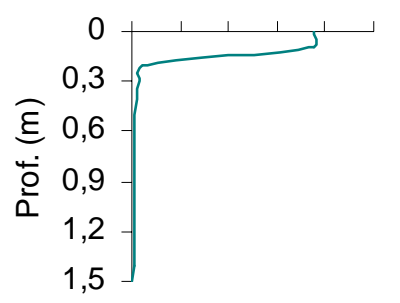

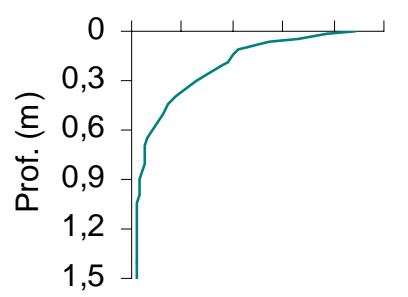

t3 t2

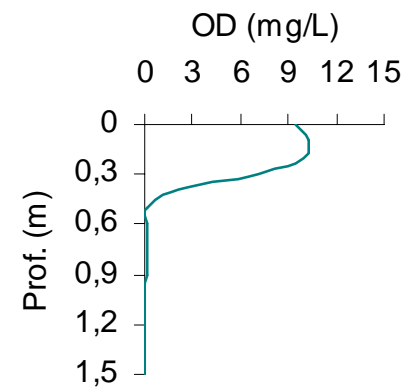

t4
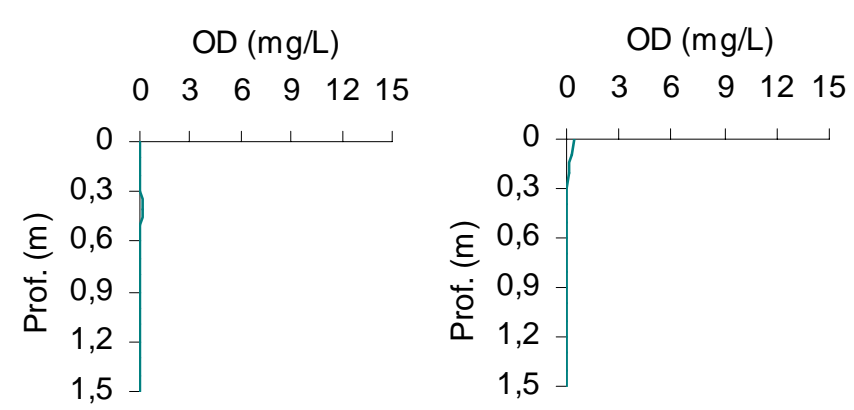

Figura 31: Perfis de oxigênio dissolvido (mg/L) obtidos na lagoa facultativa 2, da ETE de Novo Horizonte, SP, no verão (fevereiro/2003).

No efluente final foram encontradas concentrações idênticas para t0 e t4 no inverno (2 mg/L) e semelhantes na primavera $(2,4 \mathrm{mg} / \mathrm{L}$ e $2,5 \mathrm{mg} / \mathrm{L})$ e no verão $(0,8$ $\mathrm{mg} / \mathrm{L}$ e 1,1 mg/L), sendo esses os menores valores encontrados para o efluente. No outono, houve variação, 2 mg/L em t0 e 5,3 mg/L em t4 (maior concentração) (Figura 32).

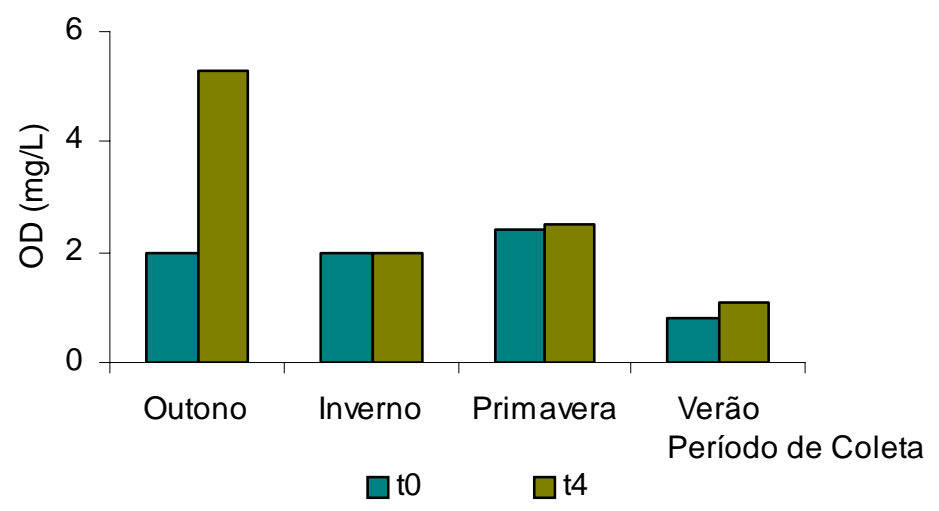

Figura 32: Concentrações de oxigênio dissolvido (mg/L) obtidas no efluente final da ETE de Novo Horizonte, SP, nos períodos estudados. 


\subsubsection{Potencial Hidrogeniônico}

Os valores mais altos de $\mathrm{pH}$ no outono, foram observados em t1 para ambas as lagoas. Na lagoa facultativa 1, o valor mínimo determinado no fundo foi de 6,0, em t4 e 7,6, o máximo registrado na superfície, em t1 (Figura 33). Na lagoa facultativa 2, o menor valor foi 7,0 observado no fundo, em t2; e o máximo foi de 9,9, encontrado na superfície de t1 (Figura 34).
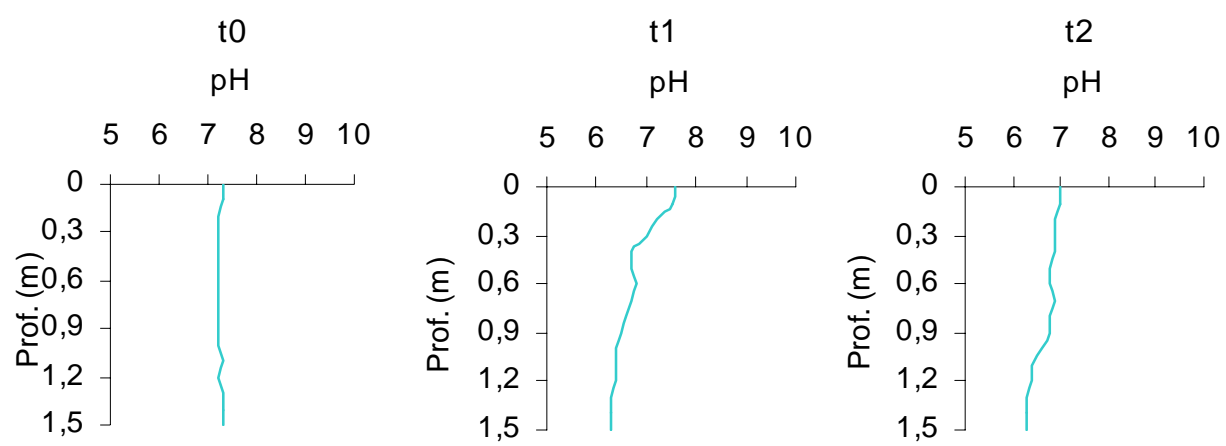

t3

t4

$\mathrm{pH}$

$\mathrm{pH}$

$\begin{array}{llllll}5 & 6 & 7 & 8 & 9 & 10\end{array}$

$\begin{array}{llllll}5 & 6 & 7 & 8 & 9 & 10\end{array}$
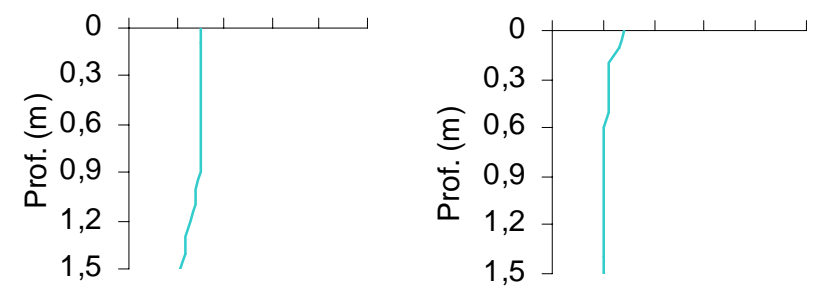

Figura 33: Perfis de $\mathrm{pH}$ obtidos na lagoa facultativa 1, da ETE de Novo Horizonte, SP, no outono (maio/2002). 


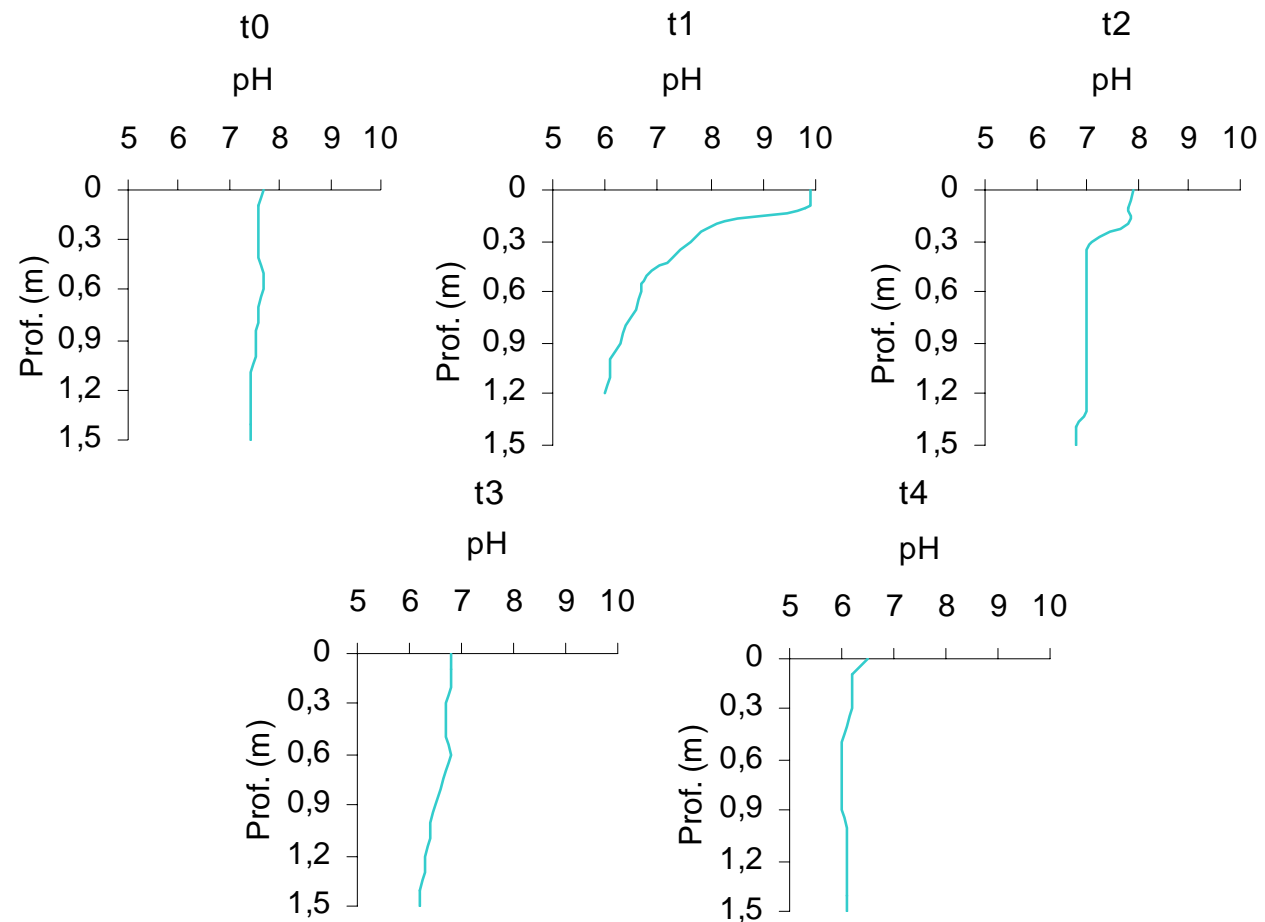

Figura 34: Perfis de pH obtidos na lagoa facultativa 2, da ETE de Novo Horizonte, SP, no outono (maio/2002).

No inverno, as lagoas também apresentaram variação de pH, com mínimo de 6,6 em t3 e máximo de 7,4 em t4, ambos na superfície da lagoa facultativa 1 (Figura 35). Na outra lagoa, o menor valor foi registrado no fundo em t1 $(6,3)$ e o maior, na superfície, em t0 $(7,6)$ (Figura 36). 


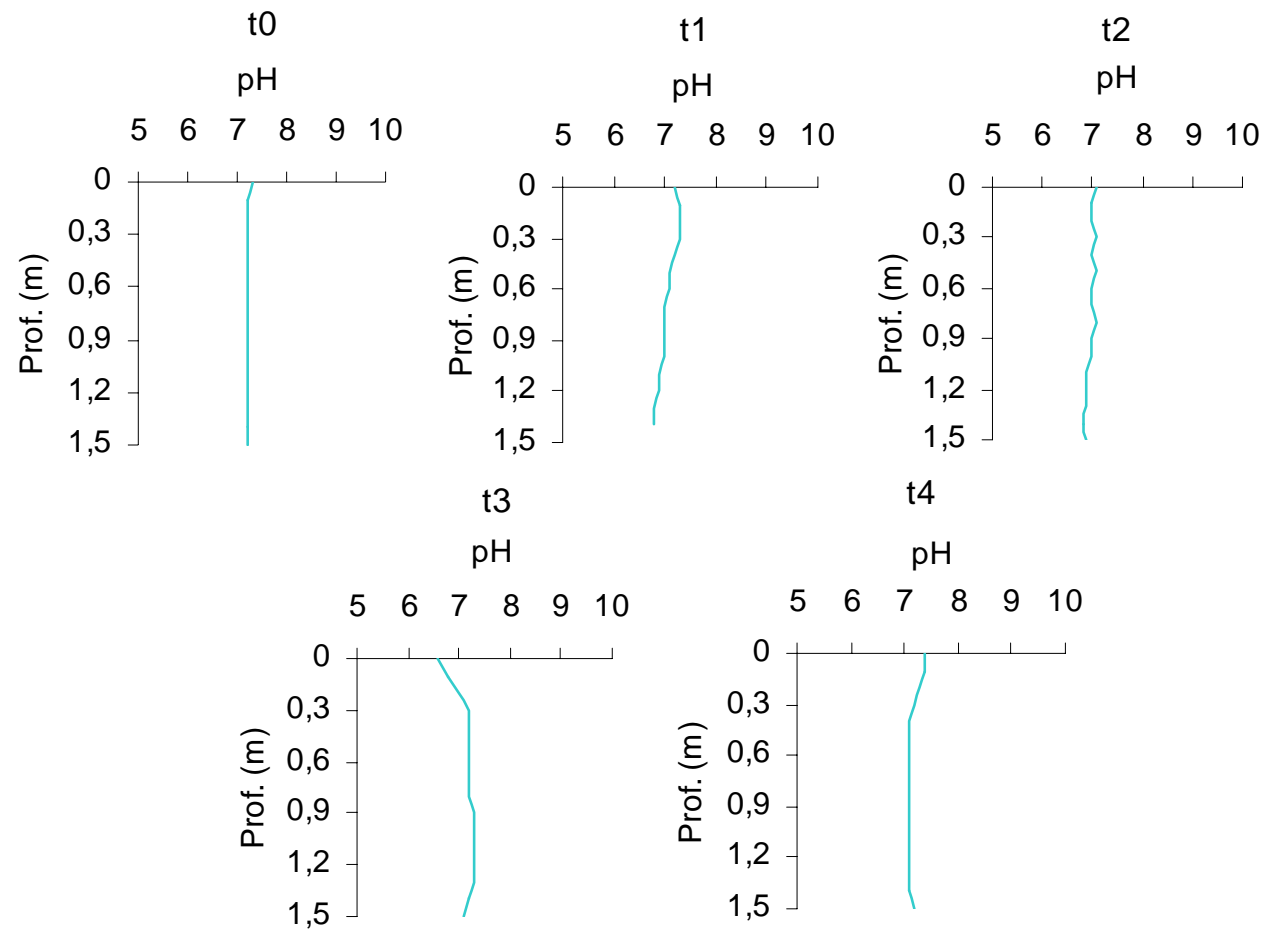

Figura 35: Perfis de $\mathrm{pH}$ obtidos na lagoa facultativa 1, da ETE de Novo Horizonte, SP, no inverno (maio/2002).

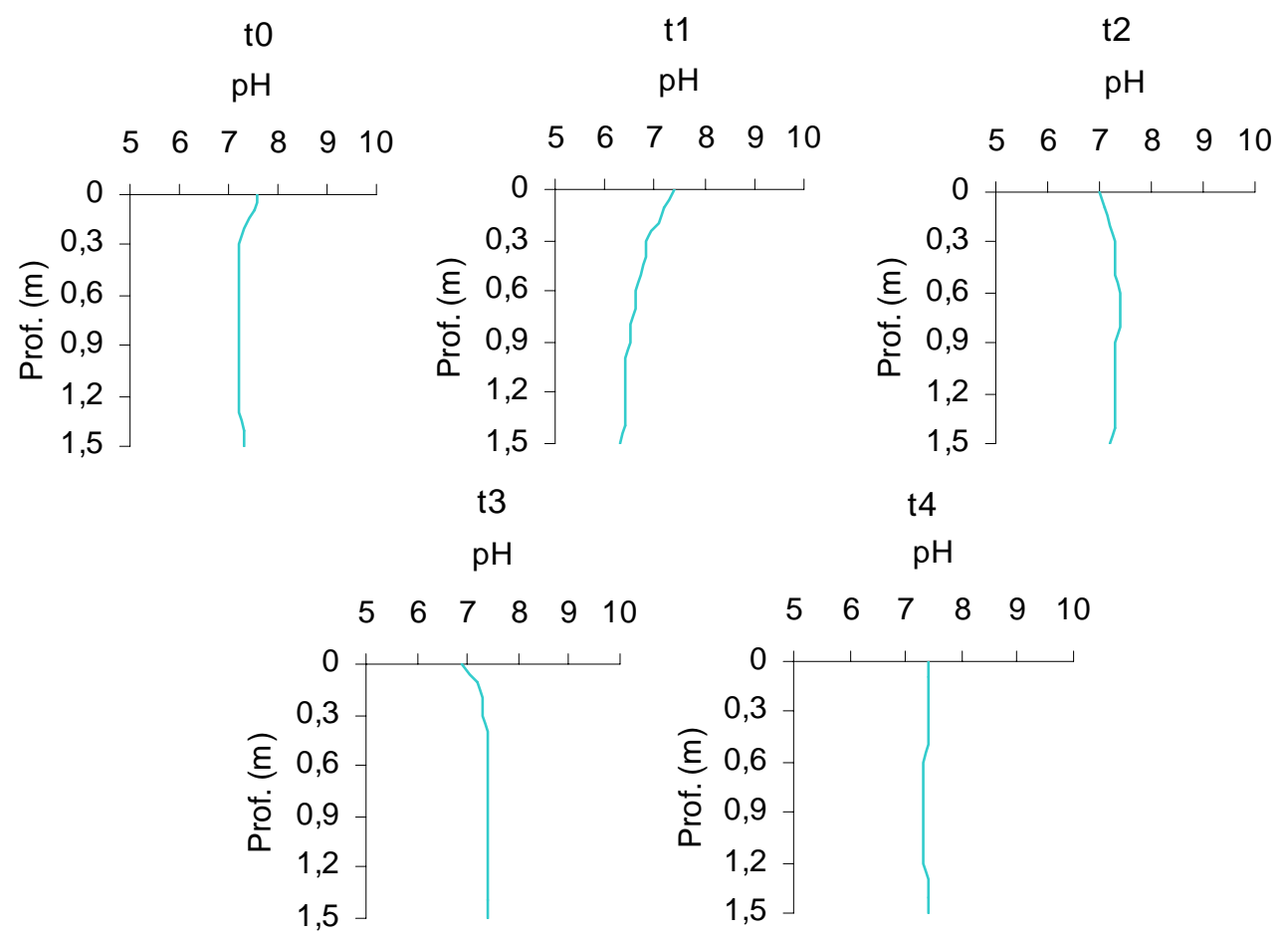

Figura 36: Perfis de pH obtidos na lagoa facultativa 2, da ETE de Novo Horizonte, SP, no inverno (maio/2002). 
Na primavera, os valores de $\mathrm{pH}$ foram muito semelhantes e constantes em toda a coluna de água, com exceção de t2 em E4, que variou de 6,9 na superfície a 7,5 no fundo. Em t0, t2 e t4, em E3, o pH foi de 7,4; e 7,5 em t3 para a mesma lagoa e em t0,

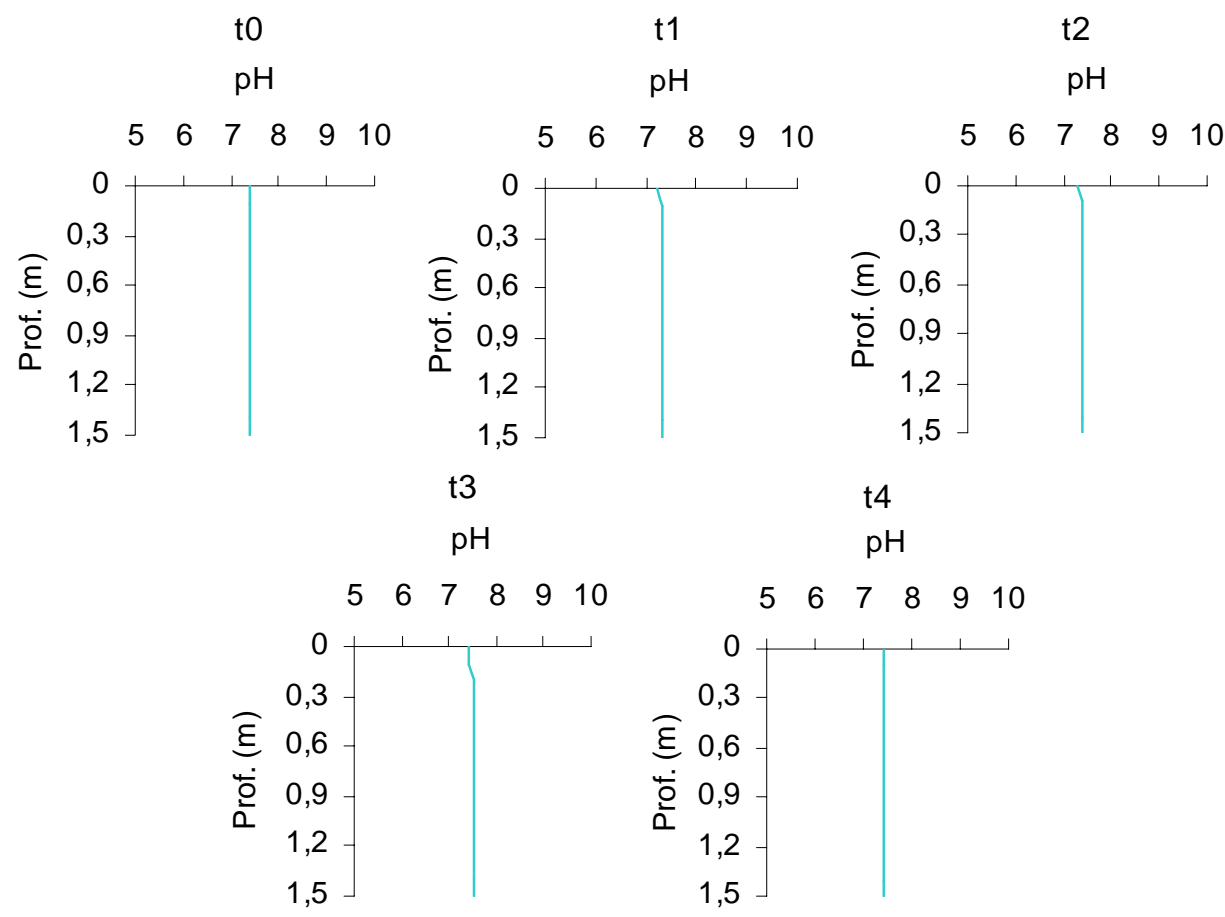

t2, t3 e t4 para a outra (Figuras 37 e 38).

Figura 37: Perfis de $\mathrm{pH}$ obtidos na lagoa facultativa 1, da ETE de Novo Horizonte, SP, na primavera (novembro/2002).

to

$\mathrm{pH}$ t1

$\mathrm{pH}$ t2

$\mathrm{pH}$

$\begin{array}{llllll}5 & 6 & 7 & 8 & 9 & 10\end{array}$
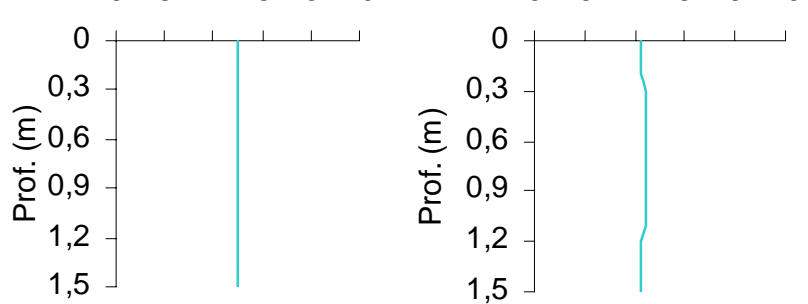

t3

$\mathrm{pH}$

t4

$\mathrm{pH}$ $\begin{array}{llllll}5 & 6 & 7 & 8 & 9 & 10\end{array}$

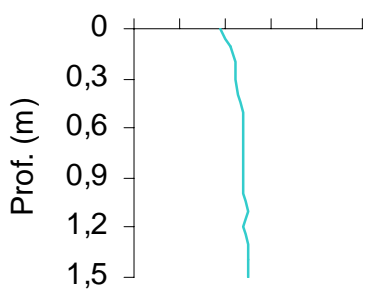

$\begin{array}{llllll}5 & 6 & 7 & 8 & 9 & 10\end{array}$
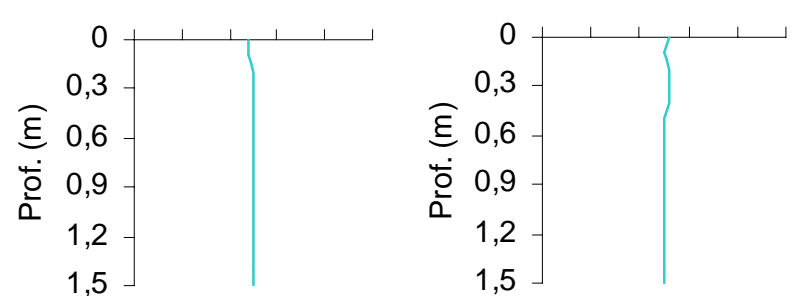

Figura 38: Perfis de $\mathrm{pH}$ obtidos na lagoa facultativa 2, da ETE de Novo Horizonte, SP, na primavera (novembro/2002). 
Em fevereiro, mês que caracterizou o verão, o maior $\mathrm{pH}$ para a lagoa facultativa 1 foi de 8,5, encontrado na superfície em t0; e o menor foi de 6,9, no fundo para o mesmo horário, sendo esta a maior oscilação na coluna de água para o período (Figura 39). Na lagoa facultativa 2, o pH mínimo foi de 6,7 foi registrado no fundo em $\mathrm{t} 1$; e o máximo foi de 8,7, na superfície, em t2 (Figura 40).

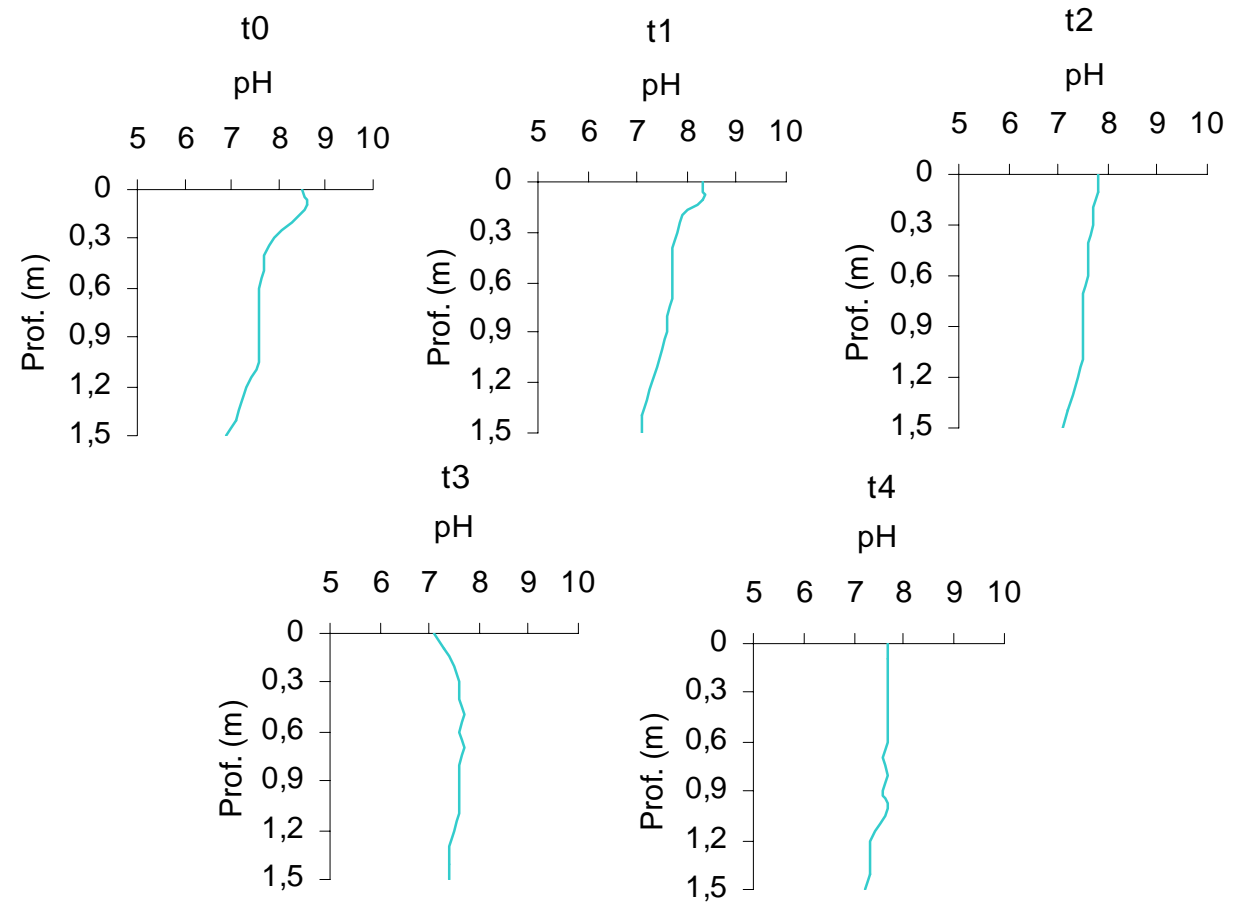

Figura 39: Perfis de $\mathrm{pH}$ obtidos na lagoa facultativa 1, da ETE de Novo Horizonte, SP, no verão (fevereiro/2003). 

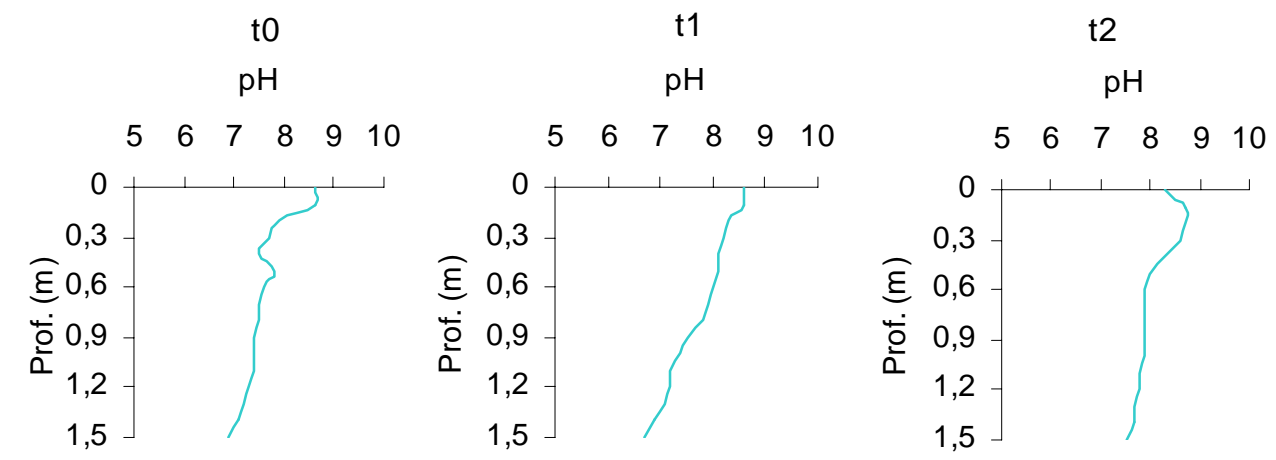

t3

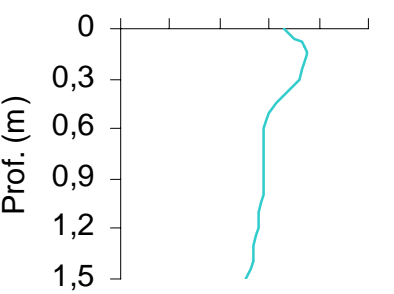

$\mathrm{pH}$

t4

$\mathrm{pH}$

$\begin{array}{llllll}5 & 6 & 7 & 8 & 9 & 10\end{array}$

$\begin{array}{llllll}5 & 6 & 7 & 8 & 9 & 10\end{array}$
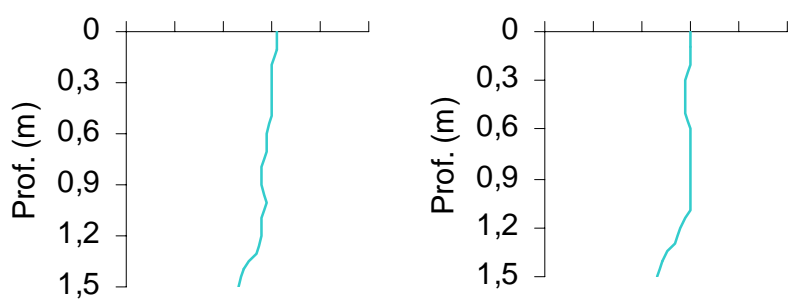

Figura 40: Perfis de pH obtidos na lagoa facultativa 2, da ETE de Novo Horizonte, SP, no verão (fevereiro/2003).

O efluente final apresentou valores idênticos de $\mathrm{pH}$ para t0 e t4 no inverno $(7,6)$ e na primavera $(7,5)$. No verão, os valores foram 7,6 em t0 e 7,9 em t4. No outono houve a maior variação entre t0 $(8,0)$ e t4 $(6,9)$ (Figura 41).

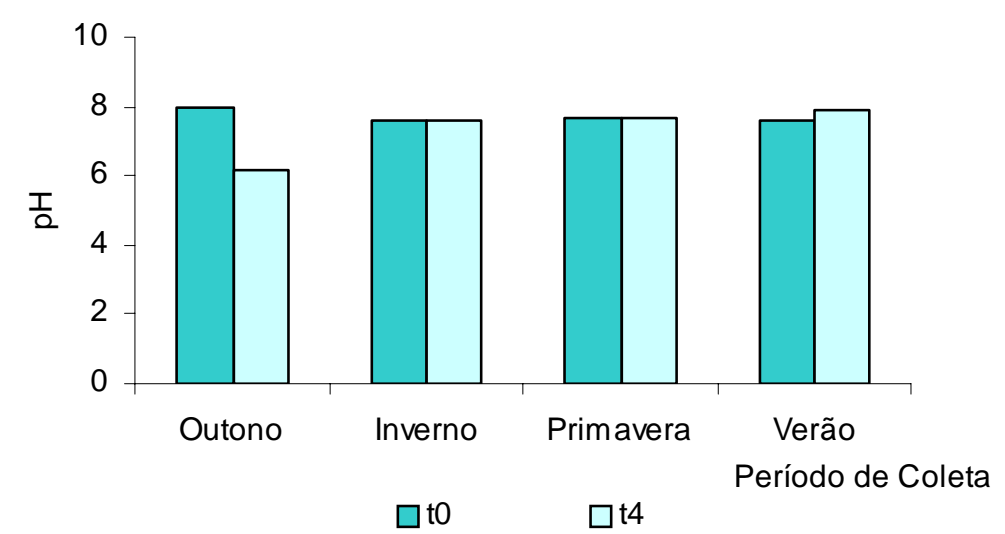

Figura 41: Valores de pH obtidos no efluente final da ETE de Novo Horizonte, SP, nos períodos estudados.

\subsubsection{Nutrientes Totais e Nutrientes Inorgânicos Dissolvidos}

As concentrações de fósforo total no outono, nas diferentes profundidades amostradas das duas lagoas,oscilaram entre 15,1 mg/L na superfície de E4 em t2 a 18,9 $\mathrm{mg} / \mathrm{L}$ a $0,7 \mathrm{~m}$ de profundidade da mesma lagoa em t0. Para o nitrogênio total, na superfície da segunda lagoa facultativa, em $\mathrm{t} 3$, foi observada a maior concentração entre 
todos os períodos estudados, muito superior que as demais (100,5 mg/L). Concentrações mínimas de nitrito, de 0,001 mg/L, foram registradas em diversos horários e profundidades; e a máxima foi de $0,07 \mathrm{mg} / \mathrm{L}$, inclusive para todas as épocas estudadas, foi observada a $0,7 \mathrm{~m}$ da lagoa facultativa 2 , em t0. O nitrato mostrou pouca variação, com concentrações na faixa de 2,0 mg/L. O mesmo foi observado para o nitrogênio amoniacal, que oscilou de 29,7 mg/L, na superfície de E4 a 37,2 mg/L, encontrado na mesma profundidade da outra lagoa, ambos em t2. Para o ortofosfato, o valor máximo foi registrado a 0,7m de profundidade da primeira lagoa facultativa, em t3 (5,13 mg/L). Os resultados obtidos para os nutrientes totais e dissolvidos em todas as estações e profundidades estudadas no outono, podem ser observados na Tabela 4. 
Tabela 4: Concentrações (mg/L) dos nutrientes totais, fósforo (PT) e nitrogênio (NT) e dos nutrientes dissolvidos, nitrito $\left(\mathrm{NO}_{2}\right)$, nitrato $\left(\mathrm{NO}_{3}\right)$, nitrogênio amoniacal (N-amon.) e ortofosfato $\left(\mathrm{PO}_{4}\right)$, nas estações de coleta da ETE de Novo Horizonte, SP, no outono (maio/2002).

\begin{tabular}{|c|c|c|c|c|c|c|c|}
\hline & \multicolumn{2}{|c|}{ Nutrientes Totais } & \multicolumn{4}{|c|}{ Nutrientes Dissolvidos } \\
\hline $\begin{array}{l}\text { Horário } \\
\text { de Coleta }\end{array}$ & Estação & PT & NTK & $\mathrm{NO}_{2}$ & $\mathrm{NO}_{3}$ & N-amon. & $\mathrm{PO}_{4}$ \\
\hline \multirow{7}{*}{ t0 } & E3S & 17,7 & 47,3 & 0,002 & 2,5 & 33,9 & 0,03 \\
\hline & E3M & 18,1 & 49,0 & 0,012 & 2,8 & 34,1 & 0,02 \\
\hline & E3F & 17,4 & 48,3 & 0,002 & 2,6 & 33,1 & 0,15 \\
\hline & E4S & 18,6 & 46,2 & 0,005 & 2,4 & 31,2 & 0,21 \\
\hline & E4M & 18,9 & 48,0 & 0,007 & 2,2 & 31,2 & 0,02 \\
\hline & $\mathrm{E} 4 \mathrm{~F}$ & 18,7 & 47,3 & 0,006 & 2,4 & 31,6 & 0,12 \\
\hline & E5 & 18,8 & 48,4 & 0,014 & 1,9 & 31,6 & 0,40 \\
\hline \multirow[t]{6}{*}{$\mathrm{t} 1$} & E3S & 17,1 & 52,1 & 0,006 & 2,5 & 34,1 & 0,08 \\
\hline & E3M & 16,8 & 57,0 & 0,002 & 2,3 & 33,2 & 0,16 \\
\hline & E3F & 16,5 & 53,2 & 0,002 & 1,6 & 34,8 & 0,10 \\
\hline & E4S & 17,1 & 51,1 & 0,008 & 2,3 & 33,1 & 0,03 \\
\hline & E4M & 17,0 & 58,6 & 0,003 & 2,0 & 32,5 & 0,16 \\
\hline & E4F & 16,8 & 59,0 & 0,003 & 2,0 & 33,6 & 0,25 \\
\hline \multirow[t]{6}{*}{$\mathrm{t} 2$} & E3S & 16,4 & 45,2 & 0,001 & 2,3 & 37,2 & 2,04 \\
\hline & E3M & 16,3 & 49,0 & 0,003 & 2,1 & 33,0 & 2,19 \\
\hline & E3F & 16,3 & 49,5 & 0,001 & 2,3 & 35,1 & 3,07 \\
\hline & E4S & 15,1 & 45,2 & 0,020 & 1,9 & 29,7 & 0,66 \\
\hline & E4M & 16,1 & 47,8 & 0,006 & 2,1 & 32,5 & 0,79 \\
\hline & E4F & 16,5 & 52,7 & 0,001 & 2,2 & 33,0 & 1,96 \\
\hline \multirow[t]{6}{*}{$\mathrm{t} 3$} & E3S & 16,4 & 54,8 & 0,003 & 2,4 & 36,0 & 4,97 \\
\hline & E3M & 16,1 & 47,3 & 0,003 & 2,2 & 36,8 & 5,13 \\
\hline & E3F & 17,0 & 47,3 & 0,003 & 2,3 & 34,8 & 4,20 \\
\hline & E4S & 16,9 & 100,5 & 0,003 & 2,5 & 33,2 & 4,28 \\
\hline & E4M & 16,3 & 45,7 & 0,003 & 2,3 & 34,7 & 2,90 \\
\hline & E4F & 17,0 & 59,0 & 0,003 & 2,1 & 33,7 & 3,64 \\
\hline \multirow[t]{7}{*}{$\mathrm{t} 4$} & E3S & 17,3 & 49,5 & 0,002 & 2,1 & 35,2 & 2,21 \\
\hline & E3M & 16,7 & 54,8 & 0,001 & 2,3 & 33,9 & 2,91 \\
\hline & E3F & 16,6 & 47,8 & 0,001 & 2,2 & 34,5 & 3,19 \\
\hline & E4S & 17,9 & 47,3 & 0,001 & 2,0 & 33,2 & 2,07 \\
\hline & E4M & 17,8 & 45,2 & 0,001 & 2,0 & 32,8 & 2,55 \\
\hline & E4F & 16,9 & 45,2 & 0,002 & 2,1 & 33,1 & 2,24 \\
\hline & E5 & 17,5 & 49,5 & 0,002 & 2,1 & 34,7 & 2,02 \\
\hline
\end{tabular}

No inverno, a maior concentração de fósforo total foi obtida na superfície da segunda lagoa facultativa, em t0 $(19,8 \mathrm{mg} / \mathrm{L})$; em contraste, todos os valores em $\mathrm{t} 4$ mostraram-se bem abaixo dos encontrados nos outros horários desse período (entre 6,4 mg/L e 13,5 mg/L). O nitrogênio, apresentou valor máximo de $80 \mathrm{mg} / \mathrm{L}$ a 1,5 m na lagoa facultativa 1 , em t0 e o nitrito, a $0,7 \mathrm{~m}$ de profundidade, na facultativa 2 , em $\mathrm{t} 1$ $(0,032 \mathrm{mg} / \mathrm{L})$. A concentração de nitrato oscilou entre $1,8 \mathrm{mg} / \mathrm{L}$, encontrada a $0,7 \mathrm{~m}$ de 
E4, em t0 a 5,1 mg/L, obtido na superfície de E3, em t1. O nitrogênio amoniacal apresentou sua maior concentração na superfície da primeira lagoa estudada, em t1 (48 $\mathrm{mg} / \mathrm{L}$ ), sendo este o valor máximo entre todos os períodos. O ortofosfato variou de 0,2 mg/L,valor mínimo registrado a $0 \mathrm{~m}$ de E3, no primeiro horário a 3,46 mg/L, obtido no fundo da mesma lagoa, em t3 (Tabela 5).

Tabela 5: Concentrações (mg/L) dos nutrientes totais, fósforo (PT) e nitrogênio (NT) e dos nutrientes dissolvidos, nitrito $\left(\mathrm{NO}_{2}\right)$, nitrato $\left(\mathrm{NO}_{3}\right)$, nitrogênio amoniacal (N-amon.) e ortofosfato $\left(\mathrm{PO}_{4}\right)$, nas estações de coleta da ETE de Novo Horizonte, SP, no inverno (agosto/2002).

\begin{tabular}{|c|c|c|c|c|c|c|c|}
\hline \multirow[b]{2}{*}{$\begin{array}{l}\text { Horário } \\
\text { de Coleta }\end{array}$} & \multirow[b]{2}{*}{ Estação } & \multicolumn{2}{|c|}{ Nutrientes Totais } & \multicolumn{4}{|c|}{ Nutrientes Dissolvidos } \\
\hline & & PT & NTK & $\mathrm{NO}_{2}$ & $\mathrm{NO}_{3}$ & $\mathrm{~N}$-amon. & $\mathrm{PO}_{4}$ \\
\hline \multirow[t]{7}{*}{ t0 } & E3S & 18,8 & 64 & 0,007 & 2,2 & 33 & 0,20 \\
\hline & E3M & 18,0 & 71 & 0,009 & 2,4 & 34 & 0,69 \\
\hline & E3F & 17,7 & 80 & 0,005 & 2,0 & 33 & 0,57 \\
\hline & E4S & 19,8 & 54 & 0,006 & 1,9 & 34 & 1,66 \\
\hline & E4M & 19,0 & 54 & 0,005 & 1,8 & 35 & 1,72 \\
\hline & $\mathrm{E} 4 \mathrm{~F}$ & 19,1 & 59 & 0,019 & 3,4 & 35 & 1,67 \\
\hline & E5 & 18,8 & 60 & 0,024 & 3,7 & 33 & 1,86 \\
\hline \multirow[t]{6}{*}{$\mathrm{t} 1$} & E3S & 17,7 & 65 & 0,022 & 5,1 & 48 & 0,48 \\
\hline & E3M & 17,0 & 62 & 0,024 & 4,7 & 32 & 0,41 \\
\hline & E3F & 16,4 & 64 & 0,007 & 2,7 & 26 & 0,29 \\
\hline & E4S & 15,5 & 68 & 0,027 & 4,2 & 35 & 0,74 \\
\hline & E4M & 14,8 & 59 & 0,032 & 4,9 & 25 & 0,64 \\
\hline & E4F & 14,7 & 56 & 0,020 & 3,5 & 35 & 0,57 \\
\hline \multirow[t]{6}{*}{$\mathrm{t} 2$} & E3S & 16,4 & 55 & 0,005 & 2,2 & 34 & 1,61 \\
\hline & E3M & 15,3 & 53 & 0,006 & 2,2 & 34 & 0,75 \\
\hline & E3F & 15,7 & 57 & 0,015 & 3,4 & 38 & 0,66 \\
\hline & E4S & 16,0 & 51 & 0,017 & 3,8 & 37 & 0,71 \\
\hline & E4M & 14,4 & 49 & 0,023 & 3,9 & 34 & 0,77 \\
\hline & E4F & 15,5 & 58 & 0,014 & 3,0 & 36 & 3,27 \\
\hline \multirow[t]{6}{*}{ t3 } & E3S & 15,2 & 46 & 0,011 & 3,3 & 19 & 3,26 \\
\hline & E3M & 14,3 & 39 & 0,012 & 3,0 & 33 & 3,18 \\
\hline & E3F & 17,9 & 47 & 0,015 & 3,5 & 32 & 3,46 \\
\hline & E4S & 19,2 & 48 & 0,019 & 3,6 & 34 & 3,19 \\
\hline & E4M & 18,3 & 45 & 0,016 & 3,3 & 29 & 3,27 \\
\hline & E4F & 19,6 & 37 & 0,018 & 3,3 & 26 & 3,12 \\
\hline \multirow[t]{7}{*}{$\mathrm{t} 4$} & E3S & 13,5 & 63 & 0,022 & 4,8 & 33 & 0,80 \\
\hline & E3M & 6,4 & 60 & 0,016 & 3,5 & 32 & 1,46 \\
\hline & E3F & 9,1 & 46 & 0,017 & 3,6 & 34 & 1,83 \\
\hline & E4S & 9,6 & 48 & 0,016 & 2,6 & 33 & 1,89 \\
\hline & E4M & 9,6 & 41 & 0,016 & 2,5 & 25 & 2,24 \\
\hline & E4F & 9,1 & 48 & 0,016 & 2,6 & 30 & 0,23 \\
\hline & E5 & 9,7 & 54 & 0,030 & 4,9 & 37 & 0,78 \\
\hline
\end{tabular}


As concentrações de fósforo apresentaram-se bem próximas, entre 16,0 mg/L e 19,0 mg/L. Na primavera, essas concentrações variaram pouco nas estações e horários de coleta, entre $18 \mathrm{mg} / \mathrm{L}$ e $19 \mathrm{mg} / \mathrm{L}$. Para o nitrogênio, o valor máximo do período foi registrado na superfície da lagoa facultativa 1 , em t0 e t1 e na mesma profundidade da outra lagoa, em t3 e t4. Concentrações mínimas de nitrito $(0,001 \mathrm{mg} / \mathrm{L})$ foram observadas em diversos horários e profundidades: na superfície de E3, em t1 e t4, a 1,5 m de profundidade, em t1 e a 1,5 m e 0,7m da outra lagoa, em t1 e t3, respectivamente. O valor máximo foi observado no fundo da última lagoa, no primeiro horário de coleta (0,035 mg/L). A maior concentração de nitrato para essa e para as demais épocas de coleta foi de $5,8 \mathrm{mg} / \mathrm{L}$, obtido a $1,5 \mathrm{~m}$ de E4, em t0. As concentrações máximas de nitrogênio amoniacal e ortofosfato foram 37,0 mg/L e 2,97 mg/L, respectivamente; o primeiro encontrado no fundo da lagoa facultativa 1 , em t2 e t3 e a 0,7 m neste último horário e a $0 \mathrm{~m}$ da outra lagoa, em t2; sendo que o segundo foi observado na mesma lagoa e profundidade, mas em t3 (Tabela 6). 
Tabela 6: Concentrações (mg/L) dos nutrientes totais, fósforo (PT) e nitrogênio (NT) e dos nutrientes dissolvidos, nitrito $\left(\mathrm{NO}_{2}\right)$, nitrato $\left(\mathrm{NO}_{3}\right)$, nitrogênio amoniacal (N-amon.) e ortofosfato $\left(\mathrm{PO}_{4}\right)$, nas estações de coleta da ETE de Novo Horizonte, SP, na primavera (novembro/2002).

\begin{tabular}{|c|c|c|c|c|c|c|c|}
\hline \multicolumn{2}{|c|}{ (2) } & \multicolumn{2}{|c|}{ Nutrientes Totais } & \multicolumn{4}{|c|}{ Nutrientes Dissolvidos } \\
\hline $\begin{array}{c}\text { Horário } \\
\text { de Coleta }\end{array}$ & Estação & PT & NTK & $\mathrm{NO}_{2}$ & $\mathrm{NO}_{3}$ & N-amon. & $\mathbf{P O}_{4}$ \\
\hline \multirow{7}{*}{ t0 } & E3S & 18,2 & 49 & 0,010 & 2,6 & 34 & 0,24 \\
\hline & E3M & 19,0 & 47 & 0,011 & 2,6 & 34 & 0,10 \\
\hline & E3F & 18,9 & 48 & 0,013 & 3,1 & 35 & 0,12 \\
\hline & E4S & 18,5 & 46 & 0,004 & 2,6 & 36 & 0,71 \\
\hline & E4M & 19,1 & 46 & 0,004 & 2,5 & 35 & 0,70 \\
\hline & $\mathrm{E} 4 \mathrm{~F}$ & 18,7 & 47 & 0,035 & 5,8 & 34 & 0,70 \\
\hline & E5 & 18,6 & 47 & 0,006 & 2,1 & 35 & 0,59 \\
\hline \multirow[t]{6}{*}{$\mathrm{t} 1$} & E3S & 18,0 & 49 & 0,001 & 2,0 & 36 & 1,09 \\
\hline & E3M & 18,1 & 48 & 0,003 & 2,2 & 35 & 0,67 \\
\hline & E3F & 18,5 & 48 & 0,001 & 2,0 & 36 & 1,42 \\
\hline & E4S & 18,5 & 44 & 0,002 & 1,9 & 35 & 0,56 \\
\hline & E4M & 18,9 & 44 & 0,002 & 1,8 & 36 & 0,53 \\
\hline & E4F & 19,0 & 47 & 0,001 & 1,8 & 34 & 0,76 \\
\hline \multirow[t]{6}{*}{$\mathrm{t} 2$} & E3S & 18,1 & 45 & 0,003 & 2,4 & 33 & 2,49 \\
\hline & E3M & 18,3 & 46 & 0,002 & 2,2 & 34 & 1,85 \\
\hline & E3F & 18,6 & 47 & 0,002 & 2,2 & 37 & 1,82 \\
\hline & E4S & 18,0 & 47 & 0,003 & 2,4 & 37 & 2,86 \\
\hline & E4M & 18,9 & 45 & 0,003 & 2,4 & 32 & 2,56 \\
\hline & E4F & 18,6 & 47 & 0,004 & 2,1 & 35 & 2,24 \\
\hline \multirow[t]{6}{*}{$\mathrm{t} 3$} & E3S & 18,0 & 48 & 0,004 & 2,4 & 36 & 2,97 \\
\hline & E3M & 18,4 & 48 & 0,002 & 2,1 & 37 & 2,85 \\
\hline & E3F & 18,0 & 46 & 0,014 & 3,3 & 37 & 1,20 \\
\hline & E4S & 18,3 & 49 & 0,003 & 2,2 & 35 & 2,96 \\
\hline & E4M & 18,3 & 47 & 0,001 & 2,0 & 34 & 2,61 \\
\hline & E4F & 19,0 & 45 & 0,006 & 2,5 & 36 & 2,65 \\
\hline \multirow[t]{7}{*}{$\mathrm{t} 4$} & E3S & 19,1 & 33 & 0,001 & 2,3 & 21 & 1,42 \\
\hline & E3M & 18,7 & 48 & 0,002 & 2,3 & 36 & 1,35 \\
\hline & E3F & 18,9 & 41 & 0,004 & 2,4 & 27 & 2,86 \\
\hline & E4S & 19,5 & 49 & 0,004 & 2,3 & 36 & 1,06 \\
\hline & E4M & 19,2 & 40 & 0,005 & 2,2 & 30 & 0,97 \\
\hline & E4F & 19,5 & 46 & 0,007 & 2,3 & 31 & 1,02 \\
\hline & E5 & 19,5 & 43 & 0,006 & 2,4 & 35 & 1,00 \\
\hline
\end{tabular}

No verão, ocorreram as maiores oscilações nas concentrações de fósforo, com relação aos valores mínimos e máximos de todos os períodos de estudo: $6 \mathrm{mg} / \mathrm{L}$, encontrado a $0,7 \mathrm{~m}$ na lagoa facultativa 2 , em t0 e $26,1 \mathrm{mg} / \mathrm{L}$, obtido na superfície da outra lagoa, em t3. A maior concentração de nitrogênio foi registrada a $0 \mathrm{~m}$ da lagoa facultativa 1, em t3 (54 mg/L). Os valores máximos de nitrito, nitrato e nitrogênio amoniacal foram de 0,048 mg/L, 4,4 mg/L e 36,0 mg/L, respectivamente. O primeiro, 
observado no efluente final em t4; o segundo e o último, encontrados na superfície da primeira lagoa amostrada em t3. A concentração de ortofosfato, comparada à obtida nos demais períodos, sofreu pouca variação, entre $2,32 \mathrm{mg} / \mathrm{L}$, no fundo de E3 no primeiro horário de estudo a 3,94, no efluente final no último horário (Tabela 7).

Tabela 7: Concentrações (mg/L) dos nutrientes totais, fósforo (PT) e nitrogênio (NT) e dos nutrientes dissolvidos, nitrito $\left(\mathrm{NO}_{2}\right)$, nitrato $\left(\mathrm{NO}_{3}\right)$, nitrogênio amoniacal ( $\mathrm{N}$-amon.) e ortofosfato $\left(\mathrm{PO}_{4}\right)$, nas estações de coleta da ETE de Novo Horizonte, SP, no verão (fevereiro/2003).

\begin{tabular}{|c|c|c|c|c|c|c|c|}
\hline \multirow[b]{2}{*}{$\begin{array}{c}\text { Horário } \\
\text { de Coleta }\end{array}$} & \multirow[b]{2}{*}{ Estação } & \multicolumn{2}{|c|}{ Nutrientes Totais } & \multicolumn{4}{|c|}{ Nutrientes Dissolvidos } \\
\hline & & PT & NTK & $\mathrm{NO}_{2}$ & $\mathrm{NO}_{3}$ & N-amon. & $\mathrm{PO}_{4}$ \\
\hline \multirow{7}{*}{ t0 } & E3S & 7,0 & 42 & 0,019 & 2,5 & 25 & 2,55 \\
\hline & E3M & 8,6 & 39 & 0,022 & 2,4 & 23 & 2,51 \\
\hline & E3F & 8,7 & 37 & 0,007 & 2,0 & 28 & 2,32 \\
\hline & E4S & 7,9 & 31 & 0,017 & 2,2 & 22 & 3,03 \\
\hline & E4M & 6,0 & 31 & 0,011 & 2,2 & 25 & 3,45 \\
\hline & $\mathrm{E} 4 \mathrm{~F}$ & 7,0 & 38 & 0,007 & 2,2 & 28 & 3,55 \\
\hline & E5 & 6,1 & 31 & 0,008 & 2,2 & 25 & 2,99 \\
\hline \multirow[t]{6}{*}{$\mathrm{t} 1$} & E3S & 16,6 & 39 & 0,020 & 3,0 & 26 & 3,16 \\
\hline & E3M & 16,9 & 40 & 0,016 & 3,0 & 27 & 3,13 \\
\hline & E3F & 16,8 & 43 & 0,009 & 2,6 & 19 & 3,20 \\
\hline & E4S & 14,5 & 24 & 0,022 & 2,8 & 21 & 2,93 \\
\hline & E4M & 15,2 & 25 & 0,013 & 3,0 & 17 & 3,32 \\
\hline & E4F & 14,4 & 31 & 0,013 & 2,5 & 26 & 3,33 \\
\hline \multirow[t]{6}{*}{$\mathrm{t} 2$} & E3S & 19,1 & 42 & 0,011 & 3,3 & 30 & 3,57 \\
\hline & E3M & 16,6 & 42 & 0,014 & 3,1 & 29 & 3,96 \\
\hline & E3F & 17,3 & 40 & 0,010 & 2,8 & 28 & 3,87 \\
\hline & E4S & 14,8 & 24 & 0,040 & 3,0 & 19 & 3,81 \\
\hline & E4M & 14,5 & 26 & 0,033 & 2,9 & 21 & 3,73 \\
\hline & $\mathrm{E} 4 \mathrm{~F}$ & 16,1 & 30 & 0,015 & 2,6 & 25 & 3,95 \\
\hline \multirow[t]{6}{*}{ t3 } & E3S & 26,1 & 54 & 0,013 & 4,4 & 36 & 3,95 \\
\hline & E3M & 17,1 & 35 & 0,010 & 2,9 & 26 & 3,94 \\
\hline & E3F & 17,6 & 35 & 0,009 & 2,5 & 27 & 3,79 \\
\hline & E4S & 16,1 & 31 & 0,011 & 2,4 & 25 & 3,27 \\
\hline & E4M & 15,2 & 29 & 0,006 & 2,1 & 25 & 3,93 \\
\hline & $\mathrm{E} 4 \mathrm{~F}$ & 15,5 & 30 & 0,007 & 2,0 & 26 & 3,81 \\
\hline \multirow[t]{7}{*}{ t4 } & E3S & 18,4 & 44 & 0,007 & 2,6 & 28 & 3,67 \\
\hline & E3M & 17,2 & 37 & 0,010 & 2,6 & 26 & 3,49 \\
\hline & E3F & 16,4 & 38 & 0,005 & 1,6 & 28 & 3,21 \\
\hline & E4S & 14,6 & 26 & 0,006 & 1,8 & 20 & 3,69 \\
\hline & E4M & 14,9 & 31 & 0,009 & 2,2 & 22 & 3,82 \\
\hline & E4F & 15,8 & 32 & 0,008 & 2,0 & 26 & 3,82 \\
\hline & E5 & 15,1 & 31 & 0,048 & 2,8 & 24 & 3,94 \\
\hline
\end{tabular}




\subsection{Variáveis Biológicas}

\subsubsection{Comunidade Fitoplanctônica}

\subsubsection{Riqueza}

Foram encontrados, ao longo dos períodos de estudo, 32 gêneros fitoplanctônicos na lagoa facultativa 1 e 33 na facultativa 2, sendo que 21 deles foram comuns às duas lagoas. A maioria dos organismos pertencem à Chlorophyceae (40,6\% na primeira lagoa facultativa 1 e 45,5\% na segunda), seguida por Cyanophyceae (37,5\% e 36,4\%, respectivamente). A menor quantidade de gêneros encontrados foi de Euglenophyceae (12,5\% em E3 e 9,1\% em E4) e de Bacillariophyceae (9,4\% e 9,1\%, respectivamente). Os gêneros presentes nas lagoas e no efluente final são apresentados a seguir:

Lagoa Facultativa 1 CHLOROPHYCEAE

Chlamydomonas gracilis

Chlorella vulgaris

Chlorella sp

Chlorolobion sp

Closteriopsis acicularis

Crucigeniella rectangularis

Dictyosphaerium sp

Golenkinia radiata

Micractinium pusillum

Scenedesmus acuminatus

Spondylomorum quaternarium

Tetraedron minimum
Lagoa Facultativa 2

CHLOROPHYCEAE

Chlamydomonas gracilis

Chlorella vulgaris

Chlorella sp

Chlorolobion sp

Closteriopsis acicularis

Crucigeniella rectangularis

Dictyosphaerium sp

Golenkinia radiata

Micractinium pusillum

Pyrobotrys sp

Scenedesmus acuminatus

Spondylomorum quaternarium

Tetraedron minimum

Espécie considerada rara não identificada 1 Espécie considerada rara não identificada 1 Espécie considerada rara não identificada 2 
CYANOPHYCEAE

Aphanocapsa sp

Aphanothece sp

Oscillatoria limnetica

Oscillatoria minesotensis

Rhaphidiopsis curvata

Spirulina menghiniana

Synechocystis sp1

Synechocystis sp2

Chroococcus minutus

Chroococcus sp
CYANOPHYCEAE

Aphanocapsa sp

Aphanothece sp

Oscillatoria limnetica

Oscillatoria minesotensis

Rhaphidiopsis curvata

Spirulina menghiniana

Synechocystis sp1

Synechocystis sp2

Chroococcus minutus

Chroococcus sp

Espécie considerada rara não identificada 1 Espécie considerada rara não identificada 1

Espécie considerada rara não identificada 2 Espécie considerada rara não identificada 2

EUGLENOPHYCEAE

Euglena acus

Lepocinclis ovum

Lepocinclis sp

Trachelomonas sp

BACILLARIOPHYCEAE

Nitzschia sp

\section{EUGLENOPHYCEAE}

Lepocinclis ovum

Lepocinclis sp

Trachelomonas sp

\section{BACILLARIOPHYCEAE}

\section{Nitzschia sp}

Espécie considerada rara não identificada 1 Espécie considerada rara não identificada 1 Espécie considerada rara não identificada 2 Espécie considerada rara não identificada 2

\subsubsection{Densidade Fitoplanctônica}

Ocorreram variações significativas na densidade fitoplanctônica entre todos os períodos de coleta, especialmente entre o outono e as demais épocas; neste período, foram observadas as menores densidades.

Os coeficientes de variação são apresentados no Apêndice A. 
Chlorophyceae foi a classe que apresentou maiores densidades fitoplanctônicas em todos os períodos de estudo. Apenas no outono Cyanophyceae, por quatro vezes, mostrou densidade superior, sendo a maior delas registrada no fundo da segunda lagoa, em t3 (6.587,7 org/mL). Para Chlorophyceae, os valores mais altos desta variável no outono foram encontrados na superfície da mesma lagoa, em t4 (54.662,9 org/mL). A maior densidade de Euglenophyceae foi obtida a 1,5 m de profundidade da última lagoa, também em t4 (4.839,1 org/mL) e a de Bacillariophyceae, na mesma profundidade da outra lagoa, em t3 (903,2 org/mL) (Figura 42).
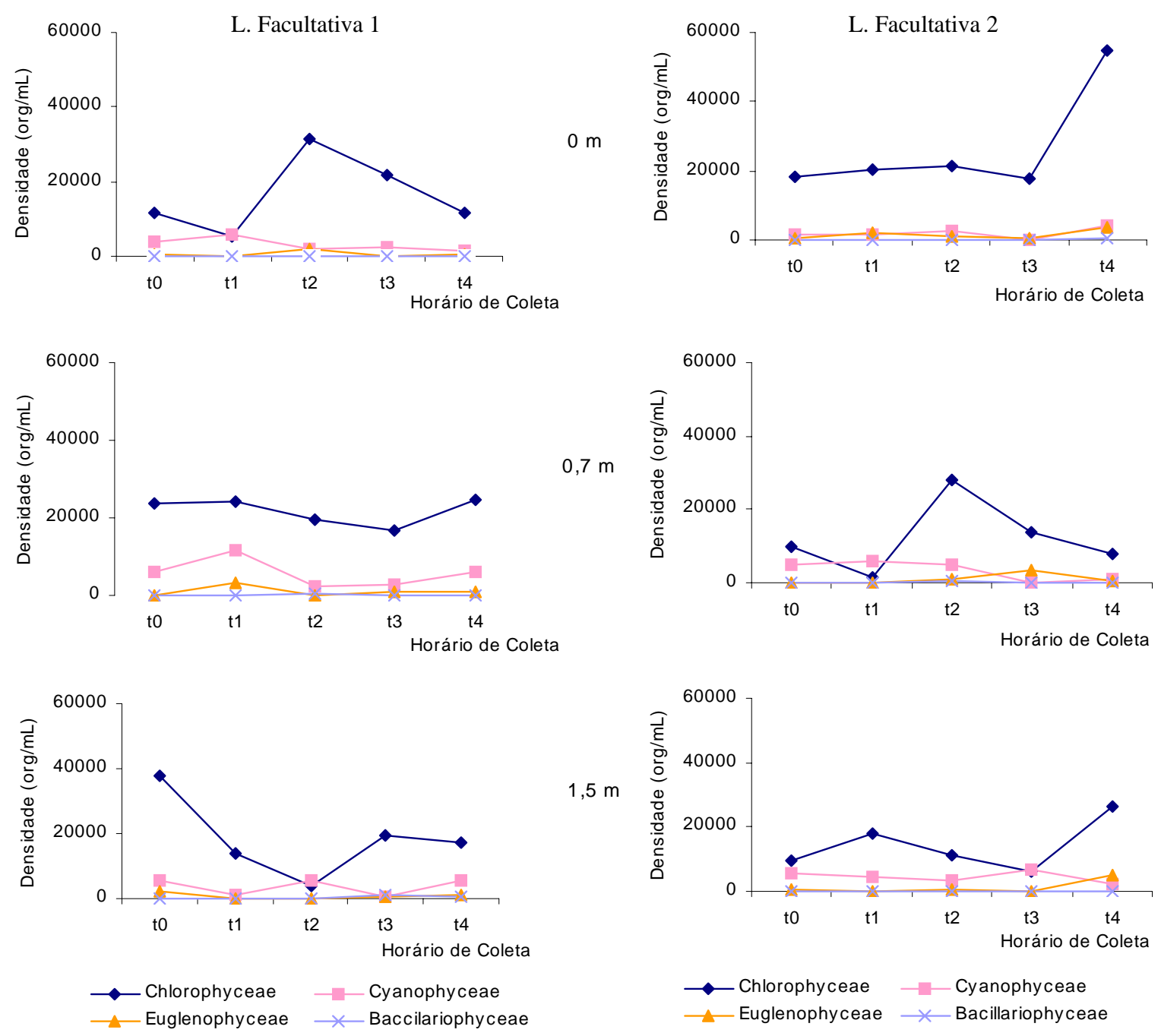

Figura 42: Densidade das classes fitoplanctônicas encontradas nas lagoas facultativa 1 e facultativa 2 da ETE de Novo Horizonte, SP, no outono (maio/2002). 
No inverno foram obtidas densidades muito maiores que as encontradas nos demais períodos de estudo, para todas as classes. Para Chlorophyceae, o valor máximo foi registrado à $0,7 \mathrm{~m}$ de profundidade da lagoa facultativa 1 , em t3 (875.834,7 org/ML); em média, as densidades dessa classe oscilaram entre 600.000 e 700.000 org/mL. Cyanophyceae apresentou sua maior densidade na mesma lagoa, profundidade e horário da classe anterior (434.846,4 org/mL) e Euglenophyceae, na superfície da mesma lagoa, em t1 (234.620,5 org/mL) (Figura 43).

L. Facultativa 1
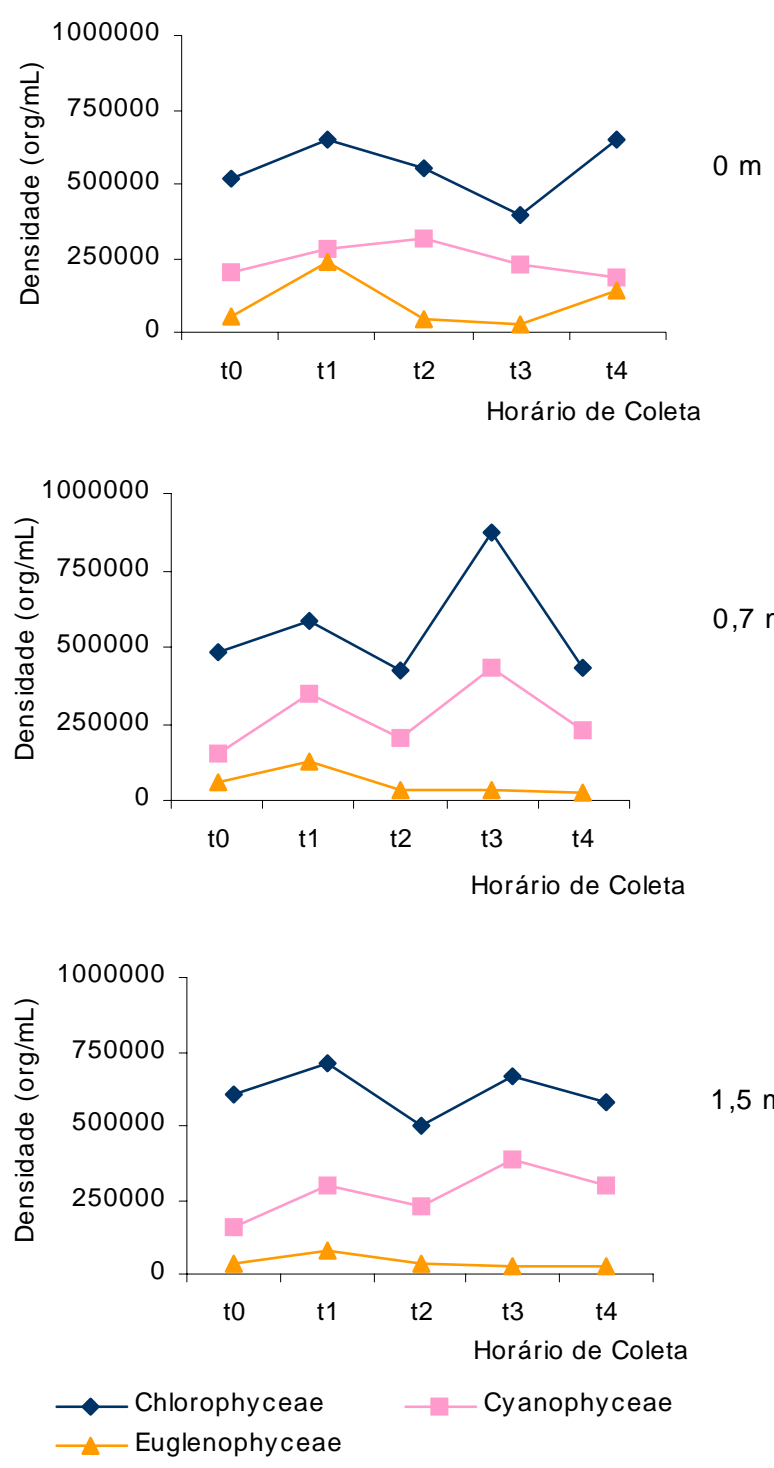

L. Facultativa 2
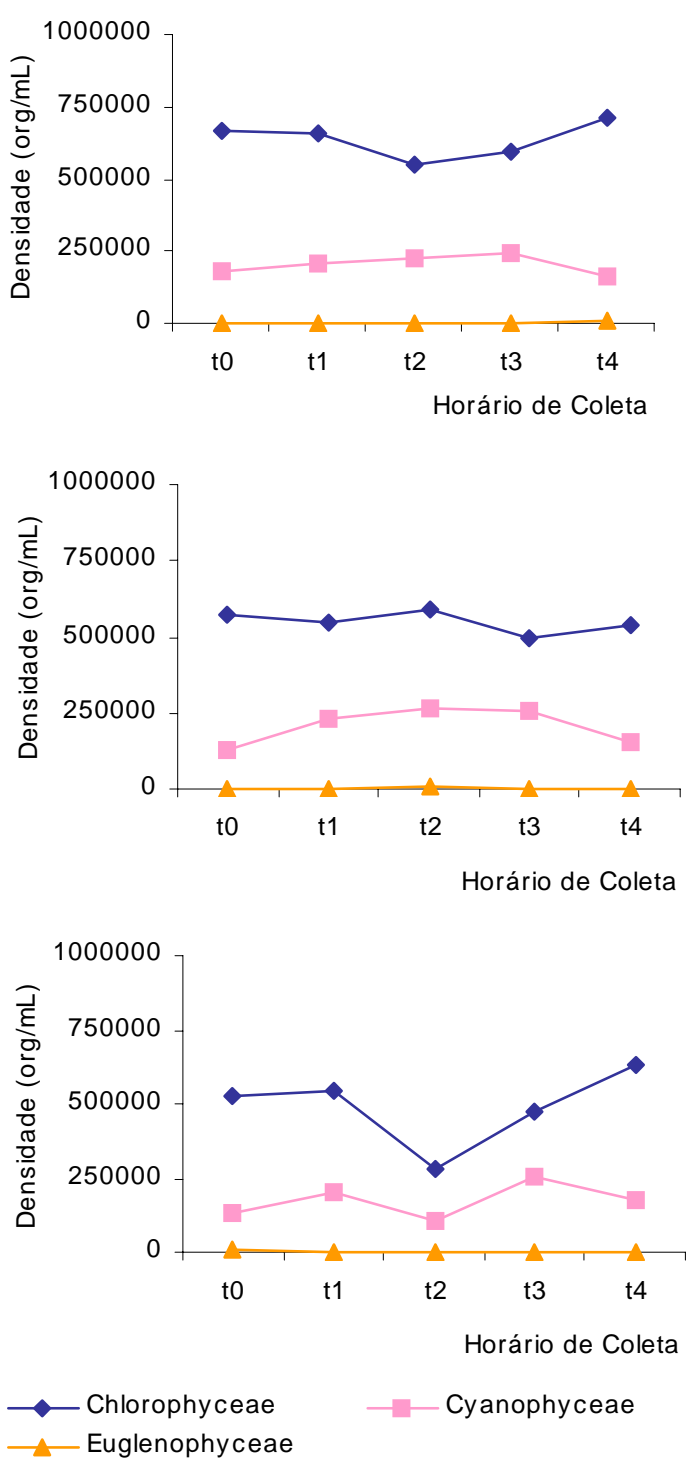

Figura 43: Densidade das classes fitoplanctônicas encontradas nas lagoas facultativa 1 e facultativa 2 da ETE de Novo Horizonte, SP, no inverno (agosto/2002).

Na primavera, as maiores densidades encontradas foram: 571.196,5 org/mL para Chlorophyceae, na superfície da lagoa facultativa 1, em t0; 201.454,3 org/mL, para Cyanophyceae, a 0,7 m da mesma lagoa, em t3; e 11.055,4 org/mL, para 
Euglenophyceae, na mesma lagoa e profundidade da anterior, em t0. A 0,7 m da outra lagoa, em t0, não foram registrados organismos, porque existiam fungos na amostra e não foi possível contá-la (Figura 44).
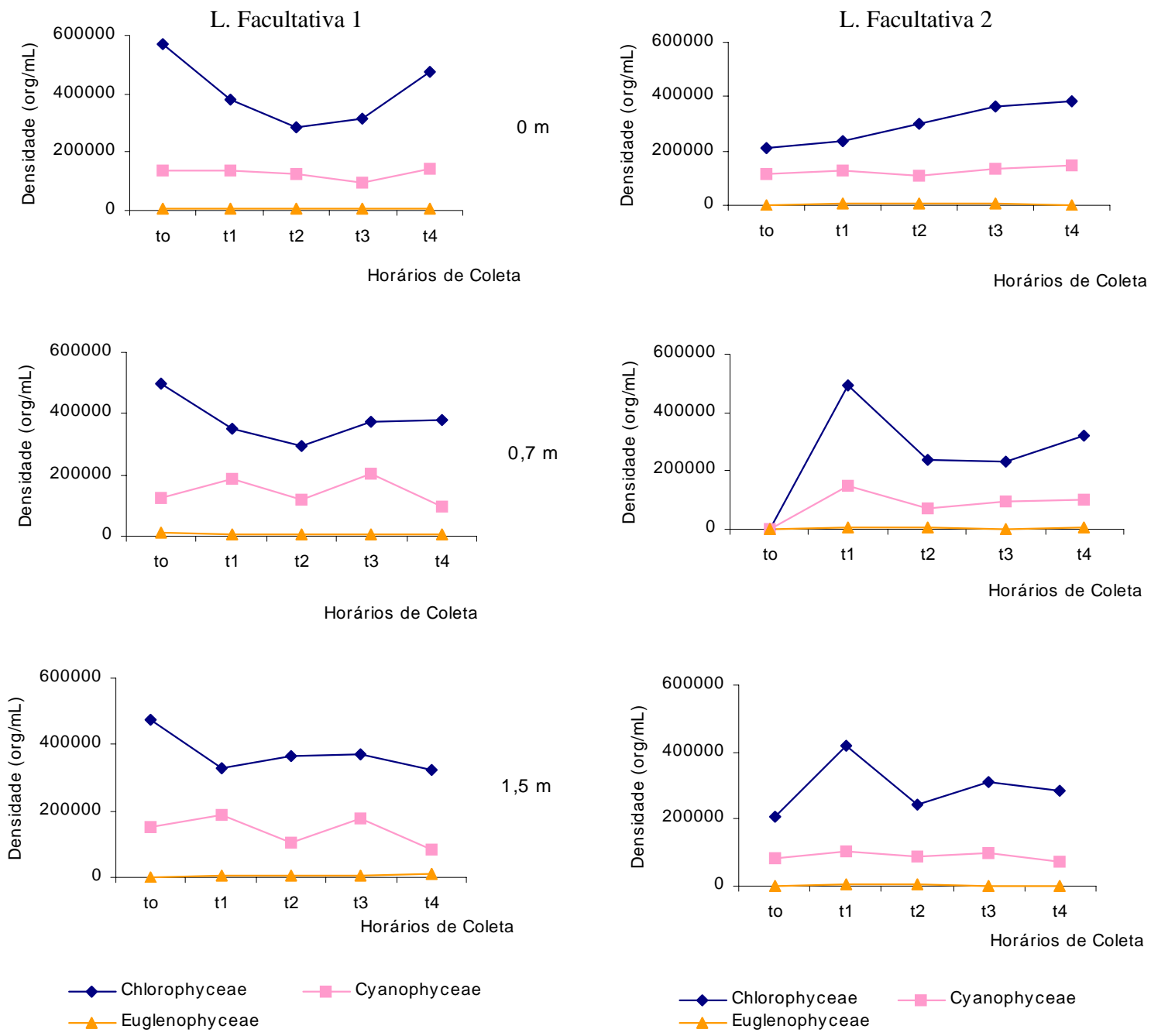

Figura 44: Densidade das classes fitoplanctônicas encontradas nas lagoas facultativa 1 e facultativa 2 da ETE de Novo Horizonte, SP, na primavera (novembro/2002).

No verão, Chlorophyceae mostrou maior densidade no fundo de E3, em t4 (421.334,2 org/mL); no entanto, a maioria dos resultados estiveram abaixo de 200.000 org/mL. O valor máximo para Cyanophyceae foi registrado na superfície da primeira lagoa facultativa, em t0 (83.529,8 org/mL); na mesma lagoa, profundidade e horário também foi encontrada a maior densidade para Euglenophyceae (67.151,4 org/mL). Para Bacillariophyceae, o único valor de densidade registrado ocorreu em t2, na superfície de E4 (Figura 45). 
L. Facultativa 1
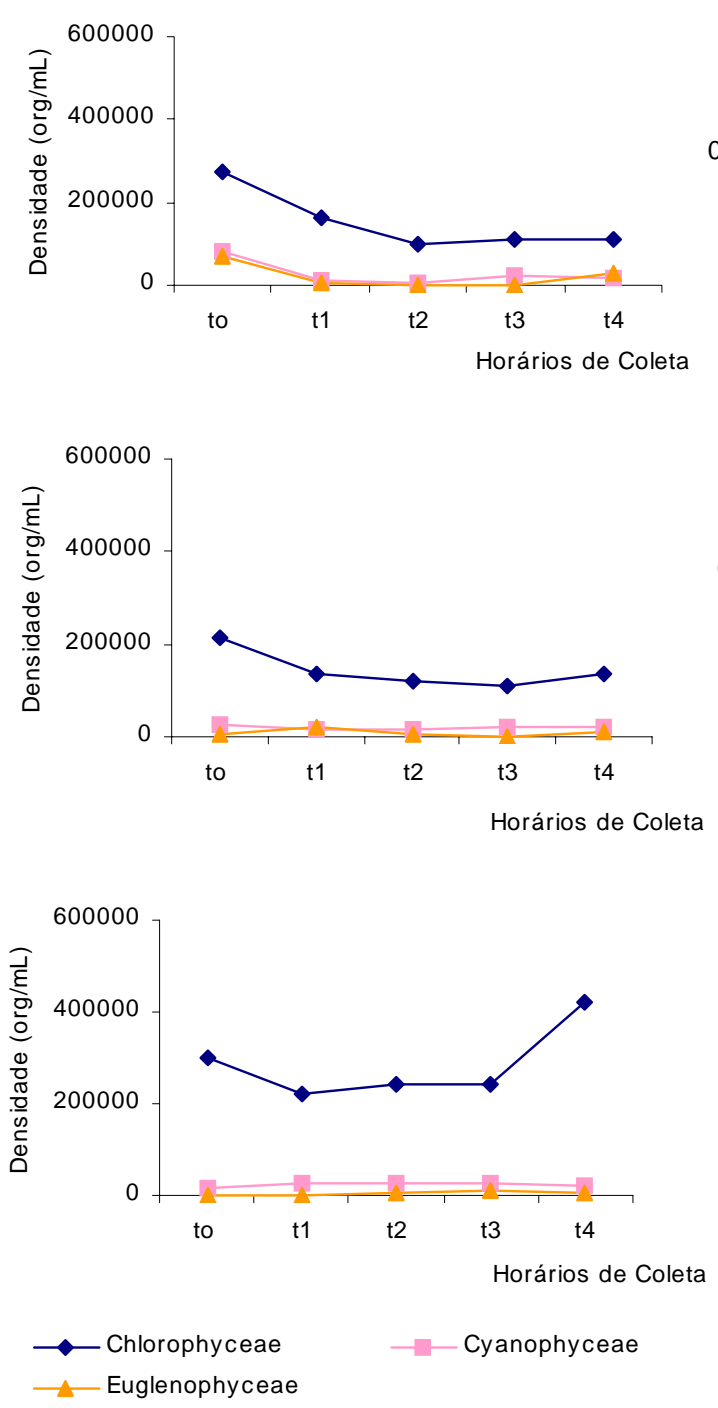
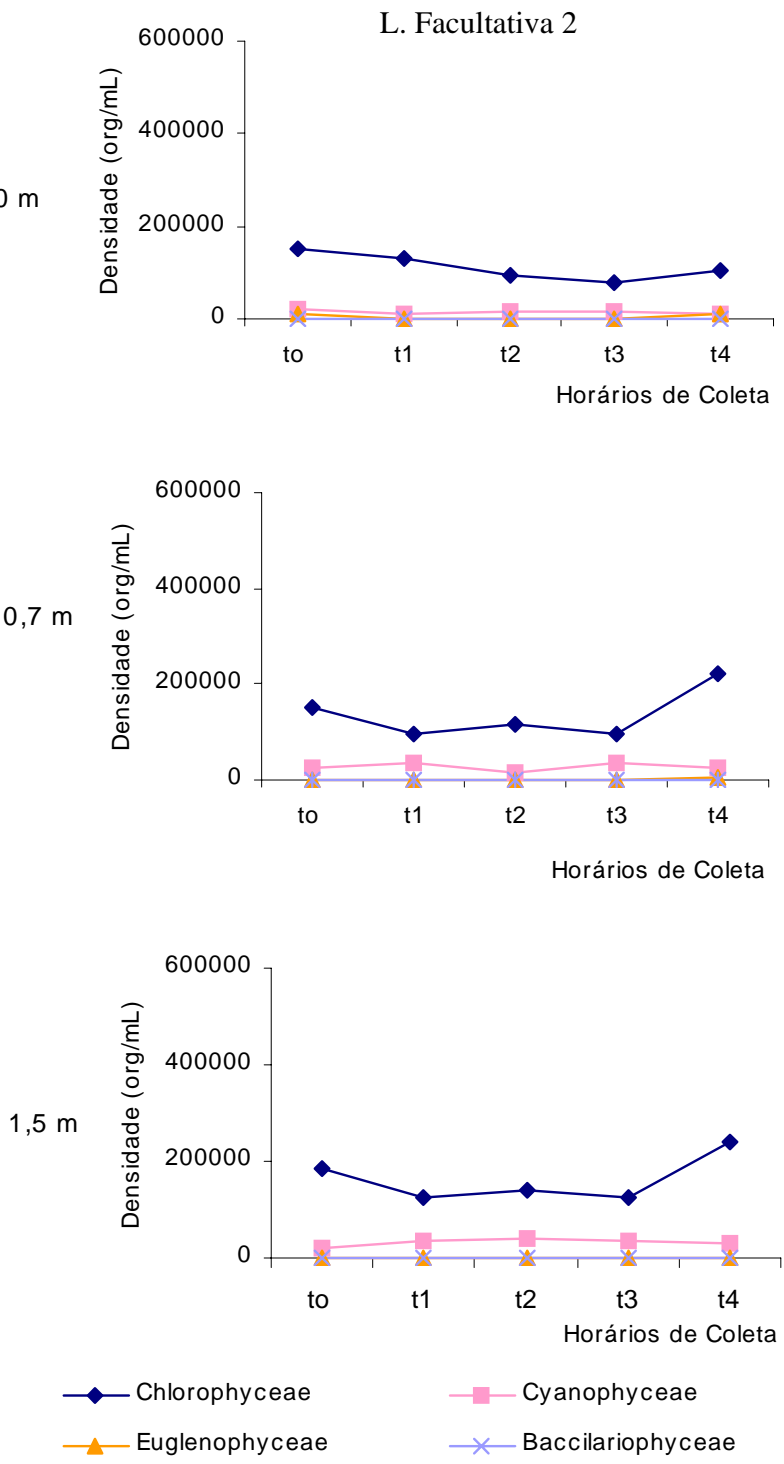

Figura 45: Densidade das classes fitoplanctônicas encontradas nas lagoas facultativa 1 e facultativa 2 da ETE de Novo Horizonte, SP, no verão (fevereiro/2003).

O efluente final mostrou comportamento bastante semelhante ao das lagoas, com grandes variações de densidade entre as épocas de estudo. Os maiores valores foram encontrados no inverno; para Chlorophyceae, o máximo foi registrado em t0 (568.739,8 org/mL) e para Cyanophyceae, em t4 (269.015,1 org/mL). No entanto, Euglenophyceae, apresentou maior valor no efluente final em t4, no verão (14.740,6 org/mL) (Figura 46). 

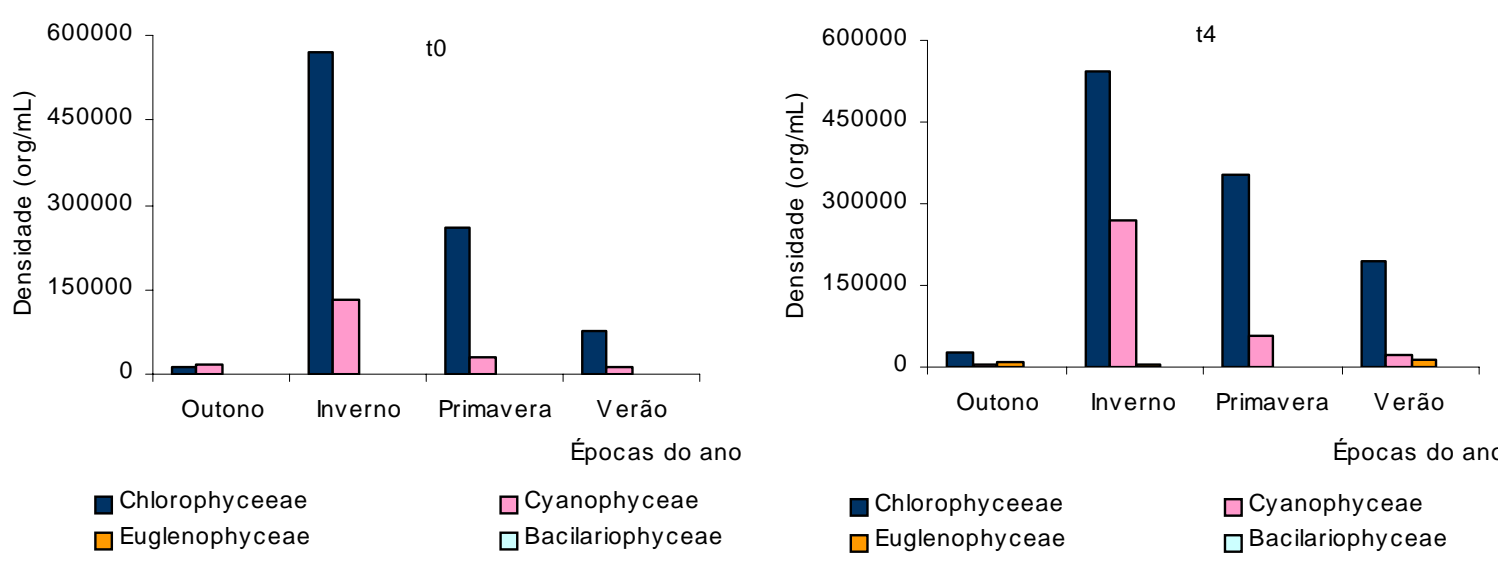

Figura 46: Densidade das classes fitoplanctônicas encontradas no efluente final da ETE de Novo Horizonte, nos períodos de estudo.

\subsubsection{Percentagem de Contribuição das Classes}

Os valores de percentagem de contribuição das classes foram apresentados como médias do período, porque as variações entre as profundidades e os horários foram semelhantes; no entanto, os desvios padrão também são mostrados.

Como são observados nos gráficos de densidade, Chlorophyceae foi a classe que mais contribuiu para a densidade fitoplanctônica em todas as épocas de estudo. A maior contribuição da classe foi registrada no verão, com $84,7 \%$ na lagoa facultativa 1 e $83,7 \%$ na 2. Cyanophyceae contribuiu com mais de $20 \%$, com exceção do verão. Na lagoa facultativa 1 , as porcentagens de contribuição de Cyanophyceae e Euglenophyceae apresentaram variação significativa entre os períodos de estudo, principalmente entre o verão e as demais épocas (Apêndice A). Na outra lagoa, Euglenophyceae mostrou grande variação entre o outono e as outras estações do ano. Para Bacillariophyceae, só foram registradas contribuições no outono , abaixo de 1\% (Tabela 8). 
Tabela 8: Porcentagem de contribuição média das classes fitoplanctônicas na ETE de Novo Horizonte, SP, por período de estudo.

\begin{tabular}{|c|c|c|c|c|c|}
\hline \multirow[t]{2}{*}{ Período } & \multirow[t]{2}{*}{ Classes } & \multicolumn{2}{|c|}{ Lagoa Facultativa 1} & \multicolumn{2}{|c|}{ Lagoa Facultativa 2} \\
\hline & & $\begin{array}{l}\text { \% de Contr. } \\
\text { Média }\end{array}$ & $\begin{array}{l}\text { Desvio } \\
\text { Padrão }\end{array}$ & $\begin{array}{l}\text { \% de Contr. } \\
\text { Média }\end{array}$ & $\begin{array}{l}\text { Desvio } \\
\text { Padrão }\end{array}$ \\
\hline \multirow[t]{4}{*}{ Outono } & Chlorophyceae & 77,1 & 16,7 & 75,1 & 15,5 \\
\hline & Cyanophyceae & 20,3 & 16,7 & 20,9 & 17,6 \\
\hline & Euglenophyceae & 2,7 & 2,5 & 4,9 & 5,8 \\
\hline & Bacillariophyceae & 0,6 & 0,9 & 0,2 & 0,4 \\
\hline \multirow[t]{3}{*}{ Inverno } & Chlorophyceae & 66,5 & 7,7 & 79,0 & 5,7 \\
\hline & Cyanophyceae & 25,9 & 6,4 & 20,8 & 5,8 \\
\hline & Euglenophyceae & 7,8 & 6,1 & 0,2 & 0,3 \\
\hline \multirow[t]{3}{*}{ Primavera } & Chlorophyceae & 72,7 & 6,0 & 73,4 & 3,7 \\
\hline & Cyanophyceae & 26,2 & 6,1 & 25,9 & 3,8 \\
\hline & Euglenophyceae & 1,1 & 0,5 & 0,8 & 0,5 \\
\hline \multirow[t]{3}{*}{ Verão } & Chlorophyсеае & 84,7 & 6,6 & 83,7 & 6,2 \\
\hline & Cyanophyceae & 10,8 & 4,2 & 15,0 & 6,2 \\
\hline & Euglenophyceae & 4,5 & 4,7 & 1,2 & 1,4 \\
\hline
\end{tabular}

\subsubsection{Abundância Relativa}

Os valores de abundância relativa também foram apresentados como médias obtidas no período, acompanhados dos desvios padrão, pelos mesmos motivos citados.

Durante o outono, Chlorella vulgaris (Chlorophyceae) foi classificada como abundante nas duas lagoas (mais de 30\% de abundância relativa). Os organismos comuns para ambas lagoas foram: Closteriopsis acicularis (Chlorophyceae) (26,2\% e 16,2\%) e Dictyosphaerium sp (Chlorophyceae) (13,6\% e 21,6\%); enquanto que Aphanocapsa sp (Cyanophyceae) foi comum apenas para a primeira lagoa estudada (10,6\%). Neste período não existiram organismos considerados como dominantes (Tabela 9). 
Tabela 9: Abundância relativa média dos organismos fitoplanctônicos encontrados nas lagoas facultativa 1 e facultativa 2 da ETE de Novo Horizonte, SP, no outono (maio/2002).

\begin{tabular}{|c|c|c|c|c|c|c|}
\hline \multirow[t]{2}{*}{ Organismos } & \multicolumn{3}{|c|}{ L. Facultativa 1} & \multicolumn{3}{|c|}{ L. Facultativa 2} \\
\hline & $\begin{array}{c}\text { Abund. } \\
\text { Relativa } \\
\text { (\%) }\end{array}$ & $\begin{array}{l}\text { Desvio } \\
\text { Padrão }\end{array}$ & Classificação & $\begin{array}{c}\text { Abund. } \\
\text { Relativa } \\
\text { (\%) }\end{array}$ & $\begin{array}{l}\text { Desvio } \\
\text { Padrão }\end{array}$ & Classificação \\
\hline Chlorella vulgaris & 30,9 & 5,6 & Abundante & 34,3 & 12,8 & Abundante \\
\hline Chlorella sp & 1,4 & 1,1 & Ocasional & 0,7 & 0,8 & Rara \\
\hline Closteriopsis acicularis & 26,2 & 10,7 & Comum & 16,2 & 9,2 & Comum \\
\hline $\begin{array}{l}\text { Crucigeniella } \\
\text { rectangularis }\end{array}$ & 2,5 & 2,8 & Ocasional & 1,0 & 1,0 & Ocasional \\
\hline Dictyosphaerium sp & 13,6 & 6,7 & Comum & 21,6 & 9,1 & Comum \\
\hline Golenkinia radiata & - & 0 & - & 1,2 & 0,2 & Ocasional \\
\hline $\begin{array}{l}\text { Chlorophyceae } \quad \text { não } \\
\text { identificada } 1\end{array}$ & 0,0 & 0 & - & 0,7 & 1,2 & Rara \\
\hline Aphanotece sp & 9,3 & 6,1 & Ocasional & 9,6 & 9,4 & Ocasional \\
\hline Aphanocapsa sp & 10,6 & 12,8 & Comum & 7,7 & 14,4 & Ocasional \\
\hline Raphidiopsis sp & 1,1 & 1,1 & Ocasional & 0,3 & 0,5 & Rara \\
\hline $\begin{array}{l}\text { Cyanophyceae } \\
\text { identificada } 1\end{array}$ & 0,7 & 0 & Rara & 0,8 & 1,4 & Rara \\
\hline Lepocinclis sp & 1,7 & 1,4 & Ocasional & 2,7 & 1,5 & Ocasional \\
\hline Lepocinclis ovum & 0,0 & 0 & - & 1,7 & 0 & Ocasional \\
\hline Trachelomonas sp & 1,3 & 0,3 & Ocasional & 1,0 & 1,4 & Ocasional \\
\hline $\begin{array}{l}\text { Bacillariophyceae não } \\
\text { identificada } 2\end{array}$ & 0,5 & 0,7 & Rara & 0,2 & 0 & Rara \\
\hline
\end{tabular}

No inverno, Chlorella vulgaris (Chlorophyceae) foi dominante em ambas as lagoas, com 57,4\% de abundância relativa média no período em E3 e 65,9\% em E4; enquanto que os outros organismos foram ocasionais ou raros; com exceção de Synechocystis sp1 (Cyanophyceae), considerada comum, com 26,5\% de abundância relativa na primeira lagoa estudada e $23,7 \%$ na outra (Tabela 10 ). 
Tabela 10: Abundância relativa média dos organismos fitoplanctônicos encontrados nas lagoas facultativa 1 e facultativa 2 da ETE de Novo Horizonte, SP, no inverno (agosto/2002)..

\begin{tabular}{|c|c|c|c|c|c|c|}
\hline \multirow[t]{2}{*}{ Organismos } & \multicolumn{3}{|c|}{ L. Facultativa 1} & \multicolumn{3}{|c|}{ L. Facultativa 2} \\
\hline & $\begin{array}{c}\text { Abund. } \\
\text { Relativa } \\
\text { (\%) }\end{array}$ & $\begin{array}{l}\text { Desvio } \\
\text { Padrão }\end{array}$ & Classificação & $\begin{array}{c}\text { Abund. } \\
\text { Relativa } \\
\text { (\%) }\end{array}$ & $\begin{array}{l}\text { Desvio } \\
\text { Padrão }\end{array}$ & Classificação \\
\hline Chlorella vulgaris & 57,4 & 3,0 & Dominante & 65,9 & 2,5 & Dominante \\
\hline Chlorella sp & 2,2 & 0,6 & Ocasional & 3,3 & 0,9 & Ocasional \\
\hline Chlorolobion sp & 0,5 & 0,3 & Rara & 0,6 & 0,3 & Rara \\
\hline Closteriopsis acicularis & 0,8 & 0,3 & Rara & 1,3 & 0,4 & Ocasional \\
\hline $\begin{array}{l}\text { Crucigeniella } \\
\text { rectangularis }\end{array}$ & 2,0 & 0,5 & Ocasional & 2,1 & 0,8 & Ocasional \\
\hline Golenkinia radiata & 0,8 & 0,3 & Rara & 0,8 & 0,5 & Rara \\
\hline Aphanotece sp & 0,2 & 0,1 & Rara & - & 0 & - \\
\hline Aphanocapsa sp & 0,2 & 0,4 & Rara & 0,2 & 0,3 & Rara \\
\hline Oscillatoria sp 1 & 0,4 & 0,3 & Rara & 0,2 & 0,3 & Rara \\
\hline Oscillatoria sp 2 & 0,2 & 0,3 & Rara & 0,3 & 0,2 & Rara \\
\hline Spirulina meneghiniana & 1,1 & 0,3 & Ocasional & 1,1 & 0,4 & Ocasional \\
\hline Synechocystis sp 1 & 26,5 & 3,7 & Comum & 23,7 & 2,3 & Comum \\
\hline Synechocystis sp 2 & 0,4 & 0,3 & Rara & 0,2 & 0,2 & Rara \\
\hline Lepocinclis sp & 1,4 & 0,9 & Ocasional & 0,1 & 0,1 & Rara \\
\hline Lepocinclis ovum & 5,6 & 2,8 & Ocasional & 0,1 & 0,2 & Rara \\
\hline Euglena acus & 0,3 & 0,5 & Rara & - & 0 & - \\
\hline
\end{tabular}

Na primavera, novamente não ocorreram organismos dominantes; Chlorella vulgaris (Chlorophyceae) foi considerada abundante, com cerca de $47 \%$ de abundância relativa nas duas lagoas. A espécie Synechocystis sp1 (Cyanophyceae) apresentou-se como comum, com 28,9\% e 24,5\%, para as duas lagoas, respectivamente. Chlorella sp (Chlorophyceae), também foi comum, mas somente na lagoa facultativa 2 (13,3\%); os demais organismos foram considerados ocasionais ou raros (Tabela 11). 
Tabela 11: Abundância relativa média dos organismos fitoplanctônicos encontrados nas lagoas facultativa 1 e facultativa 2 da ETE de Novo Horizonte, SP, na primavera (novembro/2002).

\begin{tabular}{|c|c|c|c|c|c|c|}
\hline \multirow[t]{2}{*}{ Organismos } & \multicolumn{3}{|c|}{ L. Facultativa 1} & \multicolumn{3}{|c|}{ L. Facultativa 2} \\
\hline & $\begin{array}{c}\text { Abund. } \\
\text { Relativa } \\
\text { (\%) }\end{array}$ & $\begin{array}{l}\text { Desvio } \\
\text { Padrão }\end{array}$ & Classificação & $\begin{array}{c}\text { Abund. } \\
\text { Relativa } \\
\text { (\%) }\end{array}$ & $\begin{array}{l}\text { Desvio } \\
\text { Padrão }\end{array}$ & Classificação \\
\hline Chlamydomonas sp & 0,2 & 6,6 & Rara & 0,0 & 0,2 & - \\
\hline Chlorella vulgaris & 47,8 & 10,9 & Abundante & 47,0 & 2,9 & Abundante \\
\hline Chlorella sp & 6,3 & 1,9 & Ocasional & 13,3 & 2,2 & Comum \\
\hline Chlorolobion sp & 1,3 & 1,3 & Ocasional & 0,0 & 0,5 & - \\
\hline Closteriopsis acicularis & 3,7 & 1,1 & Ocasional & 6,6 & 1,3 & Ocasional \\
\hline $\begin{array}{l}\text { Crucigeniella } \\
\text { rectangularis }\end{array}$ & 3,6 & 1,2 & Ocasional & 2,8 & 0,8 & Ocasional \\
\hline Golenkinia radiata & 5,6 & 1,9 & Ocasional & 3,4 & 2,1 & Ocasional \\
\hline Micractinium sp & 0,2 & 0,2 & Rara & 0,3 & 0,4 & Rara \\
\hline Aphanocapsa sp & 0,3 & 0,1 & Rara & - & 0,1 & - \\
\hline Raphidiopsis sp & 0,0 & 0,2 & - & 0,7 & 0,3 & Rara \\
\hline Oscillatoria sp 2 & 1,4 & 0,5 & Ocasional & 0,8 & 0,4 & Rara \\
\hline Synechocystis sp 1 & 28,9 & 5,0 & Comum & 24,5 & 3,8 & Comum \\
\hline Lepocinclis sp & 0,6 & 0,4 & Rara & 0,6 & 0,5 & Rara \\
\hline lepocinclis ovum & 0,2 & 0,2 & Rara & - & - & - \\
\hline
\end{tabular}

Na coleta de verão, Chlorella vulgaris (Chlorophyceae) também foi registrada como abundante, com 36,2\% de abundância relativa em E3 e 45,2\% em E4. Golenkinia radiata (Chlorophyceae) foi considerada comum nas duas lagoas, com 13,7\% e 18,8\%, para cada lagoa. Chlorella sp (Chlorophyceae) e Crucigeniella rectangularis (Chlorophyceae) também foram comuns, mas somente na lagoa facultativa 1, com abundâncias de 15,3\% e 13,3\%, respectivamente. Os outros organismos foram considerados ocasionais ou raros (Tabela 12). 
Tabela 12: Abundância relativa média dos organismos fitoplanctônicos encontrados nas lagoas facultativa 1 e facultativa 2 da ETE de Novo Horizonte, SP, no verão (fevereiro/2003).

\begin{tabular}{|c|c|c|c|c|c|c|}
\hline \multirow[t]{2}{*}{ Organismos } & \multicolumn{3}{|c|}{ L. Facultativa 1} & \multicolumn{3}{|c|}{ L. Facultativa 2} \\
\hline & $\begin{array}{c}\text { Abund. } \\
\text { Relativa } \\
\text { (\%) }\end{array}$ & $\begin{array}{l}\text { Desvio } \\
\text { Padrão }\end{array}$ & Classificação & $\begin{array}{c}\text { Abund. } \\
\text { Relativa } \\
\text { (\%) }\end{array}$ & $\begin{array}{l}\text { Desvio } \\
\text { Padrão }\end{array}$ & Classificação \\
\hline Chlamydomonas sp & 0,2 & 0,2 & Rara & 0,7 & 1,0 & Rara \\
\hline Chlorella vulgaris & 36,2 & 14,2 & Abundante & 45,2 & 10,6 & Abundante \\
\hline Chlorella sp & 15,3 & 11,2 & Comum & 6,1 & 8,1 & Ocasional \\
\hline Chlorolobion sp & 2,0 & 0,9 & Ocasional & - & 0,7 & - \\
\hline Closteriopsis acicularis & 4,4 & 1,8 & Ocasional & 6,0 & 1,8 & Ocasional \\
\hline Crucigeniella & & & Comum & & & Ocasional \\
\hline rectangularis & 13,3 & 3,9 & & 9,7 & 4,9 & \\
\hline Dictyosphaerium sp & 0,1 & 0,0 & Rara & 0,0 & 0,1 & - \\
\hline Golenkinia radiata & 13,7 & 3,2 & Comum & 18,8 & 2,2 & Comum \\
\hline Micractinium sp & 0,0 & 0,2 & - & 0,2 & 0,7 & Rara \\
\hline Scenedesmus sp & 0,2 & 0,1 & Rara & 0,1 & 0,1 & Rara \\
\hline Spondylomorum sp & 0,2 & 0,1 & Rara & 0,1 & 0,1 & Rara \\
\hline Aphanocapsa sp & 0,2 & 0,3 & Rara & 0,1 & 0,4 & Rara \\
\hline Raphidiopsis sp & 0,9 & 0,9 & Rara & 1,4 & 0,8 & Ocasional \\
\hline Oscillatoria sp 2 & 0,9 & 0,8 & Rara & 1,6 & 0,6 & Ocasional \\
\hline Spirulna meneghiniana & 0,2 & 0,2 & Rara & - & 0,1 & - \\
\hline Synechocystis sp 1 & 6,2 & 4,2 & Ocasional & 6,7 & 3,9 & Ocasional \\
\hline $\begin{array}{l}\text { Cyanophyceae não } \\
\text { identificada } 4\end{array}$ & 0,1 & 0,2 & Rara & 0,4 & 0 & Rara \\
\hline Lepocinclis sp & 4,4 & 2,1 & Ocasional & 0,4 & 0,1 & Rara \\
\hline Lepocincli ovum & 1,5 & 3,2 & Ocasional & 2,7 & 1,3 & Ocasional \\
\hline
\end{tabular}

\subsubsection{5 Índices de Diversidade de Espécies, Dominância, Equidade e Riqueza}

Os índices de diversidade obtidos mostraram-se baixos em todos os períodos, sempre menores que 1 . Os maiores valores foram registrados no verão, 0,834 e 0,838 para as lagoas facultativa 1 e 2, respectivamente; no inverno, foram encontrados índices bem próximos a esses, em torno de 0,80. Os valores mais baixos foram obtidos no inverno, 0,566 em E3 e 0,461 em E4 (Figura 47). Não foram verificadas variações significativas entre os períodos e as lagoas estudadas (Apêndice A). 


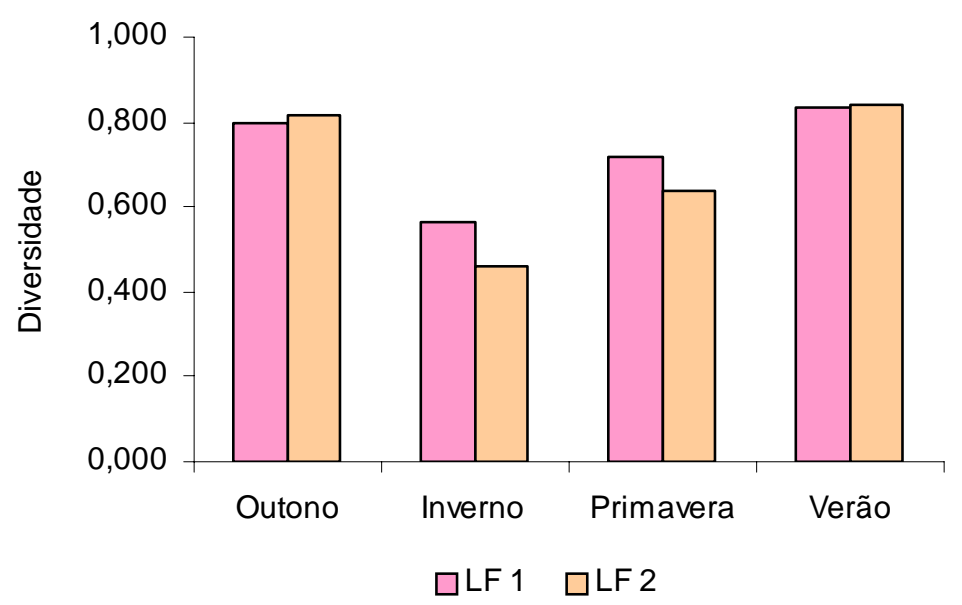

Figura 47: Índices de diversidade encontrados nos períodos de estudo, nas lagoas facultativa 1 e facultativa 2 da ETE de Novo Horizonte, SP.

Os índices de dominância estiveram mais altos no inverno, 0,404 na lagoa facultativa 1 e 0,492 na 2, com variação significativa entre esse período e o verão. $O$ menor valor na primeira lagoa estudada foi encontrado no outono $(0,204)$, enquanto que na outra lagoa foi obtido no verão $(0,191)$ (Figura 48).

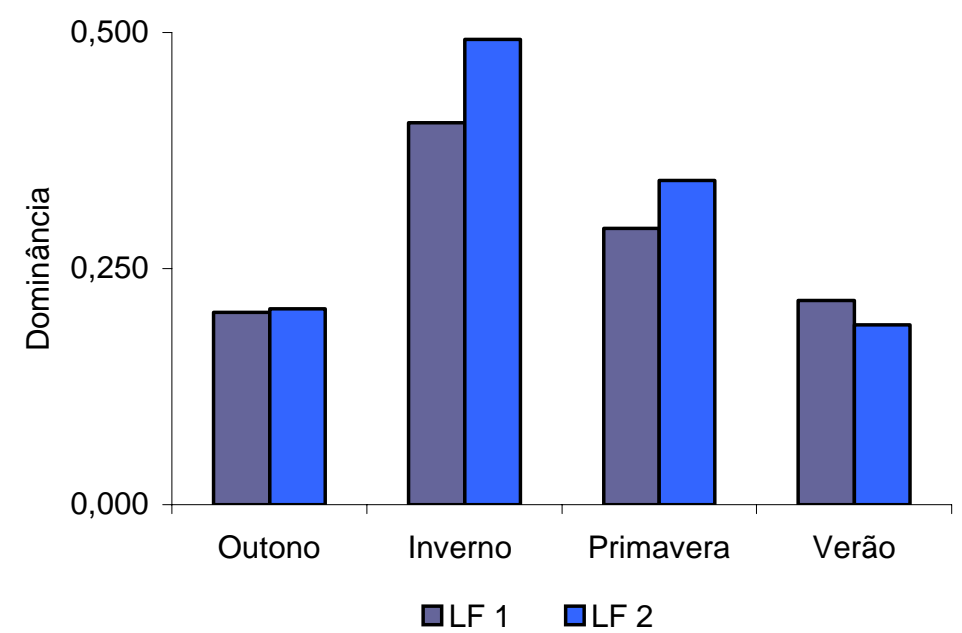

Figura 48: Índices de dominância obtidos nos períodos amostrados, nas lagoas facultativa 1 e facultativa 2 da ETE de Novo Horizonte, SP.

A equidade apresentou-se maior no outono, com valores de 0,680 e 0,662 para E3 e E4, respectivamente; enquanto que os resultados mais baixos foram registrados no inverno, 0,470 na primeira lagoa estudada e 0,392 na outra, no entanto não foram observadas variações significativas (Figura 49). 


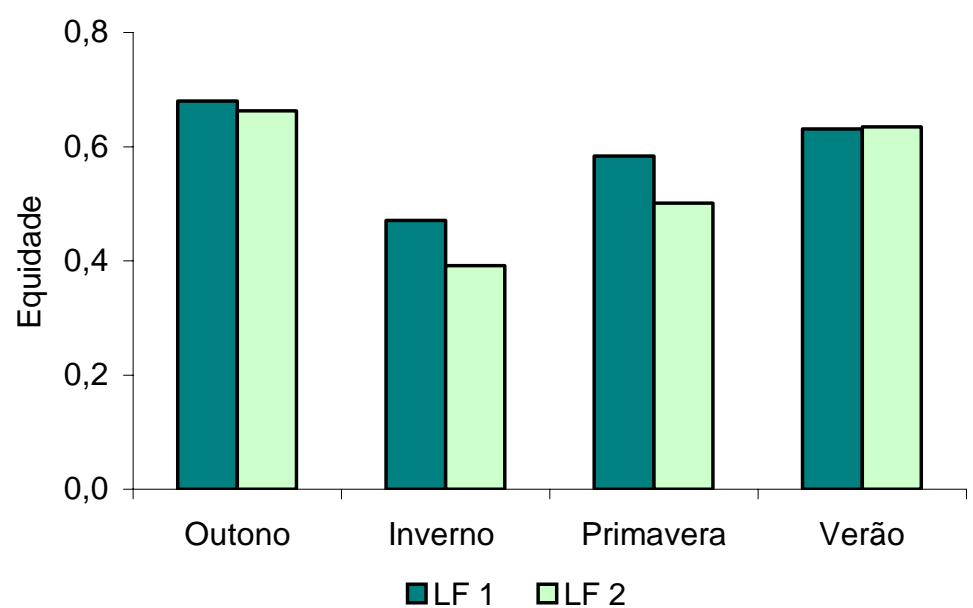

Figura 49: Valores de equidade encontrados nos períodos estudados nas lagoas facultativa 1 e facultativa 2 da ETE de Novo Horizonte, SP.

Os índices de riqueza estiveram mais altos no verão (6,53 na primeira lagoa facultativa e 6,34 na segunda); já os mais baixos, foram registrados no inverno (4,43 e 4,23 para as lagoas, respectivamente), porém, essas variações não foram significativas (Figura 50).

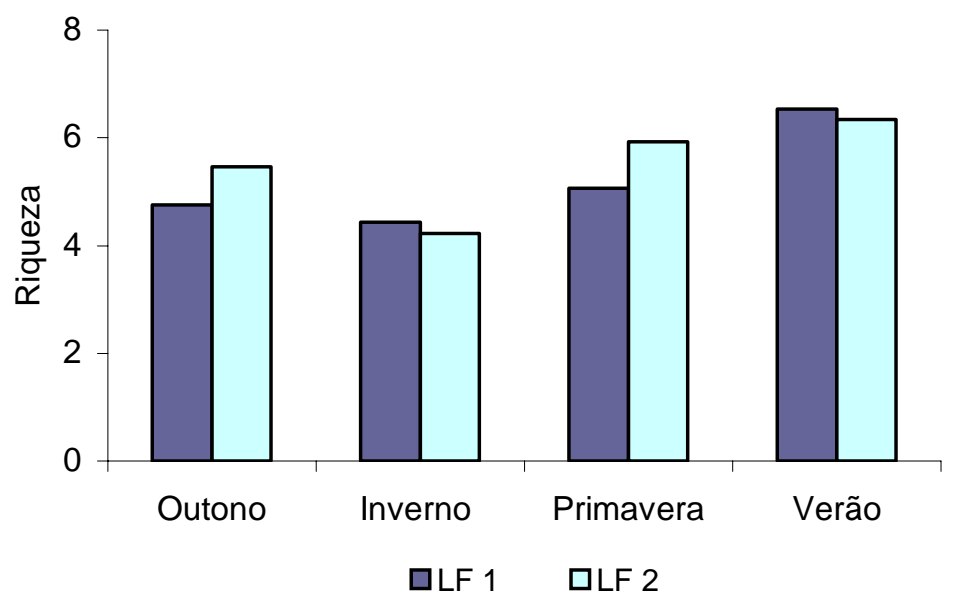

Figura 50: Índices de riqueza obtidos nas épocas amostradas nas lagoas facultativa 1 e facultativa 2 da ETE de Novo Horizonte, SP. 


\subsubsection{Biovolume}

O volume celular médio foi calculado para os organismos considerados dominantes, abundantes ou comuns em um ou mais períodos de estudos. O maior volume celular encontrado foi o de Aphanocapsa sp (Cyanophyceae), 26.124,9 $\mu^{3}$ e o menor, de Synechocystis sp (Cyanophyceae), $213 \mu^{3}$; os volumes médios das outras algas podem ser observados na Tabela 13.

Tabela 13: Dimensões médias, formas geométricas e volume celular médio dos organismos dominantes, abundantes e comuns presentes nas lagoas facultativa 1 e facultativa 2 da ETE de Novo Horizonte, SP, no período de estudo.

\begin{tabular}{|cccc|}
\hline Organismos & $\begin{array}{c}\text { Dimensões Médias } \\
(\mu \mathrm{m})\end{array}$ & $\begin{array}{c}\text { Formas Geométricas } \\
\text { Chlorella sp }\end{array}$ & $\begin{array}{c}\text { Volume Celular } \\
\text { Médio }\left(\mu^{3}\right)\end{array}$ \\
\hline Chlorella vulgaris & 8,15 & Esfera & 8499,0 \\
\hline Closteriopsis acicularis & 3,37 & Esfera & 600,0 \\
\hline Crucigeniella rectangularis & $2,75 \times 2,7 \times 2,6$ & $2 \times$ Cone & 3858,0 \\
\hline Dictyosphaerium sp & 6,3 & $12 \times$ Caixa retangular & 1980,0 \\
\hline Golenkinia radiata & 9,9 & $7,2 \times$ Esfera & 1360,8 \\
\hline Aphanocapsa sp & 11,85 & Esfera & 15234,0 \\
\hline Synechocystis sp & $1,8 \times 2,75$ & Esfera & 26124,9 \\
\hline
\end{tabular}

No outono, Aphanocapsa sp (Cyanophyceae) foi a espécie que mais contribuiu para a biomassa algal, atingindo um valor máximo de biovolume de 2.902.766,7 $\mu^{3}$, na superfície da primeira lagoa facultativa e a 0,7 $\mathrm{m}$ de profundidade da outra lagoa, ambos em t1 (Figura 51). 

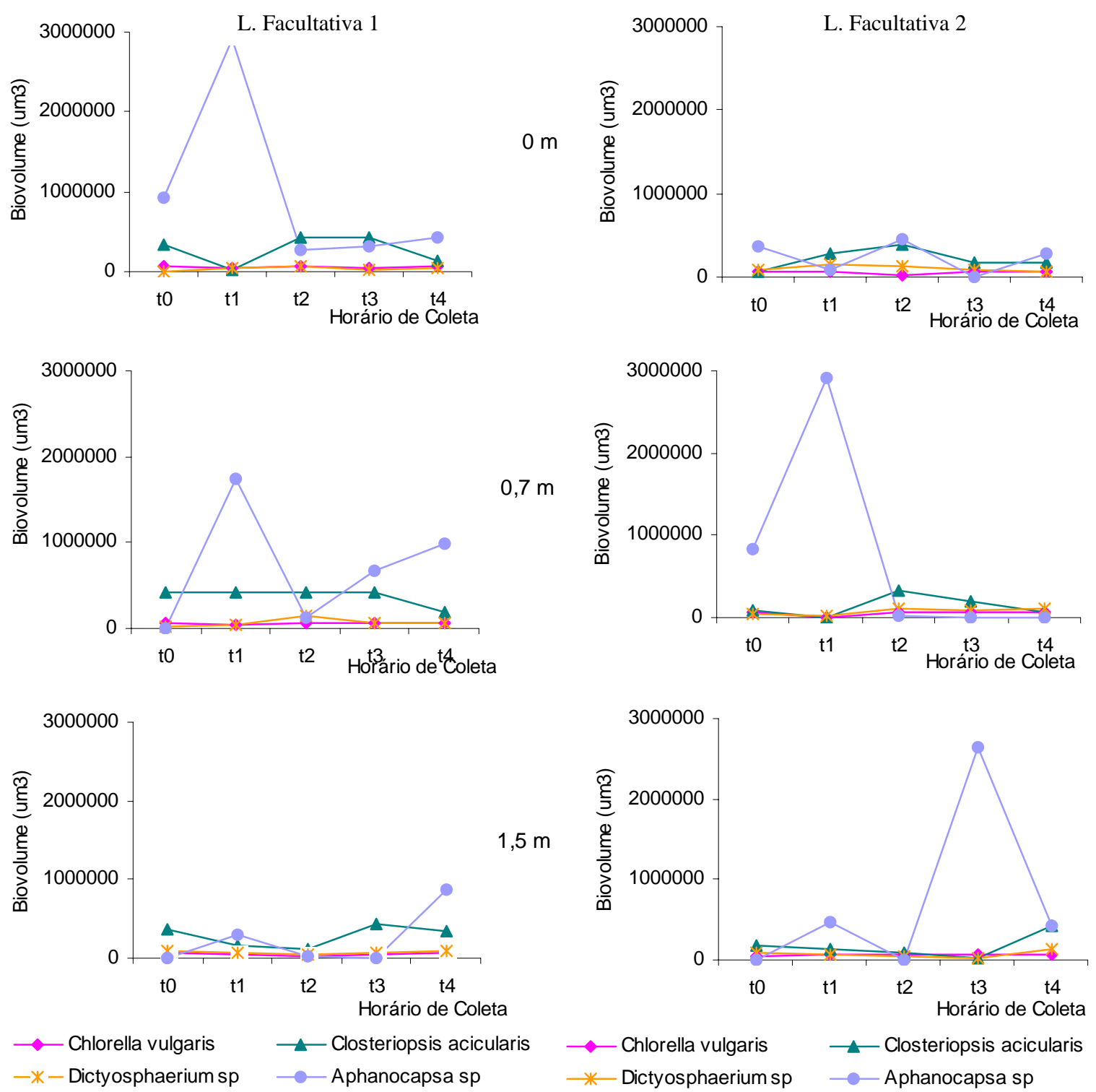

Figura 51: Biovolume das espécies mais representativas, nas lagoas facultativa 1 e facultativa 2 da ETE de Novo Horizonte, SP, no outono (maio/2002).

Na coleta que caracterizou o inverno, Chlorella vulgaris (Chlorophyceae) obteve a maior biomassa algal em todos os horários e profundidades das duas lagoas, com valor máximo de $426.000 \mu^{3}$ a 0,7 m de profundidade da lagoa facultativa 1, em t3 (Figura 52). 

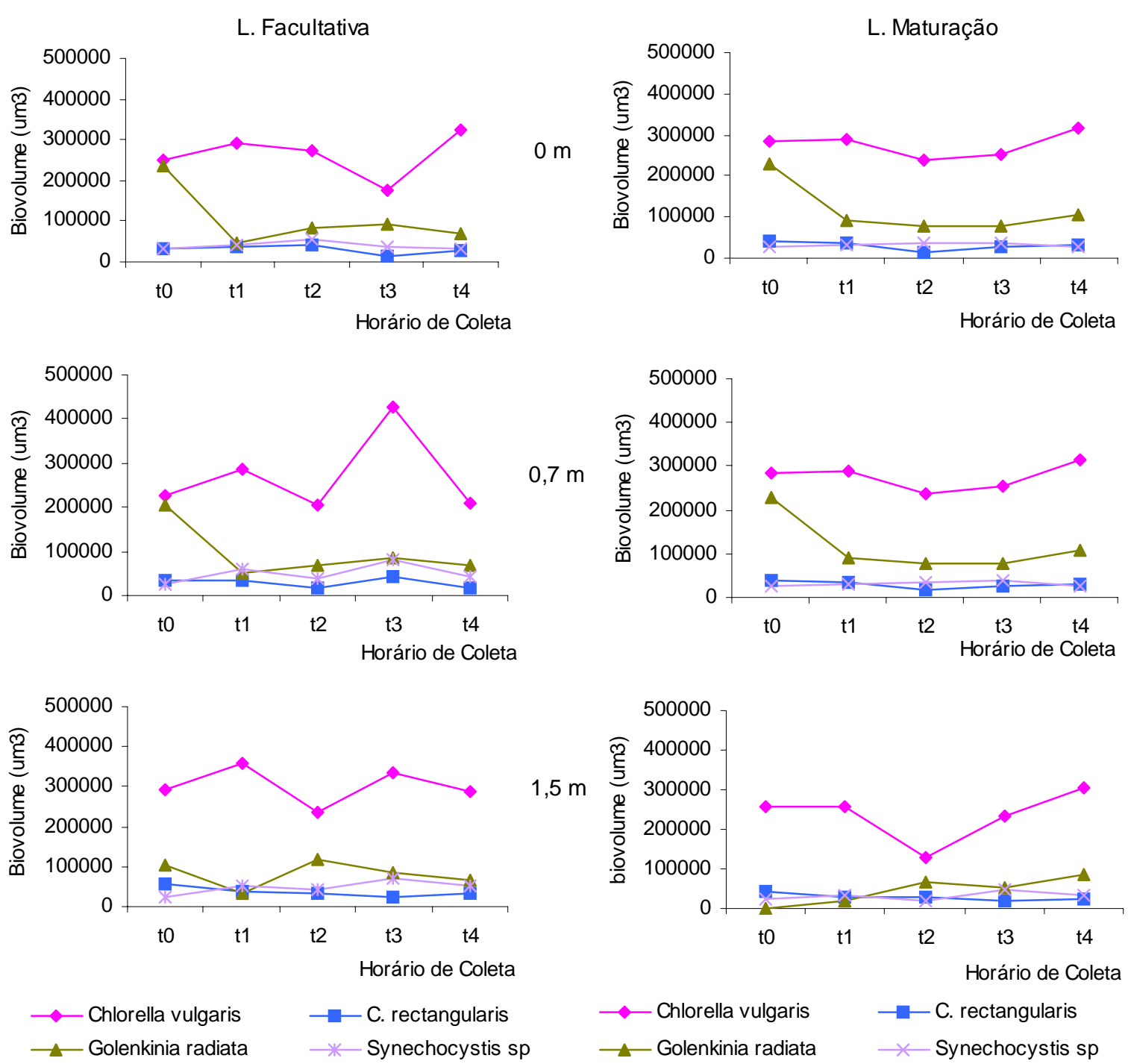

Figura 52: Biovolume das espécies mais representativas, nas lagoas facultativa 1 e facultativa 2 da ETE de Novo Horizonte, SP, no inverno (agosto/2002).

Na primavera, em E3, Golenkinia radiata (Chlorophyceae) predominou como a espécie com maior biomassa, exceto no fundo, em t4; sua maior contribuição ocorreu na superfície, em t0 $\left(829.406,7 \mu^{3}\right)$. No entanto, na outra lagoa, Golenkinia radiata (Chlorophyceae) e Chlorella sp (Chlorophyceae) se alternaram em maior contribuição, ao longo dos horários e das profundidades. O maior valor encontrado para a primeira foi registrado a $0,7 \mathrm{~m}$, em $\mathrm{t} 1\left(677.066,7 \mathrm{\mu m}^{3}\right)$; e para a outra, na superfície em t3 (585.486,7 $\mu^{3}{ }^{3}$ ) (Figura 53). 
L. Facultativa 1
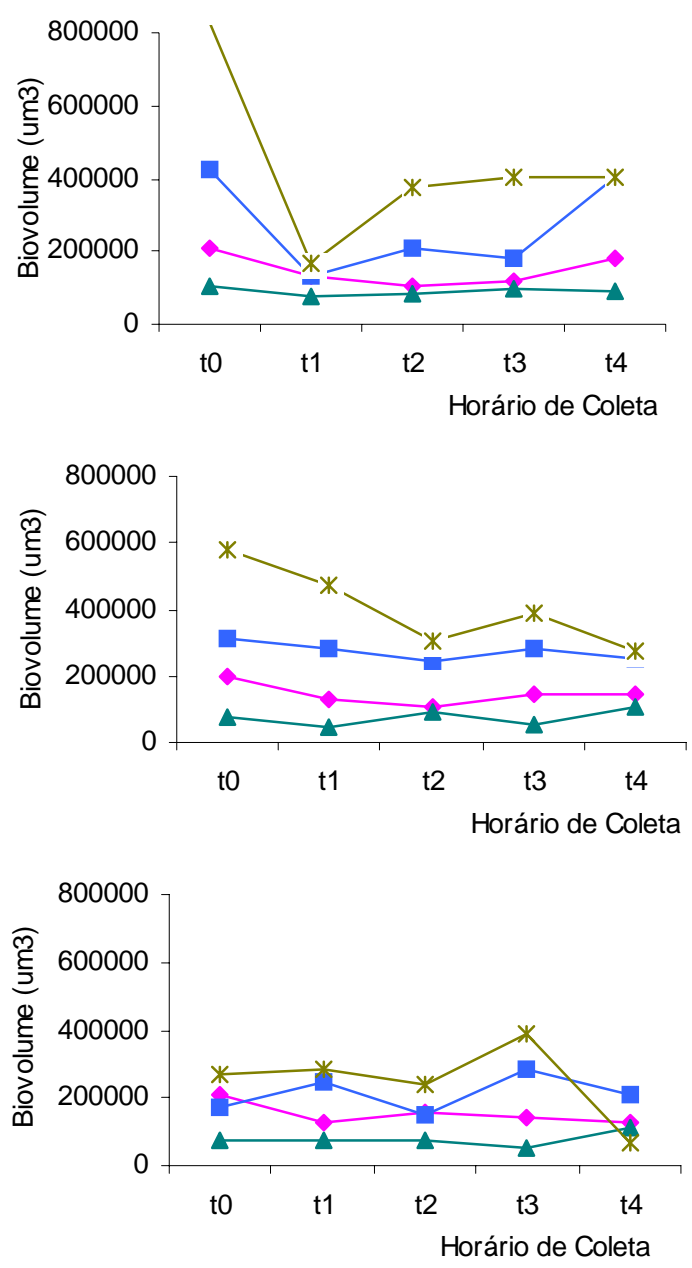

$\multimap$ Chlorella vulgaris $\rightarrow$ Chlorella sp

$\leftarrow$ Closteriopsis acicularis $\rightarrow$ Golenkinia radiata
L. Facultativa 2
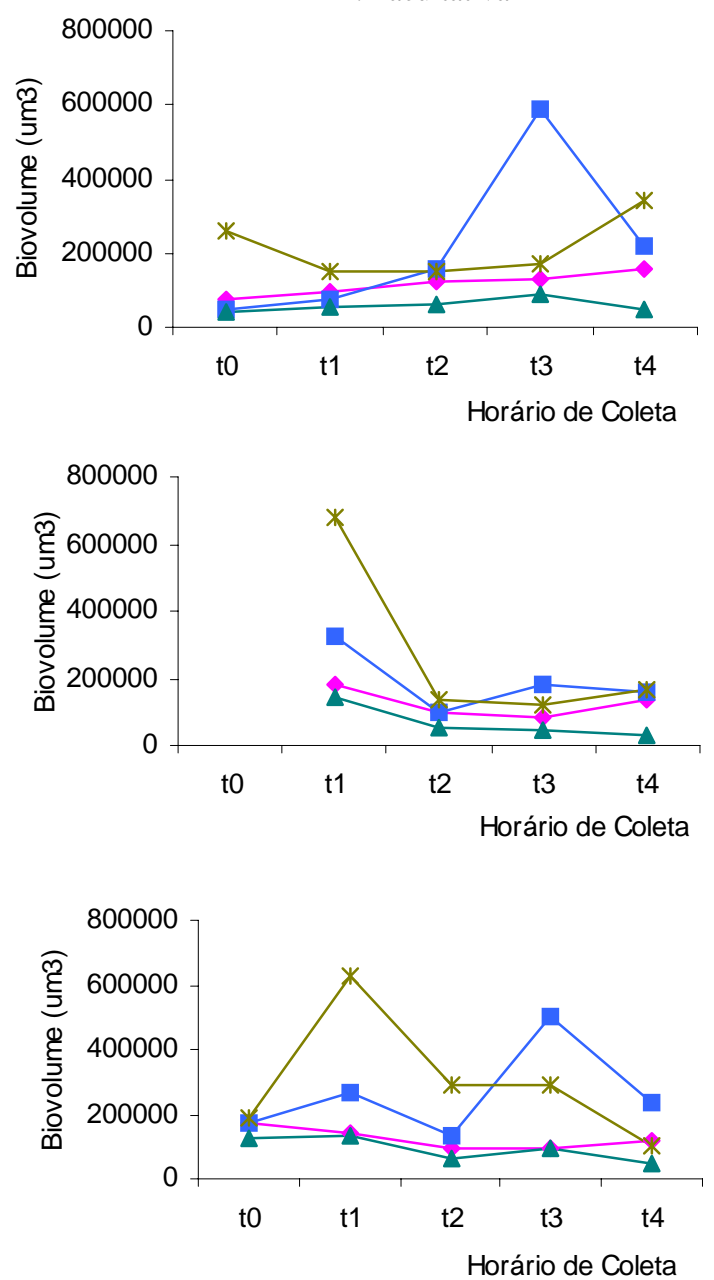

$\multimap$ Chlorella vulgaris $\quad \longrightarrow$ Chlorella sp

$\multimap$ Closteriopsis acicularis $\rightarrow$ * Golenkinia radiata

Figura 53: Biovolume das espécies mais representativas, nas lagoas facultativa 1 e facultativa 2 da ETE de Novo Horizonte, SP, na primavera (novembro/2002).

No verão, novamente Chlorella sp (Chlorophyceae) e Golenkinia radiata (Chlorophyceae) se alternaram na maior contribuição, ao longo das profundidades e dos horários, nas duas lagoas. As contribuições máximas para essas espécies foram encontradas no fundo da lagoa facultativa 1, em t4, 3.069.083,3 $\mu^{3}$ e 1.845.006,7 $\mu^{3}$, respectivamente (Figura 54). 

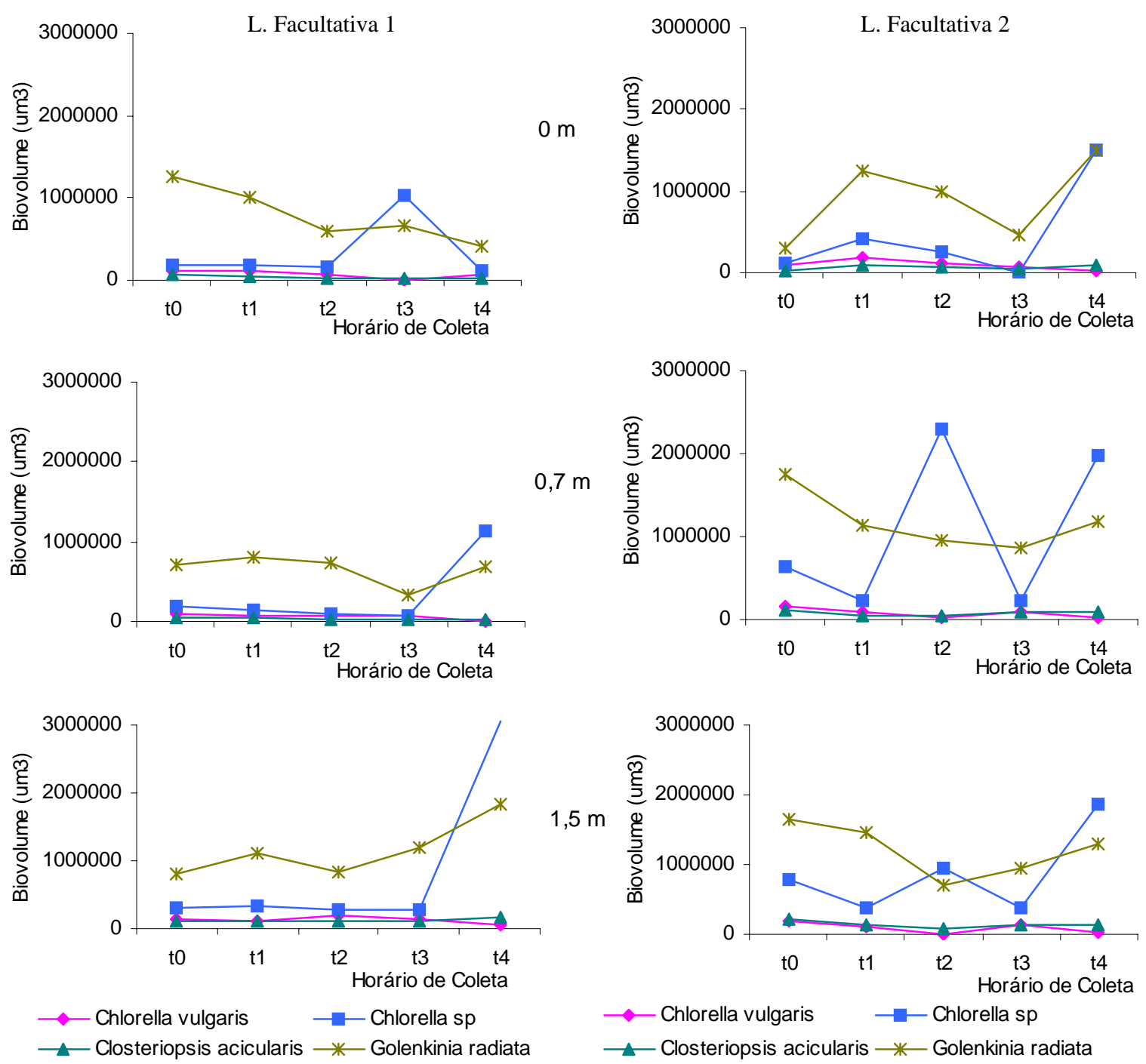

Figura 54: Biovolume das espécies mais representativas, nas lagoas facultativa 1 e facultativa 2 da ETE de Novo Horizonte, SP, no outono (maio/2002).

\subsubsection{Estrutura em Tamanho dos Organismos Pertencentes a Comunidade}

As médias das dimensões axiais máximas dos organismos mostraram que a composição de espécies do fitoplâncton das lagoas facultativa 1 e 2 e do efluente final do sistema era constituída por microplâncton e nanoplâncton. No primeiro grupo estavam incluídas 35,3\% das espécies encontradas, como Closteripsis acicularis, Golenkinia radiata, Oscillatoria sp, Euglena acus, Lepocinclis sp, entre outras. O segundo grupo foi composto por 64,7\% dos táxons encontrados, entre eles: Chlorella vulgaris, Chlorella sp, Aphanocapsa sp, duas espécies de Synechocystis e Lepocinclis ovum. 


\subsubsection{Clorofila a e Feofitina}

Foram observadas variações significativas nas concentrações de clorofila entre os períodos estudados (Apêndice A). As maiores oscilações foram encontradas entre o inverno e as demais épocas, pois nesse período foram registradas as maiores concentrações, cerca de três vezes maiores que as outras.

No outono foram encontradas as menores concentrações; a máxima desse período, na primeira lagoa facultativa, foi de 282,0 $\mu \mathrm{g} / \mathrm{L}$, obtida na superfície, em t4; e na lagoa facultativa 2, a 0,7 $\mathrm{m}$ de profundidade, em $\mathrm{t} 3$. Os menores valores foram encontrados no fundo das lagoas, com exceção de t2 em E4 (Figura 55).
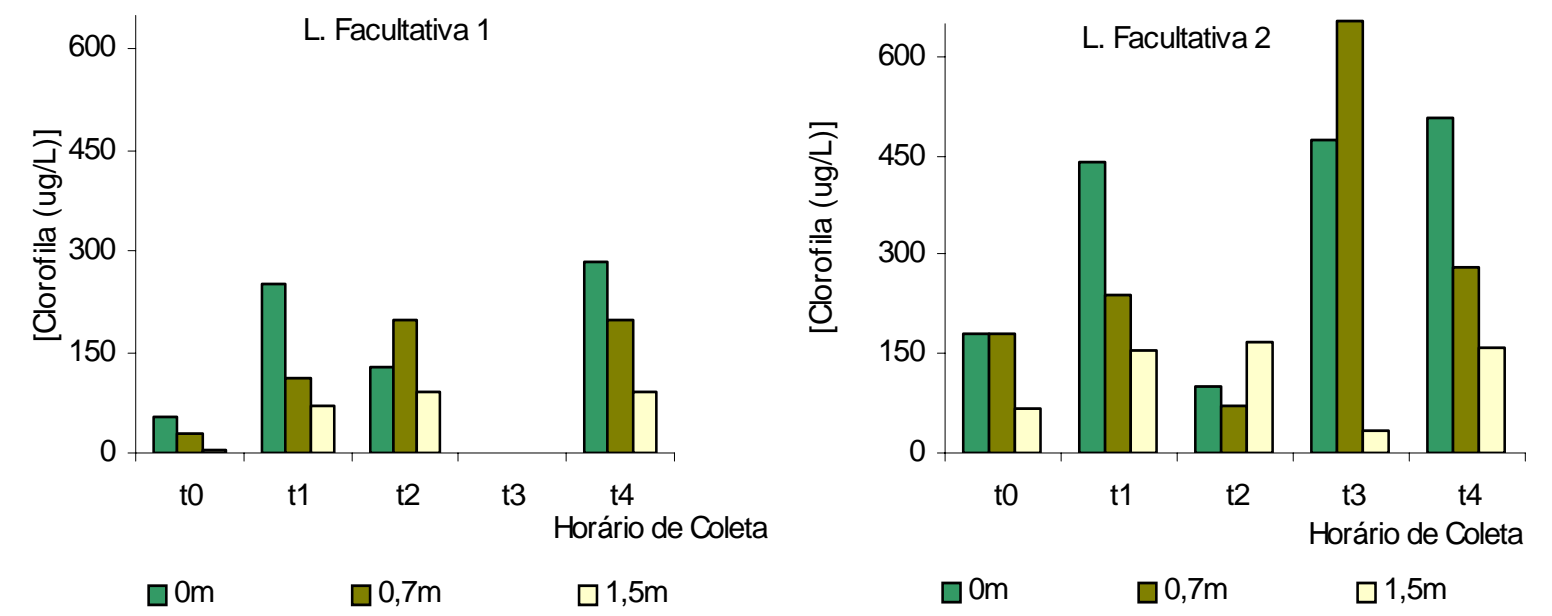

Figura 55: Variações na concentração de clorofila a ( $\mu \mathrm{g} / \mathrm{L})$, ao longo de 24h, nas lagoas facultativa 1 e facultativa 2, na ETE de Novo Horizonte, SP, no outono (maio/2002).

No inverno, foram encontradas as maiores concentrações de clorofila a. A primeira lagoa apresentou valores mais altos que a lagoa facultativa 2, sendo a concentração máxima de 5.139,2 $\mu \mathrm{g} / \mathrm{L}$, obtida na superfície, em t0; e na outra lagoa foi de 2.986,1 $\mu \mathrm{g} / \mathrm{L}$, encontrada no fundo em t4 (Figura 56). 

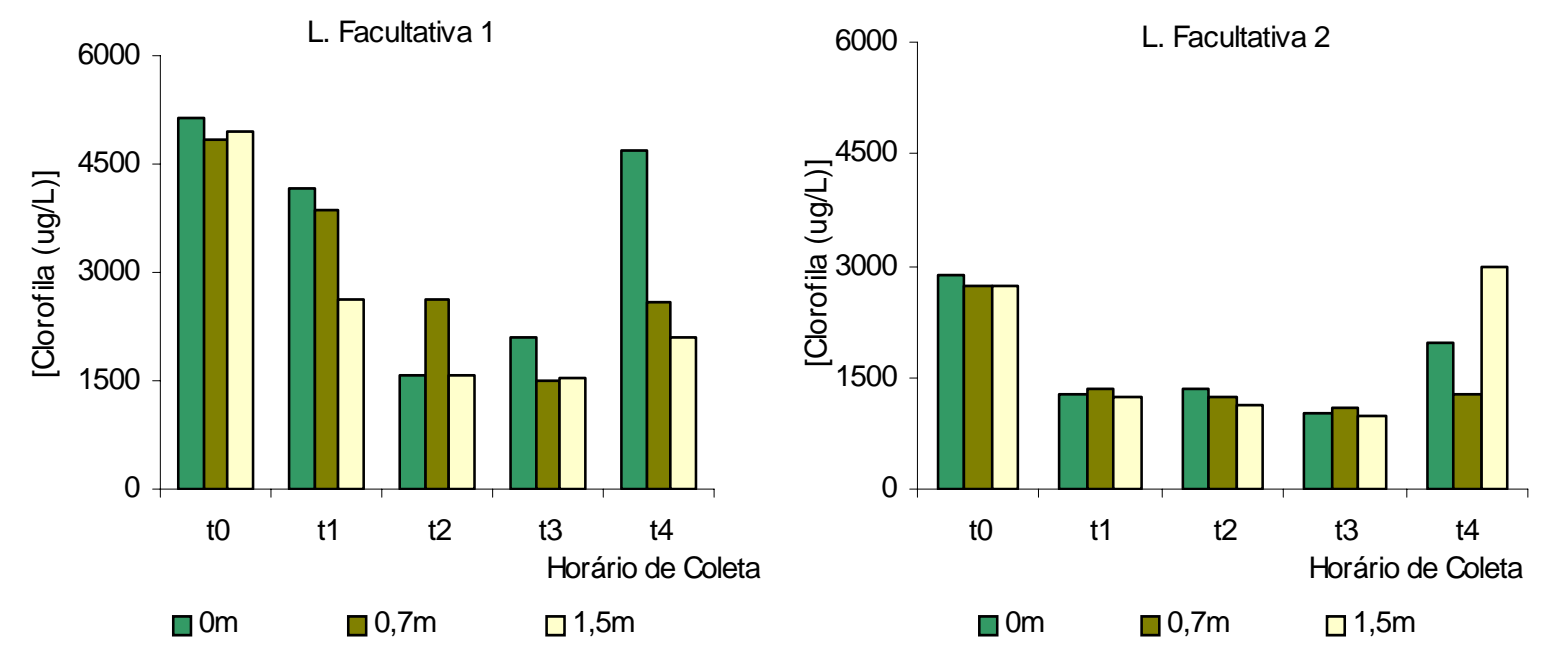

Figura 56:Variações na concentração de clorofila a ( $\mu \mathrm{g} / \mathrm{L}$ ), ao longo de 24h, nas lagoas facultativa 1 e facultativa 2, na ETE de Novo Horizonte, SP, no inverno (agosto/2002).

Na primavera, as concentrações variaram entre 378,1 $\mu \mathrm{g} / \mathrm{L}$, encontrada a $0,7 \mathrm{~m}$ de profundidade da segunda lagoa facultativa, em t0 e 1.203,1 $\mu \mathrm{g} / \mathrm{L}$, obtida no fundo da primeira lagoa, em t0 (Figura 57).
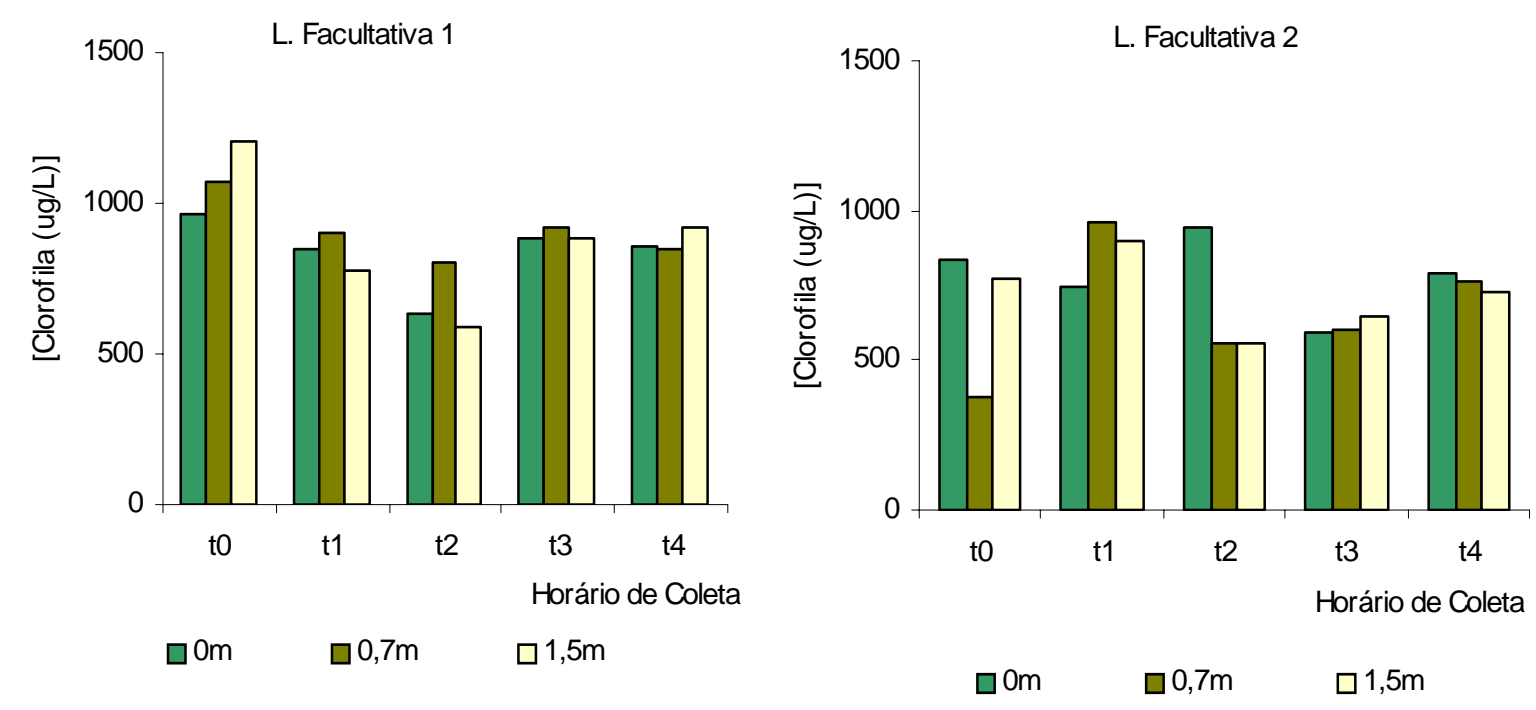

Figura 57: Variações na concentração de clorofila a ( $\mu \mathrm{g} / \mathrm{L})$, ao longo de 24h, nas lagoas facultativa 1 e facultativa 2, na ETE de Novo Horizonte, SP, na primavera (novembro/2002). 
Durante as coletas do verão, na lagoa facultativa 1, os valores encontrados durante o dia (t0, t1 e t4) foram muito maiores que os da noite. Nesta lagoa, o máximo foi registrado a $0 \mathrm{~m}$, em t1 $(1.683 \mu \mathrm{g} / \mathrm{L})$; enquanto que na outra lagoa, a maior concentração foi observada na mesma profundidade, em t3 (1.026,9 ㅆg/L) (Figura 58).
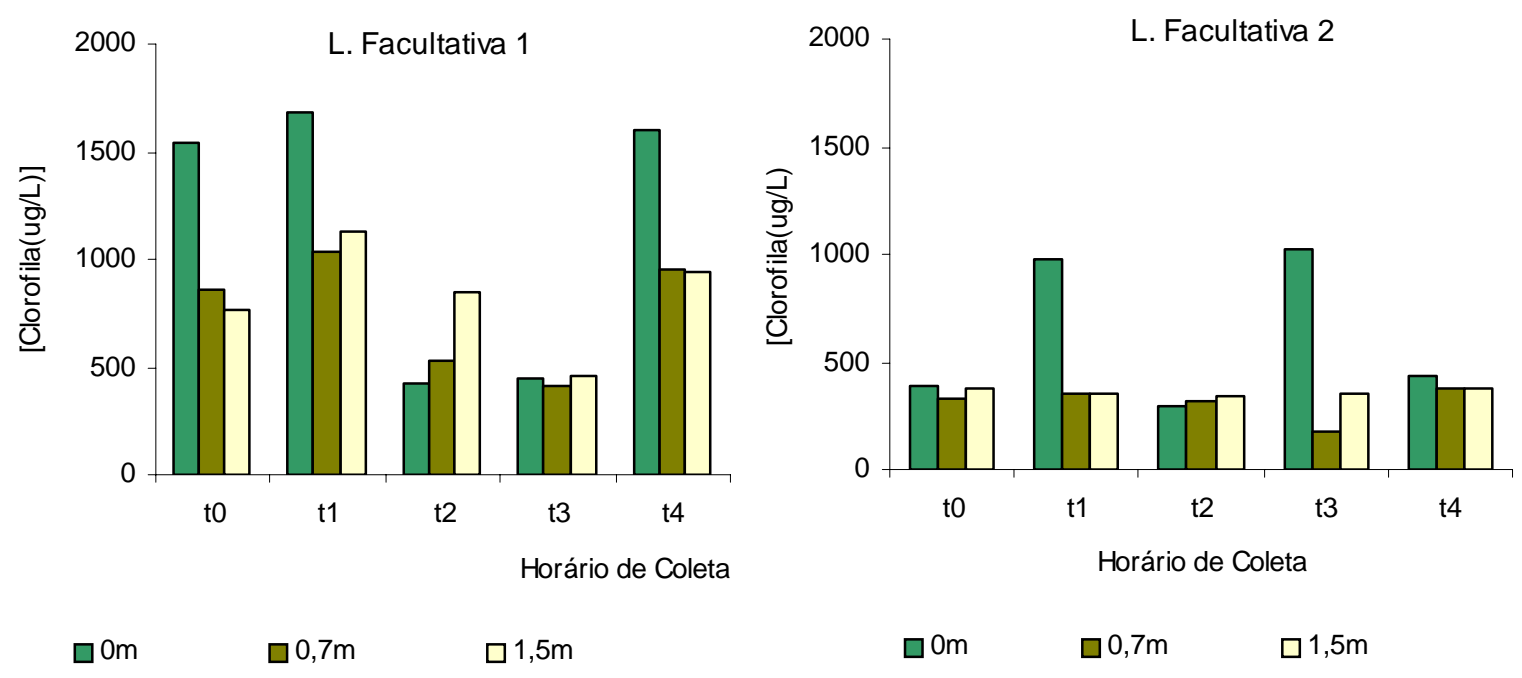

Figura 58: Variações na concentração de clorofila a ( $\mu \mathrm{g} / \mathrm{L})$, ao longo de $24 \mathrm{~h}$, nas lagoas facultativa 1 e facultativa 2, na ETE de Novo Horizonte, SP, no verão (fevereiro/2003).

As concentrações de feofitina também foram maiores no inverno, assim como ocorreu com a clorofila $a$.

No outono, o maior valor obtido na primeira lagoa foi de $1.172,7 \mu \mathrm{g} / \mathrm{L}$, a $0,7 \mathrm{~m}$ de profundidade, em t3. Na outra lagoa, o valor mais alto foi encontrado no fundo, em t2 (524,8 $\mu \mathrm{g} / \mathrm{L})$ (Figura 59). 


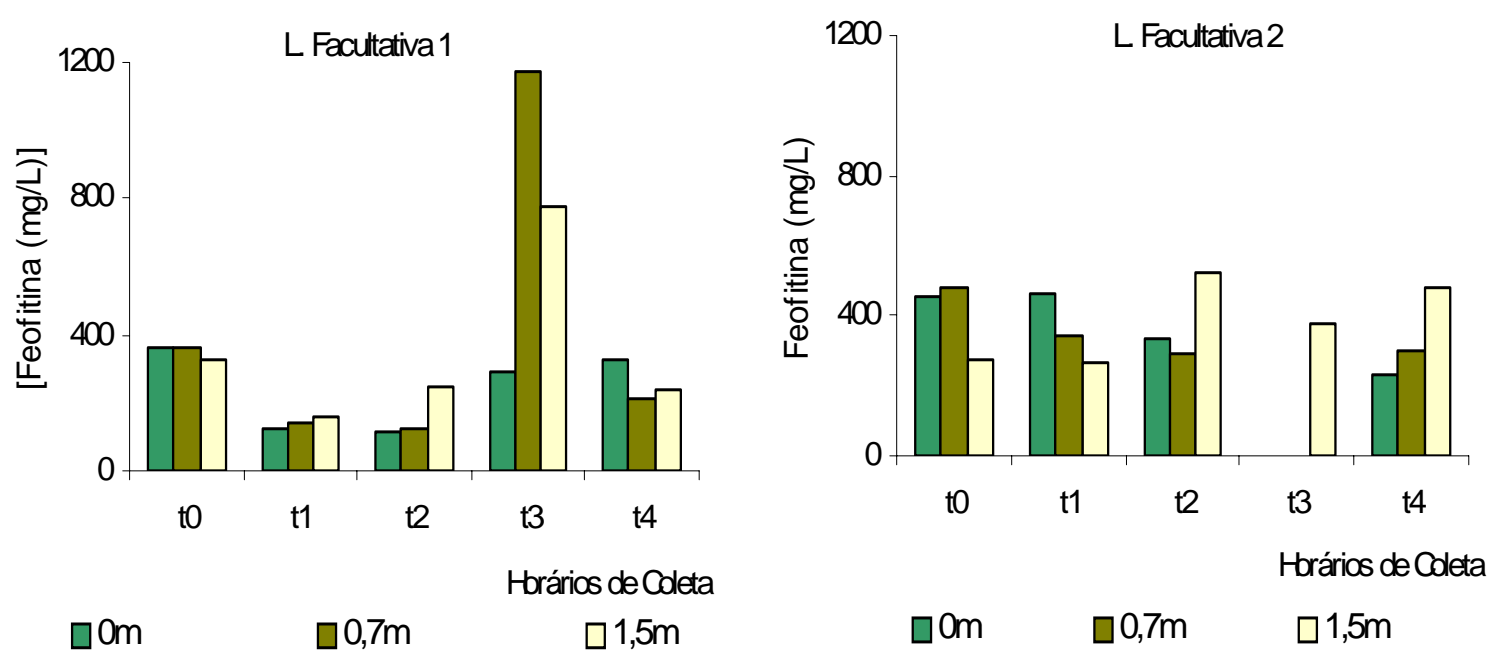

Figura 59: Variações na concentração de feofitina $(\mu \mathrm{g} / \mathrm{L})$, ao longo de 24h, nas lagoas facultativa 1 e facultativa 2, na ETE de Novo Horizonte, SP, no outono (maio/2002).

O período mais frio apresentou variações entre os horários nas três profundidades na lagoa facultativa 1 e no fundo na segunda lagoa. Na primeira lagoa, a maior concentração foi obtida na superfície, em 4 (998,8 $\mu \mathrm{g} / \mathrm{L})$ e na outra lagoa, no fundo, em t0 (749,9 $\mu \mathrm{g} / \mathrm{L})$ (Figura 60).

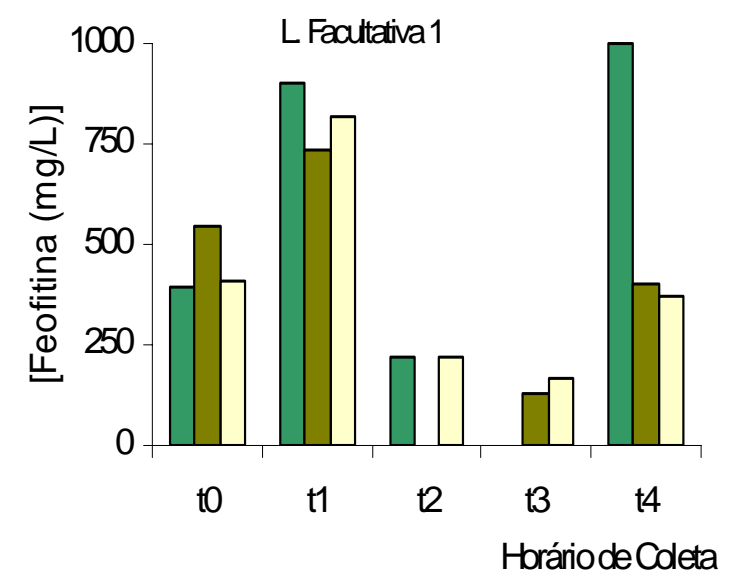

$\square 0 \mathrm{~m} \quad \square 0,7 \mathrm{~m} \quad \square 1,5 \mathrm{~m}$

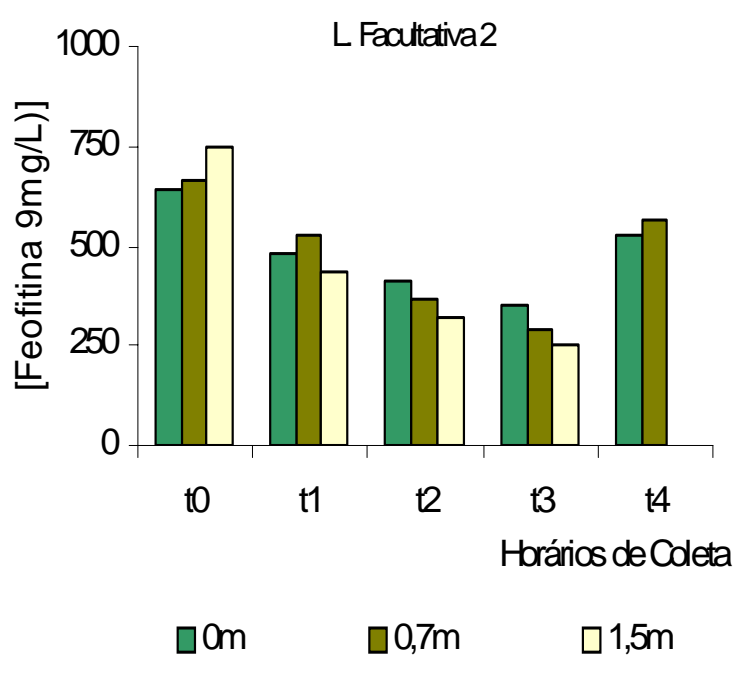

Figura 60: Variações na concentração de feofitina $(\mu \mathrm{g} / \mathrm{L})$, ao longo de 24h, nas lagoas facultativa 1 e facultativa 2, na ETE de Novo Horizonte, SP, no inverno (agosto/2002). 
Na primavera, na primeira lagoa facultativa, a maior concentração foi encontrada a $0,7 \mathrm{~m}$ de profundidade, em t0 $(342,7 \mu \mathrm{g} / \mathrm{L})$. Na segunda lagoa, foram observadas variações somente entre as concentrações obtidas a 0,7 m; nessa profundidade também foi encontrado o maior valor, 685,8 $\mu \mathrm{g} / \mathrm{L}$, em t0. (Figura 61)
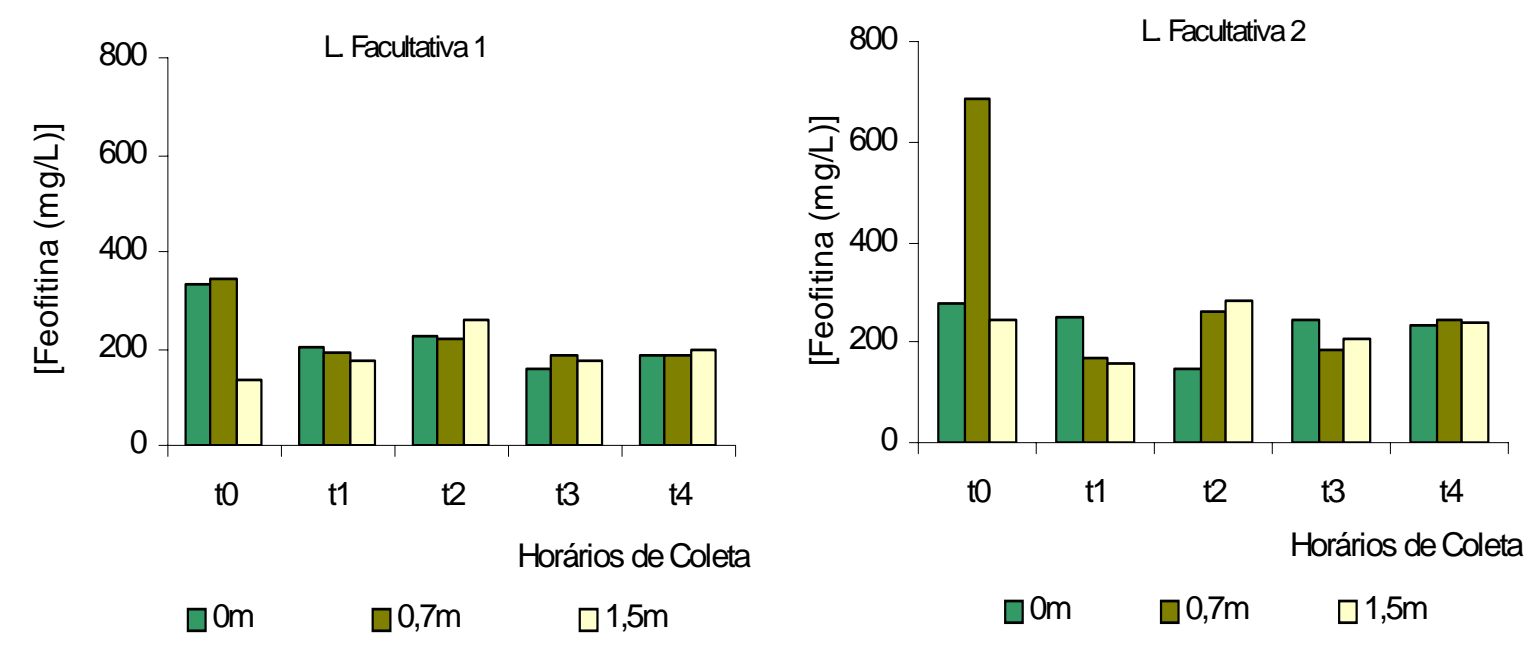

Figura 61: Variações na concentração de feofitina ( $\mu \mathrm{g} / \mathrm{L})$, ao longo de 24h, nas lagoas facultativa 1 e facultativa 2, na ETE de Novo Horizonte, SP, na primavera (novembro/2002).

O verão apresentou variações entre os horários nas concentrações da superfície da lagoa facultativa 1. Nesta lagoa, o maior valor foi obtido a 0 m, em t4 (911,3 $\mu \mathrm{g} / \mathrm{L})$ e na outra lagoa, na mesma profundidade em t1 (282,1 $\mu \mathrm{g} / \mathrm{L})$ (Figura 62). 


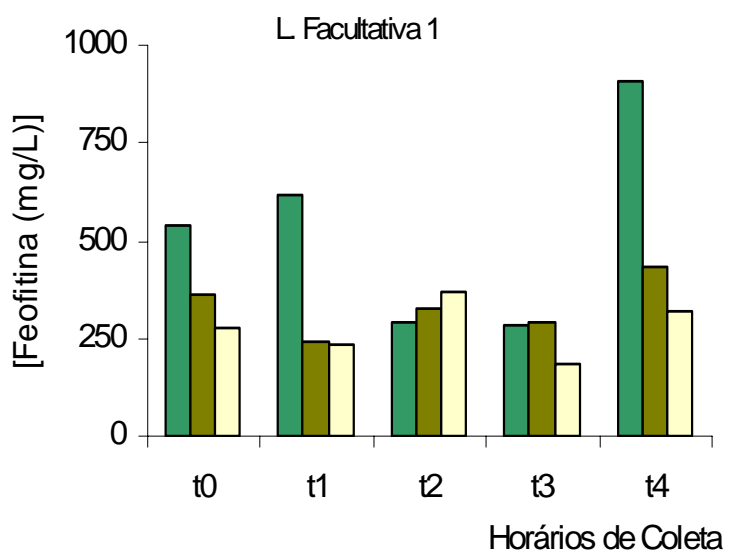

$\square 0 \mathrm{~m} \quad \square 0,7 \mathrm{~m}$

$\square 1,5 \mathrm{~m}$

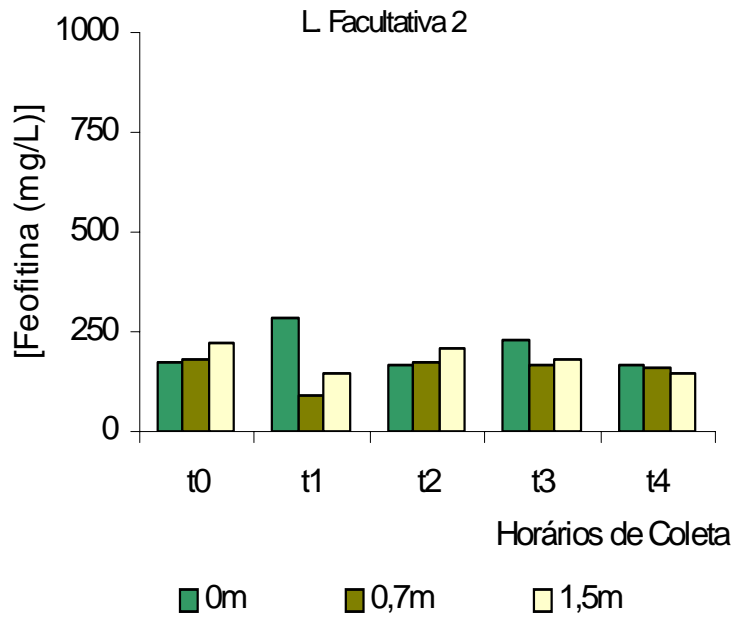

Figura 62: Variações na concentração de feofitina ( $\mu \mathrm{g} / \mathrm{L})$, ao longo de 24h, nas lagoas facultativa 1 e facultativa 2, na ETE de Novo Horizonte, SP, no verão (fevereiro/2003). 


\section{DISCUSSÃO}

\subsection{Variáveis Físico-Químicas}

Com vistas a entender e comparar as flutuações temporais das variáveis ambientais, as lagoas de estabilização podem ser consideradas como ecossistemas lênticos rasos e hipereutróficos, apesar de possuírem características físicas, químicas e biológicas típicas, conseqüentes da elevada carga orgânica.

Em regiões tropicais e subtropicais, a precipitação é considerada por muitos autores como a variável ambiental que apresenta maior diferença de intensidade ao longo do ano. Nestes locais distinguem-se basicamente dois períodos: um período seco e outro marcado pela abundância de chuvas. Essa variável climatológica pode ser considerada fator relevante na composição de espécies fitoplanctônicas, uma vez que a temperatura tende a ser mais ou menos constante durante as estações do ano; a precipitação teve marcada importância neste estudo, em que condutividade, oxigênio dissolvido, nutrientes ( $\mathrm{N}$ e P) e carga orgânica não apresentaram variações significativas entre os períodos do ano.

As coletas do outono e do inverno foram precedidas por meses de baixas precipitações; os meses de abril e junho transcorreram sem chuvas e valores mínimos foram obtidos entre maio $\left(60 \mathrm{~mm}^{3}\right)$ e agosto $\left(35 \mathrm{~mm}^{3}\right)$. De setembro em diante as chuvas começaram a aumentar, atingindo $124 \mathrm{~mm}^{3}$ no mês que antecedeu a coleta da primavera e $534 \mathrm{~mm}^{3}$ antes da coleta do verão.

É provável que as chuvas tenham contribuído para os maiores valores de profundidade de desaparecimento do disco de Secchi, encontrados no verão $(0,27 \mathrm{~m}$, em t1 e 0,20 m, em t4), devido ao seu efeito diluidor nas lagoas; como conseqüência, nesse período foram encontradas as maiores zonas eufóticas (0,81 m, em t1 e 0,60 m, em t4) e os menores coeficientes de atenuação do contraste vertical. Como argumento adicional a esse efeito diluidor, no inverno, período com quase total ausência de precipitação, foram obtidos os menores valores de profundidade de desaparecimento do Secchi que não ultrapassaram 0,09 m; a excessiva concentração de material suspenso presente nas lagoas, incluindo as algas, foi responsável por esses valores de Secchi tão pequenos. Ferreira (1988) encontrou, nas lagoas da Estação do Guará I (Brasília, DF), valores muito baixos para a profundidade de desaparecimento do disco de Secchi, que variaram entre 0,08 e $0,15 \mathrm{~m}$. 
As variações horárias de temperatura, $\mathrm{pH}$ e oxigênio dissolvido, geralmente parecem seguir o padrão cíclico diurno natural, controlado pela intensidade da luz solar incidente, nos processos que ocorrem nas lagoas.

Segundo Branco (1986), a temperatura do líquido de uma lagoa de estabilização acompanha a variação da temperatura do ambiente, no entanto, as camadas mais profundas se mantêm mais estáveis. No local de estudo, as temperaturas registradas foram relativamente altas; mesmo no período de inverno estiveram acima dos $22^{\circ} \mathrm{C}$. Gomes (2002), também encontrou temperaturas elevadas (acima de $21^{\circ} \mathrm{C}$ ), mesmo em períodos mais frios para outras lagoas de estabilização situadas na região deste estudo; o fato do clima local ser quente, com temperatura média anual em torno de $25^{\circ} \mathrm{C}$, justifica as altas temperaturas observadas nas lagoas.

Altas temperaturas aceleram o metabolismo dos microrganismos e, conseqüentemente, aumentam a velocidade de degradação dos compostos orgânicos. Por outro lado, no entanto, elas diminuem a solubilidade do oxigênio dissolvido nos líquidos.

Segundo Von Sperling (1996b), as lagoas de estabilização podem apresentar estratificação térmica, ou seja, a camada superior mais quente, não se mistura com a inferior, mais fria, ocasionando também estratificação química e diferenças de biomassa na coluna de água. No ecossistema investigado foram observadas algumas variações mais pronunciadas de temperatura, entre a superfície e o fundo das lagoas, em alguns horários e períodos de coleta: no outono, variação de $4^{\circ} \mathrm{C}$ na facultativa 1 e de $6^{\circ} \mathrm{C}$ na facultativa 2, ambas em t1 (15:30 h), porém essas estratificações não foram constantes; no verão, na primeira lagoa, ocorreram variações de $4^{\circ} \mathrm{C}$ em t0, t1 e t2 e na facultativa 2 , de $5^{\circ} \mathrm{C}$ em t0 e t2 e de $9^{\circ} \mathrm{C}$ em $\mathrm{t} 1$, essas consideradas como estratificações relativamente constantes, pois permaneceram desde as 9:30 h até por volta das 22:00 h.

Essas diferenças de $4^{\circ} \mathrm{C}$ a $9^{\circ} \mathrm{C}$, observadas entre a superfície e o fundo das lagoas, são reconhecidas por muitos autores como sendo uma variação que pode levar à estratificação térmica na coluna de água. Henry (1990) afirmou que o decréscimo de temperatura por si só, não caracteriza o surgimento de termoclina e citou o conceito de Birge segundo o qual, para que esta ocorra é necessária diminuição de $1^{\circ} \mathrm{C} / \mathrm{m}$ para zonas temperadas e de $0,1^{\circ} \mathrm{C} / \mathrm{m}$ a $0,2^{\circ} \mathrm{C} / \mathrm{m}$ em águas tropicais. No entanto, as diferenças encontradas não foram significativas; não foram observadas variações entre horários, profundidades e períodos de coletas, nem mesmo entre inverno e verão (Apêndice A). 
Em ambientes como o que foi estudado, a baixa profundidade do sistema e a alta carga orgânica, aliadas à alta temperatura, contribuem para marcada desoxigenação da água. Esse fato foi observado nos horários de coleta t2 (21:30h) e t3 (3:30h); no entanto, nas horas mais quentes do dia, devido à produção fotossintética de oxigênio, a concentração de oxigênio dissolvido nas camadas superficiais pode alcançar $35 \mathrm{mg} / \mathrm{L}$ (UEHARA e VIDAL, 1989). A concentração máxima desse gás, medida nas amostras coletadas neste trabalho foi de $13 \mathrm{mg} / \mathrm{L}$, registrada em $\mathrm{t} 1$ (15:30h) na coleta de verão. Cabe ressaltar que, para todos os períodos e horários de coleta, foram registradas concentrações insignificantes de oxigênio dissolvido abaixo dos 0,6 m de profundidade.

Altos valores de condutividade elétrica são comuns em águas poluídas. Para lagoas de estabilização, o aumento desta variável torna-se ainda mais acentuado, porque no processo de decomposição da matéria orgânica há liberação de substâncias inorgânicas responsáveis por elevar a condutividade elétrica da água (GOMES, 2002). Os valores desse parâmetro encontrados neste estudo, para as lagoas facultativas 1 e 2, oscilaram entre $720 \mu \mathrm{S} / \mathrm{cm}$ e $900 \mu \mathrm{S} / \mathrm{cm}$. No verão, a lagoa facultativa 2 apresentou oscilações mais pronunciadas dessa variável entre os horários e as profundidades (900 $\mu \mathrm{S} / \mathrm{cm}$ e $1030 \mu \mathrm{S} / \mathrm{cm}$ ). Gomes (op cit.), em trabalho realizado em quatro ETEs, encontrou para condutividade valores entre $800 \mu \mathrm{S} / \mathrm{cm}$ e $1300 \mu \mathrm{S} / \mathrm{cm}$ no esgoto afluente e entre $700 \mu \mathrm{S} / \mathrm{cm}$ e $1000 \mu \mathrm{S} / \mathrm{cm}$ no efluente.

A concentração de sólidos suspensos no esgoto sanitário é extremamente elevada e, segundo Metcalf e Eddy (1991), cerca de 75\% deles são orgânicos. Mara (1995) reporta que de 60 a 90\% do material em suspensão presente em lagoas facultativas são algas. Neste trabalho, os sólidos suspensos orgânicos representaram mais de $80 \%$ dos totais em todas as estações, horários e períodos de coleta. As concentrações de sólidos suspensos totais presentes nas saídas da lagoa anaeróbia (E2) não apresentaram variações significativas entre os períodos de estudo, entretanto, as concentrações encontradas nas lagoas apresentaram oscilações entre o inverno e todos os demais períodos, sendo que as maiores ocorreram entre o inverno e o verão. Isso indica que o fator que nas lagoas contribuiu para essa flutuação foram a densidade e a biomassa algal, com valores muito mais altos no período frio, como mostra as Figuras 43 e 52. 
Houve eficiência na remoção dos sólidos em suspensão do esgoto afluente para o efluente, observada em todos os períodos de coleta através de análise estatística apresentada no Apêndice A; no entanto, em alguns horários, como em t0 (9:30 h) no inverno, as lagoas apresentaram concentrações maiores que no afluente, devido à alta densidade e biomassa algal. Wrigley e Toerien (1990), em estudos realizados em lagoas de estabilização, também encontraram concentrações médias de sólidos em suspensão maiores na segunda lagoa do que na primeira do sistema.

Em lagoas de estabilização, o pH tende a variar com a profundidade e ao longo do dia, por ser variável dependente da fotossíntese e da respiração. A atividade fotossintética faz essa variável aumentar e a decomposição a faz diminuir. Os valores de $\mathrm{pH}$ encontrados nas lagoas estudadas variaram entre 6 e 10 e, como era esperado, os mais altos valores foram observados nas horas mais quentes do dia, diminuindo ao anoitecer. Von Sperling (1996b) corrobora essas afirmações ao descrever que nas horas mais quentes do dia, período de máxima atividade fotossintética, o $\mathrm{pH}$ pode atingir valores em torno de 10; e sob estas condições podem ocorrer precipitações de fosfatos, o que é bom para o sistema, por contribuir para remoção de nutrientes e para conversão de sulfeto, que exala mau cheiro, a bissulfeto que é inodoro.

Kayombo et al. (2002) acreditam que o nível de pH nas lagoas pode ser usado como indicador da performance do sistema; $\mathrm{pH}$ acima de 8 seria conseqüência de taxa fotossintética que demanda mais dióxido de carbono do que as quantidades que são repostas pela respiração e decomposição; $\mathrm{pH}$ abaixo de 8 indica que a fotossíntese está sendo insuficiente para utilizar todo o dióxido de carbono produzido, o que alerta para a presença de altas concentrações desse gás.

A disponibilidade de nutrientes não pode ser considerada fator limitante para o crescimento do fitoplâncton em lagoas de estabilização, pois nestes ambientes suas concentrações tendem a ser bastante elevadas especialmente as de nitrogênio e fósforo que são os principais nutrientes essenciais para essa comunidade; sendo a relação N/P fator considerado relevante nos estudos de ecologia de espécies fitoplanctônicas.

As concentrações de fósforo nas lagoas não apresentaram variação significativa nos períodos estudados e na maioria dos horários e profundidades de coletas, oscilou entre 16,0 e $20 \mathrm{mg} / \mathrm{L}$; somente no inverno e no verão foram observados horários com valores significativamente menores que nos outros: no inverno, concentrações entre 6,0 e 13,5 mg/L em t4 (9:30 h) e no verão, concentrações entre 6,0 e 9,5 mg/L, em t0 (9:30 h). 
O ortofosfato foi o nutriente que mais apresentou variações entre os horários de coleta. Em todos os períodos foram observados aumentos dessa substância nas coletas noturnas, exceto no verão em que todos os horários mostraram valores altos (entre 2,0 $\mathrm{mg} / \mathrm{L}$ e 4,0 mg/L). Este aumento de fosfato registrado à noite, provavelmente, está relacionado à desoxigenação total da massa de água observada naqueles horários, pois na ausência de oxigênio, o fosfato férrico formado quando o ambiente se encontrava aeróbio dissocia-se em íon $\mathrm{Fe}^{3+}$ e $\mathrm{PO}_{4}$, que são solúveis em água; como o sistema é raso, a ação do vento devolve o fosfato à coluna de água.

As concentrações de nitrogênio não apresentaram variações entre os períodos. Apenas no outono, na superfície da segunda lagoa facultativa, foi observado um valor muito acima dos demais $(100,5 \mathrm{mg} / \mathrm{L})$. De modo geral, as concentrações obtidas no inverno foram apenas levemente mais altas que as das outras épocas.

Normalmente, em corpos de água de regiões temperadas, o nitrogênio tende a ser fator limitante para o fitoplâncton, enquanto que em ambientes tropicais o fósforo costuma ser mais escasso, devido à constituição das rochas de cada região. Mas, para ecossistemas como lagoas de estabilização, ambos os nutrientes se apresentam em concentrações bastante elevadas.

A DBO é considerada uma das variáveis mais importantes para se avaliar a eficiência do tratamento de esgoto doméstico; suas análises, junto com as de DQO e de sólidos suspensos, são as mais freqüentemente realizadas nas ETEs para acompanhar a eficiência do sistema.

No presente estudo, os valores de DBO apresentaram oscilações significativas entre as estações do ano, somente na saída da lagoa anaeróbia e na segunda lagoa facultativa (Apêndice A). No outono foram registrados resultados mais altos (médias de 253,5 mg/L em E3S e 277,5 mg/L em E4S) e os menores foram encontrados no inverno (médias de 132,0 mg/L na primeira lagoa e 130,0 na outra). A eficiência do sistema na remoção de DBO foi observada em todos os períodos de estudo, através do coeficiente de variação entre a concentração no afluente e no efluente (Apêndice A). 


\subsection{Variáveis Biológicas}

As lagoas de estabilização diferem dos corpos de água naturais e dos reservatórios artificiais por possuírem elevadas concentrações de nutrientes e clorofila, altas densidades de populações fitoplanctônicas, curto tempo de detenção hidráulico e altos valores de condutividade elétrica, o que as caracterizam como sistemas aquáticos rasos e hipereutróficos. Esses aspectos devem condicionar a comunidade fitoplanctônica, pois segundo Hutchinson (1957), a distribuição e a abundância de espécies em determinado ambiente estão relacionadas à tolerância destas às condições físicas e às interações existentes entre os microrganismos. Deste modo, as espécies capazes de responder às características do ambiente são favorecidas.

Os organismos fitoplanctônicos encontrados no sistema estudado estão entre os descritos como tolerantes a altas cargas orgânicas por muitos autores, entre eles Branco (1975 e 1986), Silva e Mara (1979) e Palmer (1969 e 1980). Segundo Konig (1984) e Palmer (op. cit.), as algas freqüentemente encontradas no esgoto pertencem à Chlorophyceae, Cyanophyceae, Euglenophyceae e Bacillariophyceae.

De acordo com Palmer (1969 e 1980) e Konig (op cit.) a composição de espécies fitoplanctônicas em ambientes com elevado grau de poluição orgânica é mais influenciada pelos resíduos orgânicos do que por outros fatores ambientais como pH e oxigênio dissolvido. Neste estudo, a constituição do fitoplâncton pode ter sido influenciada também pela ação do vento e pelas chuvas, uma vez que temperatura, condutividade e $\mathrm{pH}$ apresentaram variações insignificantes ao longo dos períodos de estudo. Giani e Figueiredo (1999) e Souza (2000) salientaram a forte influência da precipitação sobre a composição e a biomassa algal, pois atua como fator diluidor e perturbador das comunidades aquáticas.

A classe com maior número de organismos identificados neste estudo foi Chlorophyceae, com 15 espécies, seguida de Cyanophyceae, com 12, 4 de Euglenophyceae e 2 de Bacillariophyceae. Considerando esses ambientes apenas como sistemas de regiões tropicais, há concordância dos dados obtidos com os relatos de Kalff e Watson (1986), que enfatizaram ser esse o grupo com maior riqueza em algas planctônicas de lagos dessas regiões e correspondem a quase metade dos gêneros na listagem do fitoplâncton tropical. Ademais, Palmer (1980) destacou vários trabalhos em lagoas de estabilização em que essa classe correspondeu a mais de $50 \%$ dos organismos registrados. 
As diatomáceas estiveram pouco representadas neste estudo, tendo sido encontradas apenas duas espécies. Segundo Ferreira (1988), esse grupo é comum em lagoas de estabilização de regiões frias, mas, por outro lado, são pouco mencionadas em lagoas brasileiras.

A densidade fitoplanctônica apresentou variações significativass entre todos os períodos estudados (Apêndice A). No outono, foram registradas as menores densidades deste estudo, com valor total máximo de 62.954,5 org/mL. Nesse período, como nos demais, Chlorophyceae foi a classe dominante e Chlorella vulgaris a espécie predominante; apenas por duas vezes Cyanophyceae apresentou valores maiores, uma vez na superfície da lagoa facultativa 1, em t1 e outra no fundo da segunda lagoa, em t3. Com relação ao biovolume, esta foi a única época de estudo em que uma espécie de cianobactérias, Aphanocapsa sp, contribuiu com as maiores biomassas.

Um fator determinante no crescimento de Cyanophyceae é a estabilidade na coluna de água; sua densidade tende a subir quando há aumento da estabilidade e da temperatura da água. No Lago das Garças, Aphanocapsa sp esteve presente somente nos períodos de seca, mostrando ser uma das espécies que apresentou maior densidade no outono (BICUDO et al., 1999). Reynolds (1996) descreveu esse gênero como sendo bem adaptado a águas calmas, com moderadas concentrações de nutrientes. Essas afirmações podem explicar o fato de Apahanocapsa sp ter contribuído com maior biomassa no outono e de Cyanophyceae ter apresentado, em alguns horários desse período, densidade superior que à de outros grupos, pois a chuva pode ter agido como agente perturbador da estrutura da comunidade, desfavorecendo as algas azuis nos demais períodos. Alem disso, no outono foram encontrados as menores concentrações de DBO.

Naquele período, a densidade algal presente na primeira lagoa demonstrou correlação positiva com as concentrações de sólidos suspensos e nitrogênio; e negativa com a DBO e a concentração de fósforo (Apêndice B).

Nas demais épocas de coleta, as algas verdes dominaram sem exceção, tanto em densidade quanto em biomassa. Palmer (1980) ressaltou a predominância deste grupo em sistemas de lagoas de estabilização, onde corresponderam a mais da metade do fitoplâncton presente. 
Bicudo et al. (1999) descreveram que as clorofíceas são beneficiadas pela diminuição no grau de estabilidade da coluna de água e pelo aumento na profundidade da zona de mistura, fatores ligados à elevação do “clima” de luz subaquático que beneficia, principalmente, as chlorococcales, como Chlorella. Além disso, segundo Happey-Wood (1988) as pequenas algas verdes são caracterizadas por apresentarem “crescimento oportunista” em águas ricas em nutrientes e por se beneficiarem da turbulência, que faz com que elas sejam ressuspensas.

No inverno, foram registradas as maiores densidades fitoplanctônicas, com valores muito superiores aos encontrados no outono. Nas duas lagoas, em todos os horários e profundidades, as maiores biomassas também foram de clorofícea, mais especificamente de Chlorella vulgaris, organismo considerado dominante nesse período. Esta espécie de Chlorococcales também esteve presente em outras épocas de coleta, sendo considerada como abundante; enquanto os outros organismos foram considerados apenas ocasionais ou raros.

Espécies de Chlorella, assim como as demais algas verdes, são consideradas segundo a classificação de MaCarthur e Wilson (1967) como r-estrategistas, ou como cestrategistas pela classificação de Reynolds (1988b), para o fitoplâncton. Organismos com essas estratégias de sobrevivência são caracterizados por: rápidas taxas de crescimento, possuírem elevada razão superfície/volume e alta atividade metabólica. Além disso, o gênero Chlorella é um dos que mais apresentam dispersão pelo ar, haja vista que a colonização de águas paradas por estas algas é extremamente rápida Happey-Wood, (op cit.).

Outra característica relevante dessas algas é a presença de metabolismo mixotrófico, o qual permite que sejam capazes de crescer tanto no escuro - através de assimilação oxidativa de carbono - quanto na presença de luz - por meio da assimilação fotossintética de dióxido de carbono. Isto resulta em vantagens para o organismo, devido à sua alta eficiência energética; pois a energia dissipada é mínima, justamente por causa do acoplamento dos dois sistemas, heterotrófico e autotrófico (OLIVEIRA, 1988).

Reynolds (1996 e 1998) descreveu Chlorella como nanoplâncton eutrófico que apresenta crescimento ótimo em águas ricas em fósforo e carbono inorgânico. Este gênero é bastante utilizado em estudos de cultivo de algas em massa em meio inorgânico, por ser considerado altamente tolerante à poluição; como conseqüência, são freqüentemente encontrados em lagoas de estabilização (PALMER, 1969). 
Muitos estudos realizados em sistemas de lagoas de estabilização citam Chlorella como organismo dominante em pelo menos alguma época amostrada. Há evidências de que o trifosfato de sódio, constituinte do detergente sintético, presente em grande quantidade no esgoto doméstico, estimularia seu crescimento (PALMER, 1980).

Outra justificativa para o predomínio desse gênero nas lagoas analisadas está baseada nos vários estudos que foram realizados com culturas dessa alga, que evidenciaram a produção de um antibiótico constituído de substâncias ativas complexas que apresentam ação contra grande número de bactérias gram positivas e gram negativas (PRATT, ONETO e PRATT, 1945; PRATT, 1948). Essa substância, denominada chlorelina, tem tido largo uso em farmacologia (OLIVEIRA, 1988).

A ação da chlorelina foi descrita por vários autores como substância bactericida, também capaz de inibir o crescimento, a respiração e a fotossíntese de outras algas (PRATT, 1943 e 1948) além de influenciar negativamente o metabolismo de protozoários, moluscos, crustáceos e peixes (PRATT, 1944; RYTHER, 1954). Esse antibiótico pode também apresentar efeito autoinibitório, mas sua produção não é um fenômeno freqüente e só ocorre sob certas condições críticas (SCUTT, 1964). Segundo Pratt (1942), esse inibidor é mais efetivo na presença de altos valores de $\mathrm{pH}(6,5$ - 7,0) do que em valores mais baixos $(3,5-4,0)$. Considerando que o $\mathrm{pH}$ das lagoas estudadas sempre se mostrou acima de 6,0, há possibilidades de que a chlorelina tenha sido produzida, contribuindo assim para a predominância de Chlorella vulgaris. No inverno, período em que essa alga foi dominante, a variação de pH $(6,6$ - 7,4) se enquadrou na faixa de pH citada por Pratt (op cit.) como ótima para maior efetividade do inibidor. No entanto, para confirmação desses indícios seriam necessárias análises que comprovassem a presença da chlorelina no ambiente.

No inverno, a densidade fitoplanctônica da lagoa facultativa 1 esteve associada positivamente à DBO e à condutividade e, negativamente associada à temperatura e ao pH. Na outra lagoa, esta variável apresentou relação diretamente proporcional à temperatura, condutividade, $\mathrm{pH}$ e às concentrações dos nutrientes fósforo e nitrogênio, sendo inversamente proporcional à DBO. Estas correlações são apresentadas no Apêndice B.

O período seguinte, primavera, foi marcado por diminuição nos valores de densidade algal. A máxima encontrada para Chlorophyceae, grupo dominante, foi de 571.196,5 org/mL na primeira lagoa facultativa. Nessa lagoa, a variável apresentou 
correlação positiva com temperatura e sólidos suspensos e negativa com DBO, condutividade, $\mathrm{pH}$ e fósforo. $\mathrm{Na}$ segunda lagoa, a densidade esteve relacionada positivamente apenas às concentrações de nutrientes, e negativamente aos sólidos suspensos, DBO, condutividade e pH (Apêndice B).

Ainda na primavera, as biomassas também estiveram representadas por algas verdes, mas não por Chlorella vulgaris. Na lagoa facultativa 1, Golenkinia radiata contribuiu com os maiores volumes e na segunda lagoa, esta espécie e Chlorella sp se alternaram quanto a maior contribuição ao longo dos horários e profundidades de estudo. Nesse período, assim como nos demais, com exceção do inverno, Chlorella vulgaris passou de dominante a abundante. Por ser um organismo muito pequeno, não teve grande representatividade quanto ao biovolume. Já Chlorella sp e Golenkinia radiata, que foram ocasionais, possuem, no entanto, volumes celulares bem maiores.

No inverno, a espécie Golenkinia radiata esteve ausente nas primeiras coletas e foi considerada rara; na primavera sua abundância aumentou e passou a ocasional e no verão foi considerada comum, com 13,7\% de abundância relativa na primeira lagoa e $18,8 \%$ na segunda.

No período mais quente, como na primavera, na lagoa facultativa 2, Golenkinia radiata e Chlorella sp se alternaram em relação a maior contribuição, tanto nas diferentes profundidades como nos diferentes horários nas duas lagoas. Quanto à densidade, os valores diminuíram e a máxima de Chlorophyceae foi de 421.334,2 org/mL. Essa variável, no verão, na lagoa facultativa 1, foi diretamente proporcional à DBO e inversamente a temperatura, condutividade e pH. Na outra lagoa, a relação foi diretamente proporcional à condutividade e nitrogênio e inversamente à temperatura, pH e DBO (Apêndice B).

Assim como ocorreu no trabalho de Ferreira (1988), realizado em um sistema de lagoas de estabilização localizado em Brasília, DF, não foram detectadas segregações espaciais do fitoplâncton durante os períodos de estudo. Portanto, apesar de ter sido observada estratificação térmica em alguns horários de coleta, principalmente em t1 (por volta das 15:00h), esta não foi duradoura, talvez por se tratar de um sistema raso. Pode-se considerar que o ambiente se manteve homogêneo em relação à comunidade algal ao longo da coluna de água; as diferenças encontradas podem estar relacionadas à variação ao acaso que ocorre durante a coleta de dados, como descrito por Margalef (1983). 
De acordo com Ferreira (op cit.), a distribuição homogênea na coluna de água pode ser provocada pela homogeneização térmica noturna e pela ação dos ventos, que podem resultar em ressuspensão da biomassa algal, comumente observada em lagos tropicais rasos.

Margalef (1983) afirmou que sem a turbulência provocada pelo vento, o sol aqueceria apenas uma camada muito pequena e superficial do ambiente aquático. A partir desta camada, haveria queda brusca de temperatura com valores extremamente baixos nas camadas mais profundas, estabelecendo-se uma barreira térmica na coluna de água. A ação dos ventos ocasiona formação de ondas internas, que provocam movimentos no eixo vertical, influenciando a estabilidade térmica e as variações físicas, químicas e biológicas.

A percentagem de contribuição das classes apresentou variações significativas para Cyanophyceae e Euglenophyceae (Apêndice A). Chlorophyceae apresentou as maiores contribuições em todos os períodos estudados, com valores de $66 \%$ a $85 \%$; e as diatomáceas só estiveram presentes no outono.

A classe Cyanophyceae apresentou variações referentes à contribuição, especialmente entre o verão e as demais épocas, pois naquele período os valores diminuíram muito, provavelmente devido à perturbação causada pelas chuvas.

Os índices de equidade, riqueza e diversidade não apresentaram variação significativa entre os períodos e as lagoas estudadas (Apêndice A). Os valores encontrados para esses índices já eram esperados, porque as lagoas de estabilização são consideradas ecossistemas hipereutróficos. Os valores de diversidade foram menores que 1,0 e os de riqueza não alcançaram 7,0. Para ambos, os maiores valores foram encontrados no verão, época em que a precipitação pode ter atuado como distúrbio, aumentando o número de nichos e, conseqüentemente, a diversidade de espécies.

Segundo Calijuri (1999), na hipótese de Connell de 1978, criada para explicar ambientes com alta diversidade, como recifes de corais e florestas tropicais, as perturbações (ou distúrbios) de níveis intermediários não permitiriam a dominância de uma única espécie e, conseqüentemente impediriam a exclusão competitiva, aumentando a diversidade. 
O inverno foi a época em que os três índices citados permaneceram mais baixos, como conseqüência dos elevados índices de dominância registrados no período - os maiores entre todas as coletas. No verão foram observados os menores valores para este último índice, mostrando ser ele inversamente proporcional aos demais (diversidade, equidade e riqueza).

As concentrações de clorofila $a$ encontradas neste estudo foram muito elevadas, apresentando variações significativas entre as estações de ano, oscilando de 3,2 $\mu \mathrm{g} / \mathrm{L}$ (outono) a 5.139,2 $\mu \mathrm{g} / \mathrm{L}$ (inverno). As maiores diferenças foram registradas entre o inverno e as demais épocas, pois nesse período foram obtidas concentrações três vezes maiores que as dos outros períodos de estudo, coincidindo com as elevadas densidades fitoplanctônicas encontradas na estação fria. Os coeficientes de variação são apresentados no Apêndice A.

Cerqueira (1995) obteve concentrações muito elevadas de clorofila $a$ nas lagoas de estabilização da empresa de frangos ITO, localizada em São Carlos, SP; os valores variaram de 0,63 mg/l a 2,62 mg/L.

Diaz (1990), em seus estudos nictemerais realizados no reservatório de Barra Bonita, encontrou uma distribuição de clorofila $a$ bastante irregular ao longo do ciclo, sem um padrão definido, mas com picos na superfície no horário de 15:30h e menores valores após as 18:30h. Neste estudo, as maiores concentrações também foram observadas nos horários da manhã (9:30 h) e da tarde (15:30 h).

Apesar de ser considerada boa alternativa para o tratamento de esgoto doméstico de pequenas e médias comunidades - devido ao baixo custo operacional e de implementação, à alta remoção de microrganismos patogênicos e à eficiência na remoção de DBO - como constatado neste trabalho, o sistema de lagoas de estabilização pode acarretar sérias alterações nos corpos de água receptores dos seus efluentes. Von Sperling (1996), cita como desvantagem desses sistemas o não atendimento de padrões de lançamento de efluentes mais rigorosos e a necessidade de adoção de um póstratamento para remoção de sólidos suspensos, que são em sua maioria algas. Os dados de sólidos em suspensão observados no presente estudo mostraram, claramente, que em alguns horários e períodos de coleta, as concentrações nas lagoas facultativa foram bem maiores que as dos afluentes, (esgoto “in natura”). Nas lagoas, esse aumento é devido a altas densidades e biomassa de células fitoplanctônicas que proliferam nesses 
ambientes. Trata-se não apenas de entrada de grande quantidade de matéria orgânica no corpo de água receptor, mas de input de organismos exóticos àqueles da flora original

do local. São espécies cuja sobrevivência está relacionada a elevadas cargas orgânicas, ou seja, são específicas de sistemas hipereutróficos.

A Resolução CONAMA 20, de 1986, enquadra os corpos de água do território nacional em classes, com vistas a assegurar os usos preponderantes desses ambientes.

Segundo essa Resolução, o Córrego Três Pontos, receptor do efluente da ETE de Novo Horizonte, deveria se enquadrar na classe 2, cujas águas devem atender:

- ao abastecimento doméstico, após tratamento convencional;

- à proteção das comunidades aquáticas;

- à recreação, como natação, mergulho;

- à irrigação;

- e à aqüicultura.

Para isso, o córrego não pode apresentar:

- $\quad$ DBO superior a $5 \mathrm{mg} / \mathrm{L}$;

- concentração de sólidos suspensos de até 0,01 mg/L;

- pH entre 6 e 9;

- concentração máxima de fosfato total de 0,025 mg/L;

- $\quad$ e de nitrato de $10 \mathrm{mg} / \mathrm{L}$, entre outras exigências.

Entretanto, algumas variáveis medidas no efluente apresentaram valores superiores aos estabelecidos pela Resolução CONAMA 20 para os rios classe 2, notadamente com relação a DBO, nutrientes e sólidos em suspensão.

Com vistas a saber se o tratamento oferecido pela ETE de Novo Horizonte atende às exigências estabelecidas pela Resolução, seriam necessárias análises de amostras do Córrego Três Pontos, para fazer-se uma estimativa da diluição possibilitada pela água do rio nas concentrações oriundas do efluente.

Os sistemas de pós-tratamento - filtros de areia, filtros de pedra, micropeneiras, processos de coagulação e clarificação, flotação e também os mais modernos, como biofiltros aerados - podem melhorar a qualidade do efluente das lagoas, principalmente, no que se refere a remoção de sólidos suspensos, no qual a maior parte são algas. No entanto, a introdução de pós-tratamento implica na elevação de complexidade e de custos do tratamento; o que faz com que sejam aplicáveis somente para lagoas já existentes, não sendo recomendados a novos projetos, pois 
outros tipos de sistemas podem ser mais vantajosos e menos onerosos que a combinação de lagoas facultativas com pós-tratamento (VON SPERLING, 1996). 


\section{CONCLUSÕES}

- A flora das lagoas facultativas da ETE de Novo Horizonte está composta por espécies pertencentes às classes Chlorophyceae, Cyanophyceae, Euglenophyceae e Bacillariophyceae. Chlorophyceae predominou em todas as épocas de estudo, com contribuições superiores a 65\% em todas as coletas. As maiores densidades desta classe foram observadas no inverno, período que apresentou valores muito acima da média dos demais.

- Entre as clorofíceas, a espécie que mais se destacou foi Chlorella vulgaris, caracterizada por apresentar “crescimento oportunista”, assim como as outras Chloroccocales. Esse organismo foi considerado dominante no inverno e abundante nas outras estações do ano; as outras espécies foram apenas comuns, ocasionais ou raras. A capacidade dessa alga em assimilar carbono orgânico na ausência de luz, é uma vantagem para a espécie, pois em lagoas de estabilização a quantidade de luz é restrita a superfície.

- A espécie Aphanocapsa sp foi a que mais contribuiu para a biomassa fitoplanctônica no outono, provavelmente por ter sido esse o período em que as águas se apresentaram mais calmas, sem perturbações causadas pelo vento e pelas chuvas. No inverno, Chlorella vulgaris apresentou as maiores biomassas; apesar de seu tamanho reduzido, os altos valores foram obtidos devido à sua elevada densidade no período. Na primavera e no verão, as maiores biomassas foram de Golenkinia radiata e Chlorella sp, que se alternaram ao longo dos horários e profundidades. As pequenas clorofíceas, normalmente, predominam em ambientes como as lagoas de estabilização, pois apresentam “crescimento oportunista”, beneficiando-se de águas ricas em nutrientes e sob mistura constante.

- Os índices de eqüidade, riqueza e diversidade mostraram-se relativamente baixos; os menores valores foram registrados no inverno, período em que o índice de dominância foi mais alto. Os maiores valores para riqueza e diversidade foram encontrados no verão, coincidindo com os menores 
índices de dominância, devido, provavelmente, à ação das chuvas que podem ter atuado como agente perturbador, propiciando a formação de nichos e, conseqüentemente, aumentando a diversidade.

- As variações nictemerais nesta pesquisa não apresentaram influências na estrutura da comunidade fitoplanctônica. Apesar das alterações de algumas variáveis como oxigênio dissolvido e $\mathrm{pH}$ - dependentes da fotossíntese e da respiração - que diminuíam com o anoitecer, as populações de algas não apresentaram distribuição vertical definida e o ambiente foi considerado homogêneo em relação a essa comunidade. Essa homogeneização pode ter ocorrido em função das constantes misturas provocadas pelo vento, o que é comum em ambientes rasos como o estudado.

- Comparadas as concentrações de algumas variáveis como DBO, sólidos suspensos e nutrientes, registradas no efluente da ETE de Novo Horizonte, com os parâmetros estabelecidos pela Resolução CONAMA 20 de 1986, constatou-se que a eficiência do tratamento não atende o nível de qualidade exigido para um rio classe 2, na qual se enquadra o Córrego Três Pontos. Apesar de ter sido observada redução nos valores de parte dessas variáveis, do afluente para o efluente, ainda há, no corpo receptor, entrada de grande quantidade de matéria orgânica, especialmente de organismos fitoplanctônicos, como mostram os altos valores de densidade e biomassa encontrados no efluente, o que pode acarretar desequilíbrio na comunidade natural daquele ambiente.

- Os sistemas de pós-tratamento - filtros de areia, filtros de pedra, micropeneiras, processos de coagulação e clarificação, flotação e também os mais modernos, como biofiltros aerados - podem ser boas opções para melhorar a qualidade do efluente das lagoas, principalmente, em relação a remoção de sólidos suspensos, no qual a maior parte são algas. No entanto, esses sistemas tornam o tratamento mais complexo e oneroso, sendo aplicável somente para lagoas já existentes. No caso de novos projetos, a 
adoção de outro tipo de sistema talvez apresentasse maiores vantagens, entre elas, menor custo, do que aliar sistemas de lagoas com pós-tratamento. 


\section{REFERÊNCIAS BIBLIOGRÁFICAS}

ALVES, V. R. E.; CAVAlCANTI, C. G. B.; MATTOS, S. P. (1988). Análise comparativa de parâmetros físicos, químicos e biológicos em um período de 24 horas no Lago Paranoá, Brasília - DF, Brasil. Acta Limnol. Brasil., v. 11, p. 199 - 218.

AMERICAN PUBLIC HEALTH ASSOCIATION. (1995). Standart methods for the examination of water and wastewater. $19 \mathrm{t}^{\mathrm{h}}$ ed.,Washington: Byrd Prepess Spingfield.

ANAGNOSTIDIS, K.; KOMAREK, J. (1988). Modern approach to the classification system of cyanophytes: Oscillatoriales. Arch. Hydrobiol. Suppl., v. 80, p. 327 - 472.

BICUDO, C. E. M. et al. (1999). Dinâmica de populações fitoplanctônicas em ambiente eutrofizado: o Lago das Garças, São Paulo. In: HENRY, R. (ed.) Ecologia de Reservatórios: estrutura, função e aspectos sociais. Botucatu: Fapesp/Fundbio. Cap. 15, p. $449-508$.

BRANCO, S. M. (1975). Aspectos biológicos - plâncton. In: CETESB. (1975). Lagoas de estabilização. $2^{\mathrm{a}}$ ed. São Paulo: Cetesb/Ascetesb. Cap. 13, p. 187 - 195.

BRANCO, S. M. (1986). Hidrobiologia aplicada à engenharia sanitária $3^{\mathrm{a}}$ ed. São Paulo: Cetesb/Ascetesb, 616p.

CALIJURI, M. C. (1988). Respostas fisioecológicas da comunidade fitoplanctônica e fatores ecológicos em ecossistemas com diferentes estágios de eutrofização. 293p. Tese (Doutorado) - Escola de Engenharia de São Carlos, Universidade de São Paulo, São Carlos, 1988.

CALIJURI, M. C. (1999). A comunidade fitoplanctônica em um reservatório tropical (barra bonita, sp). 211p. Tese (Livre Docência) - Escola de Engenharia de São Carlos, Universidade de São Paulo, São Carlos, 1999.

CANOVAS, S. et al. (1996). Seasonal development of phytoplankton and zooplankton in a high - rate algal pond. Wat. Set. Tech., v. 33, n. 7, p. 199 - 206. 
CERQUEIRA, B. M. (1995). Caracterização limnológica e produtividade primária em lagoas de estabilização em São Carlos, Estado de São Paulo, Brasil. 121p. Dissertação (Mestrado) - Escola de Engenharia de São Carlos, Universidade de São Paulo, São Carlos, 1995.

COLE, G. A. (1975). Textbook of limnology. St Louis: Mosby Company, 427p.

CONNELL, J. (1978). Diversity in tropical rain forest and coral reefs. Science, v. 199, p. $1304-1310$.

DE LAMONICA-FREIRE, E. M.; BICUDO, C. E. M.; CASTRO, A. A. J. (1992). Ficoflora do Pantanal de Poconé, Estado de Mato Grosso, Brasil, I: Euglenaceae. Rev. Brasil. Biol., v. 52, n. 1, p. 141 - 149.

DIAZ, R A. G. (1990). Flutuações nictemerais dos fatores ecológicos na represa de Barra Bonita - Médio Tiête - SP. Dissertação (Mestrado) - Departamento de Ecologia e Recursos Naturais, Universidade Federal de São Carlos, São Carlos, 1990.

FERREIRA, C. J. A. (1988). Análise da distribuição espaço - temporal da comunidade fitoplanctônica da lagoa de estabilização do Guará I, Brasília, Distrito Federal. 115p. Dissertação (Mestrado) - Universidade de Brasília, Brasília, 1988.

GARCIA De EMILIANI, M. O. (1993). Seasonal sucession of phytoplankton in a lake of the Paraná River floodplain, Argentina. Hydrobiologia, v. 264, p. 101 - 114.

GIANI, A.; LEONARDO, I. M. (1988). Distribuição vertical de algas fitoplanctônicas no reservatório da Pampulha (Belo Horizonte, MG). Acta Limnol. Brasil., v. 11, p. 387 $-404$.

GIANI, A.; FIGUEIREDO, C. C. (1999). Recorrência de padrões sazonais do fitoplâncton num reservatório eutrófico. In: HENRY, R. (ed.) Ecologia de Reservatórios: estrutura, função e aspectos sociais. São Paulo: Fapesp/Fundbio. Cap. 17 , p. $531-550$. 
GOMES, J. L. C. S. (2002). Estudo comparativo entre oito sistemas de lagoas de estabilização da região noroeste do Estado de São Paulo. Dissertação (Mestrado) Escola de Engenharia de São Carlos, Universidade de São Paulo, São Carlos, 2002.

HAPPEY-WOOD, C. M. (1988). Ecology of freshwater planktonic green algae. In: SANDGREEN, C. D. (ed.). Growth and reproductive strategies of freshwater phytoplankton. Cambridge: University Press. Cap. 5, p. 175 - 226.

HARRIS, G. P. (1986). Phytoplankton Ecology: structure, function and fluctuation. London: Chapaman and Hall, 384p.

HENRY, R. (1990). Estrutura espacial e temporal do ambiente físico e químico e análise de alguns processos ecológicos na Represa de Jurumirim (Rio Paranapanema, SP) e na sua bacia hidrográfica. 242p. Tese (Livre - Docência) - Instituto de Biociências de Botucatu, Universidade Estadual Paulista, Botucatu, 1990.

HUBER - PESTALOZZI, G. (1983). Das Phytoplankton des SuBwassers: Systematik and Biologie. , Stuttgart: In Litterisvis, 1044p.

HUSZAR, V. L. M.; SILVA, L. H. S.; ESTVES, F. A. (1990). Estrutura das comunidades fitoplanctônicas de dezoito lagoas da região do Baixo Rio Doce, Linhares, Espirito Santo, Brasil. Rev. Brasil. Biol., v. 50, n. 3, p. 585 - 598.

HUSZAR, V. L. M.; REYNOLDS, C. S. (1997). Phytoplancton periodicity and sequences of dominance in a Amazonian floodplain lake (Lago Batata, Pará, Brazil): responses to gradual environmental change. Hydrobiolia, v. 346, p. 169 - 181.

HUTCHINSON, G. E. (1957). A treatise limnology. Vol. I Geogrphy, physics and chemistry. New York: John Wiley \& Sons. Inc., 1015p.

IBGE (Instituto Brasileiro de Geografia e Estatística): banco de dados (2000). Disponível em http://www.ibge.gov.br>. Acesso em: 16 de maio de 2003. 
KALFF, J. e WATSON, S. (1986). Phytoplankton and its dynamics in two tropical lakes: a tropical and temperate zone comparison. Hydrobiologia, 138, p. 171 - 176.

KAYOMBO, S. et al. (2002). Diurnal cycles of variation of physical - chemical parameters in waste stabilization ponds. Ecological Engineering, v. 18, p. 287 - 291.

KELLNER, E.; PIRES, E. C. (1998). Lagoas de estabilização: Projeto e Operação. Rio de Janeiro, Brasil: ABES, 244p.

KIRK, J. T. O. (1986). Optical limnological - a manifesto. In: DE DECKKER, P.; WILliAMS, W. D. (ed.). Limnology in Australia, Dordrecht, The Netherlands, Austrália: Junk Publishers, p. 33 - 62.

KONIG, A. (1984). Ecophysiological studies on some algae and bacteria of waste stabilization ponds. Tese (Doutorado) - University of Liverpool, Liverpool, 1984.

LORENZEN, C. J. (1967). Determination of chlorophyl and pheo-pigments: spectrophotometric equations. Limnol. Ocenogr., v. 12, p. 343 - 346.

MACARTHUR, R. H.; WILSON, E. O. (1967). The theory of island biogegraphy. New Jersey: Princeton University Press.

MARA, D. D. (1995). Waste stabilization ponds: efluent quality requirements and implications for process design. In: IAWQ - International Specialist Conference Waste Stabilization Ponds: Technology and Aplications, João Pessoa, PB.

MARGALEF, R. (1983). Limnologia. Barcelona: Ediciones Omega, 1010p.

MASSERET, E. et al. (2000). Effects of a waste stabilization lagoon discharge on bacterial and phytoplanktonic communities of a stream. Water Environment Research, v. 72, n. 3, p. $285-294$.

McCOLLOOUGH, J. D.; JACKSON, D. W. (1985). Composition and productivity of the bentic macroinvertebrate community of a subtropical reservoir. Rev. Gesamten Hydrobiol., v. 70, n. 2, p. $221-235$. 
MENDONÇA, S. R. (1990) Lagoas de estabilização e aeradas mecanicamente: novos conceitos. João Pessoa: Ed. S.R. Mendonça, 388p.

. (2000). Sistemas de lagunas de estabilización: como utilizar águas residuales tratadas em sistemas de regadío. Santa Fé de Bogotá: McGraw - Hill Interamericana, 370p.

MENEZES, M. (1990). Estudos taxonômicos sobre o gênero Lepocinclis perty (Euglenaceae) no município do Rio de Janeiro e arredores, Brasil. Ver. Brasil. Biol., v. 50, n. 1, p. $103-113$.

METCALF e EDDY, Inc. (1991). Wastewater engineering - treatment, disposal and reuse. 3 ed.. New York: McGraw - Hill.

OLIVEIRA, H. T. (1988). Utilização da vinhaça como meio de cultura para Chlorella vulgaris (CCAP - 211/11b). Dissertação (Mestrado) - Universidade Federal de São Carlos, São Carlos, 1988.

PALMER, M. C. (1969). A composite rating of algae tolerating organic pollution. $J$. Phycol., v. 5, p. $78-82$. . (1980). Algae and water pollution: the identification, significance and control of algae in water supplies and in polluted water. Castle House, 123p.

PARRA, O.O.; GONZALEZ, M.; DELAROSSA, V. (1982a). Manual Taxonômico del Fitoplancton de águas continentales: con especial referencia al fitoplancton de Chile. I. Cyanophyceae. Concepción: Universidade de Concepción. 69p.

PARRA, O.O.; GONZALEZ, M.; DELAROSSA, V. (1982b). Manual Taxonômico del Fitoplancton de águas continentales: con especial referencia al fitoplancton de Chile. III. Euglenophyceae. Concepción: Universidade de Concepción. 99p. 
PARRA, O.O.; GONZALEZ, M.; DELAROSSA, V. (1983a). Manual Taxonômico del Fitoplancton de águas continentales: con especial referencia al fitoplancton de Chile. I. Chlorophyceae. Concepción: Universidade de Concepción. 363p.

PEARSON, H. W. (1996). the microbiology of waste stabilization ponds and wastewater storage and treatment reservoirs and its impact on design In: Seminário Internacional de Tratamento e Disposição de Esgotos Sanitários: tecnologias e perspectivas para o futuro. Brasília: Companhia de Águas e Esgotos de Brasília, 203p.

PRATT, R. (1942). Studies on Chlorella vulgaris. V. Some properties of the growth inhibitor formed by Chlorella cells. American Journal of Botany, v.. 29, n.. 2, p. 142 148.

(1943). Studies on Chlorella vulgaris. VI. Retardation of photossynthesis by a growth - inhibiting from Chlorella vulgaris. American Journal of Botany, v. 30, n.. 1, p. $32-33$.

(1944). Studies on Chlorella vulgaris. IX. Influence on growth of Chlorella of continuos removal of chlorellin from the culture solution. American Journal of Botany, v. 31, n.. 7, p. $418-421$.

. (1948). Studies on Chlorella vulgaris. XI. Relation between surface tension and accumulation of chlorellin. American Journal of Botany, v. 35, n..9, p. 634 - 637.

PRATT, R; ONETO, J. F.; PRATT, J. (1945). Studies on Chlorella vulgaris. X. Influence of the age of the culture on the accumulation of chlorellin. American Journal of Botany, v. 32, n..7, p. 405 - 408.

RAMIREZ, J. J. (1996). Variações espacial, vertical e nictemeral da estrutura da comunidade fitoplanctônica e variáveis ambientais em quatro dias de amostragens de diferentes épocas do ano no Lago das Garças, São Paulo. 300p. Tese (Doutorado) Instituto de Biociências da Universidade de São Paulo, São Paulo, 1996. 
REYNOLDS C S. (1984). The ecology of freshwater phytoplankton. New York :Cambridge University Press, 384p.

. (1988a). The concept of ecological sucession applied to seasonal peridicity of freshwater phytoplankton. Verh. Internat. Verein. Limnol., v. 23, p. 683 - 691.

(1988b). Functional morphology and the addtive strategies of freshwater phytoplankton. In: SANDGREEN, C. D. (ed.). Growth and reproductive strategies of freshwater phytoplankton. Cambridge: University Press, p 388 - 433.

(1996). The plant life of the pelagic. Verh. Internat. Verein. Limnol., v. 26, p. $97-113$.

(1998). What factors influence the species composition of phytoplankton in lakes of different trophic status? Hydrobiologia, v. 369/370, p. 11 - 26.

RYTHER, J. H. (1954). Inhibitory effects of phytoplankton upon the feeding of Daphinia magna with reference to growth, reproduction and survival. Ecology, v. 35, n. 4, p. $522-533$.

SCUTT, J. E. (1964). Autoinhibitor production by Chlorella vulgaris. American Journal of Botany, v. 51, n..6, p. 581 - 584.

SENNA, P. A. C. (1979). Cyanophyceae da lagoa de estabilização de São Carlos, Estado de São Paulo, Brasil. 116p. Dissertação (Mestrado) - Universidade de São Paulo, São Paulo, 1979.

SHANNON, C. E.; WEAVER, W. (1963). A mathematical theory of comunication. Urbana: University of Ilinois Press, 117p.

SILVA, S. A.; MARA, D. D. (1979). Tratamentos biológicos de águas residuárias lagoas de estabilização. Rio de Janeiro: Alves, 140p.

SIMPSON, E. H. (1949). Measurement of diversity. Nature, v. 163, p. 688. 
SOMMER, U. (Ed.) (1989). Plankton ecology: sucession in plankton communities. New York: Springer - Verlag.

SOUZA, R. C. R. (2000). Dinâmica espaço- temporal da comunidade fitoplanctônica de um reservatório hipereutrófico: Salto Grande (Americana, SP). 172p. Tese (Doutorado) - Escola de Engenharia de São Carlos, Universidade de São Paulo, São Carlos, 2000.

TOLEDO, L. G.; FREITAS, J. S.; FERREIRA, C. J. A. (1988). Variações diurnas de parâmetros limnológicos no Lago Paranoá, Brasília - DF, Brasil. Acta Limnol. Brasil., v. 11 , p. $219-237$.

TRIFONOVA, I. S. (1986). Seasonal and main sucession of lake phytoplankton. Hydrobiological Journal, v. 22, n. 3, p. $19-25$.

. (1988). Oligotrophic - eutrophic sucession of lake phytoplankton. In: ROUND, F. E. (Ed.). Algae and the aquatic environment. Biopress.

UEHARA, . Y. e VIDAL, W. L. (1989). Operação e manutenção de lagoas aneróbias e facultativas. São Paulo: Cetesb.

UTHERMOHL, H. (1958). Zur Vervollkommung der quantitativen PhytoplanktonMethodic. Mitt. int. Verein. Theor. Angew. Limnol.,v. 9, p.1 - 38.

VOLTOLINA, D. et al. (1998). Growth of Scenedesmus sp in artificial wastewater. Bioresource Technology, v.68, p. 265 - 268, 1998.

VON SPERLING, M. (1996a) : Princípios do tratamento biológico de águas residuárias: introdução à qualidade das águas e ao tratamento de esgotos. $2^{\mathrm{a}}$ ed. Belo Horizonte: DESA, Universidade Federal de Minas Gerais, 243p.

VON SPERLING, M. (1996b) : Princípios do tratamento biológico de águas residuárias: lagoas de estabilização. Belo Horizonte: DESA, Universidade Federal de Minas Gerais, 140p. 
VYVERMAN, W. (1991). Freshwater algae from the Spik floodplain (west and east Spik Provinces Papua New guinea). I. Euglenophyta. Belg. Journ. Bot., v. 124, n. 1, p. $33-39$.

WETZEL, R. G.; LIKENS, G. E. (1991). Limnological analysis. $2^{\mathrm{a}}$ ed. New York: Springer - Verlag, 391p.

WRIGLEY, T. J.; TOERIEN, D. F. (1990). Limnological aspects of small sewage ponds. Wat. Res., v. 24, n. 1, p. $83-90$. 


\section{APÊNDICE A - Coeficiente de Variação Estatística}




\section{Temperatura da Água}

- Coeficiente de variação de temperatura entre horários e profundidades de coleta na lagoa facultativa 1 , no outono.

$\begin{array}{rrrrrrrrr}\text { Prof. (m) } & \mathrm{T}\left({ }^{\circ} \mathrm{C}\right) \text {-t0 } & \mathrm{T}\left({ }^{\circ} \mathrm{C}\right) \text {-t1 } & \mathrm{T}\left({ }^{\circ} \mathrm{C}\right)-\mathrm{t} 2 & \mathrm{~T}\left({ }^{\circ} \mathrm{C}\right) \text {-t } 3 & \mathrm{~T}\left({ }^{\circ} \mathrm{C}\right) \text {-t4 } & \text { Média } & \text { Dv P } & \mathrm{CV} \\ 0 & 25,4 & 28,9 & 27,1 & 25,9 & 25,6 & 26,58 & 1,45 & 5,47 \\ 0,1 & 25,6 & 28,7 & 27,1 & 25,9 & 25,6 & 26,58 & 1,34 & 5,03 \\ 0,2 & 25,4 & 27,6 & 27,1 & 25,9 & 25,4 & 26,28 & 1,01 & 3,86 \\ 0,3 & 25,3 & 27,8 & 27,1 & 25,9 & 25,4 & 26,3 & 1,10 & 4,19 \\ 0,4 & 25,3 & 26,7 & 27,1 & 25,9 & 25,4 & 26,08 & 0,79 & 3,05 \\ 0,5 & 25,3 & 26,6 & 27,1 & 25,9 & 25,4 & 26,06 & 0,78 & 2,98 \\ 0,6 & 25,3 & 26 & 27,1 & 25,9 & 25,4 & 25,94 & 0,72 & 2,76 \\ 0,7 & 25,5 & 26 & 27,1 & 25,9 & 25,4 & 25,98 & 0,68 & 2,60 \\ 0,8 & 25,2 & 25,8 & 27,1 & 25,9 & 25,4 & 25,88 & 0,74 & 2,86 \\ 0,9 & 25,2 & 25,7 & 27,1 & 25,9 & 25,4 & 25,86 & 0,74 & 2,88 \\ 1 & 25,2 & 25,7 & 27 & 25,9 & 25,4 & 25,84 & 0,70 & 2,72 \\ 1,1 & 25,2 & 25,6 & 25,7 & 25,9 & 25,3 & 25,54 & 0,29 & 1,13 \\ 1,2 & 25,2 & 25,5 & 25,7 & 25,9 & 25,3 & 25,52 & 0,29 & 1,12 \\ 1,3 & 25,2 & 25,4 & 25,5 & 25,4 & 25,3 & 25,36 & 0,11 & 0,45 \\ 1,4 & 25,2 & 25,4 & 25,4 & 25,3 & 25,3 & 25,32 & 0,08 & 0,33 \\ 1,5 & 25,2 & 25,3 & 25,3 & 25,3 & 25,3 & 25,28 & 0,04 & 0,18 \\ \text { Média } & 25,29 & 26,42 & 26,60 & 25,79 & 25,39 & & & \\ \text { Dv P } & 0,12 & 1,19 & 0,76 & 0,23 & 0,09 & & & \\ \text { CV } & 0,49 & 4,52 & 2,85 & 0,89 & 0,37 & & & \end{array}$

- Coeficiente de variação de temperatura entre horários e profundidades de coleta na lagoa facultativa 2, no outono.

\begin{tabular}{|c|c|c|c|c|c|c|c|c|c|}
\hline Prof. (m) & $\mathrm{T}\left({ }^{\circ} \mathrm{C}\right)$-to & $\mathrm{T}\left({ }^{\circ} \mathrm{C}\right)-\mathrm{t} 1$ & $\mathrm{~T}\left({ }^{\circ} \mathrm{C}\right)-\mathrm{t} 2$ & $\mathrm{~T}\left({ }^{\circ} \mathrm{C}\right)-\mathrm{t} 3$ & $\mathrm{~T}\left({ }^{\circ} \mathrm{C}\right)-\mathrm{t} 4$ & Média & Dv P & & \\
\hline 0 & 25,4 & 31,1 & 27 & 25,5 & 25,6 & 26,9 & & 2,43 & 9,01 \\
\hline 0,1 & 25,5 & 31 & 27 & 25,5 & 25,2 & 26,8 & & 2,43 & 9,05 \\
\hline 0,2 & 25,4 & 29,4 & 27 & 25,5 & 25,2 & 26,5 & & 1,77 & 6,69 \\
\hline 0,3 & 25,4 & 27,1 & 26,6 & 25,5 & 25,2 & 26,0 & & 0,84 & 3,23 \\
\hline 0,4 & 25,4 & 26,7 & 26,4 & 25,5 & 25 & 25,8 & & 0,72 & 2,78 \\
\hline 0,5 & 25,2 & 26,2 & 26,2 & 25,5 & 25 & 25,6 & & 0,56 & 2,18 \\
\hline 0,6 & 25,2 & 26 & 26,1 & 25,5 & 25 & 25,6 & & 0,48 & 1,89 \\
\hline 0,7 & 25,1 & 25,5 & 26 & 25,5 & 25 & 25,4 & & 0,40 & 1,56 \\
\hline 0,8 & 25,1 & 25,2 & 26 & 25,4 & 25 & 25,3 & & 0,40 & 1,57 \\
\hline 0,9 & 25 & 25,2 & 25,7 & 25,4 & 25 & 25,3 & & 0,30 & 1,17 \\
\hline 1 & 25 & 25,2 & 25,6 & 25,2 & 25 & 25,2 & & 0,24 & 0,97 \\
\hline 1,1 & 24,9 & 25 & 25,6 & 25,1 & 24,9 & 25,1 & & 0,29 & 1,16 \\
\hline 1,2 & 24,8 & 24,9 & 25,4 & 25 & 24,9 & 25,0 & & 0,23 & 0,94 \\
\hline 1,3 & 24,8 & & 25,3 & 25 & 24,9 & 25,0 & & 0,22 & 0,86 \\
\hline 1,4 & 24,8 & & 25,1 & 25 & 24,9 & 25,0 & & 0,13 & 0,52 \\
\hline 1,5 & 24,8 & & 25 & 25 & 24,9 & 24,9 & & 0,10 & 0,38 \\
\hline Média & 25,11 & 26,81 & 26,00 & 25,32 & 25,04 & & & & \\
\hline Dv P & 0,25 & 2,24 & 0,67 & 0,22 & 0,18 & & & & \\
\hline $\mathrm{CV}$ & 1,01 & 8,36 & 2,56 & 0,88 & 0,73 & & & & \\
\hline
\end{tabular}


- Coeficiente de variação de temperatura entre horários e profundidades de coleta na lagoa facultativa 1 , no inverno.

\begin{tabular}{|c|c|c|c|c|c|c|c|c|c|}
\hline Prof. (m) & $\mathrm{T}\left({ }^{\circ} \mathrm{C}\right)-\mathrm{t} 0$ & $\mathrm{~T}\left({ }^{\circ} \mathrm{C}\right)-\mathrm{t} 1$ & $\mathrm{~T}\left({ }^{\circ} \mathrm{C}\right)-\mathrm{t} 2$ & $\mathrm{~T}\left({ }^{\circ} \mathrm{C}\right)-\mathrm{t} 3$ & $\mathrm{~T}\left({ }^{\circ} \mathrm{C}\right)-\mathrm{t} 4$ & Média & Dv P & & \\
\hline 0 & 23,1 & 25,6 & 24,2 & 23,4 & 23,6 & 23,98 & & 0,99 & 4,13 \\
\hline 0,1 & 23,1 & 25,5 & 24,2 & 23,5 & 23,5 & 23,96 & & 0,95 & 3,96 \\
\hline 0,2 & 23,1 & 25,6 & 24,2 & 23,5 & 23,4 & 23,96 & & 1,00 & 4,18 \\
\hline 0,3 & 23,1 & 25,4 & 24,2 & 23,5 & 23,2 & 23,88 & & 0,95 & 3,99 \\
\hline 0,4 & 23,1 & 25 & 24,2 & 23,5 & 23,2 & 23,8 & & 0,80 & 3,35 \\
\hline 0,5 & 23,1 & 24,5 & 24,2 & 23,5 & 23,1 & 23,68 & & 0,64 & 2,71 \\
\hline 0,6 & 23,1 & 24,4 & 24,2 & 23,5 & 23,1 & 23,66 & & 0,61 & 2,58 \\
\hline 0,7 & 23,1 & 24,4 & 24,2 & 23,5 & 23,1 & 23,66 & & 0,61 & 2,58 \\
\hline 0,8 & 23,1 & 24,3 & 24,2 & 23,5 & 23,1 & 23,64 & & 0,58 & 2,46 \\
\hline 0,9 & 23,1 & 24,2 & 24,2 & 23,5 & 23,1 & 23,62 & & 0,55 & 2,35 \\
\hline 1 & 23,1 & 24,2 & 24,1 & 23,5 & 23,1 & 23,6 & & 0,53 & 2,24 \\
\hline 1,1 & 23,1 & 24,2 & 24,1 & 23,5 & 23,1 & 23,6 & & 0,53 & 2,24 \\
\hline 1,2 & 23 & 24,1 & 24,1 & 23,5 & 23,1 & 23,56 & & 0,53 & 2,24 \\
\hline 1,3 & 23 & 24 & 24 & 23,5 & 23,1 & 23,52 & & 0,48 & 2,03 \\
\hline 1,4 & 23,1 & 24 & 24 & 23,4 & 23,1 & 23,52 & & 0,45 & 1,93 \\
\hline 1,5 & 23,1 & 24 & 23,6 & 23,3 & 23,1 & 23,42 & & 0,38 & 1,64 \\
\hline Média & 23,09 & 24,59 & 24,12 & 23,48 & 23,19 & & & & \\
\hline Dv P & 0,03 & 0,61 & 0,16 & 0,06 & 0,16 & & & & \\
\hline CV & 0,15 & 2,48 & 0,65 & 0,25 & 0,70 & & & & \\
\hline
\end{tabular}

- Coeficiente de variação de temperatura entre horários e profundidades de coleta na lagoa facultativa 2, no inverno.

\begin{tabular}{|c|c|c|c|c|c|c|c|c|c|}
\hline Prof. (m) & $\mathrm{T}\left({ }^{\circ} \mathrm{C}\right)-\mathrm{t} 0$ & $\mathrm{~T}\left({ }^{\circ} \mathrm{C}\right)-\mathrm{t} 1$ & $\mathrm{~T}\left({ }^{\circ} \mathrm{C}\right)-\mathrm{t} 2$ & $\mathrm{~T}\left({ }^{\circ} \mathrm{C}\right)-\mathrm{t} 3$ & $\mathrm{~T}\left({ }^{\circ} \mathrm{C}\right)-\mathrm{t} 4$ & Média & Dv $P$ & & \\
\hline 0 & 23,1 & 25,3 & 24 & 23,3 & 23,3 & 23,8 & & 0,91 & 3,80 \\
\hline 0,1 & 23,1 & 24,9 & 24 & 23,4 & 23,1 & 23,7 & & 0,76 & 3,23 \\
\hline 0,2 & 23,1 & 24,7 & 24,1 & 23,4 & 23,1 & 23,68 & & 0,70 & 2,96 \\
\hline 0,3 & 23,1 & 25 & 24,1 & 23,4 & 23 & 23,72 & & 0,83 & 3,52 \\
\hline 0,4 & 23,1 & 24,7 & 24,1 & 23,4 & 23 & 23,66 & & 0,72 & 3,06 \\
\hline 0,5 & 23,1 & 24,1 & 24,1 & 23,4 & 23 & 23,54 & & 0,53 & 2,26 \\
\hline 0,6 & 23,1 & 24,1 & 24,1 & 23,4 & 23 & 23,54 & & 0,53 & 2,26 \\
\hline 0,7 & 23,1 & 24 & 24,1 & 23,4 & 23 & 23,52 & & 0,51 & 2,16 \\
\hline 0,8 & 23,1 & 24 & 24,1 & 23,4 & 23 & 23,52 & & 0,51 & 2,16 \\
\hline 0,9 & 23,1 & 24 & 24,1 & 23,4 & 22,9 & 23,5 & & 0,53 & 2,27 \\
\hline 1 & 23,1 & 23,8 & 23,8 & 23,4 & 22,9 & 23,4 & & 0,41 & 1,74 \\
\hline 1,1 & 23,1 & 23,7 & 23,8 & 23,4 & 22,9 & 23,38 & & 0,38 & 1,64 \\
\hline 1,2 & 23,1 & 23,7 & 23,8 & 23,4 & 22,9 & 23,38 & & 0,38 & 1,64 \\
\hline 1,3 & 23,1 & 23,6 & 23,6 & 23,4 & 22,9 & 23,32 & & 0,31 & 1,34 \\
\hline 1,4 & 23,1 & 23,6 & 23,5 & 23,3 & 22,9 & 23,28 & & 0,29 & 1,23 \\
\hline 1,5 & 23,1 & 23,5 & 23,3 & 23,3 & 22,9 & 23,22 & & 0,23 & 0,98 \\
\hline Média & 23,10 & 24,17 & 23,91 & 23,38 & 22,99 & & & & \\
\hline Dv $P$ & 0,00 & 0,57 & 0,26 & 0,04 & 0,11 & & & & \\
\hline $\mathrm{CV}$ & 0,00 & 2,35 & 1,07 & 0,17 & 0,47 & & & & \\
\hline
\end{tabular}


- Coeficiente de variação de temperatura entre horários e profundidades de coleta na lagoa facultativa 1 , na primavera.

\begin{tabular}{|c|c|c|c|c|c|c|c|c|c|}
\hline Prof. (m) & $\mathrm{T}\left({ }^{\circ} \mathrm{C}\right)-\mathrm{to}$ & $\mathrm{T}\left({ }^{\circ} \mathrm{C}\right)-\mathrm{t} 1$ & $\mathrm{~T}\left({ }^{\circ} \mathrm{C}\right)-\mathrm{t} 2$ & $\mathrm{~T}\left({ }^{\circ} \mathrm{C}\right)-\mathrm{t} 3$ & $\mathrm{~T}\left({ }^{\circ} \mathrm{C}\right)-\mathrm{t} 4$ & Média & Dv P & & \\
\hline 0 & 25,4 & 26 & 25,4 & 24,4 & 23,9 & 25,02 & & 0,85 & 3,40 \\
\hline 0,1 & 25,4 & 26 & 25,4 & 24,4 & 23,9 & 25,02 & & 0,85 & 3,40 \\
\hline 0,2 & 25,4 & 26 & 25,4 & 24,4 & 23,9 & 25,02 & & 0,85 & 3,40 \\
\hline 0,3 & 25,4 & 26 & 25,4 & 24,4 & 23,9 & 25,02 & & 0,85 & 3,40 \\
\hline 0,4 & 25,4 & 26 & 25,4 & 24,4 & 23,9 & 25,02 & & 0,85 & 3,40 \\
\hline 0,5 & 25,3 & 26 & 25,4 & 24,5 & 23,9 & 25,02 & & 0,82 & 3,29 \\
\hline 0,6 & 25,4 & 26 & 25,4 & 24,5 & 23,9 & 25,04 & & 0,83 & 3,32 \\
\hline 0,7 & 25,3 & 26 & 25,4 & 24,5 & 23,9 & 25,02 & & 0,82 & 3,29 \\
\hline 0,8 & 25,3 & 26 & 25,4 & 24,5 & 23,9 & 25,02 & & 0,82 & 3,29 \\
\hline 0,9 & 25,3 & 25,9 & 25,4 & 24,4 & 23,9 & 24,98 & & 0,81 & 3,24 \\
\hline 1 & 25,3 & 25,7 & 25,4 & 24,4 & 23,9 & 24,94 & & 0,76 & 3,04 \\
\hline 1,1 & 25,3 & 25,8 & 25,4 & 24,4 & 23,9 & 24,96 & & 0,78 & 3,14 \\
\hline 1,2 & 25,3 & 25,7 & 25,4 & 24,4 & 23,9 & 24,94 & & 0,76 & 3,04 \\
\hline 1,3 & 25,3 & 25,4 & 25,4 & 24,4 & 23,9 & 24,88 & & 0,69 & 2,78 \\
\hline 1,4 & 25,3 & 25,4 & 25,4 & 24,4 & 23,9 & 24,88 & & 0,69 & 2,78 \\
\hline 1,5 & 25,3 & 25,3 & 25,4 & 24,4 & 23,9 & 24,86 & & 0,67 & 2,7 \\
\hline Média & 25,34 & 25,83 & 25,40 & 24,43 & 23,90 & & & & \\
\hline Dv P & 0,05 & 0,25 & 0,00 & 0,04 & 0,00 & & & & \\
\hline $\mathrm{CV}$ & 0,20 & 0,97 & 0,00 & 0,18 & 0,00 & & & & \\
\hline
\end{tabular}

- Coeficiente de variação de temperatura entre horários e profundidades de coleta na lagoa facultativa 2, na primavera.

\begin{tabular}{|c|c|c|c|c|c|c|c|c|c|}
\hline Prof. (m) & $\mathrm{T}\left({ }^{\circ} \mathrm{C}\right)$-to & $\mathrm{T}\left({ }^{\circ} \mathrm{C}\right)-\mathrm{t} 1$ & $\mathrm{~T}\left({ }^{\circ} \mathrm{C}\right)-\mathrm{t} 2$ & $\mathrm{~T}\left({ }^{\circ} \mathrm{C}\right)-\mathrm{t} 3$ & $\mathrm{~T}\left({ }^{\circ} \mathrm{C}\right)-\mathrm{t} 4$ & Média & Dv P & $\mathrm{CV}$ & \\
\hline 0 & 25,4 & 26,2 & 25,2 & 24,3 & 23,8 & 24,98 & & 0,94 & 3,78 \\
\hline 0,1 & 25,4 & 26,2 & 25,2 & 24,3 & 23,7 & 24,96 & & 0,98 & 3,91 \\
\hline 0,2 & 25,3 & 26,1 & 25,2 & 24,3 & 23,8 & 24,94 & & 0,90 & 3,62 \\
\hline 0,3 & 25,3 & 26,2 & 25,2 & 24,3 & 23,7 & 24,94 & & 0,97 & 3,87 \\
\hline 0,4 & 25,3 & 26,1 & 25,2 & 24,3 & 23,7 & 24,92 & & 0,93 & 3,75 \\
\hline 0,5 & 25,3 & 26,1 & 25,2 & 24,3 & 23,7 & 24,92 & & 0,93 & 3,75 \\
\hline 0,6 & 25,3 & 25,8 & 25,2 & 24,3 & 23,7 & 24,86 & & 0,84 & 3,40 \\
\hline 0,7 & 25,3 & 25,8 & 25,2 & 24,3 & 23,7 & 24,86 & & 0,84 & 3,40 \\
\hline 0,8 & 25,3 & 25,6 & 25,2 & 24,3 & 23,7 & 24,82 & & 0,79 & 3,19 \\
\hline 0,9 & 25,2 & 25,5 & 25,2 & 24,3 & 23,7 & 24,78 & & 0,75 & 3,04 \\
\hline 1 & 25,2 & 25,4 & 25,2 & 24,3 & 23,7 & 24,76 & & 0,73 & 2,95 \\
\hline 1,1 & 25,2 & 25,4 & 25,3 & 24,3 & 23,7 & 24,78 & & 0,75 & 3,01 \\
\hline 1,2 & 25,1 & 25,4 & 25,3 & 24,3 & 23,6 & 24,74 & & 0,77 & 3,11 \\
\hline 1,3 & 25,1 & 25,3 & 25,3 & 24,3 & 23,6 & 24,72 & & 0,75 & 3,03 \\
\hline 1,4 & 25 & 25,3 & 25,3 & 24,3 & 23,6 & 24,7 & & 0,74 & 2,99 \\
\hline 1,5 & 25 & 25,2 & 25,3 & 24,3 & 23,6 & 24,68 & & 0,72 & 2,91 \\
\hline Média & 25,23 & 25,73 & 25,23 & 24,30 & 23,69 & & & & \\
\hline Dv $P$ & 0,12 & 0,38 & 0,05 & 0,00 & 0,06 & & & & \\
\hline $\mathrm{CV}$ & 0,50 & 1,46 & 0,19 & 0,00 & 0,26 & & & & \\
\hline
\end{tabular}


- Coeficiente de variação de temperatura entre horários e profundidades de coleta na lagoa facultativa 1 , no verão.

\begin{tabular}{|c|c|c|c|c|c|c|c|c|c|}
\hline Prof. (m) & $\mathrm{T}\left({ }^{\circ} \mathrm{C}\right)-\mathrm{t} 0$ & $\mathrm{~T}\left({ }^{\circ} \mathrm{C}\right)-\mathrm{t} 1$ & $\mathrm{~T}\left({ }^{\circ} \mathrm{C}\right)-\mathrm{t} 2$ & $\mathrm{~T}\left({ }^{\circ} \mathrm{C}\right)-\mathrm{t} 3$ & $\mathrm{~T}\left({ }^{\circ} \mathrm{C}\right)-\mathrm{t} 4$ & Média & Dv $P$ & & \\
\hline 0 & 31,5 & 36,2 & 33,1 & 30,6 & 29,9 & 32,26 & & 2,51 & 7,77 \\
\hline 0,1 & 31,6 & 35,7 & 32,8 & 30,6 & 29,9 & 32,12 & & 2,28 & 7,10 \\
\hline 0,2 & 30,8 & 33,8 & 32,4 & 30,7 & 29,9 & 31,52 & & 1,56 & 4,96 \\
\hline 0,3 & 29,7 & 33,7 & 31,5 & 30,7 & 29,9 & 31,1 & & 1,62 & 5,20 \\
\hline 0,4 & 29,7 & 32,9 & 31,2 & 30,7 & 29,8 & 30,86 & & 1,30 & 4,22 \\
\hline 0,5 & 29,7 & 31,3 & 31,8 & 30,7 & 29,8 & 30,66 & & 0,92 & 2,99 \\
\hline 0,6 & 29,6 & 30,9 & 30,9 & 30,6 & 29,7 & 30,34 & & 0,64 & 2,12 \\
\hline 0,7 & 29,6 & 30,2 & 30,5 & 30,6 & 29,7 & 30,12 & & 0,45 & 1,51 \\
\hline 0,8 & 29,6 & 29,7 & 30,3 & 30,4 & 29,7 & 29,94 & & 0,38 & 1,26 \\
\hline 0,9 & 29,6 & 29,6 & 29,9 & 30,1 & 29,6 & 29,76 & & 0,23 & 0,77 \\
\hline 1 & 29,6 & 29,6 & 29,7 & 29,8 & 29,5 & 29,64 & & 0,11 & 0,38 \\
\hline 1,1 & 29,2 & 29,5 & 29,6 & 29,5 & 29,2 & 29,4 & & 0,19 & 0,64 \\
\hline 1,2 & 28,5 & 29,5 & 29,4 & 28,9 & 28,4 & 28,94 & & 0,50 & 1,74 \\
\hline 1,3 & 28,5 & 29,4 & 29,2 & 28,9 & 28,4 & 28,88 & & 0,43 & 1,50 \\
\hline 1,4 & 28,2 & 29,3 & 28,9 & 28,7 & 28,4 & 28,7 & & 0,43 & 1,50 \\
\hline 1,5 & 27,7 & 29 & 28,7 & 28,6 & 28,2 & 28,44 & & 0,50 & 1,77 \\
\hline Média & 29,57 & 31,27 & 30,62 & 30,01 & 29,38 & & & & \\
\hline Dv P & 1,07 & 2,41 & 1,40 & 0,81 & 0,64 & & & & \\
\hline CV & 3,62 & 7,70 & 4,57 & 2,71 & 2,17 & & & & \\
\hline
\end{tabular}

- Coeficiente de variação de temperatura entre horários e profundidades de coleta na lagoa facultativa 2 , no verão.

\begin{tabular}{|c|c|c|c|c|c|c|c|c|c|}
\hline Prof. (m) & $\mathrm{T}\left({ }^{\circ} \mathrm{C}\right)-\mathrm{t} 0$ & $\mathrm{~T}\left({ }^{\circ} \mathrm{C}\right)-\mathrm{t} 1$ & $\mathrm{~T}\left({ }^{\circ} \mathrm{C}\right)-\mathrm{t} 2$ & $\mathrm{~T}\left({ }^{\circ} \mathrm{C}\right)-\mathrm{t} 3$ & $\mathrm{~T}\left({ }^{\circ} \mathrm{C}\right)-\mathrm{t} 4$ & Média & Dv P & & \\
\hline 0 & 33,9 & 38,8 & 33,8 & 30,8 & 30 & 33,46 & & 3,46 & 10,3 \\
\hline 0,1 & 34,3 & 37,8 & 33,8 & 30,8 & 30 & 33,34 & & 3,11 & 9,3 \\
\hline 0,2 & 30 & 33,3 & 33,8 & 30,8 & 29,9 & 31,56 & & 1,86 & 5,9 \\
\hline 0,3 & 30 & 32,5 & 33,5 & 30,7 & 29,9 & 31,32 & & 1,60 & 5,1 \\
\hline 0,4 & 29,9 & 31,8 & 33 & 30,8 & 29,8 & 31,06 & & 1,35 & 4,4 \\
\hline 0,5 & 29,9 & 30,8 & 30,6 & 30,8 & 29,8 & 30,38 & & 0,49 & 1,6 \\
\hline 0,6 & 29,8 & 30,3 & 30,5 & 30,7 & 29,8 & 30,22 & & 0,41 & 1,4 \\
\hline 0,7 & 29,8 & 30,1 & 30,4 & 30,5 & 29,8 & 30,12 & & 0,33 & 1,1 \\
\hline 0,8 & 29,8 & 29,9 & 30,2 & 30,3 & 29,8 & 30 & & 0,23 & 0,8 \\
\hline 0,9 & 29,7 & 29,8 & 30 & 30,1 & 29,8 & 29,88 & & 0,16 & 0,5 \\
\hline 1 & 29,7 & 29,7 & 29,9 & 30 & 29,8 & 29,82 & & 0,13 & 0,4 \\
\hline 1,1 & 29,6 & 29,7 & 29,9 & 29,7 & 29,7 & 29,72 & & 0,11 & 0,4 \\
\hline 1,2 & 29,5 & 29,7 & 29,8 & 29,6 & 29,6 & 29,64 & & 0,11 & 0,4 \\
\hline 1,3 & 29,2 & 29,6 & 29,7 & 29,3 & 29,3 & 29,42 & & 0,22 & 0,7 \\
\hline 1,4 & 28,9 & 29,4 & 29,5 & 28,9 & 28,9 & 29,12 & & 0,30 & 1,0 \\
\hline 1,5 & 28,3 & 29 & 29 & 28,7 & 28,9 & 28,78 & & 0,29 & 1, \\
\hline Média & 30,14 & 31,39 & 31,09 & 30,16 & 29,68 & & & & \\
\hline Dv $\mathrm{P}$ & 1,61 & 2,95 & 1,79 & 0,72 & 0,34 & & & & \\
\hline $\mathrm{CV}$ & 5,34 & 9,40 & 5,75 & 2,39 & 1,16 & & & & \\
\hline
\end{tabular}


- Coeficiente de variação de temperatura entre os períodos estudados na lagoa facultativa 1.

$\begin{array}{rrrrrrr}\text { Média/out. } & \text { Média/inv. Média/prim. } & \text { Média/ver. } & \text { Média } & \text { Dv P } & \text { CV } \\ 26,58 & 23,98 & 25,02 & 32,26 & 26,96 & 3,69 & 13,69 \\ 26,58 & 23,96 & 25,02 & 32,12 & 26,92 & 3,63 & 13,48 \\ 26,28 & 23,96 & 25,02 & 31,52 & 26,695 & 3,35 & 12,56 \\ 26,3 & 23,88 & 25,02 & 31,1 & 26,575 & 3,17 & 11,95 \\ 26,08 & 23,8 & 25,02 & 30,86 & 26,44 & 3,09 & 11,69 \\ 26,06 & 23,68 & 25,02 & 30,66 & 26,355 & 3,03 & 11,50 \\ 25,94 & 23,66 & 25,04 & 30,34 & 26,245 & 2,89 & 11,00 \\ 25,98 & 23,66 & 25,02 & 30,12 & 26,195 & 2,78 & 10,63 \\ 25,88 & 23,64 & 25,02 & 29,94 & 26,12 & 2,71 & 10,37 \\ 25,86 & 23,62 & 24,98 & 29,76 & 26,055 & 2,64 & 10,12 \\ 25,84 & 23,6 & 24,94 & 29,64 & 26,005 & 2,59 & 9,97 \\ 25,54 & 23,6 & 24,96 & 29,4 & 25,875 & 2,49 & 9,61 \\ 25,52 & 23,56 & 24,94 & 28,94 & 25,74 & 2,29 & 8,88 \\ 25,36 & 23,52 & 24,88 & 28,88 & 25,66 & 2,28 & 8,90 \\ 25,32 & 23,52 & 24,88 & 28,7 & 25,605 & 2,20 & 8,60 \\ 25,28 & 23,42 & 24,86 & 28,44 & 25,5 & 2,12 & 8,30\end{array}$

- Coeficiente de variação de temperatura entre os períodos estudados na lagoa facultativa 2.

$\begin{array}{rrrrrrr}\text { Média/out. } & \text { Média/inv. Média/prim. } & \text { Média/ver. } & \text { Média } & \text { Dv P } & \text { CV } \\ 26,9 & 23,8 & 24,98 & 33,46 & 27,3 & 4,31 & 15,8 \\ 26,8 & 23,7 & 24,96 & 33,34 & 27,2 & 4,29 & 15,7 \\ 26,5 & 23,68 & 24,94 & 31,56 & 26,7 & 3,46 & 13,0 \\ 26,0 & 23,72 & 24,94 & 31,32 & 26,5 & 3,35 & 12,7 \\ 25,8 & 23,66 & 24,92 & 31,06 & 26,4 & 3,25 & 12,3 \\ 25,6 & 23,54 & 24,92 & 30,38 & 26,1 & 2,97 & 11,4 \\ 25,6 & 23,54 & 24,86 & 30,22 & 26,0 & 2,91 & 11,2 \\ 25,4 & 23,52 & 24,86 & 30,12 & 26,0 & 2,87 & 11,1 \\ 25,3 & 23,52 & 24,82 & 30 & 25,9 & 2,83 & 10,9 \\ 25,3 & 23,5 & 24,78 & 29,88 & 25,9 & 2,78 & 10,8 \\ 25,2 & 23,4 & 24,76 & 29,82 & 25,8 & 2,79 & 10,8 \\ 25,1 & 23,38 & 24,78 & 29,72 & 25,7 & 2,75 & 10,7 \\ 25,0 & 23,38 & 24,74 & 29,64 & 25,7 & 2,73 & 10,6 \\ 25,0 & 23,32 & 24,72 & 29,42 & 25,6 & 2,64 & 10,3 \\ 25,0 & 23,28 & 24,7 & 29,12 & 25,5 & 2,51 & 9,9 \\ 24,9 & 23,22 & 24,68 & 28,78 & 25,4 & 2,37 & 9,3\end{array}$


- Coeficiente de variação de temperatura entre o inverno e o verão.

$\begin{array}{rrr}\text { Média } & \text { Dv P } & \text { CV } \\ 28,63 & 6,83 & 23,9 \\ 28,52 & 6,82 & 23,9 \\ 27,62 & 5,57 & 20,2 \\ 27,52 & 5,37 & 19,5 \\ 27,36 & 5,23 & 19,1 \\ 26,96 & 4,84 & 17,9 \\ 26,88 & 4,72 & 17,6 \\ 26,82 & 4,67 & 17,4 \\ 26,76 & 4,58 & 17,1 \\ 26,69 & 4,51 & 16,9 \\ 26,61 & 4,54 & 17,1 \\ 26,55 & 4,48 & 16,9 \\ 26,51 & 4,43 & 16,7 \\ 26,37 & 4,31 & 16,4 \\ 26,2 & 4,13 & 15,8 \\ 26 & 3,93 & 15,1\end{array}$

\section{DBO}

- Coeficiente de variação da DBO entre os períodos estudados.

\begin{tabular}{|c|c|c|c|c|c|c|c|}
\hline & Média/out. & édia/inv. I & lia/prim. & dia/ver. & Média & Dv $P$ & CV \\
\hline E1 & 999,50 & 497,50 & 748,50 & 623,00 & 717,13 & 214,33 & 29,89 \\
\hline E2 & 372,50 & 146,50 & 259,50 & 203,00 & 245,38 & 96,49 & 39,32 \\
\hline E3S & 253,50 & 132,00 & 192,75 & 162,38 & 185,16 & 51,88 & 28,02 \\
\hline E4S & 277,50 & 130,50 & 204,00 & 167,25 & 194,81 & 62,76 & 32,22 \\
\hline E5 & 266,50 & 153,50 & 210,00 & 181,75 & 202,94 & 48,25 & 23,77 \\
\hline
\end{tabular}

\section{- Coeficiente de variação da concentração de DBO entre o afluente e o efluente do sistema.}

Outono

$\begin{array}{rrr}\text { Média E1/E5 } & \text { Dv P } & \text { CV } \\ 633,00 & 518,31 & 81,88\end{array}$

Inverno

$\begin{array}{rrr}\text { Média E1/E5 } & \text { Dv P } & \text { CV } \\ 325,50 & 243,24 & 74,73\end{array}$

Primavera

$\begin{array}{rrr}\text { Média E1/E5 } & \text { Dv P } & \text { CV } \\ 377,25 & 162,99 & 43,20\end{array}$


Verão

$\begin{array}{rrr}\text { Média E1/E5 } & \text { Dv P } & \text { CV } \\ 439,25 & 455,02 & 103,59\end{array}$

\section{Sólidos Suspensos}

- Coeficiente de variação da concentração de sólidos suspensos entre o afluente e o efluente do sistema.

Outono

$\begin{array}{rrr}\text { Média E1/E5 } & \text { Dv P } & \text { CV } \\ 186,75 & 114,20 & 61,15\end{array}$

Inverno

$\begin{array}{rrr}\text { Média E1/E5 } & \text { Dv P } & \text { CV } \\ 287,50 & 109,60 & 38,12\end{array}$

Primavera

$\begin{array}{rrr}\text { Média E1/E5 } & \text { Dv P } & \text { CV } \\ 219,25 & 150,97 & 68,86\end{array}$

Verão

$\begin{array}{rrr}\text { Média E1/E5 } & \text { Dv P } & \text { CV } \\ 168,50 & 171,83 & 101,97\end{array}$

\section{Nutrientes}

- Coeficiente de variação da concentração de fósforo total entre os períodos estudados.

$\begin{array}{lrrrrrrr} & \text { Média/out. } & \text { Média/inv. Média/prim. } & \text { Média/ver. } & \text { Média } & \text { Dv P } & \text { CV } \\ \text { E3S } & 16,98 & 16,32 & 18,28 & 17,44 & 17,26 & 0,71 & 4,13 \\ \text { E3M } & 16,8 & 14,2 & 18,5 & 15,28 & 16,20 & 1,62 & 10,00 \\ \text { E3F } & 16,76 & 15,36 & 18,58 & 15,36 & 16,52 & 1,32 & 8,01 \\ \text { E4S } & 17,12 & 16,02 & 18,56 & 13,58 & 16,32 & 1,82 & 11,15 \\ \text { E4M } & 17,22 & 15,22 & 18,88 & 13,16 & 16,12 & 2,14 & 13,30 \\ \text { E4F } & 17,18 & 15,6 & 18,96 & 13,76 & 16,38 & 1,92 & 11,73\end{array}$

- Coeficiente de variação da concentração de nitrogênio total entre os períodos estudados.

\begin{tabular}{|c|c|c|c|c|c|c|c|}
\hline & Média/out. & lia/inv. & prim. & a/ver. & Média & Dv $P$ & $\mathrm{CV}$ \\
\hline E3S & 49,78 & 58,60 & 44,8 & 44,2 & 49,35 & 5,77 & 11,68 \\
\hline E3M & 51,42 & 57,00 & 47,4 & 38,6 & 48,61 & 6,71 & 13,80 \\
\hline E3F & 49,22 & 58,80 & 46 & 38,6 & 48,16 & 7,25 & 15,06 \\
\hline E4S & 58,06 & 53,80 & 47 & 27,2 & 46,52 & 11,83 & 25,43 \\
\hline E4M & 49,06 & 49,60 & 44,4 & 28,4 & 42,87 & 8,59 & 20,05 \\
\hline $\mathrm{E} 4 \mathrm{~F}$ & 52,64 & 51,60 & 46,4 & 32,2 & 45,71 & 8,15 & $17, \varepsilon$ \\
\hline
\end{tabular}




\section{Dens.idade Fitoplanctônica}

- Coeficiente de variação da Dens.idade entre os períodos estudados.

\begin{tabular}{|c|c|c|c|c|c|c|c|}
\hline & Média/out. & Média/inv. & Média/prim. & Média/ver. & Média & Dv $P$ & $C V$ \\
\hline E3s & 16359,4 & 552770,8 & 405119,6 & 152114,3 & 281591,1 & 242150,0 & 85,99 \\
\hline $3 \mathrm{~N}$ & 21744,6 & 561123,8 & 380797,7 & 142655,8 & 276580,5 & 241318,1 & 87,25 \\
\hline 3 & 18529,1 & 612224,4 & 372199 & 285557,3 & 322127,5 & 245066,5 & 76,08 \\
\hline E4S & 26470,8 & 637529 & 300216 & 111516,4 & 268933,1 & 271053,2 & 100,79 \\
\hline $4 \mathrm{M}$ & 12101,6 & 548348,7 & 256485,7 & 136165,9 & 238275,4 & 229534,3 & 96,33 \\
\hline 4 & 14317,6 & 491106,2 & 293091,4 & 163988,7 & 240626,0 & 202140,0 & 84,01 \\
\hline
\end{tabular}

- Coeficiente de variação da Dens.idade entre cada um dos períodos estudados.

$\begin{array}{crrr} & \text { Média } & \text { Dv P } & \text { CV } \\ \text { Out./Inv. } & 292718,8 & 388152,1 & 132,60 \\ \text { Out./Prim. } & 176452,7 & 223727,0 & 126,79 \\ \text { Out./Ver. } & 91793,5 & 104000,7 & 113,30 \\ \text { Inv./Prim. } & 450917,7 & 164425,1 & 36,46 \\ \text { Inv./Ver. } & 366258,4 & 284151,4 & 77,58 \\ \text { Prim./Ver. } & 249992,3 & 119726,2 & 47,89\end{array}$

\section{* Percentagem de Contribuição das Classes Fitoplanctônicas}

- Coeficiente de variação da percentagem de contribuição das claSSes entre os períodos estudados na lagoa facultativa 1.

\begin{tabular}{|c|c|c|c|c|c|c|c|}
\hline & \multicolumn{4}{|c|}{ Média/out. Média/inv. Média/prim. Média/ver. } & Média & Dv $P$ & $\mathrm{CV}$ \\
\hline ChloropHyceae & 77,1 & 66,5 & 72,7 & 84,7 & 75,25 & 7,65 & 10,17 \\
\hline CyanopHyceae & 20,3 & 29,9 & 26,2 & 10,8 & 21,80 & 8,33 & 38,22 \\
\hline EuglenopHyceae & 2,7 & 7,8 & 1,1 & 4,5 & 4,03 & 2,87 & 71,42 \\
\hline BacillariopHyceae & 0,6 & 0 & 0 & 0 & 0,15 & 0,30 & 200,00 \\
\hline
\end{tabular}

- Coeficiente de variação da percentagem de contribuição das claSSes entre os períodos estudados na lagoa facultativa 2.

$\begin{array}{lrrrrrrr} & \text { Média/out. Média/inv. Média/prim. Média/ver. } & \text { Média } & \text { Dv P } & \text { CV } \\ \text { ChloropHyceae } & 75,1 & 79 & 73,4 & 83,7 & 77,80 & 4,58 & 5,89 \\ \text { CyanopHyceae } & 20,9 & 20,8 & 25,9 & 15 & 20,65 & 4,46 & 21,58 \\ \text { EuglenopHyceae } & 4,9 & 0,2 & 0,8 & 1,2 & 1,78 & 2,12 & 119,63 \\ \text { BacillariopHyceae } & 0,2 & 0 & 0 & 0 & 0,05 & 0,10 & 200,00\end{array}$




\section{Índices de diversidade, equidade, riqueza e dominância}

- Coeficiente de variação dos índices de diversidade entre os períodos e as lagoas estudadas.

$\begin{array}{crrrrrrr} & \text { Média/out. } & \text { Média/inv. Média/prim. } & \text { Média/ver. } & \text { Média } & \text { Dv P } & \text { CV } \\ \text { LF 1 } & 0,8 & 0,566 & 0,717 & 0,834 & 0,729 & 0,119 & 16,37 \\ \text { LF 2 } & 0,815 & 0,461 & 0,641 & 0,838 & 0,689 & 0,175 & 25,48 \\ \text { Média } & 0,808 & 0,514 & 0,679 & 0,836 & & & \\ \text { Dv P } & 0,011 & 0,074 & 0,054 & 0,003 & & & \\ \text { CV } & 1,31 & 14,46 & 7,91 & 0,34 & & & \end{array}$

- Coeficiente de variação dos índices de equidade entre os períodos e as lagoas estudadas.

$\begin{array}{crrrrrrr} & \text { Média/out. } & \text { Média/inv. Média/prim. } & \text { Média/ver. } & \text { Média } & \text { Dv P } & \text { CV } \\ \text { LF } 1 & 0,680 & 0,47 & 0,583 & 0,631 & 0,591 & 0,090 & 15,21 \\ \text { LF 2 } & 0,662 & 0,392 & 0,501 & 0,634 & 0,547 & 0,125 & 22,86 \\ \text { Média } & 0,671 & 0,431 & 0,542 & 0,633 & & & \\ \text { Dv P } & 0,013 & 0,055 & 0,058 & 0,002 & & & \\ \text { CV } & 1,91 & 12,80 & 10,70 & 0,34 & & & \end{array}$

- Coeficiente de variação dos índices de riqueza entre os períodos e as lagoas estudadas.

$\begin{array}{crrrrrrr} & \text { Média/out. } & \text { Média/inv. Média/prim. } & \text { Média/ver. } & \text { Média } & \text { Dv P } & \text { CV } \\ \text { LF 1 } & 4,76 & 4,43 & 5,07 & 6,53 & 5,198 & 0,926 & 17,82 \\ \text { LF 2 } & 5,46 & 4,23 & 5,92 & 6,34 & 5,488 & 0,912 & 16,62 \\ \text { Média } & 5,11 & 4,33 & 5,495 & 6,435 & & & \\ \text { Dv P } & 0,495 & 0,141 & 0,601 & 0,134 & & & \\ \text { CV } & 9,69 & 3,27 & 10,94 & 2,09 & & & \end{array}$

- Coeficiente de variação dos índices de dominância entre os períodos e as lagoas estudadas.

$\begin{array}{crrrrrrr} & \text { Média/out. } & \text { Média/inv. Média/prim. } & \text { Média/ver. } & \text { Média } & \text { Dv P } & \text { CV } \\ \text { LF 1 } & 0,204 & 0,404 & 0,292 & 0,216 & 0,279 & 0,092 & 32,97 \\ \text { LF 2 } & 0,207 & 0,492 & 0,343 & 0,191 & 0,308 & 0,140 & 45,48 \\ \text { Média } & 0,206 & 0,448 & 0,318 & 0,204 & & & \\ \text { Dv P } & 0,002 & 0,062 & 0,036 & 0,018 & & & \\ \text { CV } & 1,03 & 13,89 & 11,36 & 8,69 & & & \end{array}$


- Coeficiente de variação dos índices de dominância entre cada um dos períodos estudados.

$\begin{array}{crrr} & \text { Média } & \text { Dv P } & \text { CV } \\ \text { Out./Inv. } & 0,33 & 0,17 & 52,48 \\ \text { Out./Prim. } & 0,26 & 0,14 & 54,18 \\ \text { Out./Ver. } & 0,20 & 0,08 & 38,73 \\ \text { Inv./Prim. } & 0,38 & 0,09 & 24,11 \\ \text { Inv./Ver. } & 0,33 & 0,17 & 53,07 \\ \text { Prim./Ver. } & 0,26 & 0,08 & 30,94\end{array}$

\section{Clorofila $a$}

- Coeficiente de variação da concentração de clorofila $a$ entre os períodos estudados, na lagoa facultativa 1.

$\begin{array}{crrrrrrr} & \text { Média/out. } & \text { Média/inv. Média/prim. } & \text { Média/ver. } & \text { Média } & \text { Dv P } & \text { CV } \\ \text { Superf. } & 233,93 & 3715,78 & 967,12 & 1447,25 & 1591,02 & 1501,80 & 94,39 \\ \text { Meio } & 211,78 & 3141,10 & 1040,44 & 953,27 & 1336,65 & 1259,11 & 94,20 \\ \text { Fundo } & 192,00 & 2790,86 & 984,79 & 990,04 & 1239,42 & 1100,16 & 88,76 \\ \text { Média } & 212,57 & 3215,91 & 997,45 & 1130,19 & & & \\ \text { Dv P } & 20,98 & 466,98 & 38,26 & 275,20 & & & \\ \text { CV } & 9,87 & 14,52 & 3,84 & 24,35 & & & \end{array}$

- Coeficiente de variação da concentração de clorofila $a$ entre os períodos estudados, na lagoa facultativa 2.

$\begin{array}{crrrrrrr} & \text { Média/out. } & \text { Média/inv. Média/prim. } & \text { Média/ver. } & \text { Média } & \text { Dv P } & \text { CV } \\ \text { Superf. } & 381,10 & 1975,65 & 916,62 & 740,57 & 1003,48 & 685,36 & 68,30 \\ \text { Meio } & 302,77 & 1818,46 & 832,88 & 399,16 & 838,32 & 692,91 & 82,65 \\ \text { Fundo } & 312,53 & 1709,54 & 855,03 & 466,68 & 835,95 & 625,53 & 74,83 \\ \text { Média } & 332,13 & 1834,55 & 868,18 & 535,47 & & & \\ \text { Dv P } & 42,69 & 133,78 & 43,39 & 180,80 & & & \\ \text { CV } & 12,85 & 7,29 & 5,00 & 33,76 & & & \end{array}$


APÊNDICE B - Correlações Estatísticas 
- Correlações entre as principais variáveis obtidas neste estudo no outono, na lagoa facultativa 1.

\begin{tabular}{lrrrrr}
\hline & \multicolumn{1}{c}{$T\left({ }^{\circ} \mathrm{C}\right)$} & Cond. & $p H$ & SS & Dens. \\
\hline$T\left({ }^{\circ} \mathrm{C}\right)$ & 1 & & & & \\
Cond. & 0,999998 & 1 & & & \\
PH & 0,996339 & 0,996186 & 1 & & \\
SS & $-0,28508$ & $-0,28338$ & $-0,36598$ & 1 & \\
Dens. & $-0,2978$ & $-0,29611$ & $-0,37833$ & 0,999912 & 1 \\
\hline
\end{tabular}

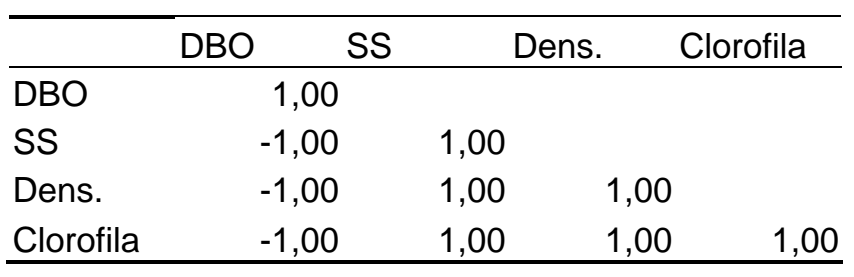

\begin{tabular}{lrrrr}
\hline & PT & NT & \multicolumn{2}{c}{ Dens. } \\
\hline PT & \multicolumn{1}{c}{1} & & \\
NT & $-0,10449$ & 1 & \\
Dens. & $-0,69184$ & 0,790389 & 1 \\
\hline
\end{tabular}

- Correlações entre as principais variáveis obtidas neste estudo no outono, na lagoa facultativa 2 .

\begin{tabular}{lrrrrr}
\hline & $T\left({ }^{\circ} \mathrm{C}\right)$ & Cond. & $\mathrm{pH}$ & SS & Dens. \\
\hline$T\left({ }^{\circ} \mathrm{C}\right)$ & 1 & & & & \\
Cond. & 0,680881 & 1 & & & \\
pH & 0,993475 & 0,75997 & 1 & & \\
SS & $-0,94833$ & $-0,87807$ & $-0,97833$ & 1 & \\
Dens. & 0,882385 & 0,945411 & 0,930292 & $-0,98608$ & 1 \\
\hline
\end{tabular}

\begin{tabular}{lrrrr}
\hline & DBO & SS & Dens. & Clorofila \\
\hline DBO & 1,00 & & & \\
SS & $-1,00$ & 1,00 & & \\
Dens. & 1,00 & $-1,00$ & 1,00 & \\
Clorofila & 1,00 & $-1,00$ & 1,00 & 1,00 \\
\hline
\end{tabular}

\begin{tabular}{lrrrr}
\hline & PT & NT & \multicolumn{2}{c}{ Dens. } \\
\hline PT & \multicolumn{1}{c}{1} & & \\
NT & -1 & 1 & \\
Dens. & $-0,96511$ & 0,965774 & 1 \\
\hline
\end{tabular}


- Correlações entre as principais variáveis obtidas neste estudo no inverno, na lagoa facultativa 1.

\begin{tabular}{lrrrrr}
\hline & \multicolumn{1}{c}{$T\left({ }^{\circ} \mathrm{C}\right)$} & Cond. & $p H$ & SS & Dens. \\
\hline$T\left({ }^{\circ} \mathrm{C}\right)$ & 1 & & & & \\
Cond. & $-0,93472$ & 1 & & & \\
pH & 0,93472 & -1 & 1 & & \\
SS & 0,912868 & $-0,70819$ & 0,708187 & 1 & \\
Dens. & $-0,76191$ & 0,942348 & $-0,94235$ & $-0,4311$ & 1 \\
\hline
\end{tabular}

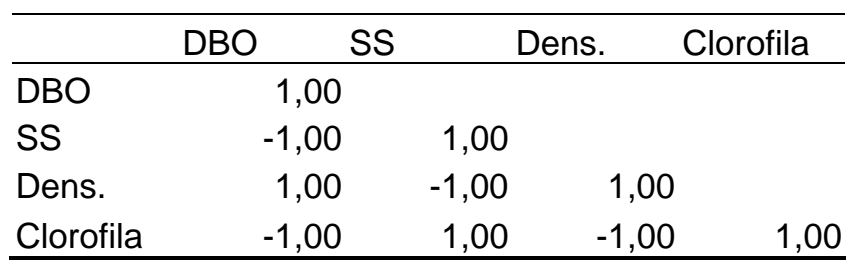

\begin{tabular}{|c|c|c|c|}
\hline & PT & NT & Dens. \\
\hline $\mathrm{PT}$ & 1 & & \\
\hline NT & 0,841512 & 1 & \\
\hline Dens. & $-0,07564$ & 0,475038 & \\
\hline
\end{tabular}

- Correlações entre as principais variáveis obtidas neste estudo no inverno, na lagoa facultativa 2 .

\begin{tabular}{lrrrrr}
\hline & \multicolumn{1}{c}{$T\left({ }^{\circ} \mathrm{C}\right)$} & Cond. & $\mathrm{pH}$ & SS & Dens. \\
\hline$T\left({ }^{\circ} \mathrm{C}\right)$ & 1 & & & & \\
Cond. & 0,960198 & 1 & & & \\
pH & 0,994782 & 0,983684 & 1 & & \\
SS & $-0,31493$ & $-0,56751$ & $-0,41012$ & 1 & \\
Dens. & 0,999911 & 0,963835 & 0,996054 & $-0,32755$ & 1 \\
\hline
\end{tabular}

\begin{tabular}{lrrrr}
\hline & DBO & SS & Dens. & Clorofila \\
\hline DBO & 1,00 & & & \\
SS & 1,00 & 1,00 & & \\
Dens. & $-1,00$ & $-1,00$ & 1,00 & \\
Clorofila & 1,00 & 1,00 & $-1,00$ & 1,00 \\
\hline
\end{tabular}

\begin{tabular}{lrrrr}
\hline & PT & NT & \multicolumn{2}{c}{ Dens. } \\
\hline PT & \multicolumn{2}{c}{1} & & \\
NT & 0,999999 & 1 & \\
Dens. & 0,627027 & 0,625956 & 1 \\
\hline
\end{tabular}


- Correlações entre as principais variáveis obtidas neste estudo na primavera, na lagoa facultativa 1 .

\begin{tabular}{lrrrrr}
\hline & $T\left({ }^{\circ} \mathrm{C}\right)$ & Cond. & $\mathrm{pH}$ & SS & Dens. \\
\hline$T\left({ }^{\circ} \mathrm{C}\right)$ & 1 & & & & \\
Cond. & -1 & 1 & & & \\
$\mathrm{pH}$ & $-0,5$ & 0,5 & 1 & & \\
SS & 1 & -1 & $-0,5$ & 1 & \\
Dens. & 0,967426 & $-0,96743$ & $-0,70295$ & 0,967426 & 1 \\
\hline
\end{tabular}

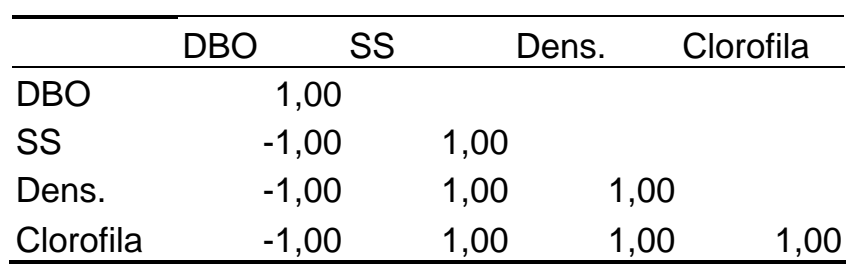

\begin{tabular}{lrrrr}
\hline & PT & NT & \multicolumn{2}{c}{ Dens. } \\
\hline PT & \multicolumn{2}{c}{1} & & \\
NT & 0,676056 & 1 & \\
Dens. & $-0,99998$ & $-0,68038$ & 1 \\
\hline
\end{tabular}

- Correlações entre as principais variáveis obtidas neste estudo na primavera, na lagoa facultativa 2 .

\begin{tabular}{lrrrrr}
\hline & \multicolumn{1}{c}{$T\left({ }^{\circ} \mathrm{C}\right)$} & Cond. & \multicolumn{1}{c}{$p H$} & SS & Dens. \\
\hline$T\left({ }^{\circ} \mathrm{C}\right)$ & 1 & & & & \\
Cond. & $-0,91766$ & 1 & & & \\
pH & $-0,80296$ & 0,5 & 1 & & \\
SS & 0,711203 & $-0,37331$ & $-0,99007$ & 1 & \\
Dens. & 0,400317 & $-0,00323$ & $-0,86763$ & 0,928908 & 1 \\
\hline
\end{tabular}

\begin{tabular}{|c|c|c|c|c|c|}
\hline & DBO & SS & & Dens.. & Clorofila \\
\hline DBO & & 1,00 & & & \\
\hline SS & & 1,00 & 1,00 & & \\
\hline Dens. & & $-1,00$ & $-1,00$ & 1,00 & \\
\hline Clorofila & & 1,00 & 1,00 & $-1,00$ & 1,00 \\
\hline
\end{tabular}

\begin{tabular}{lrrrr}
\hline & PT & NT & \multicolumn{2}{c}{ Dens. } \\
\hline PT & \multicolumn{2}{c}{1} & & \\
NT & $-0,52751$ & 1 & \\
Dens. & $-0,46699$ & 0,997567 & 1 \\
\hline
\end{tabular}


- Correlações entre as principais variáveis obtidas neste estudo no verão, na lagoa facultativa 1.

\begin{tabular}{lrrrrr}
\hline & \multicolumn{1}{c}{$T\left({ }^{\circ} \mathrm{C}\right)$} & Cond. & $p H$ & SS & Dens. \\
\hline$T\left({ }^{\circ} \mathrm{C}\right)$ & 1 & & & & \\
Cond. & 0,995875 & 1 & & & \\
pH & 0,97148 & 0,945958 & 1 & & \\
SS & 0,911367 & 0,870262 & 0,982973 & 1 & \\
Dens. & $-0,69852$ & $-0,63071$ & $-0,84828$ & $-0,93114$ & 1 \\
\hline
\end{tabular}

\begin{tabular}{|c|c|c|c|c|}
\hline & DBO & SS & Dens. & Clorofila \\
\hline DBO & & 1 & & \\
\hline SS & & -1 & 1 & \\
\hline Dens. & & 1 & -1 & 1 \\
\hline Clorofila & & -1 & 1 & -1 \\
\hline
\end{tabular}

\begin{tabular}{lrrrr}
\hline & PT & NT & \multicolumn{2}{c}{ Dens. } \\
\hline PT & \multicolumn{2}{c}{1} & & \\
NT & 0,999466 & 1 & \\
Dens. & $-0,41843$ & $-0,44787$ & 1 \\
\hline
\end{tabular}

- Correlações entre as principais variáveis obtidas neste estudo no verão, na lagoa facultativa 2.

\begin{tabular}{lrrrrr}
\hline & \multicolumn{1}{c}{$T\left({ }^{\circ} \mathrm{C}\right)$} & Cond. & $p H$ & SS & Dens. \\
\hline$T\left({ }^{\circ} \mathrm{C}\right)$ & 1 & & & & \\
Cond. & $-0,83698$ & 1 & & & \\
pH & 0,939671 & $-0,97368$ & 1 & & \\
SS & 0,666993 & $-0,15054$ & 0,371883 & 1 & \\
Dens. & $-0,97572$ & 0,936518 & $-0,99178$ & $-0,48761$ & 1 \\
\hline
\end{tabular}

\begin{tabular}{lrrrr}
\hline & DBO & SS & Dens. & Clorofila \\
\hline DBO & 1 & & & \\
SS & 1 & 1 & & \\
Dens. & -1 & -1 & 1 & \\
Clorofila & 1 & 1 & -1 & 1 \\
\hline
\end{tabular}

\begin{tabular}{lrrrr}
\hline & PT & NT & \multicolumn{2}{c}{ Dens. } \\
\hline PT & \multicolumn{2}{c}{1} & & \\
NT & 0,554946 & 1 & \\
Dens. & 0,325499 & 0,967218 & 1 \\
\hline
\end{tabular}

